UNIVERSIDADE DE SÃO PAULO

FACULDADE DE FILOSOFIA, LETRAS E CIÊNCIAS HUMANAS

DEPARTAMENTO DE SOCIOLOGIA

PROGRAMA DE PÓS-GRADUAÇÃO EM SOCIOLOGIA

THIAGO OCAMPOS ALVES

Entre o consentimento e a resistência:

o Sindicato dos Metalúrgicos de São José dos Campos em tempos de desregulamentação das leis trabalhistas.

Versão corrigida, o exemplar original se encontra disponível no CAPH (Centro de Apoio à Pesquisa Histórica) da FFLCH (Faculdade de Filosofia, Letras e Ciências Humanas).

SÃO PAULO 


\author{
UNIVERSIDADE DE SÃO PAULO \\ FACULDADE DE FILOSOFIA, LETRAS E CIÊNCIAS HUMANAS \\ DEPARTAMENTO DE SOCIOLOGIA \\ PROGRAMA DE PÓS-GRADUAÇÃO EM SOCIOLOGIA
}

\title{
Entre o consentimento e a resistência: \\ o Sindicato dos Metalúrgicos de São José dos Campos em tempos de desregulamentação das leis trabalhistas.
}

\section{Thiago Ocampos Alves}

Dissertação apresentada ao Programa de PósGraduação em Sociologia, do Departamento de Sociologia, da Faculdade de Filosofia, Letras e Ciências Humanas da Universidade de São Paulo, para obtenção do título de Mestre em Sociologia.

Orientador: Prof. Dr. Ruy Gomes Braga Neto

Versão corrigida, o exemplar original se encontra disponível no CAPH (Centro de Apoio à Pesquisa Histórica) da FFLCH (Faculdade de Filosofia, Letras e Ciências Humanas). Esta versão foi entregue sob a autorização do orientador Prof. Dr. Ruy Gomes Braga Neto, que se declara como de acordo com o procedimento: 
Dedico este trabalho a todos que vieram da periferia e mesmo com todas as dificuldades lutam diariamente por uma sociedade mais justa, livre e igualitária. 


\section{AGRADECIMENTOS}

Muitas pessoas colaboraram para a realização deste trabalho, de inúmeras maneiras, dedicando o seu tempo, esforço e compreensão para me auxiliar a superar as dificuldades que se apresentaram durante a realização da pesquisa. A quantidade de pessoas que foram importantes ao longo de todo esse percurso é grande, e agradeço a todos de uma maneira geral, pois sem o apoio direto dessas pessoas talvez não tivesse realizado nem mesmo a graduação.

Agradeço primeiramente, como não poderia deixar de ser, ao Professor Ruy Braga, que sempre esteve disposto a me auxiliar, apresentando novas perspectivas para o andamento da pesquisa, oferecendo uma orientação clara e rigorosa sobre os procedimentos necessários para a sua realização, com muita compreensão nos momentos de dificuldade que surgiram ao longo do percurso. Sou muito grato à disposição e o cuidado com que o Professor Ruy se dedicou ao meu trabalho.

Ao Professor Leonardo Mello e Silva, que com as nossas conversas e sugestões me forneceu vários elementos fundamentais para a compreensão das mudanças na legislação trabalhista e no mundo do trabalho como um todo. Agradeço à Professora Paula Marcelino pela leitura atenta do meu relatório de qualificação, com sugestões e críticas que foram imprescindíveis para a continuidade da pesquisa e sua finalização. Agradeço também ao professor Ricardo Musse, que desde a época da graduação me apresentou novos fundamentos e linhas teóricas para a compreensão da teoria sociológica, assim como, contribuiu de maneira importante na qualificação da pesquisa.

Não poderia deixar de agradecer à Professora Maria Helena Oliva Augusto, que realiza um sério e afetuoso trabalho de orientação com todos os ingressantes do Programa de Pós-Graduação em Sociologia, sempre atenta às nossas dificuldades e erros, procurando colaborar com discussões e sugestões para a realização de nossos trabalhos. Também agradeço aos meus colegas da disciplina de Pós-Graduação, Análise de Projeto I, realizada no primeiro semestre de 2010, na qual foi possível adquirir significativas contribuições para superar algumas dificuldades no percurso da pesquisa. Aos amigos que fiz no período do mestrado, Cleto Junior e Deni Rubbo, sou grato às diversas discussões que nos ajudaram mutuamente a compreender como se dá a trajetória de uma pesquisa, que consiste em superar nossas próprias limitações e obter avanços. 
Agradeço aos funcionários do Departamento de Pós-Graduação em Sociologia, Vicente Sedrângulo Filho e Maria Ângela Ferraro de Souza, pelo auxílio e boa disposição em sempre me assessorar nas minhas dificuldades técnicas e burocráticas. Agradeço ao CNPq, pelo auxílio através da concessão de bolsa para financiar esta pesquisa, essencial para a sua efetiva realização.

Aos meus entrevistados do Sindicato dos Metalúrgicos de São José dos Campos e Região, sou profundamente grato por terem me recebido tão bem, e terem se colocado à disposição para a realização das entrevistas. Sei que essas pessoas superaram as dificuldades de longas conversas em meio a uma rotina atribulada e outras tarefas que tinham que realizar, pois desejavam contribuir de maneira efetiva para a realização deste trabalho.

Agradeço à minha família, que sempre se manteve ao meu lado, mesmo com todas as dificuldades inerentes a uma família de baixa renda da periferia paulistana, me apoiando com todas as possibilidades que tinham a seu dispor. Meu profundo reconhecimento e gratidão à minha mãe Iara Aparecida Ocampos Alves e a meu pai José Cláudio Alves pela formação, carinho, apoio e todos os esforços que fizeram para que eu alcançasse os objetivos que almejava.

Ao meu grande amigo, a quem considero mais que um irmão, Raphael de Souza Ferreira, sou grato pela disposição com que me ajudou durante a realização desse trabalho, fornecendo apoio direto em momentos de dificuldade, o que foi fundamental para o seu prosseguimento e realização. À minha cunhada, Vivian Prado Fernandes, expresso minha sincera gratidão por seu apoio e disposição, realizando leituras cuidadosas e atentas, com apontamentos precisos, que foram fundamentais para a finalização dessa pesquisa.

Como não poderia deixar de ser, para quem me conhece e sabe da minha paixão, agradeço ao Sport Club Corinthians Paulista por momentos de grande emoção e satisfação que me foram proporcionados, fundamentais para aliviar as tensões provenientes da realização da pesquisa.

Para finalizar, agradeço à Amanda Prado de Oliveira, minha companheira, parceira com quem compartilho uma vida em comum, que com sua presença, carinho e amor fez com esse trabalho fosse possível. Sou extremamente grato por tudo. 
"Somos o que fazemos, mas somos, principalmente, o que fazemos para mudar o que somos."

(Eduardo Galeano) 


\section{RESUMO}

As mudanças ocorridas na década de 1990 no mundo trabalhista com a aplicação de Políticas Neoliberais no Brasil culminaram na desregulamentação da legislação do trabalho, influenciando a organização dos trabalhadores. A implementação de medidas que flexibilizam a legislação trabalhista cria novas táticas para a formação de um consentimento operário com a finalidade de garantir a flexibilização das relações trabalhistas e um crescimento da produtividade capitalista, com ganhos adicionais pela alteração das relações de trabalho. Este estudo tem como principal objetivo analisar como se estabelecem as relações entre as mudanças e o impacto e a apropriação que o Sindicato dos Metalúrgicos de São José dos Campos e Região tem das mesmas, nos últimos anos no Brasil. A pesquisa enfatizará a nova configuração da condição operária que transformou a forma tradicional de negociação salarial dos trabalhadores, modificando as reivindicações sindicais, a forma de participação operária nas empresas e etc.. As mudanças emergem acompanhadas de um processo de reestruturação produtiva visando o aumento da produtividade e seguindo a tendência mundial de perda coletiva de direitos, mas sua aplicação não se estabelece de maneira passiva; ela engendra novos códigos e táticas de negociação coletiva, além de diversas estratégias de resistência por parte dos trabalhadores. O Sindicato dos Metalúrgicos de São José dos Campos e Região como campo específico para a realização da pesquisa se justifica por se tratar este de um dos sindicatos pioneiros na resistência à aplicação das medidas que flexibilizam a legislação do trabalho no Brasil, além de localizar-se num dos pólos industriais e tecnológicos mais importantes do país. Por meio de entrevistas semi-estruturadas com os dirigentes sindicais o estudo procura compreender como ocorreu o processo de flexibilização das leis trabalhistas, as estratégias para a construção e conformação do consentimento operário por parte dos empresários e as resistências que o sindicato realiza diante do avanço patronal.

Palavras-chave: Desregulamentação da legislação trabalhista. Condição operária. Consentimento. Sindicalismo. Conflito social. 


\begin{abstract}
The changes occurred in the 1990's in the labor world with the application of Neo-liberal Policies in Brazil led to the deregulation of labor laws, affecting the organization of workers. The implementation of measures that make labor legislation more flexible creates new tactics for the formation of a workers' agreement in order to ensure the flexibility of labor relations and growth in capitalism productivity, with further gains by the change in labor relations. This study has as main objective to analyze how relationships are established within changes and the impact and the appropriation of Metalworkers Union of São José dos Campos and the surrounding region in the last years in Brazil. The research will highlight the new setting of labor conditions that have changed the traditional way of negotiating wages, modifying the union demands, the way workers participate in companies, etc. The changes emerge accompanied by a productive restructuring process aimed at increasing the productivity and following the global trend of collective loss of rights, but its application is not established in a passive way, it engenders new codes and tactics of collective negotiation, and several resistance strategies by workers. The Metalworkers Union of São José dos Campos and Region as a specific field for the making of this research is justified because it is one of the pioneers in the trade union resistance to implementing the measures that made labor legislation more flexible in Brazil, besides being located in one of the most important industrial and technological areas of the country. Through semi-structured interviews with union leaders the study seeks to understand how was the process of making the labor laws more flexible, the strategies to build and shape the worker's consent on the part of entrepreneurs and the resistance that the union hold against the employer's advance.
\end{abstract}

Keywords: Deregulation of the labor legislation. Working condition. Consent. Unionism. Social conflict. 


\section{LISTA DE ABREVIATURAS E SIGLAS}

ALCA - Aliança de Livre Comércio da América

APEOESP - Sindicato dos Professores do Ensino Oficial do Estado de São Paulo

AS - Articulação Sindical

CAT - Comunicação de Acidente de Trabalho

CIPA - Comissão Interna de Prevenção de Acidentes

CLT - Consolidação das Leis do Trabalho

CODEFAT - Conselho Deliberativo do Fundo de Amparo ao Trabalhador

CONCLAT - Congresso da Classe Trabalhadora

CQC - Círculo de Controle de Qualidade

CS - Convergência Socialista

CSP-Conlutas - Central Sindical e Popular - Coordenação Nacional de Lutas

CUT - Central Única dos Trabalhadores

DIEESE - Departamento Intersindical de Estatística e Estudos Sócio-Econômicos

DSS - Diálogo Semanal de Segurança

FAT - Fundo de Amparo ao Trabalhador

FEM - Federação Estadual dos Metalúrgicos da CUT

FGTS - Fundo de Garantia por Tempo de Serviço

FIESP - Federação das Indústrias do Estado de São Paulo

FMI - Fundo Monetário Internacional

GM - General Motors do Brasil

INCRA - Instituto Nacional de Colonização e Reforma Agrária

INPS - Instituto Nacional de Previdência Social

INSS - Instituto Nacional do Seguro Social

LER - Lesão por Esforço Repetitivo

MP - Medida Provisória

MST - Movimento dos Trabalhadores Sem-Terra

MTS - Movimento por uma Tendência Socialista

OPEP - Organização dos Países Exportadores de Petróleo

PDV - Programa de Desligamento Voluntário

PIB - Produto Interno Bruto 
PLR - Participação nos Lucros e Resultados

PMS - Programa de Metas Setorial

PSOL - Partido Socialismo e Liberdade

PSTU - Partido Socialista dos Trabalhadores Unificado

PT - Partido dos Trabalhadores

RJU - Regime Jurídico Único

SEBRAE - Serviço Brasileiro de Apoio às Micro e Pequenas Empresas

SENAI - Serviço Nacional de Aprendizagem Industrial

SENAT - Serviço Nacional de Aprendizagem do Transporte

SESC - Serviço Social do Comércio

SESI - Serviço Social da Indústria

SJC - São José dos Campos

TST - Tribunal Superior do Trabalho 


\section{SUMÁRIO}

Introdução.

Capítulo I - Condição operária e construção do consentimento............................... 17

1.1 A condição operária nos séculos XIX e XX......................................................... 17

1.2 A nova configuração da condição operária.......................................................... 31

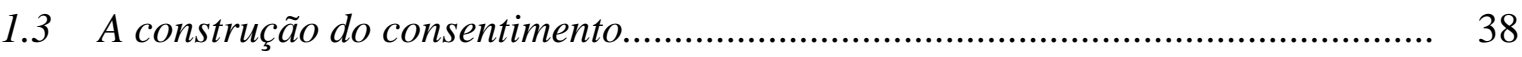

1.4 O consentimento na indústria..................................................................... 52

Capítulo II - As transformações no mundo do trabalho e o Sindicato dos 72 Metalúrgicos de São José dos Campos e Região.

2.1 Reestruturação produtiva e o movimento sindical............................................... 72

2.2 A Desregulamentação da legislação trabalhista no Brasil.................................. 89

2.3 Participação nos Lucros e Resultados e Banco de Horas..................................... 103

2.4 O Sindicato dos Metalúrgicos de São José dos Campos e Região......................... 115

Capítulo III - Consentimento e resistência no Sindicato dos Metalúrgicos de São

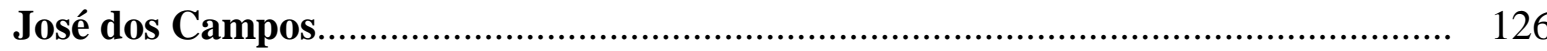

3.1 A desregulação da legislação trabalhista e o consentimento operário.................. 126

3.2 Resistências no Sindicato dos Metalúrgicos de São José dos Campos e Região... 136

3.2.1 Reestruturação produtiva, sistema capitalista e resistência...................... 137

3.2.2 Sindicato e a estrutura sindical............................................................... 138

3.2.3 Participação nos Lucros e Resultados (PLR)......................................... 141

3.2.4 Campanha contra o Banco de Horas....................................................... 148

3.2.5 Programa de Desligamento Voluntário (PDV), Contrato de Trabalho 154 por Tempo Determinado, Câmaras Setoriais, Terceirização e crítica á CUT........

Considerações Finais

Referências 165

Apêndice - Roteiro básico das entrevistas. 174 


\section{INTRODUÇÃO}

O incremento da reestruturação produtiva e da reforma trabalhista, a financeirização da Economia $^{1}$, a revolução informacional ${ }^{2}$, a reestruturação geográfica do trabalho, entre outras condições, provocam uma mudança bastante significativa na configuração da condição operária e, por conseguinte, na própria atuação dos operários.

Partindo desta premissa histórica, as mudanças que ocorreram na década de 1990 no mundo trabalhista com a aplicação de Políticas Neoliberais ${ }^{3}$ no Brasil culminaram na desregulamentação da legislação do trabalho, influenciando a organização dos trabalhadores. A implementação de medidas como, por exemplo, a Participação nos Lucros e Resultados (PLR) e o Banco de Horas, engendram novas táticas para a formação de um consentimento operário com a finalidade de garantir a flexibilização das relações trabalhistas e um crescimento da produtividade capitalista, com ganhos adicionais pela alteração das relações de trabalho. Estas medidas acabam por constituir relações trabalhistas mais instáveis, próximas do modelo liberal de contrato de trabalho, no qual o tratamento ao trabalhador é individualizado e distante da abordagem que contempla a categoria ao invés do indivíduo.

Nesse sentido, o objetivo principal desta pesquisa é analisar, por meio de entrevistas ${ }^{4}$ semi-estruturadas gravadas com os dirigentes do Sindicato dos Metalúrgicos de São José dos Campos e Região e fontes escritas próprias (como o caso do O Jornal do Metalúrgico e textos disponíveis no site do sindicato), como os trabalhadores se apropriam e agem diante das mudanças na legislação do trabalho e diante das diversas estratégias a que estão submetidos

\footnotetext{
1 A "financeirização" está intimamente ligada à mundialização dos processos produtivos. Neste sentido, a financeirização da Economia representa um crescimento exponencial da mundialização financeira para além das atividades produtivas, apresentando medidas desproporcionais entre capital financeiro e capital produtivo. A mundialização financeira ganha autonomia (acumulação à dominância financeira) influindo diretamente sobre as atividades produtivas. (Ver para mais detalhes: CHESNAIS, 1996; CHESNAIS, 1999; COUTROT, 2005).

2 (Ver para mais detalhes: LOJKINE, 1995; CASTELLS, 1999).

${ }^{3}$ Caracterizam-se Políticas Neoliberais as que têm por objetivo assegurar o poder e a renda das classes capitalistas a partir da redução dos gastos sociais do Estado, transferindo-os para o setor privado (o que não significa um Estado fraco, mas uma reconfiguração de suas atividades). São exemplos novas formas de gestão das empresas voltadas para os acionistas, políticas econômicas visando a estabilidade monetária e taxas de juros reais elevadas, a retirada dos controles estatais sobre a mobilidade do capital (liberalização dos fluxos do capital) e a flexibilização das relações trabalhistas (retirada de direitos trabalhistas) em busca de uma maior produtividade das empresas. (Ver para mais detalhes: DUMÉNIL \& LÉVY, 2004; BOITO JR., 1999).
}

${ }^{4}$ (Ver para mais detalhes: THIOLLENT, 1982; BEAUD \& PIALOUX, 2005; PIRES, 2008). 
para a construção do consentimento fabril. Busca-se, principalmente, a apropriação diferenciada pelo sindicato dessas mudanças na legislação e possíveis ações de resistência.

Os objetivos secundários compreendem analisar o impacto das mudanças na legislação do trabalho no Sindicato dos Metalúrgicos de São José dos Campos, seus ganhos e perdas no poder aquisitivo através das novas formas de remuneração, as novas formas de utilização da força de trabalho, a distribuição dos poderes interna à fábrica, o crescimento da concorrência entre os trabalhadores, o processo de naturalização das relações de produção como mais individualizante através da introdução de novas formas de remuneração supostamente ligadas ao desempenho pessoal, e a suposta desconstrução da identidade do grupo operário.

A análise, em suma, busca entender a nova configuração da condição operária a partir da desregulamentação das leis do trabalho. A PLR e o Banco de Horas são algumas dessas medidas da desregulamentação da legislação trabalhista que modificam o salário, a jornada de trabalho, o uso da força de trabalho, isto é, que desmantelam parte do aparato social do Estado. Essas medidas modificam a forma de negociação a que os trabalhadores estão acostumados, sua remuneração, seus benefícios, sua forma de luta, a pressão em que estão envolvidos, fazendo emergir novas relações no trabalho, auxiliando na conformação de um consentimento na fábrica e contribuindo para a configuração de uma nova condição operária com forma distinta de atuação interna à fábrica dos trabalhadores.

Abordar-se-á, especificamente, a implementação das medidas que flexibilizam a regulação do trabalho no Brasil nestas fábricas e a apropriação por parte do sindicato, as estratégias para construção do consentimento, os conflitos e resistências advindos dessa nova conjuntura, as novas pautas de negociação salarial, as novas organizações dos operários. Essas mudanças alteram uma série de relações que os trabalhadores mantinham antes, entre as quais a relativa estabilidade que os trabalhadores possuíam e que neste novo momento histórico aparece como privilégio para poucos. A concorrência entre coletivos de trabalho e entre os próprios trabalhadores, a individualização das relações trabalhistas e a fragmentação do grupo operário aparece como uma lógica fundamental para a conquista de patamares produtivos superiores pela empresa. Essas relações que emergem conformam a desestruturação parcial da classe operária, mas também estabelecem diversas transformações na atuação dos trabalhadores, incluindo diversas lutas e resistências que a pesquisa buscará indicar.

O Sindicato dos Metalúrgicos de São José dos Campos e Região é um campo privilegiado para a elucidação dos objetivos desta pesquisa, pois este, comparado a outros, 
proporciona algumas particularidades. Apresenta-se nas últimas décadas como um dos sindicatos mais resistentes às políticas neoliberais e às mudanças nas legislações trabalhistas, colocando-se como um dos mais progressistas e combativos do país, com ações efetivas de resistência (passeatas, protestos, greves, paralisações e etc.). É filiado a uma nova central sindical (CSP-Conlutas) que não possui ligações políticas com o governo federal, colocandose como independente e contrário ao sindicalismo que mantém uma relação cordial e harmônica com a patronal. A análise de um sindicato que pode ser designado como "politicamente de esquerda" e de atuação coerente com os seus princípios possibilita e fornece uma rica coleta de dados em relação às principais resistências estabelecidas contra as mudanças na legislação trabalhista, bem como permite determinar as principais táticas empregadas pelos empresários para a construção do consentimento nas fábricas. Apesar de uma tendência mundial de perda coletiva de direitos trabalhistas e sociais, algumas entidades, como é o caso do sindicato em foco, podem exercer uma resistência efetiva, que depende, dentre outros, de fatores como os correlacionados à existência de uma direção política atuante em defesa dos direitos dos trabalhadores, com respaldo e adesão da maior parte da categoria, dentro de uma conjuntura política e econômica favorável à atuação política como entidade.

Compreender como os operários lidam com a condição mutante da atual legislação trabalhista, tendo em vista os inúmeros impactos dessas alterações na forma tradicional de negociação salarial entre os trabalhadores e empresas, nas reivindicações sindicais, na participação dos operários nas fábricas, na distribuição interna dos poderes nas empresas, na divisão de tarefas, etc., contribui para a discussão em voga sobre a nova configuração da condição operária.

As principais limitações e dificuldades encontradas no decorrer da pesquisa dizem respeito ao foco proposto pela definição do Sindicato dos Metalúrgicos de São José dos Campos e Região como campo privilegiado de coleta de dados, principalmente por se tratar de um dos mais combativos sindicatos do país. Quando defrontadas com as mudanças das últimas décadas, não foi possível estabelecer generalizações sobre a atuação de operários, sindicatos e centrais sindicais no Brasil, já que o estudo se concentra na representação de um único sindicato. Algumas comparações foram baseadas em pesquisas anteriormente realizadas, o que limita o alcance de possíveis generalizações sobre a resistência operária no país. 
Outro ponto a ser considerado é o fato de o Sindicato dos Metalúrgicos de São José dos Campos e Região ser o principal campo desta pesquisa, de modo que os dados coletados representam os sindicalistas, explicitando sua atuação e interesses e não propriamente a dos trabalhadores, funcionários comuns das empresas, que poderiam tanto confirmar a atuação do sindicato ou apontar inconsistências e incoerências em seu discurso, caso houvesse. Por esse motivo também não foi possível saber ao certo como se dá a atuação dos operários no seu cotidiano, nem verificar se os trabalhadores adotam uma atuação correspondente ao que o sindicato indica.

Um estudo mais detalhado sobre a nova configuração da condição operária e a aplicação do consentimento teria que ter um acesso mais minucioso ao cotidiano do trabalhador, para verificar quais foram as mudanças que se estabeleceram nas últimas décadas, quais as estratégias que as empresas utilizam no seu dia-a-dia e qual a relação que o discurso dos empresários possui com os ideais de vida dos trabalhadores e das suas famílias. Assim seria possível verificar se há uma coalizão de interesses entre empresa e trabalhador, e caso houvesse, seria possível inclusive verificar se tal condição foi forjada/persuadida pela empresa, mesmo com as dificuldades enormes que uma pesquisa desse porte poderia apresentar.

Essa pesquisa abre possibilidades para uma confrontação e verificação futura a respeito da representação do sindicato e a percepção que o trabalhador comum tem da atuação do mesmo. Possibilita a realização de um estudo mais concentrado nos trabalhadores, amparado pela representação que o sindicato tem de várias questões pertinentes ao mundo do trabalho. Possibilita, ainda, futuras pesquisas para verificação da correspondência entre o discurso e as conquistas efetivas do sindicato, através de uma comparação mais detalhada com outros sindicados com princípios de atuação distintos e suas conquistas efetivas para os trabalhadores.

O principal avanço que a pesquisa alcançou foi fornecer a representação de um dos sindicatos mais combativos do país, com princípios claros de atuação sobre diversos temas em que a Sociologia do Trabalho se defronta em suas pesquisas. Permitiu-se a compreensão de uma lógica própria de atuação do sindicato e da central sindical correspondente, que são distintas (e em certa medida inovadoras) quando comparadas a atuação de sindicatos que mantêm políticas de conciliação com a patronal. Além disso, a pesquisa também fornece longos relatos sobre as tentativas de construção e conformação do consentimento nas fábricas 
representadas pelo sindicato, assim como o posicionamento e a atuação do mesmo diante das alterações no mundo do trabalho nos últimos anos.

O primeiro capítulo desta dissertação procura estabelecer a definição sobre a condição operária e as principais mudanças que o mundo do trabalho sofreu nas últimas décadas, com o objetivo de traçar as principais características sobre a nova configuração da condição operária. Buscou-se desenvolver e discutir o conceito de consentimento em Antonio Gramsci e em Michael Burawoy, particularmente, compreendendo a realização e a fabricação do consentimento na indústria.

No segundo capítulo descrevem-se as mudanças ocorridas no mundo do trabalho, a reestruturação produtiva, as transformações do sindicalismo, a desregulamentação trabalhista no mundo e principalmente no Brasil. Detalha-se principalmente a Participação nos Lucros e Resultados (PLR) e o Banco de Horas, assim como se analisa o Sindicato dos Metalúrgicos de São José dos Campos e Região, sua história, suas transformações e seu posicionamento frente às medidas que flexibilizam as leis trabalhistas.

No último capítulo estabelece-se a ligação entre as teorias que postulam uma nova configuração da condição operária e um consentimento fabril com a desregulamentação das leis trabalhistas. Também analisam-se as tentativas de construção e conformação do consentimento nas fábricas representadas pelo sindicato pesquisado, assim como, a atuação do mesmo frente às medidas que alteram a legislação trabalhista e a luta vitoriosa contra a aplicação do banco de horas na General Motors do Brasil.

Nas considerações finais, busca-se estabelecer uma discussão entre as tentativas de construção e conformação do consentimento nas fábricas que o sindicato pesquisado representa, bem como sua atuação diante dessas tentativas. As ações de resistência por parte deste mesmo sindicato buscam reafirmar e apresentar uma alternativa aos trabalhadores diante da aplicação de medidas da desregulamentação das leis trabalhistas. Embora sua efetividade e alcance dependam de vários fatores estruturais ou conjunturais da Política e da Economia no país, tais ações postulam uma perspectiva crítica aos "valores neoliberais". As atividades do sindicato e sua resistência às Politicas Neoliberais, portanto, figuram como uma alternativa e até mesmo um modelo a ser analisado por todos aqueles que procuram mudar ou resistir ao avanço do regime neoliberal. 


\section{Capítulo I - Condição operária e construção do consentimento}

\subsection{A condição operária nos séculos XIX e XX}

O debate ${ }^{5}$ a respeito da condição operária é fundamental para a compreensão das mudanças nas relações de trabalho no capitalismo neoliberal, assim como é essencial para as análises históricas das relações de trabalho no modo de produção capitalista. A nova configuração da condição operária é analisada e discutida pela Sociologia do Trabalho em conexão com as mudanças na organização e regulação do trabalho advindas das últimas décadas, a partir de 1980.

A análise da condição operária teve, historicamente, significativas contribuições de grandes autores ao longo dos séculos. Marx e Engels formularam e definiram a condição operária na década de 1840 como a condição de uma "massa" de homens, mais ou menos uniforme, com experiências similares, que são submetidos ao capital, obrigados a vender a sua força de trabalho como uma mercadoria. Os operários estavam submetidos às condições degradantes das moradias, à segregação espacial nas grandes cidades e a um trabalho precário, no qual não sentiam-se realizados pela sua atividade produtiva, num processo de estranhamento do mundo e de si mesmos que se efetiva através da sua relação com o trabalho capitalista. Mas o operário também é descrito pelos autores como um sujeito histórico com interesses específicos dentro da sociedade; ele representa o antagonismo à burguesia e por

\footnotetext{
${ }^{5}$ Os autores da Sociologia do Trabalho apresentam uma discussão frutífera das mudanças no mundo do trabalho, postulando as diferenças em relação ao modo de organização do trabalho fordista e demonstrando as conseqüências que a adoção dessas mudanças têm na sociedade atual. Autores como Mészáros, Mandel, Beaud \& Pialoux, Bourdieu, Chesnais e outros, apontam as consequiências negativas para os trabalhadores das mutações do capitalismo, que desenvolvem a degradação das condições sociais, a precarização das relações de trabalho, o aumento da concorrência entre os trabalhadores e entre coletivos de trabalho, a fragmentação da unidade de representação dos operários, um sentimento de desenraizamento em relação à classe operária, a individualização das relações de trabalho e a submissão mais sutil à lógica do capital, além de provocar um desemprego estrutural e etc. (ver para mais detalhes: MÉSZÁROS, 2007; MANDEL, 1982; BEAUD \& PIALOUX, 2009; BOURDIEU, 1987; CHESNAIS, 1996). Outros autores como Castells, Lazzarato \& Negri, Gorz e outros, apresentam aspectos positivos da nova configuração da condição operária para os trabalhadores, como a participação mais efetiva na concepção e planejamento das atividades dos trabalhadores, a perda da centralidade do trabalho fabril e repetitivo na sociedade das últimas décadas, o maior controle do processo produtivo pelos operários, a existência do trabalho em grupo, que permite uma interação das atividades dos trabalhadores, uma menor fragmentação entre as etapas do processo produtivo, uma ascensão do trabalho intelectual e uma queda do trabalho manual; os trabalhadores com uma participação mais acentuada nos lucros e decisões da empresa, o trabalho informacional que permite uma interação espacial e temporal avançada e etc. (ver para mais detalhes: CASTELLS, 1999; LAZZARATO \& NEGRI, 2001; GORZ, 2005).
} 
meio de movimentos e associações próprios expressam insatisfação, resistência e lutam para reverter a sua condição de explorados. São considerados protagonistas de uma nova ordem social que viria através da auto-emancipação dos trabalhadores.

Tem-se o intuito de analisar a condição operária partindo-se desta definição provisória em Marx e Engels, esperando com isso compreender as primeiras impressões que os autores tiveram do movimento operário, de suas condições de vida e de sua relação com o mundo do trabalho, ou seja, a forma como desenvolveram a representação da condição operária que surgiu logo após as mudanças que ocorreram com a Revolução Industrial ${ }^{6}$. Essa análise tem como objetivo verificar como os autores constroem e desenvolvem este conceito de condição operária naquele período, tendo em vista que o mesmo sofre variações ao longo de sua obra, principalmente devido à sua atuação política e seu desenvolvimento intelectual.

As variações do conceito destoam entre o caráter "passivo" e "ativo" do proletariado em relação ao mundo do trabalho. O caráter "passivo" é apresentado em suas obras de juventude como alienação do trabalho, no qual o proletariado é considerado uma classe alienada, semelhante à alienação religiosa de Feuerbach. A condição operária era analisada de forma abstrata, já que Marx sofria uma grande influência da filosofia alemã e não havia "descoberto" o proletariado na sua prática cotidiana. A influência de Feuerbach é nitidamente notada e o proletariado é considerado passivo. Marx afirma: "a filosofia é a cabeça dessa emancipação (do homem); o proletariado, o coração" (LÖWY, 2002:103). Em Feuerbach a cabeça é "ativa, espiritual, idealista, política, livre, e o coração que é passivo, sensível, materialista, social, sofredor e 'necessitado' (submetido às carências)" (LÖWY, 2002:103). A alienação deriva desta objetivação do trabalho em um produto, uma coisa, no qual as potencialidades humanas são exteriorizadas para esta coisa. No entanto, a alienação efetiva-se por meio da perda do objeto, da sua servidão ao objeto, em que o trabalho não tem a propriedade sobre o produto que fez, mas lhe parece alheio a si.

Já o caráter "ativo" da condição operária se estabeleceu a partir do contato de Marx com o socialismo francês e seus principais representantes oriundos do proletariado francês, principalmente a partir da sua participação nas sociedades secretas comunistas. $\mathrm{O}$ autor assinalou esse caráter ativo a partir da concentração do proletariado em grandes indústrias, de sua posição antagônica em relação à Burguesia, das moradias em vilas operárias com

\footnotetext{
${ }^{6}$ (Ver também para mais detalhes: THOMPSON, 1987; CASTEL, 1998)
} 
condições parecidas de degradação. Ou seja: compartilhamento de uma série de relações, que se tornam semelhantes aos seus participantes, inclusive com a possibilidade de criarem laços de pertencimento e solidariedade fundamentais para as revoltas contra a degradação das relações em que viviam, denotam esse caráter ativo.

O conceito de condição operária, portanto, atua de maneira dialética, em que o caráter "ativo" e "passivo" do proletariado é desenvolvido por Marx, sendo possível buscar relações e conexões na formulação da condição operária, que conta com grande contribuição de Engels, principalmente em seu livro A situação da Classe Operária na Inglaterra (1985).

O livro de Engels exerceu influência determinante sobre Marx, sendo um dos principais registros sobre a concepção de condição operária que Marx iria utilizar ao longo da vida, já que a descrição da condição operária é feita de modo detalhado e fruto de uma pesquisa aprofundada sobre as condições de vida da classe trabalhadora.

Engels procura traçar a condição operária a partir de um estudo detalhado sobre as condições de vida dos trabalhadores britânicos em 1844. Para o autor, a Revolução Industrial foi importante para a Inglaterra da mesma forma que a revolução política e a filosófica foram para a França e a Alemanha. Mas, o fruto mais importante dessa Revolução Industrial foi o proletariado inglês. Este nasceu com a introdução das máquinas e a expansão da indústria, que exigiu muitos homens para o trabalho. Como os salários subiram, houve "exércitos" de trabalhadores que emigraram das regiões rurais para as urbanas, a população cresceu e quase todo o crescimento veio da classe trabalhadora:

"A grande indústria acabou por transformar os utensílios em máquinas, e as oficinas em fábricas e deste modo, a classe média em proletariados, negociantes em industriais e a oposição fundamental e única passou a ser entre capitalistas e operários (...) O mesmo se passa fora do setor industrial, (...) o artesanato industrializou-se" (ENGELS, 1985: 26).

Os pequenos proprietários não podiam concorrer com os grandes proprietários. O proletariado não tinha a perspectiva de ascender à burguesia como a antiga classe média poderia fazê-lo; ele "estava em condições de agir agora de forma autônoma" (ENGELS, 1985: 26), devido sua posição e contradição perante os capitalistas.

Nas descrições realizadas por Engels os operários trabalhavam em grandes estabelecimentos industriais, habitavam juntos os cortiços, possuíam necessidades que originavam outras profissões a partir da demanda por vestimenta, alimentos, etc. Com isso 
migravam novas pessoas para viver junto com estes antigos operários. As vilas operárias transformavam-se em uma pequena e depois em uma grande cidade, uma vez que surgiam às vias férreas, as estradas, etc. Estabelecia-se um desenvolvimento rápido e espantoso das grandes cidades:

\footnotetext{
"Nas grandes cidades é que se demonstram mais claramente as conseqüências que o processo de industrialização exerce sobre o proletariado, foi na cidade que a centralização dos bens atingiu seu grau mais elevado, foi onde os costumes e as condições de vida anteriores foram mais radicalmente destruídos" (ENGELS, 1985: 33).
}

Em sua descrição havia, por toda parte, uma miséria indestrutível e uma guerra social. Os trabalhadores que encontravam um trabalho recebiam um salário que mal dava conta de mantê-los vivos. Já os trabalhadores que não encontravam trabalho tinham duas opções bem claras: roubar ou morrer de fome. A falta de alimentos provocava inúmeras doenças graves, provocando a morte de muitas pessoas.

Nas condições de habitação dos operários, suas construções eram quase sempre irregulares, tinham três ou quatro cômodos. "As ruas não são planas nem pavimentadas, são sujas, sem esgotos, sem canais de escoamento, a ventilação torna-se difícil pela confusa construção do bairro e pela quantidade de pessoas em um espaço pequeno, e o cheiro torna-se desagradável" (ENGELS, 1985: 38). As construções se deterioravam facilmente e os alimentos oferecidos nos mercados presentes nas imediações dos bairros eram quase sempre de má qualidade. As moradias eram, em alguns casos, em porões e frequentemente havia pessoas amontoadas em um único cômodo. Os operários destes bairros viviam nas condições mais miseráveis e precárias e embora tais condições não fossem da maioria do proletariado, qualquer operário poderia vivenciá-las

A segregação espacial dos operários foi realizada sem planos ou regulamentos por meio da especulação imobiliária das grandes ruas e dos bairros que eram redutos dos mais ricos. Para o autor, a indústria capitalista era a grande causadora dos problemas encontrados nas cidades industriais. A indústria fez com que trabalhador recém-liberto da servidão fosse utilizado de novo como simples material, como coisa, a ponto de habitar moradias que ninguém ocuparia.

A concorrência estava presente no ambiente dos trabalhadores e auxiliou no seu desenvolvimento, como Engels afirma: “A concorrência dos trabalhadores entre si, é o que há 
de pior nas condições de vida atuais do proletariado, é a grande arma da burguesia na luta contra o proletariado" (ENGELS, 1985: 94). Desta situação deriva o empenho dos trabalhadores para suprimir essa concorrência, associando-se e causando a fúria da Burguesia, que pretendia destruir estas organizações.

Todos os meios de existência da época descritos pelo autor eram de propriedade da Burguesia, amparados pelo poder do Estado. Como os trabalhadores dependiam destes meios para sobreviver, viviam em uma condição de dependência da Burguesia. A única liberdade que o proletariado tinha era submeter-se às condições da Burguesia, ou seja, vender a sua força de trabalho em troca de um salário que possibilitasse subsistir ou morrer de fome. E mesmo se alguns realmente morressem, de acordo com Engels apareceriam muitos outros para substituí-los.

Para Engels, a concorrência dos operários entre si é o que rebaixava seus salários, mas devido às qualificações que exigiam mais dos trabalhadores, principalmente na indústria, os salários eram maiores pelo próprio interesse da Burguesia. A maioria dos operários tinha que se sujeitar ao recebimento de um salário médio que mal lhe permitia a reprodução de sua existência. Aos desempregados nenhuma assistência era provida pelo Estado ou pela Burguesia.

O trabalhador viu-se obrigado a se vender e não sujeitar-se a um proprietário a vendê-lo, como era na época feudal. O operário possuía uma liberdade para garantir sua própria subsistência, o que antes lhe era concedido pelo seu proprietário. A Burguesia podia despedir quem quisesse no momento em que achasse necessário sem perder o investimento, que para eles era muito mais barato que um escravo. Não havia nenhum amparo jurídico e nem garantias aos trabalhadores que eram demitidos. Havia quase sempre uma população excedente, que fazia com que o salário fosse menor.

A maior parte das mercadorias eram produzidas e vendidas sem uma racionalidade quanto ao que deveria ser produzido e vendido para o mercado. Ao menor boato aumentavase ou diminuía-se as produções criando crises periódicas, que causavam mais desempregos aos trabalhadores e algumas falências aos capitalistas. Pelas análises do autor, foi assim sucessivamente: crise, prosperidade, crise, prosperidade, etc., em ciclos de cinco ou seis anos.

Em todos os períodos analisados havia sempre uma reserva de trabalhadores que estavam desempregados ou não eram utilizados diretamente na indústria. $\mathrm{O}$ autor designavaos como população excedente da Inglaterra; eram os trabalhadores de ganhos ocasionais, 
mendigos, pequenos ladrões, vendedores ambulantes e etc.. Os impostos ou taxas nas crises eram muito maiores para os pobres do que para os ricos. Para Engels, se os comerciantes não abrissem crédito aos desempregados e os trabalhadores não se ajudassem entre si, cada crise varreria multidões de desempregados que morreriam de fome.

Ainda de acordo com o autor, muitas vezes o ambiente de trabalho era promíscuo e muitas mulheres tinham que entregar-se ao industrial, já que, caso contrário, seriam demitidas. Havia também muitos acidentes com as máquinas de trabalho que frequentemente eram negligenciados pelos patrões. Isso tudo foi descrito pelos próprios relatórios de alguns burgueses. Muitos dos trabalhadores sofriam de alcoolismo. As doenças eram muito frequentes e a situação piorava devido à impossibilidade dos trabalhadores de obterem auxílio médico competente, causando também uma redução da expectativa de vida. A expectativa de vida e a mortalidade infantil eram muito maiores nos operários do que nas outras classes. $\mathrm{Na}$ educação os ricos estavam sempre na vantagem, não existia frequência escolar obrigatória, as escolas noturnas quase não tinham alunos e os jovens que lá estavam não conseguiam acompanhar as aulas devido sua dura jornada diária.

Os trabalhadores eram "condenados do trabalho". Trabalhavam por dinheiro, estavam forçados a isso. Na maior parte das vezes o trabalho se reduzia a um gesto mecânico, mesquinho, que deixava os trabalhadores mais "bestializados", pois era realizado por 12 horas ou mais. O trabalho tornava-se insignificante e extremamente monótono, um verdadeiro suplício. Mal deixava tempo livre para atividade intelectual, rebaixava o homem a uma condição semelhante à de um animal de carga, e para o autor, portanto, a única alternativa era resistir, lutar pela sua dignidade humana, lutando contra a Burguesia.

Apesar dessas condições precárias de vida para os trabalhadores, a Revolução Industrial produziu rapidamente nas grandes cidades a evolução da classe trabalhadora e a consciência de sua situação adquiriu importância social e política.

\footnotetext{
"As grandes cidades são os centros do movimento operário, foi aí que os trabalhadores começaram a refletir sobre a sua situação e a lutar, aí que apareceu mais claramente a oposição entre a burguesia e o proletariado" (ENGELS, 1985: 142).
}

Foi a partir desta contradição que, para Engels, se desenvolveram as associações operárias e o socialismo. As relações de servidão foram destruídas com o desenvolvimento da indústria e isso foi importante para a compreensão pelo proletariado da sua situação. $\mathrm{O}$ 
aumento da imigração, principalmente a irlandesa, fez com que a condição operária do inglês piorasse e as desigualdades aumentassem, favorecendo uma crise e a reflexão sobre a condição de sua classe por muitos operários. Como afirma o referido autor: "Os operários falam uma língua diferente, têm outras ideias e concepções, outros costumes e outros princípios morais, uma religião e uma política diferente da burguesia” (ENGELS, 1985: 144).

Havia um desprezo pela ordem social burguesa que se manifestava por meio do crime:

\footnotetext{
"Neste país rebentou a guerra social: cada qual se defende e luta por si contra todos, (...) cada um vê no outro um inimigo que é preciso afastar do caminho ou como muito um intermediário que é preciso explorar para seus próprios fins" (ENGELS, 1985: 152).
}

Essa guerra vai tomando traços de uma guerra entre proletariado e burguesia que se desenvolveu por causa do livre comércio.

As inovações técnicas fizeram do trabalho cada vez mais uma simples vigilância (que podia ser feita por uma criança ou mulher a preços muito reduzidos), o que consequentemente afastou muitos homens para nunca mais voltarem, ramos inteiros desapareceram ou foram transformados. "A única vantagem que as máquinas trouxeram aos trabalhadores é que elas lhes mostraram a necessidade de uma reforma social que fizesse trabalhar as máquinas não contra os operários, mas a seu favor” (ENGELS, 1985: 161).

A insatisfação era explicita para o autor. Os operários não podiam permanecer na condição de homens a não ser revoltando-se contra a burguesia. Sendo assim, "A primeira e mais brutal forma (...) foi o crime, a necessidade venceu o respeito à propriedade, começou o roubo" (ENGELS, 1985: 242), e este roubo aumentou com a expansão da indústria. Porém, os operários conscientizaram-se da ineficiência desse protesto contra a sociedade, principalmente pela pressão que a "opinião pública" tinha sobre os criminosos. Outra forma de resistência utilizada foi aquela dos proletários em relação às máquinas colocadas nas fábricas. As máquinas foram destruídas, mas esse tipo de resistência existiu apenas isoladamente, em alguns locais, e foi rapidamente revertida pela burguesia.

A partir de 1824, a permissão do parlamento britânico de livre associação dos operários inaugurou outra frente aberta para a luta. Antes já existiam associações clandestinas, que nunca conseguiram obter grandes resultados. Com a livre associação estas organizações tornaram-se poderosas nas lutas contra a burguesia, principalmente em greves e negociações 
salariais mais amplas, auxiliando os operários com dinheiro, se necessário. Em vários casos houve a tentativa de organizar os operários de uma única categoria em toda a Inglaterra e a de fundar, também naquele país, uma associação que reuniria vários setores em toda a Europa. Os meios que essas organizações empregavam para atingir seus fins eram as greves e paralisações que podiam ser parciais ou geral. Engels considerava que a realização de uma greve não era fácil, já que o trabalhador teria de suportar mais misérias, mas quando o objetivo do povo é preciso, acaba tendo-se a coragem necessária. A força da Burguesia residia na indecisão dos próprios operários.

A história dessas associações contém várias derrotas e em crises elas foram obrigadas a dissolver-se completamente. Na maior parte dos casos, os operários tinham que voltar ao trabalho por causa da fome. As greves eram muitas vezes ineficientes, mas eram um protesto contra as condições em que viviam os trabalhadores; eram a principal tentativa dos operários de abolir a concorrência entre si próprios. O princípio que os orientava era o de que o domínio da Burguesia se devia à concorrência dos operários entre si. Se eles parassem de se dividir, a dominação da Burguesia deixaria de existir. A necessidade faria com que se abolisse a concorrência, permitindo tornarem-se humanos e não coisas. Essas associações acabaram, ainda, por contribuir para alimentar o ódio e a acirramento dos operários contra as classes dominantes. Com isso:

\footnotetext{
"Há vários casos de tentativas de destruição e homicídios por parte dos proletários, o que demonstra que a guerra social é declarada e aberta. A burguesia tenta lutar contra essas organizações de toda forma. As greves são as escolas de combate que o proletariado prepara para o grande combate inevitável" (ENGELS, 1985: 253).
}

O cartismo tem início em 1835 como movimento em prol de melhores condições de vida para os operários, com um aspecto social de luta por bons salários, alimentação e redução da jornada de trabalho. Com seu desenvolvimento, a burguesia radical que estava presente no seu início foi se afastando, existindo vários momentos de alianças dessa mesma burguesia com o proletariado contra o governo conservador, mas logo depois a luta entre as duas classes voltou. Os cartistas diziam em palavra de ordem que "o nosso meio é o poder político: a nossa finalidade é a felicidade social" (ENGELS, 1985: 264). Com isso, "as características destrutivas do cartismo residem na sua orientação social, a identificação com o socialismo é inevitável" (ENGELS, 1985: 264). 
Engels considerava o movimento socialista inglês da época representado na figura de Owen e suas "comunidades", com direitos e educação iguais, divórcio, um governo racional, liberdade de opinião, etc.. Esse movimento de Owen, para o autor, justificava o estado de coisas atuais através do repúdio a qualquer tipo de ação que não fosse o da persuasão da opinião pública. Eles eram abstratos e pregavam a filantropia. Deste modo, o movimento operário estava dividido em dois: os cartistas e os socialistas;

“os Cartistas são mais atrasados, (...) mas são os mais autênticos representantes do proletariado (...) Os socialistas enxergam mais longe, propõem medidas práticas contra a miséria, mas saíram da burguesia (...) e são incapazes de se amalgamarem com a classe operária" (ENGELS, 1985: 266).

A fusão de socialismo com o cartismo para o autor já tinha se iniciado: "só quando estiver realizada, a classe operária será o verdadeiro líder intelectual da Inglaterra" (ENGELS, 1985: 266). Para o autor, os trabalhadores constituem "uma classe específica que possui interesses e princípios próprios e concepções particulares face a todos os possuidores, ao mesmo tempo que neles reside a força e a capacidade de desenvolvimento da nação" (ENGELS, 1985: 269).

Para Engels, a Burguesia é cínica, uma vez que detesta a influência do Estado nos negócios, mas precisa desse mesmo Estado para controlar o proletariado, usando-o neste sentido e procurando mantê-lo afastado no outro. Toda a legislação da época protegia quem tinha propriedade contra quem nada tinha, os juízes só interpretam a lei no sentido de quem as fez (eles próprios eram burgueses).

O autor considerava a condição operária insustentável e que logo essa situação levaria à revolução. Se a Burguesia não "despertasse" para as condições em que se encontrava o proletariado, eclodiria uma revolução, que nas palavras de Engels não teria comparação com nenhuma outra:

“A guerra dos pobres contra os ricos será a mais sangrenta que já existiu. (...) O preconceito de uma classe não se larga como quem deixa uma roupa velha. (...) A revolução tem de vir obrigatoriamente, já é muito tarde para encontrar uma solução pacífica para o conflito, (...) mas isso depende mais da evolução do proletariado do que da burguesia, (...) depende dos elementos socialistas e comunistas que ingressam na fileira do proletariado" (ENGELS, 1985: 331). 
Enquanto houver esta divisão entre os trabalhadores e a burguesia o ódio dos proletariados será justificado, e "será a alavanca poderosa do inicio do movimento operário" (ENGELS, 1985: 332).

A condição operária é desta forma, para o autor, uma condição de homens ligados conscientemente e organizados por uma situação semelhante de vida, com interesses comuns que não necessitam de um comando externo que lhes diga o que fazer; são conscientes de seus interesses históricos enquanto classe que representa os anseios da totalidade da sociedade, realizando com isso a auto-emancipação social.

É a partir dessa aposta em uma revolução dos operários que Engels influenciará a modificação do caráter passivo da condição operária em Marx para um caráter ativo, que foi vislumbrado quando da concentração do proletariado em grandes indústrias, do seu caráter antagônico em relação à Burguesia, em suas moradias em vilas operárias com condições semelhantes de degradação, ou seja, a partir do compartilhamento de uma série de relações, inclusive com a possibilidade de criarem laços de pertencimento e solidariedade fundamentais para as revoltas contra a degradação em que viviam.

O caráter ativo é expresso na possibilidade de ação dos operários enquanto classe social unida pelos seus interesses universais dentro da sociedade. As condições de vida em que se encontravam, detalhadamente descritas por Engels, são o retrato do que foi designado como condição operária, mas tal condição tem uma relação precisa com um determinado modelo de regime fabril de uma dada sociedade, que, como Burawoy analisa, influencia de modo decisivo nas atuações e condições a que o proletariado está submetido.

Segundo Burawoy, o processo produtivo contém elementos políticos e ideológicos, além daquele puramente econômico. A produção também inclui aparelhos políticos que reproduzem as relações de trabalho por meio da regulação dos conflitos fabris. O autor caracteriza esses aparelhos de regimes fabris e os conflitos associados a esses regimes de política de produção.

Burawoy considera o período em que Marx e Engels analisaram como despotismo de mercado. "Nesse regime, a regulação despótica do processo de trabalho é estabelecida pela coação econômica do mercado. A dependência dos trabalhadores em relação aos ganhos em dinheiro está inscrita na sua subordinação ao Licurgo fabril” (BURAWOY, 1990: 30). Este despotismo de mercado depende de três condições históricas especificas: 


\begin{abstract}
"Primeiro, os trabalhadores não têm outro meio de subsistência além da venda da sua força de trabalho em troca de salário. Segundo, o processo de trabalho é submetido à fragmentação e mecanização, de modo que a qualificação e o conhecimento especializado deixam de ser a base de poder. Dessa maneira, a separação sistemática entre trabalho mental e manual e a redução dos operários a apêndices das máquinas despojam-nos da capacidade de resistir à coerção arbitrária. Terceiro, impelidos pela concorrência, os capitalistas transformam seguidamente a produção através da extensão da jornada de trabalho, da sua intensificação e da introdução de novo maquinário. A anarquia do mercado conduz ao despotismo na fábrica." (BURAWOY, 1990: 30).
\end{abstract}

Ao passar dos anos, este período capitalista caracterizado como despotismo de mercado foi transformado. A condição operária obteve significativas mudanças advindas de implementações da legislação trabalhista, de modificações na organização do trabalho, da consolidação de uma representação dos interesses dos trabalhadores através de sindicatos, da adoção de melhorias sociais promovidas pelo Estado, diante de pressões de sindicatos e lutas sociais, que levaram a uma melhoria nas condições de vida e trabalho dos operários ${ }^{7}$.

Por volta da década de 1930 há a consolidação do regime de trabalho Taylorista nos Estados Unidos e nos países centrais da Europa. O Taylorismo aplicava a padronização das relações de trabalho através do controle e da sistematização do tempo para a realização das atividades produtivas, cada trabalhador deveria produzir uma atividade especifica no menor tempo possível. Estas características foram incorporadas pelo sistema Fordista, que consistia em milhares de operários trabalhando em linhas de montagem, em fábricas gigantescas com rígido controle de suas atividades, com uma forte hierarquia, uma divisão de tarefas e especialização funcional.

O regime de trabalho Fordista teve seu ápice após a Segunda Guerra Mundial no território estadunidense e em alguns países centrais da Europa, posteriormente se expandindo por muitos países periféricos. Este regime figurava com aumentos salariais à classe trabalhadora com interesse na expansão do consumo em massa e com uma estabilidade no emprego, em que os trabalhadores podiam permanecer a vida toda na mesma empresa. (ver para mais detalhes: GOUNET, 1999; AGLIETTA, 1979) O fordismo manteve-se relativamente estável entre o período de 1945 à 1973:

\footnotetext{
${ }^{7}$ (Ver para mais detalhes: BRAGA, 2003; WEIL, 1979; TELLES, 2006).
} 
“Ao longo desse período, os países capitalistas avançados alcançaram taxas fortes, mas relativamente estáveis de crescimento econômico. Os padrões de vida se elevaram, as tendências de crise foram contidas, a democracia de massa preservada e a ameaça de guerras intercapitalistas tornada remota. $\mathrm{O}$ fordismo se aliou firmemente ao Keynesianismo e o capitalismo se dedicou a um surto de expansões internacionalistas de alcance mundial que atraiu para a sua rede inúmeras nações descolonizadas" (HARVEY, 1992: 125).

Isto foi possível devido ao pacto social envolvendo governo, trabalhadores e empresas com a finalidade de estabilizar a acumulação de capital por meio dos ganhos de produtividade e dos estímulos ao consumo (AGLIETTA, 1979).

"O equilíbrio de poder, tenso, mas mesmo assim firme, que prevalecia entre o trabalho organizado, o grande capital corporativo e a nação-Estado, e que formou a base de poder de expansão de pós-guerra, não foi alcançado por acaso- resultou de anos de luta. (...) A derrota dos movimentos operários radicais que ressurgiram no período pós-guerra imediato, por exemplo, preparou o terreno político para os tipos de controle do trabalho e de compromisso que possibilitaram o fordismo" (HARVEY, 1992: 125).

O Estado neste período assumia uma variedade de obrigações:

“(...) $\mathrm{Na}$ medida em que a produção de massa, que envolvia pesados investimentos em capital fixo, requeria condições de demanda relativamente estáveis para ser lucrativa, o Estado se esforçava por controlar ciclos econômicos com uma combinação apropriada de políticas fiscais e monetárias no período pós-guerra. Essas políticas eram dirigidas para as áreas de investimento público - em setores como o transporte, os equipamentos públicos etc. - vitais para o crescimento da produção e do consumo de massa e que também garantiam um emprego relativamente pleno. Os governos também buscavam fornecer um forte complemento ao salário social com gastos de seguridade social, assistência médica, educação, habitação etc. Além disso, o poder estatal era exercido direta ou indiretamente sobre os acordos salariais e os direitos dos trabalhadores na produção" (HARVEY, 1992: 129).

A relação salarial consolida-se na maior parte dos países capitalistas e a condição operária torna-se mais ou menos estável, com a representação de seus interesses por meio de associações e sindicatos e uma legislação trabalhista que garantia nos países capitalistas avançados condições mínimas de vida (ver para mais detalhes: TELLES, 2006; BIANCHI \& BRAGA, 2008).

A compreensão sobre a periodização da produção capitalista para Burawoy se baseia na análise dos aparelhos políticos de produção, que são distintos e independentes do processo 
de trabalho. Para tal, concentra a sua análise a partir da dependência dos trabalhadores em relação à venda de sua força de trabalho. Após a queda do despotismo de mercado:

\begin{abstract}
“(...) as gerências não podem mais confiar exclusivamente na coação econômica do mercado, nem podem impor um despotismo arbitrário. Os operários devem ser persuadidos a cooperar. Os interesses dos trabalhadores devem ser coordenados com os do capital. Os regimes despóticos dos primeiros anos do capitalismo, nos quais prevalecia a coerção sobre o consentimento, têm que ser substituídos por regimes hegemônicos, em que o consenso predomina, embora não se exclua totalmente a coerção. Não é só que o recurso à coerção esteja limitado e regularizado; a própria aplicação da disciplina e da punição torna-se objeto de consentimento. (...) Na realidade, ela se determina pela dependência dos trabalhadores em relação ao emprego assalariado e pelo atrelamento deste último ao desempenho nos locais de trabalho. A previdência social reduz a primeira dependência; a legislação trabalhista limita a segunda" (BURAWOY, 1990: 32).
\end{abstract}

\title{
Segundo Burawoy:
}

"Se os regimes despóticos se baseiam na unidade entre a reprodução da força de trabalho e processo de produção e os hegemônicos em uma separação limitada, mas clara entre ambos, a natureza específica dos dois regimes varia segundo as formas do processo de trabalho, da concorrência entre as empresas e da intervenção estatal. Dessa maneira, a forma do regime despótico varia entre países de acordo com os seus padrões de proletarização (...) Os regimes hegemônicos também diferem de país para país de acordo com a extensão dos esquemas de previdência proporcionados pelo Estado e com a natureza da regulação estatal sobre os regimes fabris. (...) Apesar das grandes diferenças internas tanto aos regimes despóticos quanto aos hegemônicos, a base fundamental para a periodização permanece sendo a relação unidade/separação entre a reprodução da força de trabalho e a produção capitalista" (BURAWOY, 1990: 33).

O Estado e a intervenção estatal são variáveis explicativas para a existência de diferentes regimes hegemônicos para Burawoy, pois estabelecem o rompimento dos elos de ligação entre a reprodução da força de trabalho e a atividade produtiva no local de trabalho.

"Em primeiro lugar, a legislação previdenciária garante a reprodução da força de trabalho em um nível mínimo que independe da participação na produção. Além disso, esse sistema efetivamente estabelece um determinado mínimo de salário - que também pode ter vivência imposta pela lei -, o qual restringe o uso da remuneração por rendimento. (...) Em segundo lugar, o Estado limita diretamente os métodos de dominação gerencial que exploram a dependência salarial dos trabalhadores" (BURAWOY, 1990: 31). 
As intervenções estatais podem ser realizadas de diferentes formas e com consequências diversas nas sociedades capitalistas, Burawoy explicita por meio de duas formas diferentes, dois tipos de intervenções estatais. "O primeiro tipo de intervenção estatal separa a reprodução da força de trabalho do processo de produção, ao estabelecer níveis mínimos de assistência social a despeito do desempenho no trabalho. (...) O segundo tipo de intervenção estatal regula diretamente os aparelhos de produção" (BURAWOY, 1990: 40). Desse modo, o autor estabelece a relação do Estado com os aparelhos fabris:

\begin{abstract}
"Da mesma maneira, assim como o Estado fixa os limites aos aparelhos fabris, estes estabelecem limites sobre a forma das intervenções estatais. A um exame estático, não há maneira de conferir primazia a uma direção de determinação sobre a outra. Uma análise dinâmica, entretanto, sugere, (...) que a direção da determinação nasce do substrato das relações de produção. O desenvolvimento desigual e combinado do capitalismo - ou seja, a temporalidade e a natureza da justaposição de formas avançadas de capitalismo e de sociedades pré-capitalistas - conforma o equilíbrio das forças de classe na produção e determina limites às formas subsequentes de regime fabril e de suas relações com o Estado" (BURAWOY, 1990: 41).
\end{abstract}

Neste sentido as legislações trabalhistas são intervenções estatais que modificam e definem um regime fabril. As legislações trabalhistas ofereciam algo que os operários almejavam na época, uma estabilidade e segurança, já que impediam atos arbitrários e autoritários dentro do aparelho fabril. Mas ao mesmo tempo o capital conseguiu moldar a legislação para os seus interesses, já que esta permitia uma previsibilidade referente aos conflitos e negociações coletivas com os operários. Esta legislação permitiu ao mesmo tempo um aumento do poder aquisitivo dos trabalhadores e livrou o capital de uma possível crise de superprodução.

A condição operária começou a ganhar relevância no Brasil a partir do efetivo desenvolvimento da indústria na década de 1930, com a constituição de uma classe operária urbana que ao longo dos anos torna-se significativa, influenciando os rumos do país ${ }^{8}$. Com a Consolidação das Leis do Trabalho (CLT), sancionada em 1943, houve uma estabilização das relações trabalhistas e uma ascensão do movimento sindical como representante dos interesses dos trabalhadores assalariados. A adoção de muitos princípios do fordismo no Brasil se estabeleceu a partir do governo de Juscelino Kubistchek e, ligados ao Estado, os sindicatos

\footnotetext{
${ }^{8}$ (Ver para mais detalhes: LOPES, 1967).
} 
corporativistas formavam um dos elos da manutenção da "paz social" junto com o Capital. A condição operária no Brasil, por mais que apresentasse condições únicas e diferenciadas em relação aos países capitalistas avançados da época, possibilitou algumas conquistas na legislação aos trabalhadores e garantiu certa estabilidade à classe operária urbana, embora muito inferiores à condição operária apresentada nos países mais avançados do sistema capitalista 9 .

A condição operária sofreu ao longo dos períodos históricos modificações significativas, dependendo do regime fabril que era aplicado nos países capitalistas. De acordo com Burawoy, à época em que Marx e Engels analisaram a condição operária na Inglaterra, na metade do século XIX, o regime que prevalecia era o regime de despotismo de mercado, em que os trabalhadores estavam em constante insegurança em relação às suas condições de vida e de trabalho, sujeitos aos desmandos da política de produção, sofrendo com condições degradantes de existência. Com o passar dos anos, a condição operária obteve significativas conquistas para os trabalhadores, principalmente por meio das lutas sociais que os operários travaram para conquistar os seus direitos e melhores condições de vida e trabalho, proporcionadas na maior parte dos casos pelo Estado. Este regime era designado pelo autor como regime hegemônico e os trabalhadores garantiram certa estabilidade e segurança dentro dos países capitalistas.

A reprodução da força de trabalho é fundamental para a definição da condição operária, já que esta pode garantir aos trabalhadores a sua existência de forma relativamente independente do processo de produção. No período definido como despotismo de mercado havia uma unidade entre a reprodução da força de trabalho e o processo de produção. No caso do regime hegemônico havia uma separação da reprodução da força de trabalho e do processo de produção, o que garantia, em alguns casos nos países capitalistas avançados, a existência dos trabalhadores e os seus direitos resguardados pelo Estado. Este regime fabril sofreu alterações significativas a partir da década de 1970 nos países capitalistas avançados.

\subsection{A nova configuração da condição operária}

\footnotetext{
${ }^{9}$ (Ver para mais detalhes: LIPIETZ, 1988; FERREIRA, 1993; SILVA, 1991; NASCIMENTO, 1976).
} 
As mudanças no mundo do trabalho surgiram com as reformas neoliberais ${ }^{10}$ no final dos anos 70, implementadas pelos Estados Unidos e a Grã-Bretanha a partir de um desmantelamento do Estado de Bem Estar Social ${ }^{11}$, provocando uma profunda modificação na organização e regulação do mundo do trabalho ${ }^{12}$. Destaca-se o movimento de reestruturação produtiva em que o ajuste produtivo torna-se, a priori, uma dependência interna entre os operários, fazendo-os cobrar mais de si e dos outros, instituindo o salário por produtividade ligado às metas estabelecidas pela empresa, ao contrário do período taylorista/fordista. Com estas reformas irrompem diversas medidas no sentido de desregular os direitos trabalhistas e sociais, ao mesmo tempo em que a atividade sindical perde força.

\begin{abstract}
“A forte deflação de 1973-1975 indicou que as finanças do Estado estavam muito além dos recursos, criando uma profunda crise fiscal e de legitimação. (...) Ao mesmo tempo, as corporações viram-se com muita capacidade excedente inutilizável (principalmente fábricas e equipamentos ociosos) em condições de intensificação da competição. Isso as obrigou a entrar num período de racionalização, reestruturação e intensificação do controle do trabalho (caso pudessem superar ou cooptar o poder sindical). A mudança tecnológica, a automação, a busca de novas linhas de produto ou nichos de mercado, a dispersão geográfica para zonas de controle do trabalho mais fácil, as fusões e medidas para acelerar o tempo de giro do capital passaram ao primeiro plano das estratégias corporativas de sobrevivência em condições gerais de deflação" (HARVEY, 1992: 137).
\end{abstract}

A análise de Burawoy sobre o fim de um período do capitalismo, ou a mudança para um novo regime fabril, como já dito anteriormente, está intimamente ligada com a atuação do Estado:

${ }^{10}$ Da mesma forma que as Políticas Neoliberais já comentadas anteriormente, as reformas neoliberais caracterizam-se pelo objetivo de assegurar o poder e a renda das classes capitalistas a partir da redução dos gastos sociais do Estado, transferindo-os para o setor privado (o que não significa um Estado fraco, mas uma reconfiguração de suas atividades). São exemplos novas formas de gestão das empresas voltadas para os acionistas, políticas econômicas visando à estabilidade monetária e taxas de juros reais elevadas, a retirada dos controles estatais sobre a mobilidade do capital (liberalização dos fluxos do capital) e a flexibilização das relações trabalhistas (retirada de direitos trabalhistas) em busca de uma maior produtividade das empresas.

${ }^{11}$ De maneira resumida, trata de um modelo de governo no qual a iniciativa pública, por meio de aparelhos estatais, é fundamental não apenas nas esferas da segurança, saúde e educação, mas também quanto às políticas de emprego, previdenciárias e de renda da classe trabalhadora. O Estado possui o papel de agente essencial do desenvolvimento econômico, através de intervenções reguladoras nas políticas financeiras, comerciais e industriais, constituindo também empresas em pontos estratégicos das cadeias produtivas.

${ }^{12}$ (Ver para mais detalhes: BRAGA, 2006). 
“(...) na fase contemporânea, a lógica da acumulação capitalista em escala mundial torna a intervenção estatal menos relevante para a determinação das mudanças e variações na forma da política de produção. (...) O próprio êxito do regime hegemônico na limitação das iniciativas gerenciais e no estabelecimento de uma nova norma de consumo induz a uma crise de lucratividade. Em consequência, a gerência procura contornar ou sabotar a rigidez das normas do regime hegemônico e, ao mesmo tempo, incorporar as suas características que favorecem a cooperação operária" (BURAWOY, 1990: 33).

Essas mudanças estabelecem o inicio de um novo período no desenvolvimento do capitalismo para Harvey, designado como a Acumulação Flexível:

"A acumulação flexível, como vou chamá-la, é marcada por um confronto direto com a rigidez do fordismo. Ela se apóia na flexibilidade dos processos de trabalho, dos mercados de trabalho, dos produtos e padrões de consumo. Caracteriza-se pelo surgimento de setores de produção inteiramente novos, novas maneiras de fornecimento de serviços financeiros, novos mercados e, sobretudo, taxas altamente intensificadas de inovação comercial, tecnológica e organizacional. (...) envolve um novo movimento que chamarei de 'compressão do espaço-tempo' no mundo capitalista - os horizontes temporais da tomada de decisões privada e pública se estreitaram, enquanto a comunicação via satélite e a queda dos custos dos transportes possibilitaram cada vez mais a difusão imediata dessas decisões num espaço cada vez mais amplo e variado" (HARVEY, 1992: 140).

Conforme o processo de produção transforma-se, a reprodução da força de trabalho altera-se ao mesmo tempo, inclusive com modificações no consumo. A própria estética mais ou menos estável do modernismo fordista cedeu lugar à instabilidade e à uma estética pósmoderna que celebra a diferença, a efemeridade, o espetáculo, a moda e a mercantilização de formas culturais. O capitalismo desta nova fase, aparentemente desorganizado, se expressa de uma forma diversa do modelo fordista de regulação social, mas segundo Harvey há um novo tipo de organização:

\footnotetext{
"Porque o mais interessante na atual situação é a maneira como o capitalismo está se tornando cada vez mais organizado através da dispersão, da mobilidade geográfica e das respostas flexíveis nos mercados de trabalho, nos processos de trabalho e nos mercados de consumo, tudo isso acompanhado por pesadas doses de inovação tecnológica, de produto e institucional (HARVEY, 1992: 150).
} 
Os resquícios de trabalho estável oriundos do fordismo foram sendo destruídos com a mudança do capitalismo. Os locais de trabalho organizado foram transferidos e reconstruídos em regiões que careciam de tradições industriais anteriores, e nos centros mais antigos foi reincorporada a adoção das normas e práticas regressivas estabelecidas nessas novas áreas. A acumulação flexível implica níveis relativamente altos de desemprego "estrutural” (em oposição ao "conjuntural”), rápida destruição e reconstrução de habilidades, ganhos modestos (quando há) de salários reais e o desgaste, desconfiança e perda do poder sindical (uma das principais instituições políticas do regime fordista) ${ }^{13}$.

O mercado de trabalho passa por uma mudança significativa em relação ao período fordista:

\begin{abstract}
"O mercado de trabalho, por exemplo, passou por uma radical transformação. Diante da forte volatilidade do mercado, do aumento da competição e do estreitamento das margens de lucro, os patrões tiraram proveito do enfraquecimento do poder sindical e da grande quantidade de mão-de-obra excedente (desempregados ou subempregados) para impor regimes e contratos de trabalho mais flexíveis. É difícil esboçar um quadro geral claro, visto que o propósito dessa flexibilidade é satisfazer as necessidades com frequência muito específicas de cada empresa. Mesmo para os empregados regulares, sistemas como 'nove dias corridos' ou jornadas de trabalho que têm em média quarenta horas semanais ao longo do ano, mas obrigam o empregado a trabalhar bem mais em períodos de pico de demanda, compensando com menos horas em períodos de redução da demanda, vêm se tornando muito mais comuns. Mais importante do que isso é a aparente redução do emprego regular em favor do crescente uso do trabalho em tempo parcial, temporário ou subcontratado" (HARVEY, 1992: 143).
\end{abstract}

As mudanças nos empregos não criam resistência dos sindicatos como em muitos momentos do fordismo ocorreram, já que a flexibilidade em alguns poucos casos pode ser considerada mutuamente benéfica. Em relação aos efeitos gerais dessas transformações, estes não parecem positivos do ponto de vista dos trabalhadores como um todo, quando se consideram os níveis salariais, a estabilidade no emprego, a cobertura de seguro e os direitos de pensão.

Como foi relatado no trabalho etnográfico inovador realizado por Michel Pialoux e Stéphane Beaud na fábrica da Peugeot na França, O retorno à condição operária? (2009), em

\footnotetext{
13 (Ver para mais detalhes: SENNETT, 1999; BRAGA, 2006; SALLUM Jr., 2003, ANTUNES, 1995; LINHART, 2007).
} 
que se acompanharam as transformações na fábrica e as mudanças que o grupo operário sofreu ao longo de três décadas, os operários sofreram com as transformações no mundo do trabalho: perderam o enfoque que tinham obtido no período fordista, a sua representação política é constantemente negligenciada pelos grandes meios de comunicação e seu antigo poder sindical não garante mais aos trabalhadores a permanência de conquistas efetivas que foram alcançadas pela classe operária.

"Os porta-vozes dos operários (sindicatos operários, representantes de
fábrica, militantes associativos, o 'partido'), que tinham vocação para
representá-los no espaço público, perderam consideravelmente a sua
influência. A imagem que o grupo operário fazia de si mesmo tornou-se
opaca. Essa crise de representação contribuiu fortemente para a não
visibilidade do grupo. Digamos a cru: os operários, que tinham a seu favor a
força do número, aos poucos deixaram de meter medo e não assustam mais
os dirigentes. Trata-se aqui de uma ruptura importante na história das
relações de classe. Significa que os diques construídos ao longo dos anos
pelo movimento operário com o intuito de opor-se à exploração, de dotar o
grupo de uma consciência de classe e de resistir melhor à dominação
simbólica romperam-se largamente. Resultado: soberba, arrogância, e
diversas formas de menosprezo dos 'dominantes', durante anos refreadas
pela existência de uma cultura política operária (institucionalizada), foram
liberadas e hoje são muitas vezes exibidas sem complexos" (BEAUD \&
PIALOUX, 2009: 11).

Para Burawoy o mais significativo desta nova fase do capitalismo não são as tentativas de desmantelar as políticas sociais existentes, uma vez que tais tentativas têm resultados limitados. "Mais significativo para o desenvolvimento dos regimes fabris, na atualidade, é a vulnerabilidade coletiva dos trabalhadores à mobilidade nacional e internacional do capital; é essa vulnerabilidade que leva a um novo despotismo construído sobre os fundamentos do regime hegemônico" (BURAWOY, 1990: 32).

Um novo despotismo tem inicio a partir de uma série de mudanças que Burawoy analisa:

"Nas antigas atividades industriais como a automobilística, siderúrgica, elétrica e de borracha, a mudança no equilíbrio de classes está dando origem a um novo despotismo. Há dois conjuntos de condições particularmente responsáveis por essa nova ordem política no interior das fábricas. Primeiro, é agora muito mais fácil deslocar o capital de um lugar para outro, em virtude de três fenômenos: a geração de reservatórios de mão-de-obra barata nos países periféricos e nas regiões periféricas das sociedades do capitalismo avançado; a fragmentação do processo de trabalho de forma tal que diferentes componentes podem ser produzidos e montados em diferentes 
locais (às vezes com o simples apertar de um botão); e as transformações das indústrias de transportes e comunicações. Todas essas mudanças se ligam ao processo de acumulação de capital em escala internacional. Um segundo conjunto de mudanças localiza-se no interior dos próprios países de capitalismo avançado. O nascimento dos regimes hegemônicos, atrelando os interesses dos trabalhadores à sorte dos seus patrões, incorporando o poder da classe operária na fábrica, e não nos aparelhos de Estado, e o reforço do individualismo deixaram os operários indefesos diante dos desafios recentes do capital" (BURAWOY, 1990: 48).

Esse novo despotismo é designado como Despotismo Hegemônico pelo autor:

\begin{abstract}
"O novo despotismo ergue-se sobre a base do regime hegemônico que está substituindo. Ele é, de fato, um despotismo hegemônico. Os interesses do capital e do trabalho continuam sendo concretamente coordenados, mas onde o trabalho costumava receber concessões com base na expansão dos lucros, ele, agora, faz concessões com base na lucratividade relativa dos capitalistas entre si - isto é, dos custos de oportunidade do capital. (...) O novo despotismo não é a ressurreição do anterior; não é a tirania arbitrária do supervisor sobre operários individuais (embora isso também possa ocorrer) O novo despotismo é a tirania 'racional' da mobilidade do capital sobre o trabalhador coletivo. A reprodução da força de trabalho é novamente vinculada ao processo de produção, mas em vez de se dar pela via individual, a ligação se produz no nível da empresa, região ou mesmo nação. O medo de ser despedido é substituído pelo medo da fuga dos capitais, do fechamento das fábricas, da transferência das operações e do desinvestimento na planta industrial" (BURAWOY, 1990: 48).
\end{abstract}

A nova configuração da condição operária apresenta uma situação desfavorável para os trabalhadores que estão imersos em um regime fabril que já não postula a mesma estabilidade e segurança a que estavam submetidos no regime hegemônico. A concorrência entre os coletivos de trabalho e entre os próprios trabalhadores de uma empresa tornou-se algo presente no cotidiano operário; a fragmentação do coletivo operário representou um enfraquecimento significativo do poder sindical e as relações trabalhistas caracterizam-se cada vez mais por serem individualizadas, nas quais o contrato coletivo de trabalho por categoria apresenta-se como uma raridade para a totalidade dos trabalhadores.

No Brasil, a implementação de Políticas Neoliberais e as mudanças na produção tiveram seu início na década de 90. Com a premissa de "modernização" das relações, o Estado deixaria para a sociedade civil a resolução dos impasses entre Trabalho e Capital, o que 
confluía com os interesses do "Novo Sindicalismo" 14 que surgiu no final da década de 70, reivindicando maior autonomia dos sindicatos em relação ao Estado e uma participação mais ativa dos trabalhadores, diluindo a separação entre concepção e execução de suas atividades.

A luta para garantir que os sindicatos tivessem efetivo poder diante dos empresários, que pudessem estabelecer uma negociação direta com o empregador sem a ingerência do Estado, ou seja, para que deixassem de ser sindicatos corporativistas e com isso tivessem ganhos reais maiores foi uma reivindicação histórica do novo sindicalismo, mas ao mesmo tempo, caracterizou-se como uma medida que beneficiava - e em muitos casos continua beneficiando - os empresários, devido ao poder desigual que estes e os trabalhadores detinham naquela conjuntura. $\mathrm{O}$ poder dos sindicatos, que proporcionou significativas conquistas na década de 1970 e 1980, já não apresentava a mesma força na década de 1990, principalmente com a aplicação de medidas neoliberais no começo daquela década. Aumentou-se o desemprego estrutural no país, o que contribuiu para a existência de novas formas de contrato de trabalho mais flexíveis, culminando com a vulnerabilidade coletiva dos trabalhadores e a fragmentação do processo de trabalho, e resultando em uma transformação no equilíbrio entre as classes e favorecendo os empresários, ao contrário do objetivo inicial do novo sindicalismo, que acreditava que a negociação direta poderia trazer ganhos reais à grande maioria dos trabalhadores ${ }^{15}$.

Esta nova configuração da condição operária é consequência de uma modificação na organização e regulação do trabalho, com perda significativa do poder sindical e de conquistas coletivas dos trabalhadores. Ela apresenta condições distintas em relação ao que foi designado como regime hegemônico por Burawoy; particularmente, uma flexibilidade e insegurança em contraste com a relativa estabilidade que os trabalhadores no regime hegemônico conquistaram. No entanto, para o autor esta transformação não é fruto de aplicação da coerção sobre os trabalhadores, mesmo que isto tenha sido utilizado em diversos

\footnotetext{
${ }^{14}$ O "Novo Sindicalismo" surge ainda no período ditatorial, em oposição sindicalismo corporativo (que amparava sua atuação pela lei de sindicalização de 1931, que estabelecia um sindicato único por ramo produtivo e por região, além de garantir uma intervenção direta do Estado no funcionamento interno dos sindicatos e na regulação das relações entre Capital e Trabalho). O Novo Sindicalismo é a representação de uma nova postura do sindicalismo brasileiro mais próximo da ação direta, do confronto aberto com o Estado e com as empresas, em que a CUT (Central Única dos Trabalhadores) é a sua expressão máxima. (RODRIGUES, 1999; RODRIGUES, 2002).
}

${ }^{15}$ Ver para mais detalhes: CARDOSO, 2010; RODRIGUES, 1995; RODRIGUES, 1990). 
casos, mas sim de um processo de consentimento, construído com valores e ideias que foram, de alguma forma, apropriados pelos trabalhadores.

\subsection{A Construção do consentimento}

Antes de aprofundar propriamente o conceito de consentimento é necessário voltar aos conceitos principais de Gramsci (Estado Ampliado, sociedade civil, sociedade política e de hegemonia) e à concepção que o autor tem da sociedade capitalista.

A sociedade capitalista era compreendida por Gramsci como um Todo-Orgânico integrado, onde não era possível separar a base estrutural da sociedade da superestrutura correspondente a esta base ${ }^{16}$, nem separar as esferas político-ideológicas da esfera econômica. Essa separação só existiria enquanto uma separação metodológica, não havendo uma separação na realidade da sociedade.

A partir da Teoria do Estado Ampliado, o Estado para Gramsci é a soma da sociedade civil e da sociedade política. A sociedade civil compreende o conjunto dos aparelhos privados de construção da hegemonia, por meio dos quais se organiza o consenso e se concretiza a direção da sociedade. Fazem parte da sociedade civil, por exemplo, os meios de comunicação, as igrejas, as escolas, os partidos políticos, os sindicatos, etc. Já a sociedade política é o Estado em seu sentido restrito e representa o conjunto de aparelhos governativos. É a sede, na maior parte dos casos, da coerção, força e violência. É necessário ressaltar que a distinção entre as sociedades civil e política é analítica, uma vez que as mesmas não existem enquanto entidades separadas na prática. O conceito de Estado Ampliado expressa o alargamento do conceito de Estado na intenção de abarcar o complexo de atividades por meio das quais a classe dominante afirma sua soberania perante a sociedade.

O conceito de hegemonia em Gramsci pretende abarcar o complexo de atividades políticas, ideológicas e culturais que organizam a direção política sobre o conjunto da sociedade. A hegemonia é a dominação consentida de uma classe social sobre a outra e é distinta da pura dominação assentada na utilização da força. Para o autor, combina liderança (ou direção moral) com dominação. É exercida por meio do consentimento e da força, da

\footnotetext{
${ }^{16}$ No vocabulário marxista, a base estrutural corresponde à produção material das relações de produção de uma sociedade e a superestrutura corresponde à reprodução dessas relações nessa sociedade. Por exemplo, as relações econômicas pertencem à base estrutural e as relações jurídicas pertencem à superestrutura da sociedade. (Ver para mais detalhes: CASTEL, 1998; CASTILLO, 1996).
} 
imposição e da concessão, de e entre classes e blocos de classes e frações de classes. A hegemonia pode se estabelecer de forma ativa, como vontade coletiva, ou manifestar-se de forma passiva, por meio de um apoio disperso ao grupo dominante. Em um sentido mais preciso, a hegemonia define o horizonte ideológico de uma época.

A hegemonia também se apresenta como uma construção instável, sempre sujeita a alterações na sua correlação de forças, pois para toda hegemonia há restrições e pode haver o aparecimento de contra-hegemonia. Por isso, tem sempre que renovar-se (não necessariamente mudar) a cada período histórico, com concessões e coerções, porque o exercício do poder exclusivamente pela coerção, expressando-se de forma ditatorial e déspota, não reuniria o apoio necessário para sua sustentação, não fosse apenas por um breve período histórico (Ver para mais detalhes: OLIVEIRA et al, 2010). O que Gramsci afirma é que dominação pura e simples não basta para a consolidação e manutenção do poder. É necessária a concessão para a construção de valores comuns, tanto para dissimular e mascarar os conflitos de classe como para afirmar a classe dominante como legítima portadora dos direitos de comando da sociedade em questão. Nesse sentido, a classe dominante incorpora simbolicamente também as classes dominadas e estas se expressam no interior do ideal e do discurso dominante.

$\mathrm{Na}$ sociedade capitalista, a burguesia detém a hegemonia por meio da produção da ideologia e de valores que apresentam a ordem social vigente, que embora não perfeita, perfaz-se na melhor organização social possível. Quanto mais difundida a ideologia, tanto mais sólida a hegemonia e tanto menos se tem a necessidade do uso de violência explícita. A dominação não pode aparecer como dominação, e sim como uma realidade única, sem distinção de classes, de uma sociedade comum a todos, com valores pretensamente universais. Sob esse prisma, também nos aspectos culturais, na construção de valores e de idéias, Gramsci considera fundamental a luta política.

O campo cultural não é o único em que a hegemonia se expressa e se constrói. A economia, como esfera fundamental da sociedade, também exerce importância essencial na elaboração de Gramsci, pois ao mesmo tempo em que a hegemonia é política e ideológica ela também é econômica. Para que uma classe seja hegemônica não basta apenas ser dominante por meio do Estado, ela tem também que controlar a economia. Assim, as relações entre os campos da economia, do Estado e da sociedade civil são imbricadas, dinâmicas e dialéticas, influenciando e sendo influenciadas. A hegemonia permeia, então, todas as esferas citadas. 
Nesse contexto, o exercício da hegemonia pressupõe não só o uso da força como a construção de valores supostamente universais, estabelecendo o consenso na sociedade. A partir disso, o emprego maior ou menor da coerção ou do consenso será mediado pela conjuntura, em que as classes dominadas podem criar condições de desestabilizar as classes dominantes. Para Gramsci os órgãos de opinião pública (meios de comunicação, jornais e associações) têm papel fundamental nesse processo de construção do consenso, mesmo porque esses órgãos possuem a capacidade de disseminar e multiplicar os valores do consenso hegemônico. Assim, o autor estabelece significativa importância para a luta política, sobretudo na sociedade civil, na construção de valores antagônicos aos da classe que detém a hegemonia. A luta em busca da hegemonia deve articular-se em todos os níveis da sociedade: a base econômica, a superestrutura política e a superestrutura ideológica.

Gramsci foi o primeiro pensador a analisar as mudanças que ocorreram na sociedade estadunidense a partir da década de 1920, o que ele denominou em seu artigo "Americanismo e fordismo ${ }^{17 "}$ como um novo modo de vida que estava se estabelecendo naquela sociedade. Seu interesse com a análise era demonstrar a pertinência e importância da sociedade estadunidense, que estava surgindo naquele momento como alternativa em relação ao ciclo revolucionário europeu que se estabeleceu após a crise de 1929 e fez emergir regimes fascistas na Europa.

Analisando a mudança do eixo dinâmico-econômico da Europa para os Estados Unidos, o autor afirma que a mesma não está ligada somente à organização da economia que decorreu ao processo produtivo, mas liga-se, ao mesmo tempo, à uma modificação no modo de regulação do capitalismo nos Estados Unidos, o que significa alterações simultâneas abrangendo as esferas cultural, política e econômica. O americanismo combina a mudança no modelo de organização do trabalho com a adoção de princípios do taylorismo, aliada com a modificação no modelo de regulação do trabalho e no mecanismo global de acumulação do capital, a partir da implementação de princípios do fordismo. (Ver também para mais detalhes: AGLIETTA, 1979).

As análises realizadas no já mencionado artigo "Americanismo e fordismo" são fundamentais para a discussão sobre o consentimento, assim como permitem a inteligibilidade

\footnotetext{
${ }^{17}$ O artigo é referente ao Caderno 22, da coletânea de 29 cadernos escritos por Gramsci na prisão italiana, denominada no Brasil de Cadernos do Cárcere. Este artigo foi escrito em 1934 em meio à grande crise econômica que assolava o mundo e quando se convivia com medidas que buscavam a recuperação desta crise (tanto medidas fascistas como medidas "programáticas").
} 
sobre as condições necessárias para a aplicação do fordismo como modelo integrado de regulação e organização do trabalho e como mecanismo global de acumulação do capital. Assim, neste momento a pesquisa deter-se-á em uma compreensão mais profunda da análise que Gramsci realizou sobre as mudanças na condição operária e no modo de vida estadunidense, principalmente em razão das alterações fabricadas com o surgimento da grande indústria no final do século XIX.

No início de seu artigo Gramsci fornece uma definição provisória sobre este novo modo de vida que os Estados Unidos estão produzindo:

\begin{abstract}
"No geral pode-se dizer que o americanismo e o fordismo derivam da necessidade imanente de organizar uma economia programática e que os diversos problemas examinados deveriam ser os elos da cadeia que assinalam exatamente a passagem do velho individualismo econômico para a economia programática. Estes problemas surgem em virtude das diversas formas de resistência que o processo de desenvolvimento encontra em sua marcha, resistência provocada pelas dificuldades inerentes à societas rerum e à societas hominum" (GRAMSCI, 1990: 375)
\end{abstract}

A partir desta definição, que enfatiza a passagem do individualismo econômico para uma economia programática e as resistências advindas desta mudança, o autor procura explicar a diferença de condições que provocaram a existência desta nova organização do trabalho. Para Gramsci as mudanças que ocorriam nos Estados Unidos eram um avanço histórico em relação às condições em que se encontrava a sociedade européia, pois estas transformações eram capazes, na visão do autor, de comportar e promover o desenvolvimento das forças produtivas. A partir disso, ele defende a existência desse novo modo de regulação do capitalismo, particularmente para a superação da anacrônica estrutura social da Europa.

A situação dos Estados Unidos era distinta da enfrentada pelos europeus, o que permitia uma condição favorável para a aplicação de uma mudança na atividade produtiva, principalmente porque o capitalismo existente à época nos Estados Unidos tinha como diferencial o fato de que não ser limitado pelos resquícios sociais dos modos de produção anteriores, como acontecia com a Europa:

"A não-existência dessas sedimentações parasitárias, deixadas pelos períodos históricos passados, permitiu uma base sadia para a indústria, e especialmente para o comércio, e permite cada vez mais a redução da função econômica representada pelos transportes e pelo comércio a uma real atividade subalterna da produção, ou melhor, a tentativa de incorporar estas atividades à própria atividade produtiva" (GRAMSCI, 1990: 381). 
O Estado (principalmente o italiano, que Gramsci utiliza como exemplo de sua análise) também representa uma fonte de parasitismo significativo, devido a pensões e aposentadorias para funcionários públicos com pouco tempo de trabalho, ao contrário dos operários e camponeses. Essas características dificultam a aplicação de uma nova e mais competitiva organização do trabalho. A relação entre a população ativa e passiva na Itália é uma das mais desfavoráveis da Europa, como o autor afirma:

"A massa de população absolutamente parasitária é muito grande e exige para os seus serviços um contingente também grande de massa indiretamente parasitária; a massa 'semiparasitária' é assim definida porque multiplica de modo anormal e danoso atividades econômicas subordinadas, tais como o comércio e as atividades intermediarias em geral" (GRAMSCI, 1990: 380).

Com relação ao fordismo, as condições foram diferentes, o que permitiu a adequação da produção com experiências inovadoras, além de não utilizar somente a força para a mobilização dos trabalhadores:

\footnotetext{
"Recordar as experiências realizadas por Ford e a economia feita pela sua empresa através da gestão direta do transporte e do comércio da mercadoria produzida, economia que influi sobre o custo de produção, permitiu melhores salários e menores preços de venda. A existência dessas condições preliminares, racionalizadas pelo desenvolvimento histórico, tornou fácil racionalizar a produção e o trabalho, combinando habilmente a força (destruição do sindicalismo operário de base territorial) com a persuasão (altos salários, benefícios sociais diversos, propaganda ideológica e política habilíssima) para, finalmente, basear toda a vida do país na produção" (GRAMSCI, 1990: 381).
}

As condições favoráveis foram o aporte para a racionalização da produção. Gramsci afirma: "A hegemonia vem da fábrica e, para ser exercida, só necessita de uma quantidade mínima de intermediários profissionais da política e da ideologia" (GRAMSCI, 1990: 381). Nesta passagem é possível compreender a importância que o autor estabelece para as modificações realizadas nos Estados Unidos, em que a fábrica fomenta e expande as transformações como um todo, particularmente por meio da difusão ideológica, moral, cultural e política, favorecendo o aparecimento de um novo modo de vida. A hegemonia da burguesia nesta sociedade nasce da fábrica e expande-se por toda a sociedade, principalmente porque nos Estados Unidos não existem classes sem uma função social determinada no mundo produtivo. 
Segundo o autor, o fenômeno de massas é "simplesmente a forma desse tipo de sociedade 'racionalizada', na qual a 'estrutura' domina mais imediatamente as superestruturas, que são 'racionalizadas' (simplificadas e em menor número)" (GRAMSCI, 1990: 382). Para ele, o desenvolvimento da superestrutura na sociedade americana era considerado incipiente e simples em comparação às velhas superestruturas seculares da Europa.

Gramsci afirma, ainda, que há uma adaptação do trabalhador a essa nova estrutura industrial, que é proporcionada pelos altos salários. De acordo com ele, a questão da hegemonia não foi colocada em pauta justamente porque não houve o desenvolvimento da superestrutura de maneira semelhante a que é apresentada na Europa. A luta nos Estados Unidos se apresenta como uma luta entre a propriedade de oficio e a liberdade industrial, sendo os sindicatos representantes dessa expressão corporativa, o que garante um aspecto progressista à luta dos industriais e a dificuldade de uma construção homogênea da luta dos trabalhadores, por conta das misturas de culturas e a questão dos negros ${ }^{18}$.

Na Itália houve uma tentativa de implementar o fordismo, que logo foi esfacelado pelo avanço conservador. Naquele país os operários não se opuseram às inovações que diminuem os custos, mas mesmo assim o fordismo não obteve sucesso. Já nos Estados Unidos houve uma grande resistência que determinou a liquidação de parte significativa dos sindicatos livres e sua substituição por um sistema de organização sindical (que foi combatido vigorosamente pelos operários, porém eles foram derrotados). Outro fator importante é que na Itália o movimento corporativo não foi capaz de conseguir "as realizações jurídicas já verificadas que criaram as condições formais em que a transformação técnico-econômica pudesse realizar-se em larga escala" (GRAMSCI, 1990: 388). Além das formas jurídicas:

“A americanização exige um determinado ambiente, uma determinada
estrutura social (ou a vontade decidida de criá-la) e um determinado tipo de
Estado. O Estado é o Estado liberal, não no sentido do liberalismo
alfandegário ou da efetiva liberdade política, mas no sentido mais
fundamental da livre iniciativa e do individualismo econômico que alcança
através de meios próprios, como 'sociedade civil', através do próprio
desenvolvimento histórico, o regime da concentração industrial e do
monopólio. O desenvolvimento do tipo semi-feudal de acumulador de

${ }^{18}$ Nos Estados Unidos dessa época havia uma segregação institucionalizada de etnias diferentes, com privilegio e supremacia na legislação da "raça branca" em detrimento das outras "raças", o que dificultou a construção de uma identidade comum dos trabalhadores. 
capitais é, na Itália, uma das condições básicas para a transformação industrial (é, em parte, a própria transformação), e não uma conseqüência" (GRAMSCI, 1990: 388).

A orientação corporativa adotada na Itália, para Gramsci, atuou no sentido de preservar as posições das classes médias. Ao mesmo tempo em que preservava uma condição mínima de existência para muitos trabalhadores (evitando possíveis convulsões sociais se houvesse uma concorrência livre), preservou muitos desocupados das classes médias, mantendo um equilíbrio essencial para evitar catástrofes, mas também crescendo a um ritmo muito lento devido à dependência dos desocupados.

A questão da coerção é tratada pelo autor quando ele coloca em questão os instintos animalescos do homem e a indústria. Essa relação desenvolve-se de maneira conflituosa, na qual há um processo doloroso para o homem de sujeição de seus instintos à novos, rígidos e complexos hábitos e normas de ordem, precisão e exatidão que acompanham o desenvolvimento industrial. Essas mudanças foram implementadas por meio de coerção brutal, através do domínio de um grupo social sobre as forças produtivas. Neste sentido, a transformação da força de trabalho em trabalho propriamente dito, enquanto transformação da natureza em objetos úteis, foi marcada pela aplicação da força e da coerção sobre os impulsos animalescos dos homens.

No surgimento de novas formas de organização do trabalho ou no seu processo de desenvolvimento, crises estiveram presentes. Sobre esse aspecto, o autor afirma:

\footnotetext{
"Quando a pressão coercitiva é exercida sobre todo o complexo social (o que sucede especialmente depois da queda da escravidão e do advento do cristianismo), desenvolvem-se ideologias puritanas que moldam a forma exterior da persuasão e do consentimento ao uso intrínseco da força". (GRAMSCI, 1990: 393).
}

Essa pressão coercitiva veio acompanhada de ideologias, ao mesmo tempo em que também as moldava, o que contribuiu para a construção de um novo modo de vida. A construção da hegemonia, como já dito anteriormente, necessita dessa incorporação pela classe dominada de ideologias e discursos plausíveis sobre as mudanças. Com relação a esta situação histórica, Gramsci continua: “Efetivamente, estas massas ou já adquiriram os hábitos e costumes necessários aos novos sistemas de vida e de trabalho, ou então continuam a sentir a pressão coercitiva sobre as necessidades elementares da sua existência" (GRAMSCI, 1990: 394). 
A força e a coerção são utilizadas principalmente na crise do pós-guerra (1914-1918) com a aplicação dos princípios do taylorismo e a regulamentação sobre os corpos:

"A crise foi (e ainda é) mais violenta pelo fato de ter atingido todas as camadas da população e de ter entrado em conflito com as necessidades dos novos métodos de trabalho que vinham se afirmando (taylorismo e racionalização em geral). Estes novos métodos exigem uma rígida disciplina dos instintos sexuais (do sistema nervoso), um reforçamento da 'família' em sentido amplo (não desta ou daquela forma do sistema familiar), a regulamentação e a estabilidade das relações sexuais" (GRAMSCI, 1990: 394).

Neste caso, "pode-se criar uma situação de duplo fundo, um conflito intimo entre a ideologia 'verbal' que reconhece as novas necessidades e a prática real 'animalesca' que impede aos corpos físicos a absorção efetiva das novas atitudes” (GRAMSCI, 1990: 395).

Com relação ao problema da racionalização da produção e do trabalho, Gramsci dialoga com Trotsky, afirmando que este tinha uma vontade não-racional de dar supremacia à indústria nacional utilizando meios coercitivos externos, de impor "a disciplina e a ordem na produção, de adaptar os costumes à necessidade do trabalho" (GRAMSCI, 1990: 396). Havia um desequilíbrio entre teoria (correta quanto à necessidade do trabalho) e a prática (equivocada):

\footnotetext{
"O princípio da coerção, direta e indireta, na organização da produção e do trabalho, é justo, mas a forma que ele assumira era errada: o modelo militar tornara-se uma predição funesta, e os exércitos de trabalho faliram. (...) pois os novos métodos de trabalho estão indissoluvelmente ligados a um determinado modo de viver, de pensar e sentir a vida; não é possível obter êxito num campo sem obter resultados tangíveis no outro. Na América, a racionalização do trabalho e o proibicionismo estão indubitavelmente ligados: os inquéritos dos industriais sobre a vida intima dos operários, os serviços de inspeção criados por algumas empresas para controlar a 'moralidade' dos operários são necessidades do novo método do trabalho" (GRAMSCI, 1990: 396).
}

O sucesso da implementação de uma nova organização do trabalho depende, então, do exercício da coerção por meio de medidas advindas do método taylorista de organização do trabalho, aliado à persuasão e à construção de um consentimento que integre e faça a 
ligação com um novo modelo ideológico, que o complementa. Ou seja: faça os trabalhadores aceitarem, acreditarem e "viverem ${ }^{19}$ " essas mudanças.

O americanismo é "também o maior esforço coletivo realizado até agora para criar, com rapidez incrível e com uma consciência do fim jamais vista na História, um tipo novo de trabalhador e de homem" (GRAMSCI, 1990: 396). Gramsci demonstra sua assertiva recorrendo a Taylor e sua concepção do homem como "gorila domesticado":

"Efetivamente, Taylor exprime com cinismo brutal o objetivo da sociedade americana; desenvolver ao máximo, no trabalhador, as atitudes maquinais e automáticas, romper o velho nexo psicofísico do trabalho profissional qualificado, que exigia uma determinada participação ativa da inteligência, da fantasia, da iniciativa do trabalhador, e reduzir as operações produtivas apenas ao aspecto físico maquinal" (GRAMSCI, 1990: 397).

A mudança na organização do trabalho a partir dos princípios tayloristas, em que o trabalhador sofreu um processo de desqualificação, tem como contrapartida a adoção e incorporação de uma ideologia sobre como o trabalhador deve portar-se no trabalho e responder às exigências que aparecem cotidianamente em sua vida. Há, neste sentido, uma nova ideologia, que contempla um novo modo de vida e tem como princípio norteador algumas características do puritanismo.

\begin{abstract}
“As iniciativas 'puritanas' só têm o objetivo de conservar, fora do trabalho, um determinado equilíbrio psicofísico que impeça o colapso fisiológico do trabalhador, premido pelo novo método de produção. Este equilíbrio só pode ser externo e mecânico, mas poderá tornar-se interno se for proposto pelo próprio trabalhador, e não imposto de fora; se for proposto por uma nova forma de sociedade, com meios apropriados e originais" (GRAMSCI, 1990: 397).
\end{abstract}

Há, a partir disto, outro recurso muito significativo na discussão da implementação de uma ideologia que acompanhe as mudanças no setor produtivo da sociedade. Trata-se das remunerações de altos salários aos trabalhadores pela venda da sua força de trabalho:

"Ele (altos salários) é o instrumento para selecionar os trabalhadores mais aptos para o sistema de produção e de trabalho e para manter a sua

\footnotetext{
${ }^{19}$ Utiliza-se o termo "viverem" porque está envolvida uma adesão ideológica que vai além da aceitação e da crença, mas que envolve uma prática efetiva do trabalhador correspondente a essa nova moralidade, a qual adere e passa a viver.
} 
estabilidade. Mas o salário elevado é uma arma de dois gumes: é preciso que o trabalhador gaste 'racionalmente' a maior quantidade de dinheiro, para manter, renovar e, possivelmente, aumentar a sua eficiência muscular nervosa, e não para destruí-la ou diminuí-la. Eis então a luta contra o álcool, o mais perigoso agente de destruição das forças de trabalho, a se tornar função do Estado" (GRAMSCI, 1990: 398).

Neste contexto, é significativa para Gramsci a tentativa de interferência de Ford na moralidade dos seus empregados, principalmente em relação ao problema sexual. O fenômeno americano apresenta uma característica sui generis para o autor, que é a tendência à separação entre a moralidade-costume dos trabalhadores e a moralidade-costume das outras camadas da população. O novo modelo industrial prefere também a monogamia, já que trabalhadores que saem e se divertem a noite não são considerados bons empregados, não realizam suas funções de maneira exemplar, havendo nisto ligação com o controle de seus movimentos e de seus corpos.

O processo de mecanização e o taylorismo são expressos pelo autor por meio da análise das tarefas dos operários: "caminha-se automaticamente e, ao mesmo tempo, pode-se pensar em tudo aquilo que se deseja” (GRAMSCI, 1990: 404). O autor afirma:

\footnotetext{
"Os industriais norte-americanos compreenderam muito bem esta dialética inerente aos novos métodos industriais. Compreenderam que 'gorila domesticado' é apenas uma frase, que o operário continua 'infelizmente' homem e, inclusive, que ele, durante o trabalho, pensa demais ou, pelo menos, tem muito mais possibilidade de pensar, principalmente depois de ter superado a crise de adaptação. Ele não só pensa, mas o fato de que o trabalho não lhe dá satisfações imediatas, quando compreende que se pretende transformá-lo num gorila domesticado, pode levá-lo a um curso de pensamentos pouco conformistas. A existência desta preocupação entre os industriais é comprovada por toda uma série de cautelas e iniciativas 'educativas', que se encontram nos livros de Ford e de Philip". (GRAMSCI, 1990: 404).
}

Para Gramsci o fordismo não conseguiu e não conseguirá criar esse "gorila amestrado", como vinham afirmando alguns autores do período. De fato, essas iniciativas dos industriais para "educar e moralizar" os operários são um esforço na direção de evitar os tumultos e revoltas provenientes de um trabalho que não satisfaz os homens, que quer transformá-los em simples apêndices das máquinas e que afastou cada vez mais do trabalho humano a concepção da execução de um determinado objeto. A passividade do proletariado desejada pelos industriais, como já entendido pelos mesmos, não virá pela implementação 
imediata dos princípios do taylorismo, mas sim pela persuasão dos operários e a difusão de ideologias que complementam a aplicação destes princípios.

A forma dos altos salários é mais vantajosa no americanismo, mesmo quando considerada uma retribuição transitória, já que para o autor a "adaptação aos novos métodos de produção e de trabalho não se pode verificar apenas através da coação social" (GRAMSCI, 1990: 404):

\begin{abstract}
"Se a situação fosse normal, o aparelho de coerção necessário para obter o resultado desejado custaria mais do que os altos salários. Por isso a coerção deve ser sabidamente combinada com a persuasão e o consentimento, e isto pode ser obtido, nas formas adequadas de uma determinada sociedade, por uma maior retribuição que permita um determinado nível de vida, capaz de manter e reintegrar as forças desgastadas pelo novo tipo de trabalho. Mas, logo que os novos métodos de trabalho e de produção se generalizarem e difundirem, logo que o tipo novo de operário for criado universalmente e o aparelho de produção material se aperfeiçoar mais ainda, o turnover excessivo será automaticamente limitado pelo desemprego em larga escala, e os altos salários desaparecerão. Na realidade, a indústria americana que paga altos salários desfruta ainda do monopólio que lhe foi proporcionado pela primazia na implantação dos novos métodos; aos lucros de monopólio correspondem salários de monopólio. Mas o monopólio será, necessariamente, primeiro limitado e, em seguida, destruído pela difusão dos novos métodos tanto dentro dos Estados Unidos como fora (...) e desse modo desaparecerão os lucros elevados, e também os altos salários. Além do mais, sabe-se que os altos salários estão ligados a uma aristocracia operária e não são pagos a todos os trabalhadores norte americanos." (GRAMSCI, 1990: 405).
\end{abstract}

A construção do consentimento é realizada conforme as condições de uma determinada sociedade; quando a coerção não tem uma relação complementar com o consentimento torna-se ineficaz ao longo do tempo. A remuneração de altos salários gozados pelos operários de Ford é uma medida que favoreceu a persuasão e o consentimento dos operários, porém existem limitações para a sua prática, que se encontram justamente na sua expansão econômica para outras regiões e nas possibilidades de lucros dos industriais. Desta maneira, a medida adotada por Ford em suas fábricas tem como objetivo envolver e comprometer os operários em um novo modo de organização do trabalho, um novo "modo de vida" em proveito próprio, e quando cessarem os benefícios da adoção dessas medidas, Ford não logrará retirá-las e adotar medidas diversas que possam ter a mesma efetividade, ocasião em que utilizará, em alguns casos, aparelhos coercitivos de modo mais constante. 
Nas fábricas de Ford há uma grande instabilidade em comparação às outras indústrias, especialmente devido aos grandes prejuízos à saúde do trabalhador e ao grau de qualificação em que o mesmo é exigido na empresa:

"A indústria Ford exige uma discriminação, uma qualificação, para seus operários que as outras indústrias ainda não exigem; um tipo de qualificação diferente, nova, uma forma de consumo de força de trabalho e uma quantidade de força consumida ao mesmo tempo médio mais oneroso e extenuante do que em outras empresas, força que o salário não consegue reconstituir em todos os casos, nas condições determinadas pela sociedade." (GRAMSCI, 1990: 406).

Coloca-se para Gramsci o problema: este tipo de organização do trabalho é racional e deve se generalizar ou deve ser combatido pelos sindicatos, devido seu caráter degradante:

\begin{abstract}
"Em outras palavras, se é possível através da pressão material e moral da sociedade e do Estado, levar os operários como massa a sofrer todo o processo de transformação psicofísico para fazer com que o tipo médio do operário da Ford se transforme no tipo médio do operário moderno, ou se isto é impossível porque levaria à degradação física e a deterioração da raça, destruindo todas as forças do trabalho. Parece ser possível responder que o método Ford é 'racional', isto é, deve-se generalizar; mas para que isto ocorra faz-se necessário um longo processo, no qual se verifiquem mudanças nas condições sociais e nos costumes e hábitos individuais. Entretanto, as mudanças não podem realizar-se apenas através da 'coerção', mas só através da combinação da coação (autodisciplina) com a persuasão, inclusive sob a forma de altos salários, isto é, de possibilidades de melhorar o nível de vida; ou melhor, mais exatamente, de possibilidades de alcançar o nível de vida adequado aos novos modos de produção e de trabalho, que exigem um dispêndio particular de energias musculares e nervosas" (GRAMSCI, 1990: 406).
\end{abstract}

Os altos salários recebidos pelos trabalhadores fazem parte da realização das novas satisfações que estão emergindo com este novo modo de vida, e das exigências que ela cria para o trabalhador reproduzir a força de trabalho. A remuneração de altos salários está intimamente ligada, e reforça, a ideologia do progresso individual em que a sociedade estadunidense acreditava (em função principalmente do puritanismo), já que tal remuneração permite ao trabalhador um consumo superior ao considerado somente necessário para a reprodução da força do trabalho. A retribuição de altos salários para os operários provoca a estruturação de um determinado mercado consumidor que se organiza a partir da transferência de parte dos ganhos com produtividade na indústria para os salários dos trabalhadores. Gramsci foi um dos primeiros autores que analisou o compromisso estabelecido entre 
capitalistas e trabalhadores a partir da remuneração de altos salários pela venda da força do trabalho, compromisso esse capaz de pacificar os conflitos operários provenientes das linhas de montagem.

Quando há a constituição de um grupo adaptado, ele não só recebe o salário de monopólio como raramente é demitido, uma vez que seria contra os princípios econômicos a reorganização de um novo grupo com novos elementos que têm de se adaptar. Isto representa um limite ao exército de reserva e é a origem de aristocracias privilegiadas.

O Estado capitalista pode ter uma relação diferenciada com o modelo fordista, em comparação a atuação que este tem na Europa: "Efetivamente, não se trata só de conservar o aparelho produtivo existente,
num determinado momento; trata-se de reorganizá-lo para desenvolvê-lo
paralelamente ao aumento da população e das necessidades coletivas.
Exatamente neste desenvolvimento, no qual se localiza o maior risco da
iniciativa privada, é que deveria verificar-se uma maior intervenção do
Estado, que também não está à margem de riscos, muito ao contrário"
(GRAMSCI, 1990: 409).

Para Gramsci esse novo modo de organização e regulação do trabalho vai expandirse e tornar-se referência na Europa; para ele essa transformação já está em curso e será a vitória sobre os modelos arcaicos de organização e regulação do trabalho. "Em outras palavras: está verificando-se uma transformação das bases materiais da civilização européia, o que a longo prazo (...) levará a uma mudança da forma de civilização existente e ao nascimento forçado de uma nova civilização" (GRAMSCI, 1990: 411).

Neste processo de mudança em curso, não cabe para o autor tentar voltar às velhas formas coletivas de ação, mesmo que haja diversos aspectos dessas mudanças que afetem negativamente a maior parte dos operários, mas sim encontrar as possibilidades que esse novo modelo de organização e regulação do trabalho abre para os trabalhadores:

“O que hoje se conhece como 'americanismo' é, em grande parte, a crítica preventiva das velhas camadas que serão esmagadas pela nova ordem e que já foram atingidas por uma onda de pânico social, de dissolução e desespero; é uma tentativa de reação inconsciente de quem é impotente para reconstruir e insiste sobre os aspectos negativos da mudança. Não se pode esperar que a reconstrução seja iniciada pelos grupos sociais 'condenados', mas sim por aqueles que estão criando, por imposição e através do próprio sofrimento, as bases materiais desta nova ordem. Eles 'devem' encontrar o sistema de vida 'original', e não de marca americana, para transformar em 'liberdade' o que hoje é 'necessidade' (...) O americanismo, compreendido não só como vida 
de café, mas também como ideologia do Rotary Clube, não é um novo tipo de civilização: trata-se apenas de um prolongamento orgânico e de uma intensificação da civilização européia, que adquiriu uma nova pele no clima americano" (GRAMSCI, 1990: 412).

O texto estabelece uma relação direta entre o fordismo (enquanto organização do trabalho que emprega os princípios do taylorismo) e o americanismo (como forma ideológica e cultural de progresso individual), que são responsáveis pela constituição de um novo modo de vida. Para Gramsci não é possível desenvolver uma relação sem a presença da outra, ou seja, não é possível existir o americanismo sem a complementação econômica do fordismo, assim como não é possível obter resultados satisfatórios para a sociedade como um todo se existir o fordismo sem o americanismo. A implementação do americanismo e fordismo nos Estados Unidos representa o sucesso de um projeto hegemônico das classes dominantes para recuperar-se da crise econômica e afastar-se do perigo do avanço comunista em sua sociedade, sem, no entanto recorrer ao fascismo.

“Americanismo e Fordismo" é um importante artigo de referência para esta pesquisa, uma vez que permite o contato privilegiado com os principais conceitos de Gramsci e possibilita verificar a aplicação do consentimento como "motor" do desenvolvimento da sociedade americana daquela época. Esse consentimento, para Gramsci, convive com a coerção na construção e consolidação da hegemonia de uma classe sobre as demais dentro da sociedade; prevalece sobre a coerção na consolidação de um domínio social e, sendo assim, a perspectiva de construção do poder por meio do consentimento é mais efetiva do que somente a utilização da coerção. Partindo desta premissa, a luta pela construção da hegemonia a partir do consentimento pela classe dominada é importante, particularmente quanto à disputa em torno de valores e ideias a respeito de como a sociedade funciona e deve funcionar. A construção do consentimento, ainda que apresente desvantagens devido ao fato de ser uma luta desigual, é fundamental para a classe trabalhadora na disputa dos valores envolvidos na sociedade e no combate ao discurso ideológico da burguesia, que é hegemônico.

A discussão realizada pelo autor nos fornece importantes elementos para o emprego do conceito de consentimento frente às mudanças verificadas atualmente na condição operária. Além disso, o artigo em destaque foi norteador de pesquisas posteriores, tornando-se referência para autores que aplicaram este conceito de modo satisfatório e influenciando de maneira significativa trabalhos de grande envergadura teórica, como o de Burawoy em Manufacturing Consent (1982). 


\subsection{0 consentimento na indústria}

Michael Burawoy analisou a formação do consentimento na indústria. $\mathrm{O}$ autor possui múltiplos estudos sobre as transformações do capitalismo, utilizando o método de estudo de caso ampliado, em que aplica uma ciência sociológica reflexiva à etnografia para analisar diferentes empresas industriais no mundo, privilegiando a perspectiva dos trabalhadores com a intenção de captar o geral a partir do singular, compreendendo o "macro" a partir da análise do "micro". Nesses estudos, Burawoy procura demonstrar que as experiências dos trabalhadores nos seus locais de trabalho refletem, de forma mais geral, a estrutura da sociedade.

Assim como Gramsci, para Burawoy o âmbito da produção contém diversos elementos que auxiliam na construção e perpetuação do consentimento. Ao contrário de algumas tendências que só enxergam no mundo produtivo relações de sujeição e coerção sobre os trabalhadores, o autor compreende que o âmbito da produção possui elementos políticos e ideológicos que são fundamentais para a transformação da força de trabalho em trabalho propriamente dito. Mesmo reconhecendo algumas tendências gerais à degradação do trabalho, Burawoy afirma existir uma tendência de se conservar uma relativa liberdade de escolha fundamental para explicar o porquê de os trabalhadores aumentarem a produtividade em benefício da empresa e aplicarem a dominação capitalista sobre si mesmos ${ }^{20}$. Para ele, as mudanças ocorridas no modelo de organização do trabalho seriam imersas em conflitos de grande amplitude se houvesse apenas a coerção nas relações de produção; existe o aspecto de consentimento nestas relações: as transições pelo "alto" são acompanhadas por algumas demandas vindas dos de "baixo", para diminuir a insegurança.

A ocorrência do consentimento na indústria foi analisada por Burawoy e descrita em seu livro Manufacturing Consent (1982). Sua pesquisa é fundamental para a compreensão da construção do consentimento a partir dos chamados jogos de making out ${ }^{21}$, da formação do mercado de trabalho interno e do Estado interno. Nesse sentido, cabe analisar as contribuições

\footnotetext{
${ }^{20}$ (Ver também para mais detalhes: BRAVERMAN, 1977; CASTRO \& GUIMARÃES, 1991).

${ }^{21}$ De forma resumida: são jogos realizados no chão de fábrica, em que os trabalhadores são envolvidos em uma espécie de disputa com metas relativas a serem alcançadas. Nessa disputa há um comprometimento dos trabalhadores com a empresa e quando são bem sucedidos no jogo, conquistam uma satisfação residual referente às suas funções no chão de fábrica, contribuindo muito para a construção e consolidação do consentimento na indústria.
} 
que o autor apresenta nesse livro e que são essenciais para a definição sobre o consentimento na pesquisa.

No início do seu texto Burawoy afirma que "ao contrário dos que argumentam que a gestão de conflitos entre o trabalhador e a organização no local de trabalho é endêmica ou 'estrutural', vou procurar mostrar como os conflitos e o consentimento são organizados na base da fábrica" (BURAWOY, 1982: 4) ${ }^{22}$. Fica claro que para o autor os conflitos existentes entre os trabalhadores no chão de fábrica devem ser compreendidos dentro da perspectiva política e ideológica envolvida na organização e na produção dos trabalhadores, e não considerando os operários como irracionais nas suas relações com a fábrica, somente. Ele afirma, ainda: “A importância da regulamentação (das relações de trabalho) será fundamental para a minha interpretação da política de chão de fábrica, embora sua incidência seja compreendida em termos de dominação, ao invés de eficiência" (BURAWOY, 1982: 5).

O autor discute o surgimento de uma ampla gama de estudos sobre o trabalho, denominados como Teoria das Organizações. Tais estudos apresentam importante referência em relação à penetração de padrões burocráticos e de relações mercantis em todos os domínios da sociedade, ao mesmo tempo em que falham em não fazer projeções sobre as raízes da sociedade capitalista, acabando por se pautarem em teorias gerais que escondem as características historicamente específicas da produção capitalista. Estas teorias têm como foco a persistência da organização, sua eficiência, a ausência de concorrência, etc., porém essas organizações não persistem: "as teorias da persistência da organização têm concedido as condições de persistência, e ignoram as tendências para a erosão das muitas condições de reprodução de relações" (BURAWOY, 1982: 7).

É necessário haver uma análise mais ampla dos processos envolvendo o chão de fábrica, principalmente quanto à questão da reprodução:

\footnotetext{
"Uma vez que a questão da reprodução é inserida, é preciso ir além da organização e examinar a relação entre as diferentes partes da sociedade que garantem sua reprodução. Mas isso implica, em primeiro lugar, analisar o que produzem as diferentes organizações e, em segundo lugar, reconhecendo que não só produzem coisas úteis ou "serviços", mas que, direta ou indiretamente, elas também produzem lucro. (...) Não só seria ultrapassar a teoria da organização, seria também negar o direito a esta última de existir como uma empresa distinta”. (BURAWOY, 1982: 7).
}

\footnotetext{
${ }^{22}$ Tradução própria do autor da pesquisa.
} 
O processo de trabalho no capitalismo envolve não só a produção de coisas úteis, como descreve a Teoria das Organizações, mas também e essencialmente a produção de lucro. A Teoria da Organização proporciona um paradoxo, pois há duas vertentes que apresentam divergência sobre as relações no chão de fábrica. A primeira vertente parte da premissa que as relações de trabalho estão permeadas de conflito e a partir deste fato é necessário à organização estabelecer medidas de controle social. Tendendo ao máximo à construção de tipologias gerais para explicar os conflitos, esta vertente tem como inspiração a linha teórica de Weber e sua grande falha é não ter a capacidade de explicar sobre o consenso encontrado em diversas organizações. A segunda vertente, por sua vez, entende que as relações de trabalho são marcadas pela harmonia e o consenso, de maneira que o conflito não é natural ou inevitável; se há algum tipo de conflito ele é explicado pela persistência de alguma irracionalidade do trabalhador ou da gestão. Esta vertente tem como inspiração a linha teórica de Durkheim e sua grande falha é não conseguir explicar os conflitos sem recorrer às irracionalidades transitórias, defendendo o capitalismo a partir do postulado de que o conflito não é uma característica essencial do capitalismo. Para Burawoy é preciso inverter a abordagem que está sendo realizada:

"Conflito e consentimento não são condições primordiais, mas os produtos
da organização particular do trabalho. Devemos evitar ficar presos em
diversos debates entre "teoria do consenso" e "teoria do conflito" e mover o
discurso sobre um terreno completamente diferente. Para isso, é preciso
restaurar o contexto histórico para a discussão. Nossa primeira tarefa,
portanto, é compreender a especificidade do processo de trabalho capitalista,
que é distinto do processo de trabalho pré-capitalista e pós-capitalista"
(BURAWOY, 1982: 12).

É necessário entender a particularidade da sociedade capitalista, considerando que ela emergiu historicamente e apresenta características distintas das sociedades pré-capitalistas. O autor realiza uma comparação entre o feudalismo e o capitalismo para evidenciar as diferenças envolvendo esses dois modos de produção. O feudalismo é por ele definido de maneira simples:

"Uma característica definidora das relações feudais de produção é a apropriação do trabalho de mais-valia na forma de aluguel; os servos para se manterem na terra que eles mantinham de acordo com a vontade do mestre ou do senhor eram compelidos a gerar um aluguel em espécie, dinheiro, serviços de trabalho, ou mais comumente numa combinação disso tudo. (...) 
O ciclo de produção na sua forma mais simples é então como se segue: os servos trabalham na propriedade do senhor por tantos dias na semana, e nos dias restantes eles cultivam sua própria terra com o intuito de sobreviver. A primeira é um trabalho fixo e de mais-valia, a última é um trabalho necessário" (BURAWOY, 1982: 21).

A partir desta definição simples, Burawoy destaca cinco aspectos fundamentais do período feudal, os quais cabe ressaltar para uma melhor compreensão do capitalismo. Primeiro, o trabalho necessário e o trabalho de mais-valia são separados tanto no tempo como no lugar; segundo, os servos têm a posse imediata dos produtos necessários para a sua subsistência; terceiro, os servos possuem a capacidade de colocar os instrumentos de produção em movimento independentemente do seu senhor; quarto, as atividades produtivas que constituíam o trabalho de mais-valia eram especificadas e asseguradas através de instituições políticas legais; e, por fim, o direito do senhor de excluir os servos da terra que eles cultivavam para seu próprio uso era protegido pelo aparato regional do Estado, o que acarretava que os servos não conseguissem escapar desse trabalho; ao mesmo tempo, ideologias de troca justa e de proteção militar presentes no sistema de exploração apresentavam-no como natural e inevitável.

A geração de mais-valia nesse modo de produção é transparente, não se produz nem automaticamente nem simultaneamente com aquela de subsistência. Assim, como a produção de mais-valia é separada da produção do trabalho necessário, a apropriação da mais-valia está diretamente relacionada com as esferas política, legal e ideológica. Já no capitalismo, os trabalhadores não podem, por si mesmos, transformar a natureza ou gerar a sua própria subsistência. $\mathrm{O}$ trabalhador tem de vender a sua força de trabalho para o capitalista em troca do salário, que por sua vez é transformado em meios de subsistência.

Burawoy também apresenta o contraste do capitalismo em relação ao feudalismo a partir de cinco aspectos: primeiro, não há separação tanto no tempo como no espaço entre o trabalho necessário e o trabalho de mais-valia, que estão intimamente ligados; segundo, os trabalhadores não podem viver imediatamente do que produzem no seu trabalho. Ao contrário dos servos que podiam viver da terra que cultivavam, os trabalhadores do capitalismo dependem da venda da sua força de trabalho, podendo estabelecer uma troca no mercado para consumir os produtos necessários para a sua subsistência, de modo que "a existência de um mercado é uma característica necessária do capitalismo, sob a qual todos os agentes de produção dependem" (BURAWOY, 1982: 24); terceiro, os trabalhadores não possuem os 
meios de produção e muito menos podem colocá-los em movimento automaticamente, por si próprios, sendo eles controlados em seu processo de produção; quarto, esta direção do processo de trabalho é muito distinta da supervisão e coordenação exercidas pelos capatazes do senhor na produção feudal. No feudalismo as atividades produtivas são definidas nos tribunais do senhor, fora do processo de trabalho, já no capitalismo a administração existe não somente para coordenar, mas também (e o que é fundamental na diferença entre capitalismo e feudalismo) para controlar; e quinto, a interdependência do trabalhador e do capitalista é diferente daquela entre servo e senhor no período feudal:

\begin{abstract}
"O relacionamento entre o senhor feudal e o servo é garantido através do direito do senhor de excluir o servo da terra, um direito definido e protegido em instituições políticas e legais. Enquanto que a relação entre o trabalhador e o capitalista é baseada na sua interdependência econômica. Sob o capitalismo a produção de mercadorias é simultaneamente a produção do trabalhador por um lado, (através do trabalho necessário, o salário equivalente) e do capitalista, por outro lado, (por meio da produção da maisvalia e da sua realização na forma de lucro). Isto é, a produção de mercadorias é simultaneamente a reprodução das relações de produção. Enquanto sob o feudalismo a produção para o senhor está relacionada à produção do servo através de mecanismos políticos - legais" (BURAWOY, 1982: 25).
\end{abstract}

No capitalismo não há o reconhecimento do status produtivo do trabalhador, do capitalista, dos administradores e etc., como existia no feudalismo com a especificação por meio de instituições políticas, legais e ideológicas do status produtivos de alguns agentes que participavam da sociedade feudal. Considerando o capitalismo a partir de uma categoria abstrata de "cidadãos", a relação entre agentes de produção transforma-se em uma relação entre cidadãos.

No período capitalista é perceptível que a produção de mais-valia torna-se um problema em comparação com o período feudal. "Sobre o feudalismo é o trabalho de maisvalia na forma de aluguel que é fixado de antemão, enquanto que no capitalismo é o salário que é pré-determinado" (BURAWOY, 1982: 26). Para Burawoy a mais-valia não está garantida com a compra da força de trabalho, sendo necessário garanti-la por meio de algum mecanismo. Este mecanismo de realização da mais-valia no período em que Marx analisa o processo produtivo é o emprego da coerção por parte dos capitalistas sobre os trabalhadores. Marx não discorre sobre o consentimento na produção justamente porque sua existência era pequena se comparada ao emprego da coerção: 
"Com a passagem do tempo como resultado das lutas das classes trabalhadoras, o salário torna-se cada vez mais independente do gasto individual de esforço, com isso, a coerção deve ser suplementada pela organização do consentimento. (...) o consentimento é expresso através e é o resultado da organização das atividades. Ele deve ser distinguido ou separado da consciência específica ou dos atributos subjetivos do individuo que se engaja nessas atividades. Com o processo de trabalho, a base de consentimento reside na organização das atividades, como se elas apresentassem ao trabalhador escolhas reais, independentemente de quão restritas tais escolhas possam ser. É a participação na escolha que gera o consentimento. Enquanto as aplicações da força forem restritas às transgressões destes limites de escolha (específicos e reconhecidos), ela também pode ser objeto de consentimento. Assegurar o valor da mais-valia, portanto, deve ser entendido como resultado de diferentes combinações de força e consentimento" (BURAWOY, 1982: 27).

Assim, garante-se a mais-valia a partir da combinação de coerção e consentimento no âmbito da produção, o que não garante sua realização em valor real. No feudalismo a maisvalia é fixada, assumindo uma forma divisível e, em geral, diretamente consumida. No capitalismo o trabalho de mais-valia é obscurecido e não pode ser consumido imediatamente. A partir disso, as origens do lucro capitalista são escondidas de várias e diferentes formas. Primeiro, o lucro dos capitalistas parece provir do investimento e introdução de novas técnicas de trabalho, novas máquinas e tecnologias, o que em uma visão mais obscurecida faz parecer aos capitalistas que sua fonte de renda é o capital e não o trabalho; segundo, a maisvalia se realiza na forma de lucro, somente com a venda das mercadorias no mercado. Ao capitalista o lucro não é apenas realizado no mercado; ele parece originar-se de lá, já que o preço de uma mercadoria não é definido pelo capitalista e sim por uma relação determinada pelas forças do mercado quanto à demanda e a oferta. "O obscurecimento do valor de mais valia apresenta-se a si mesmo como um problema de assegurar e realizar o valor de mais valia para o capitalista" (BURAWOY, 1982: 28), ao mesmo tempo em que essa é uma característica necessária do capitalismo para a subordinação dos trabalhadores. Para os trabalhadores, o processo de produção produz coisas de valor de uso, ao invés de produzir valor de troca. "Isso é reforçado pela separação institucional da propriedade e do controle, isto é, pela separação das relações de produção das relações na produção ${ }^{23}$ " (BURAWOY, 1982:

\footnotetext{
${ }^{23}$ As relações de produção são caracterizadas como as relações que são estabelecidas no conjunto da sociedade, entre aqueles que produzem as necessidades da vida e aqueles que vivem a partir dos produtos dos outros, entre aqueles produtores de mais-valia e aqueles que se apropriam dela, entre aqueles explorados e aqueles que exploram, entre o camponês e o senhor, o trabalhador e o capitalista. Já as relações na produção são aquelas nas
} 
28). De forma geral os trabalhadores não atribuem ao seu próprio trabalho a diferença entre o que eles produzem e o que eles recebem. Para Burawoy o essencial no processo capitalista é:

\begin{abstract}
"A essência definidora do processo de trabalho capitalista é simultaneamente o obscurecimento e a segurança do valor de mais-valia. (...) O obscurecimento do valor de mais valia é necessário, mas não condição suficiente para assegurar o valor de mais-valia. Em outras palavras, isso é necessário para explicar não apenas porque os trabalhadores agem de acordo com um conjunto de interesses imputados, mas também porque eles tentam realizar um diferente conjunto de interesses. O processo de trabalho, no entanto, deve ser entendido em termos das combinações especificas de força e consentimento que extraem cooperação na busca do lucro" (BURAWOY, 1982: 30).
\end{abstract}

Neste sentido, torna-se fundamental entender a combinação entre força e consentimento presente na fábrica.

Alguns estudos da Sociologia Industrial buscaram restaurar os momentos subjetivos do trabalhador. Ao mesmo tempo em que queriam enxergar esses momentos como imutáveis, apresentam o trabalho assalariado e a escassez do trabalho industrial como inevitáveis a um regime de escassez. Nesses estudos, os trabalhadores se esforçam para compensar as privações a que estão sujeitos e, para tanto, o trabalho duro que é realizado gera também certa satisfação residual. "As realidades do trabalho, (condições físicas, reprodutividade e rotinas), geram privações, (delibitação, tédio, cansaço), e privações geram satisfações relativas: (hábito, docilidade e contentamento)" (BURAWOY, 1982: 78). No processo de adaptação os operários desenvolvem certa "satisfação residual", em que quanto mais apto ele se sente por realizar o trabalho (ajustar-se de maneira bem sucedida ao ritmo de trabalho), mais satisfeito ele se torna por fazer parte do grupo operário.

Essas satisfações residuais são frequentemente constituídas na forma de jogos, o que reduz a tensão de uma série interminável de movimentos sem sentidos. O jogo supõe regras que são compartilhadas pelos operários, com uma interação de natureza solidária, com certa liberdade e autodeterminação que ainda existe no espaço do trabalho. Há uma idéia de "ajuste" (do ritmo às suas necessidades), de colaboração com uma finalidade: o trabalho. Existe a ideia de "making out", em que o trabalhador supera o cansaço e enfrenta o processo de trabalho com certa margem de manobra. Os sociólogos que descrevem essas relações

quais se produz propriamente o valor de uso das mercadorias, é o espaço da produção no qual se estabelece uma relação direta dos trabalhadores com os objetos de seu trabalho, como é o caso de gerentes e etc.. 
expressam ambivalência quanto à existência desses jogos. Por um lado acreditam que eles têm a função de contribuir para a saúde psicológica e social do trabalhador, por outro, entendem que essas satisfações minam os objetivos da administração.

Os estudos compartilham, ainda, a perspectiva de que existe um código de conduta no trabalho próprio dos trabalhadores, que criam autonomamente os seus próprios sistemas culturais e de produção em oposição à administração. No entanto, tal perspectiva não encontra sentido nas evidências empíricas; nos lugares em que há jogos eles geralmente não são nem independentes, nem estão em oposição à administração.

A partir do estudo de Burawoy a respeito dos jogos, ele afirma que estes não se realizam em oposição à administração, mas contam plenamente com as gerências mais próximas:

\begin{abstract}
"Estabelecer um novo nível para certo trabalho poderia significar rotação de pessoal, já que os trabalhadores tendem a se transferir para trabalhos onde as taxas são atingidas de maneira mais fácil. Como resultado, haveria custos de treinamento, níveis mais baixos de produção, mais desperdício e assim por diante. De maneira alternativa, os operadores se engajariam em preguiça, porque a nova taxa era mesmo impossível, e isso também implicava em níveis mais baixos de produção" (BURAWOY, 1982: 80).
\end{abstract}

Os jogos, então, não são criados autonomamente pelos trabalhadores:

\begin{abstract}
"Ao invés disso, esses jogos emergem historicamente a partir da luta e da barganha, mas eles são jogados dentro dos limites definidos pelo salário mínimo e pelas margens de lucro aceitáveis. A administração pelo menos nos níveis mais baixos, participa ativamente não apenas na organização do jogo, mas no cumprimento das suas leis. O estimulo para engajar-se em tais jogos de trabalho vem tanto da coerção inevitável de vir para trabalho, quanto da subordinação aos ditames do processo de trabalho, uma vez que você esta lá. E também do surgimento das necessidades radicais e de uma nova visão de trabalho ou de um código não lógico. Entra-se no jogo pelas suas satisfações residuais, ou o que Herbert Marcuse chama de satisfações repressivas. Jogo representa uma necessidade que é estritamente o produto de uma sociedade cujos interesses dominantes exigem repressão. A satisfação dessa necessidade reproduz não apenas a servidão voluntária, ou consentimento, mas também maior riqueza material" (BURAWOY, 1982: $80)$.
\end{abstract}

O Jogo insere o trabalhador como um indivíduo nas relações na produção ao invés de membro de uma classe. Os trabalhadores controlam as máquinas que utilizam no processo produtivo, o que reforça a ideia de que eles são responsáveis enquanto indivíduos por 
controlar o processo produtivo. O sistema de recompensa é baseado no esforço individual e não coletivo. Com isso tem-se "a consequência de redistribuir o conflito de uma direção hierárquica numa direção horizontal, no qual os trabalhadores individuais encaram um ao outro em conflito ou competição" (BURAWOY, 1982: 81). A participação dos trabalhadores no jogo cria o consentimento:

“A própria atividade de jogar um jogo gera consentimento com relação às
suas regras. O ponto é mais importante é de que não se pode jogar um jogo e
ao mesmo tempo questionar as regras. A indagação que se apresenta
logicamente e empiricamente: jogar o jogo ou a legitimidade das regras?
Aqui eu não estou argumentando que jogar o jogo esta baseado no consenso
amplo, pelo contrário, o consentimento ou o consenso repousa ou está
construído através de se jogar o jogo. O jogo não reflete uma harmonia
subjacente de interesses, pelo contrario, ele é responsável por e gera aquela
harmonia. A fonte do jogo em si mesma reside não no consenso pré-
ordenado de valores, mas em lutas historicamente específicas para adaptar a
escassez inerente no trabalho e nas lutas com a administração para definir as
regras". (BURAWOY, 1982: 81).

Nesse sentido, é o jogo que pode estabelecer um consentimento e não o contrário. As regras são avaliadas em termos dos resultados definidos do jogo, progredir ou não progredir. Os resultados vão além do lucro, o jogo também tem como consequência a reprodução das relações capitalistas de produção:

"Portanto, na medida em que é institucionalizado, assim como é a
progressão, o jogo torna-se um fim em si mesmo, mascarando, ofuscando e
até invertendo as condições a partir das quais ele emerge. Enquanto os
jogadores estiverem engajados num jogo em que envolve as suas relações
com uma máquina, a sua subordinação num processo de produção torna-se
um objeto de consentimento, de igual modo à incorporação num jogo
envolve outros agentes de produção: trabalhadores, chefes de seção"
(BURAWOY, 1982: 82).

A partir disso é possível verificar duas consequências em se participar do jogo: primeiro, jogar o jogo obscurece as relações de produção em resposta as quais o jogo é originalmente construído; segundo, o jogo gera o consentimento nas relações sociais na produção, que definem as regras sociais do jogo. "A violação individual em oposição à coletiva das regras leva a uma punição ritual que tem o efeito de reforçar essas consequências obscuras e que produzem consentimento" (BURAWOY, 1982: 82). 
Burawoy relata ainda em seus estudos que as insatisfações dos trabalhadores com a empresa, que ele imaginou pudessem ser em razão de uma noção vaga de exploração, eram na realidade uma insatisfação com as decisões impostas pela mesma para a realização do jogo. A administração estava sendo acusada de enganar os trabalhadores, sabotando as máquinas ou dificultando todo o processo de metas envolvidas no trabalho, de não estar jogando com as regras do jogo. "E essas acusações serviam para reforçar a legitimidade das regras e dos valores do jogo. Desta forma, o aparato consensual estava continuamente sendo restabelecido e reforçado" (BURAWOY, 1982: 83).

A realização do jogo não está ligada somente aos ganhos financeiros da progressão do trabalhador ou aos possíveis ganhos externos possibilitados pelo sucesso no jogo:

\footnotetext{
“As recompensas da progressão (Making out) são definidas em termos de fatores diretamente relacionados ao processo de trabalho: redução do cansaço, passar um tempo, aliviar tédio e assim por diante. E fatores que emergem e que surgem a partir do processo de trabalho, como as recompensas sociais e psicológicas da progressão num trabalho difícil, assim como o estigma social e as frustrações psicológicas ligadas a falhar num trabalho de ganho fácil" (BURAWOY, 1982: 85).
}

A realização do jogo, o "jogar” o jogo em si, é que gera um interesse comum no resultado e na continuidade do jogo. As atividades realizadas no chão de fábrica são avaliadas e os interesses estabelecidos a partir da consequência do jogo, isto é, os interesses não são dados e nem trazidos de fora do ambiente da fábrica. Ao contrário, eles são organizados pela forma específica de relações na produção. Esses jogos surgem de fato da iniciativa dos trabalhadores para suportar a subordinação no processo de trabalho, porém quando necessário eles são regulados coercivamente pela administração e contam com a participação ativa dos administradores. A partir do momento em que o jogo é estabelecido ele pode assumir uma dinâmica por si mesmo.

Há um dilema presente na realização do jogo, aquele entre o trabalhador individual e o trabalhador coletivo, no qual a realização da progressão no jogo pelos trabalhadores individuais ao mesmo tempo em que possibilita uma remuneração superior a estes, acaba minando o interesse coletivo, pois aumenta a progressão a ser atingida pelo trabalhador, aumentando a produção individual às custas da eficiência coletiva e gerando grandes danos pelo aumento da concorrência entre os trabalhadores. Deste modo, o jogo em si produz condições que o fazem mais difícil de ser jogado. 
Um jogo pode perder seu interesse a partir de três condições: primeira, quando a incerteza é grande demais e o resultado está totalmente além do controle dos jogadores; segunda, quando a incerteza é muito pequena e o resultado pode ser controlado pelos jogadores; e terceira, quando os jogadores estão indiferentes a qualquer um dos resultados possíveis. Burawoy relata que ele próprio descartava o jogo e com o tempo passou a ser atraído pelo mesmo, tornando-se um jogador ávido. Até se tornar um "jogador”, o autor era objeto de desprezo e desdém, condenado ao ostracismo.

"Além disso, jogando o jogo trouxe outras recompensas sociais - nomeadas, fisiológicas. Quando um está tentando tornar-se (atingir os objetivos do jogo), o tempo passa mais rápido - de fato, muito rápido - e menos consciente estando cansado. A diferença entre tornar-se e não tornar-se não era tão mensurada em alguns centavos de bônus que nós ganhávamos em prestígio, senso de realização, e orgulho. Jogando o jogo eliminou muito do trabalho penoso e do tédio associado ao trabalho industrial" (BURAWOY, 1982: 89).

A participação no jogo está condicionada em dois limites de incerteza nos resultado:

\begin{abstract}
"De um lado, os trabalhadores tem de ter garantido um salário mínimo aceitável, de outro lado, os gerentes tem que ter assegurado um nível mínimo de lucro. Enquanto o jogo nunca ameaçar o salário mínimo diretamente, isto pode em determinadas circunstâncias por em perigo o lucro. Eu teorizo esse primeiro tipo de crise como uma 'crise do sistema'. Uma crise de um segundo tipo brota da retirada dos trabalhadores do jogo, tanto por causa de muita ou pouca incerteza na realização de 'tornar-se' (crise da legitimação) ou porque jogar já não tem qualquer valor para os jogadores (crise motivacional)" (BURAWOY, 1982: 89).
\end{abstract}

Nesse contexto, é necessário estabelecer a relação que há entre as crises do sistema e as crises de legitimação ou motivacional. Com certeza uma crise de legitimação ou motivacional vai provocar uma crise do sistema. Mas uma crise do sistema pode resultar de outros fatores além do colapso e da demissão, como, por exemplo, os custos de treinamento muito elevados ou de horas-extras excessivas.

O conceito de jogo para Burawoy é mais do que uma ferramenta analítica, é também uma ferramenta de crítica:

"Primeiro, ele representa o elo entre a racionalidade individual e a racionalidade do sistema capitalista. Assim como jogadores em um jogo, que adotam estratégias que afetam os resultados, mas nem sempre da forma 
pretendida, em nosso cotidiano fazemos escolhas, a fim de influenciar os resultados. A variação dos resultados possíveis é limitada, mas não é inteiramente fora de nosso controle. (...) A metáfora do jogo sugere uma 'história' com 'leis' próprias, além do nosso controle e, ainda assim o produto de nossas ações". (BURAWOY, 1982: 92).

Assim como um jogo gera a concordância com suas regras, o modo como o trabalhador participa do capitalismo também o obriga a escolhas que concordem com suas regras, suas normas. É por sua vida realizar-se como uma série de jogos, um conjunto limitado de escolhas, que as relações capitalistas não só se tornam objeto de consentimento, como são consideradas dadas e imutáveis. Não se decide coletivamente sobre o que é estabelecido, ao contrário, obriga-se o trabalhador a jogar o jogo, e então procede-se em defesa das regras. Do mesmo modo que o jogo define um conjunto de objetivos, o capitalismo gera um conjunto de interesses. Os interesses são tomados como dados, e como as regras, eles não são formados através do consenso democrático. A possibilidade de ganhar ou de maximizar o ganho faz um jogo sedutor. Portanto, a possibilidade de realização dos seus interesses, das necessidades de satisfação definidas pelo capitalismo em geral ou por fazer, em particular, é o próprio meio para a geração de consentimento para as regras e relações, apresentando-as como naturais, imutáveis e inevitáveis; as alternativas são eliminadas ou afirmadas como utópicas. "Em suma, a insatisfação, que é grande, não é dirigida contra o capitalismo, mas para sua reprodução" (BURAWOY, 1982: 93).

Analisando o jogo, Burawoy analisa a relação entre o mercado interno de trabalho e as atitudes dos trabalhadores no chão de fábrica. O tipo puro do mercado interno de trabalho se assemelha muito às grandes empresas japonesas atualmente. Há populações relevantes de indivíduos e lugares, que são os empregados e ocupações em uma determinada empresa, e existe um sistema de intercâmbio dentro da mesma, que regulamenta a promoção, oferta de emprego, a fixação de salários, geralmente baseados em uma combinação de antiguidade e habilidade.

"O conceito de mercado interno de trabalho é importante à sensibilização para uma ligação entre mudanças internas e externas no surgimento da empresa moderna. Mais especificamente, as funções até então realizadas pelo mercado de trabalho externo têm sido progressivamente absorvidas pela empresa - uma internalização bastante literal. Mas o que é de importância, aqui não é o contraste entre os mercados de trabalho internos e externos, mas a sua semelhança" (BURAWOY, 1982: 96). 
A partir desta definição o autor analisará mais precisamente as mudanças que sofreu o mercado interno de trabalho, principalmente a partir das mudanças que a empresa em que realizou sua pesquisa sofreu nos últimos trinta anos. Lá, há uma mobilidade cada vez mais reduzida de indivíduos de fora e uma maior mobilidade dentro da empresa, com o recrutamento reduzido de trabalhadores externos, cuja entrada se dá somente nos níveis mais baixos.

"O surgimento de um mercado de trabalho interno requer, por um lado, que trabalhadores uma vez recrutados de modo geral escolham permanecer com a empresa ao invés de procurar emprego num outro lugar. Por outro lado, requer que a empresa tente preencher vagas de trabalho, selecionando dentre seus próprios trabalhadores antes que recrute os trabalhadores do mercado de trabalho externo. Em outras palavras, os incentivos devem ser fornecidos para os trabalhadores permanecerem com a empresa e para a empresa recrutar trabalhadores de sua força de trabalho própria. Com estes pontos em mente, discutirei seis condições ou aspectos do mercado de trabalho interno, ou seja, uma estrutura de trabalho diferenciada, um meio institucionalizado de disseminar informações e apresentar os pedidos de vagas, os critérios não-arbitrários para a seleção de funcionários para as vagas, um sistema de treinamento no trabalho, formas de gerar um compromisso com a empresa que faz o trabalho em outras empresas sem atrativos, e, finalmente, manter a lealdade dos funcionários depois que eles foram demitidos." (BURAWOY, 1982: 97).

Nesse sentido, Burawoy começa realizando uma comparação entre os períodos de 1945 e 1975, em que realizou sua pesquisa. Em 1945, a transferência de trabalhadores não era bem vista pelos mesmos e era frequentemente utilizada como medida disciplinar. Só havia três graus diferenciados no acordo do contrato de trabalho, com pouca vantagem em mudar de posição dentro da fábrica, sendo melhor ganhar mais experiência numa máquina visando melhorar a sua chance de progredir. Já em 1975 havia doze graus com diferentes bases de ganhos e maiores alternativas em relação à transferência de trabalhadores. Além da estrutura de emprego possuir algumas vantagens para que o trabalhador da empresa deseje permanecer e obter sucesso dentro dela, um mercado interno de trabalho requer um sistema por meio do qual os trabalhadores podem escolher e concorrer por aberturas e ofertas de vagas. Em 1945 os operários podiam recorrer às transferências simplesmente abordando o superintendente, "não havia um sistema para informar aos empregados quando as aberturas de vagas aconteciam, para se inscrever para tais aberturas ou para se assegurar que os empregados estavam tendo a preferência, comparando-se com os inscritos de fora." (BURAWOY, 1982: 
100). Dava-se, ainda, ênfase ao sistema de veteranos, que tendia a prender o empregado dentro de um único departamento. Já em 1975, existia um leilão completo que envolvia a abertura de vagas, um sistema para se inscrever nos empregos e um sistema de seleção entre os concorrentes.

Em relação aos treinamentos, em 1945 não havia nenhuma referência à responsabilidade da administração nos mesmos, já em 1975 o contrato estimulava que houvesse treinamento, sendo muito frequente os operários mais antigos treinarem os mais novos, recebendo a mais por isso, embora o treinamento não fosse bem realizado em muitos casos: "A hostilidade entre o aprendiz e o treinador pode ser especialmente severa ou intensa quando o novato apresenta algum tipo de ameaça ao treinador" (BURAWOY, 1982: 102). O aprendiz pode, em alguns casos, representar um oponente a ser destruído quando ameaça o treinador na realização das suas horas-extras, uma vez que este aprendiz entraria no chão de fábrica e o treinador não poderia cumprir as horas-extras que costumava realizar.

Em termos de atratividade para os seus funcionários, a empresa oferece vantagens aos trabalhadores que permaneçam mais tempo em seus quadros e em troca recebe um maior compromisso do trabalhador com a empresa. Deste modo, as recompensas pelo tempo de serviço desestimulam o empregado a procurar outras empresas para trabalhar. Em relação às demissões, o quadro não mudou significativamente; com os desenvolvimentos recentes no mercado interno de trabalho, organizou-se a disponibilidade continuada das pessoas envolvidas no trabalho, mesmo durante os períodos de depressão, permitindo que as demissões acontecessem baseadas no esquema de tempo de serviço, levando-se em conta toda a fábrica ao invés de apenas um departamento.

"O mercado de trabalho interno promove mobilidade dentro da firma e reduz a mobilidade entre firmas. A escolha aberta aos funcionários dentro da firma, embora seja uma escolha dentro de limitações, promove o mesmo individualismo competitivo que tem sido normalmente associado ao mercado de trabalho externo. Também produz um impacto significativo nos padrões de conflito dentro do chão da fábrica. A oportunidade de mobilidade entre empregos tem o efeito de diminuir o conflito entre trabalhadores e níveis mais baixos de administração, o capataz ou responsável pela seção e o engenheiro industrial. Enquanto os operadores estiverem presos dentro de um único trabalho eles têm que lutar com a pessoa responsável pela determinação e distribuição do tempo, por melhores taxas pagas pela hora. Essa é uma razão pela qual essa pessoa responsável pela distribuição do tempo tinha uma influência tão grande sobre a vida no chão da fábrica em 1945. Quando os funcionários podem ser transferidos com relativa facilidade e à vontade para outros trabalhos com taxas ou com preços mais fáceis, eles 
não têm mais aquele interesse em lutar ou brigar com os métodos do departamento sobre qualquer operação especifica; além disso, eles têm também um interesse diminuído ou menor em proteger as taxas já existentes" (BURAWOY, 1982: 104).

A mobilidade diminui o conflito em uma direção hierárquica e tende a gerar conflitos em uma direção horizontal. A rivalidade por melhores salários leva à competição entre os trabalhadores, que em alguns casos se utilizam de táticas de obstrução ao outro. Partindo-se disto, pode-se dizer que quanto maior a mobilidade entre os empregos, menor a oportunidade de se desenvolver um relacionamento necessário de confiança, em detrimento das relações de tensão e competição entre os trabalhadores.

O treinamento realizado no trabalho também é outro fator de individualização das relações trabalhistas, já que o relacionamento dos trabalhadores é baseado em barganha e autonomia individual.

"O mercado de trabalho interno não apenas redistribui o conflito numa direção horizontal e promove a autonomia através de uma mobilidade limitada. Ele também fornece base material para apresentação dos interesses da empresa, como interesses de todo mundo. As recompensas por tempo de trabalho, ou seja, melhores trabalhos, benefícios marginais, segurança no trabalho, status social e assim por diante, geram um compromisso com o empreendimento e a sua sobrevivência" (BURAWOY, 1982: 106).

Outro fator fundamental é a contribuição do mercado de trabalho interno tanto para o obscurecimento quanto para a segurança do valor de mais-valia, de diversas maneiras:

\begin{abstract}
"Primeiro, ele internaliza os aspectos mais característicos do mercado de trabalho externo, notadamente o individualismo competitivo de trabalhadores livre e iguais. Segundo, a mobilidade que ele gera no ponto de produção, dissolve algumas das tensões entre trabalhadores e gerentes e gera novas tensões entre os trabalhadores. Em ambas destas maneiras, os interesses do trabalhador são constituídos, ou são formados como aqueles de um agente individual contra outros indivíduos, ao invés de entre aqueles de uma classe oposta à outra classe. Por outro lado, ao promover um compromisso com o empreendimento através da recompensa ao maior tempo de trabalho, o mercado de trabalho interno, concretamente coordena os interesses do capitalista e do trabalhador na geração do valor de mais valia" (BURAWOY, 1982: 107).
\end{abstract}

As regras existentes no mercado de trabalho interno restringem a incerteza crescente dentro de limites mais estreitos e, nesse sentido, o mercado de trabalho interno baseia-se num 
complexo de regras por um lado, enquanto expande o número de escolhas por outro. A escolha ganha seus significados ou sua importância a partir do poder material que ela fornece aos trabalhadores, nas tentativas de resistirem ou protegerem a si mesmos da dominação da administração. Os trabalhadores querem a preservação e expansão do mercado de trabalho interno, e isso gera e consolida um consentimento em torno das suas regras e das condições que ele representa, notadamente em um processo de trabalho que tem sido esvaziado de habilidade.

Outro processo importante para a formação do consentimento na indústria analisado por Burawoy é a existência e a consolidação de um Estado Interno. "O termo Estado Interno, refere-se ao conjunto de instituições que organiza, transforma e reprime lutas a respeito das relações na produção e relações da produção no nível de empreendimento" (BURAWOY, 1982: 110). Trata-se de uma re-politização das relações na produção com o surgimento de um governo privado dentro da indústria, mas não de um fato novo:

\begin{abstract}
"Com o surgimento da grande corporação e do sindicalismo, as instituições do estado interno tornaram-se mais desembaraçadas da direção administrativa do processo de trabalho e incorporadas nos procedimento de reclamação e barganhas coletivas. $\mathrm{O}$ surgimento do estado interno protege a prerrogativa administrativa de moldar e dirigir o processo de trabalho através da imposição de restrições ao critério da administração e também por favorecer os trabalhadores com direitos, assim como, com obrigações". (BURAWOY, 1982: 110).
\end{abstract}

Nesse processo, o sindicato tem de ser forte e apresentar respostas aos trabalhadores para que possa ganhar a lealdade dos seus membros, comandá-los e ainda parecer forte o suficiente para fornecer um desafio aos desmandos da administração na organização e no controle do processo de trabalho. O estudo sugere que o apoio do trabalhador ao sindicato é forte enquanto o desafio do sindicato à administração é mais fraco.

A presença do sindicato age como um inibidor da violação do contrato pela administração. Assim, na medida em que a administração age de maneira justa, conforme o contrato, o sindicato parece aos trabalhadores como não fazendo nada. As queixas ao sindicato colhidas pelo autor em sua pesquisa demonstravam que elas estavam dirigidas aos indivíduos que exerciam alguma função no sindicato, ao invés de uma queixa ao sindicato enquanto instituição, que geralmente defende os trabalhadores contra as violações exercidas pela administração, independentemente de quem ocupa a gestão em exercício do sindicato. 
O Estado Interno insere o trabalhador como uma espécie de "cidadão industrial", com direitos e deveres definidos contratualmente: "o sindicato age como um árbitro tanto protegendo os direitos dos cidadãos industriais, quanto supervisionando a punição dos transgressores das obrigações contratuais" (BURAWOY, 1982: 113). Cada caso é considerado de forma individual e os méritos são julgados a partir das regras do "governo industrial", que estão especificadas no contrato.

Os sindicatos arbitram e reforçam as regras inscritas no contrato. Como o jogo de making out, a firmeza na proteção das regras do contrato deriva em parte do seu poder em barganhar, em entrar em um acordo, em mudar as regras a cada nova sucessão de gestão do sindicato, que no caso da fábrica pesquisada por Burawoy, representava um período de três anos a cada nova eleição sindical. As barganhas coletivas deslocam os conflitos entre os diferentes agentes no chão de fábrica que podem levar as interrupções no trabalho a negociações mais estruturadas. Com essa mudança, a barganha coletiva gera um interesse comum entre a empresa e o sindicato na sobrevivência e crescimento dessa empresa. A barganha coletiva é uma forma de luta de classes. Nela, os trabalhadores são representados como uma classe em oposição ao capital, embora as lutas girem em torno de mudanças pequenas ou marginais, que não têm nenhum efeito na relação entre capital e trabalho. Ao contrário, os resultados dessas negociações tornam-se objetos de consentimento.

\footnotetext{
"Em outras palavras, barganha coletiva pode ser vista como um outro jogo. Dessa vez um jogo a respeito de regras e resultados de outros jogos, como, por exemplo, o jogo de making out. Como antes o contexto que define as regras da barganha coletiva é como resultado de se jogar o jogo, tido como dado. As violações das regras estabelecidas de barganha coletiva, ou a falha de se chegar a um acordo mútuo, podem levar à greves ou arbitrações compulsórias num nível um pouco mais alto. Numa indústria especifica, onde a barganha coletiva não acontece, ou ela falha, as relações capitalistas podem ser questionadas, mas fora a indústria afetada, as consequências dessa ruptura, muito provavelmente reforçam o compromisso com a barganha coletiva e com um interesse comum com a sobrevivência e crescimento da empresa" (BURAWOY, 1982: 115).
}

A partir disso a barganha coletiva representa um interesse comum entre o sindicato e a empresa, mas esse interesse comum se baseia numa pré-condição material que é o crescimento dos lucros. O Estado Interno é caracterizado pela subordinação dos trabalhadores e da administração à uma lei impessoal. Tal lei assume uma autonomia em si mesma, no sentido de que só pode ser mudada de maneira consensual e não arbitrária, frequentemente 
por meio de barganhas coletivas e de regulações conjuntas. Na fábrica analisada pelo autor a gestão interna é raramente ameaçada pela intervenção de fora; a gestão interna tem sido a portadora de uma privatização da política pública. As agências públicas não intervêm ou ditam à fábrica analisada como ela deve proceder em várias situações, apenas preenchem uma função mais passiva de ratificação e restrição.

O Estado Interno também é autônomo em três sentidos relacionados: primeiro, sujeita os trabalhadores e a administração às regras e regulações do contrato da mesma forma. Essa autonomia é relativa, pois assegura a reprodução das relações na produção e com isso assevera e obscurece o valor de mais-valia; segundo, essa autonomia só é preservada na medida em que o valor de mais-valia é obscurecido e assegurado, já que com uma crise as regras podem ser mais arbitrárias; e terceiro, essa autonomia expressa o poder institucionalizado da empresa e de uma classe trabalhadora organizada a partir do sindicato. "É do interesse da empresa manter a autonomia relativa da liderança sindical, nem que seja para legitimar o sindicato como instrumento de barganha" (BURAWOY, 1982: 117). Assim, é preservada uma autonomia relativa do Estado Interno se forem preservados os acordos entre o sindicato e a empresa e enquanto não houver uma grande colisão visível.

Outro fator fundamental é que haja um mecanismo eleitoral eficiente na política sindical, que possibilite a impressão aos trabalhadores de que eles podem modificar uma determinada situação e conseguirem maiores benefícios para a sua categoria retirando ou modificando quem domina o sindicato. Desta maneira, esse mecanismo eleitoral mascara e legitima o contexto estrutural entre as relações do sindicato e a administração. A relativa autonomia do governo industrial com relação aos aparatos estatais de fora acaba por disfarçar ou mascarar as relações de propriedade, em que as barganhas coletivas desempenham esse papel fundamental.

O Estado Interno e o mercado de trabalho interno desempenham funções semelhantes:

"O estado interno, na sua forma relativamente autônoma, coordena concretamente os interesses do sindicato com os da administração através do uso conjunto do maquinário das reclamações e da barganha coletiva. Ele concretamente coordena os interesses do trabalhador e da corporação na expansão do lucro, que gera concessões materiais na forma de benefícios para o empregado e aumento de salário. Ele obscurece as relações capitalistas de produção no processo de trabalho ao constituir trabalhadores como indivíduos, cidadãos individuais com direitos e obrigações ao invés de 
membros de uma classe e, finalmente, as lutas com relação às relações na produção são reguladas pelo procedimento de reclamação e deslocadas numa barganha coletiva" (BURAWOY, 1982: 119).

Com o surgimento do mercado interno de trabalho as escolhas dos trabalhadores se expandem e, portanto, constituem a base para a construção do consentimento. Porém, esse consentimento surge somente se a administração não define de maneira arbitrária escolhas para os trabalhadores, necessitando das barganhas coletivas. "Além disso, quando confinadas às violações das regras que definem os limites da escolha, a aplicação da força torna-se um objeto de consenso" (BURAWOY, 1982: 120).

Há uma ambiguidade no Estado Interno porque ao mesmo tempo em que ele coordena os interesses dos trabalhadores e da administração, acaba por reconhecer que esses mesmos interesses são antagônicos. De modo diferente do Estado de Direito, que não reconhece a existência de classes na sua estrutura, o Estado Interno explicitamente reconhece as classes e com isso torna-se mais potencialmente vulnerável à luta de classes.

Portanto, o autor, por meio de sua análise do jogo de "making out", do mercado interno de trabalho e do Estado Interno, procurou demonstrar que a aplicação da força foi cada vez mais limitada à violação das regras que definiam uma arena de consentimento que se expandia. Nas palavras de Burawoy:

\footnotetext{
"Ao fazê-lo eu considerei o empreendimento como obscurecendo e assegurando o valor de mais-valia através da organização, da deslocação e da repressão das lutas, pela constituição e apresentação dos interesses da corporação como um interesse de todos e pela promoção do individualismo. Eu também deduzi que o obscurecimento e a consolidação do valor de maisvalia pode ser examinado de maneira independente de tais fatores externos, como o estado global, os mercados e a reprodução da força de trabalho" (BURAWOY, 1982: 120).
}

Para o autor, os instrumentos de consentimento agiriam no dia-a-dia da fábrica, na reprodução das relações de produção, na dimensão subjetiva do trabalhador, transferindo, desse modo, os conflitos antagônicos entre Trabalho e Capital para a arena da definição das regras sobre um conjunto de "maneiras de fazer" do trabalho fabril. Essa transferência pode contribuir para a adesão dos trabalhadores ao interesse do Capital.

A apresentação das relações na produção como permeada de jogos, no qual o trabalhador busca uma satisfação para suportar suas condições de trabalho é uma inovação em relação às explicações que enfatizam o trabalhador como um objeto de manipulação, sem uma 
subjetividade própria capaz de resistência. A inovação teórica de Burawoy permite realizar uma análise mais ampla dos processos ocorridos nas relações na produção, assim como, das particularidades que envolvem a nova classe operária e sua nova condição. 


\section{Capítulo II - As transformações no mundo do trabalho e o Sindicato dos Metalúrgicos de São José dos Campos e Região}

\subsection{A reestruturação produtiva e crise do sindicalismo no Brasil}

A década de 1970 representou grandes transformações econômicas e políticas para os países capitalistas avançados, que levariam a modificações significativas no mundo do trabalho $^{24}$. Na esfera macroeconômica, as contas externas da maioria dos países foram crescentemente desequilibradas devido ao súbito aumento geral dos preços do petróleo pela Organização dos Países Exportadores de Petróleo (OPEP), em 1973 e em 1979. Também fundamental para este desequilíbrio foram as sucessivas valorizações e desvalorizações do dólar, praticamente impostas pelos Estados Unidos, em 1978 e em 1985. Tiveram início, então, as primeiras grandes variações nas taxas de câmbio das economias nacionais, acentuando a internacionalização e o já alto volume de investimentos em capitais financeiros, que, através da tecnologia microeletrônica aplicada à informação, passaram a especular sobre essas flutuações cambiais.

Essa instabilidade macroeconômica ocasionou grande cautela nos investimentos produtivos industriais (que vinham perdendo força nos países capitalistas avançados por causa do crescimento das atividades nos setores de serviços, como finanças, comércio, entretenimento, saúde e etc.). O deslocamento do consumo para esse novo setor e sua consequente concorrência, aliado ao baixo crescimento da indústria nos últimos anos, levou a uma mudança de estratégia de uma padronização em larga escala para a crescente agregação tecnológica, maior qualidade e personalização dos produtos.

Para que esses objetivos fossem alcançados e os defensores do capitalismo afastassem as dificuldades que poderiam colocar em questão a ordem vigente, foram necessários quatro requisitos: primeiro, alta flexibilidade da produção, ou capacidade de produzir diferentes modelos de produtos em um curto espaço de tempo, permanecendo ou não em uma produção em larga escala; segundo, aumento na qualidade dos produtos, o que inclusive reduziria custos de produção, já que haveria um volume menor de retrabalho; terceiro, preços finais mais baixos, o que derivaria não só da redução do retrabalho e da

\footnotetext{
${ }^{24}$ (Ver para mais detalhes: OLIVEIRA \& RIZEK, 2007; ANTUNES, 1999; OLIVEIRA, 1994; MELLO E SILVA, 2007a; LESSA, 2002).
} 
flexibilidade produtiva, mas também da manutenção de uma "fábrica mínima", produzindo sempre com baixa capacidade ociosa, tanto em termos de equipamentos, quanto de estoques e de efetivos de trabalhadores; e por fim, entrega rápida e precisa, com os pedidos sendo entregues no momento exato estipulado pelo cliente, em sua quantidade exata e com um controle de qualidade que lhe garantisse pronta utilização na maioria dos casos. (PINTO, 2010).

Essas mudanças colocaram uma série de questionamentos no modelo de organização do trabalho taylorista/fordista. A produção em série e em larga escala, baseada em unidades produtivas verticalizadas e concentradoras de grande mão de obra especializada, em sua maioria semiqualificadas, tornou-se um obstáculo para o crescimento. Com isso, houve um interesse maior por experiências alternativas na organização do trabalho e na produção industrial, que antes permaneciam restritas a locais específicos.

Dentre os modelos alternativos que obtiveram mais sucesso em sua implementação está o modelo designado como toyotismo, concebido pelo engenheiro industrial Taiichi Ohno na empresa japonesa Toyota Motor Company, desde os anos de 1950. Esse modelo de organização do trabalho colocou-se como um significativo concorrente ao modelo taylorista/fordista, principalmente pela sua adequação ao contexto de instabilidade e de baixo crescimento a partir da década de 1970, e pelas mudanças dos princípios de organização do trabalho que o mesmo defendia ${ }^{25}$. O toyotismo é um dos principais símbolos da reestruturação produtiva que diversas empresas adotaram em suas fábricas, portanto, faz-se necessário uma análise mais detalhada dos seus princípios e postulados para a compreensão do processo de reestruturação produtiva.

O modelo toyotista surgiu no Japão no período posterior à Segunda Guerra Mundial, em que havia um crescimento econômico lento, com um mercado consumidor interno com pequena expansão da demanda, condições estas diferenciadas do surgimento do taylorismo/fordismo, que foi germinado em uma economia em crescimento, contando com um mercado consumidor em expansão, tanto interna quanto externamente. Deste modo, era necessário um aumento simultâneo da produtividade e da capacidade de se produzir quantidades pequenas de diversos modelos de produtos.

\footnotetext{
${ }^{25}$ (Ver para mais detalhes: HIRATA, 1993; WOOD, 1991; GOUNET, 1999; CASTRO, 1995; PINTO, 2003; GORENDER, 1997; CASTRO, 1993).
} 
A Toyota aplicou a partir de 1947 um processo denominado "autonomação", um neologismo oriundo da junção das palavras "autonomia" e "automação", processo no qual é acoplado às máquinas um mecanismo de parada automática em caso de se detectarem quaisquer defeitos no transcorrer da fabricação de um objeto, possibilitando às máquinas funcionarem autonomamente (independentes do controle humano direto) e sem a consequência de uma fabricação de peças com defeitos. Isso permitiu que um único operário fosse capaz de conduzir várias máquinas dentro do processo produtivo, desvinculando-se da relação um trabalhador por máquina típica do período taylorista/fordista. (CORIAT, 1994).

No final da década de 1940 e começo da década de 1950, a Toyota passava por graves dificuldades financeiras e teve que reduzir o seu quadro de funcionários com demissões. Logo após esse período houve a Guerra da Coreia (1950-1953), em que foram realizadas encomendas em massa pelos estadunidenses de pequenas séries de diferentes produtos, com a ameaça de multas pesadas caso não se cumprissem os prazos fixados para as entregas. Isto fez com que a empresa tivesse que aumentar enormemente sua capacidade produtiva, sem a contratação de novos funcionários. A partir do êxito da aplicação do controle de somente um homem para várias máquinas, o engenheiro industrial Ohno perseguiu o objetivo de agregar ao mesmo posto de trabalho máquinas de diferentes funcionalidades, o que possibilitava concentrar em um mesmo local distintas funções de trabalho, o que era impensável no período do taylorismo/fordismo que separava as unidades produtivas em diferentes departamentos.

Com o sucesso com que se aglutinavam grupos de diferentes atividades em um mesmo local, os postos de trabalho foram sendo reduzidos e adquiriu-se o aspecto de "multifuncionalidade", que exigia dos trabalhadores a realização de várias tarefas em diferentes máquinas, dentro da mesma jornada de trabalho. Com a fusão de várias atividades e funções em um mesmo funcionário, os trabalhadores foram denominados como "polivalentes" ou "multifuncionais". O trabalhador polivalente tinha a possibilidade de realizar diferentes habilidades no processo produtivo, quebrando a lógica existente no modelo de organização do trabalho taylorista/fordista, em que havia uma divisão clara entre tarefas de execução e tarefas de concepção, resultando em uma participação mais autônoma dos trabalhadores na produção.

A principal ideia da Toyota era permitir que os trabalhadores adquirissem o conhecimento, executassem suas tarefas e passassem a se responsabilizar pelas várias fases do processo produtivo global, o que lhes permitiria desenvolver múltiplas capacidades, que no 
final seriam reaproveitadas no cotidiano de suas atividades, com aumento da produtividade. $\mathrm{O}$ processo de aplicação desses novos procedimentos internos à fábrica exigiu uma série de sacrifícios dos trabalhadores e sua adaptação foi muito dolorosa para os funcionários, No entanto, não havia naquela situação histórica grandes alternativas aos trabalhadores; havia a necessidade de aceitar as adaptações ou perder o emprego. Nesta nova organização do trabalho, Ohno acabou por desenvolver a "desespecialização" e ao exigir dos trabalhadores a polivalência, tirou o poder de negociação que os mais qualificados possuíam, conseguindo assim o aumento do controle sobre a produção e a intensificação do trabalho.

Ainda na década de 1950 a Toyota incorporou a ideia de gestão de estoques praticada em alguns supermercados estadunidenses, nos quais havia a reposição rápida de artigos nas prateleiras após serem levados pelos clientes, o que confluía com o propósito da empresa de produzir o que é exatamente necessário, no tempo exatamente preciso. A adaptação foi aplicada de forma que cada trabalhador de um posto se abasteceria, quando necessário, das peças do posto anterior ao seu, de modo que a fabricação de peças nesse posto somente aconteceria em função da demanda ou da alimentação do anterior (nem mais, nem menos). Para que isso ocorresse estabeleceu-se um fluxo inverso de informações, no qual o posto posterior dava uma instrução destinada ao posto imediatamente anterior, em que a produção só se mantinha ativa com a quantidade exata de peças necessárias. Foi elaborado um dispositivo mecânico que conduzia caixas no sentido inverso da produção (dos postos posteriores para os anteriores), contendo cartazes (Kanban, no idioma japonês) com informações sobre a quantidade necessária de alimentação dos postos subsequentes, ao mesmo tempo em que outras caixas passaram a circular no sentido regular do fluxo produtivo (dos postos anteriores para os posteriores), carregadas de materiais ou peças encomendadas por cada um desses postos, em um processo definido como Sistema Kanban. (CORIAT, 1992).

Com o kanban foi possível descentralizar uma parcela das atividades relativas ao controle das encomendas e das fabricações, que antes estavam concentradas num departamento especializado no período taylorista/fordista,e agora estão confiadas aos chefes das equipes de funcionários. Essa descentralização possibilitou integrar as atividades de controle de qualidade dos produtos à própria esfera da produção direta. Essas modificações, como a descentralização de funções com trabalhadores polivalentes e o sistema de kanban, 
exigiram um novo modelo de planta fabril, com o objetivo de viabilizar a produção em fluxo contínuo, evitando o deslocamento desnecessário de trabalhadores e de insumos produtivos.

O espaço produtivo foi reformulado pela "celularização" ${ }^{26}$, que consistia em organizar os postos de trabalho em grandes conjuntos abertos (diferente dos conjuntos fechados em departamentos), que concentram em si uma etapa definida de todo o processo produtivo. Os conjuntos de postos de trabalho foram denominados "células de produção" ou "equipes de trabalho", em trabalhadores podiam alternar-se em seus postos dependendo do volume de produção exigido, das metas de qualidade a serem cumpridas ou por outros motivos. Essas "células de produção" podem contar com um líder, ao qual se atribui a função de assegurar o funcionamento perfeito dos postos e a comunicação entre as células e a administração da empresa.

\begin{abstract}
“A combinação entre autonomação, polivalência e celularização, promoveu uma realocação das máquinas por trabalhador, estabelecendo, portanto, não apenas uma nova racionalização das operações de cada posto no processo produtivo, mas uma nova sincronização dos postos e das células entre si, visando uma diminuição tanto do acúmulo de estoques em cada máquina (ou em cada célula), quanto de perdas de tempo no decorrer do transporte dos produtos ao longo da fábrica" (PINTO, 2010: 67).
\end{abstract}

A finalidade principal era estabelecer um fluxo contínuo, com uma quantidade mínima de trabalhadores e insumos em processo. O sistema do toyotismo inovou em uma das esferas fundamentais para a empresa, que foi a aplicação do sistema kanban em sua relação com as empresas clientes e fornecedoras ao longo das cadeias produtivas (kanban externo). Com isso, ao estabelecer um fluxo continuo de informações e alimentação de produtos entre essas empresas, foi possível permitir a ativação das atividades nas fábricas somente após as encomendas, as quais deviam ser feitas somente após finalizados determinados patamares de vendas. Nesse sentido, houve a formação de estoques mínimos nas empresas e uma relação muito mais estreita com a demanda do mercado consumidor.

O departamento de vendas possui a primazia de detonar o processo produtivo: somente é produzido algo se for pedido por vendas. Ocorre uma ruptura do processo produtivo do taylorismo/fordismo, com suas fábricas gigantes e enormes estoques. Nesse novo modelo organizacional a filosofia é atender ao "mercado" para depois produzir, e

${ }^{26}$ (Ver para mais detalhes: MELLO E SILVA, 2006; MELLO E SILVA, 2004). 
denominou-se just-in-time à esse novo sistema de encomenda-produção-entrega pontual. Seu significado é mais abrangente que sua tradução literal (no tempo certo), carregando o conceito de produzir somente o que é necessário (com as devidas especificações dos clientes), na quantidade necessária e no momento necessário (nem antes, para evitar a capacidade produtiva ociosa, nem depois).

No sistema toyotista a produção é "puxada". O que importa é o tempo do "ciclo de atividades" efetuadas em cada célula e, consequentemente, em cada posto de trabalho, sendo ambos variáveis ou restabelecidos permanentemente de acordo com a variação da demanda global, ou seja, do próprio fluxo da cadeia produtiva. Já no sistema taylorista/fordista a produção é "empurrada", onde a somatória do tempo das mínimas operações de um único trabalhador era previamente fixada e determinava a capacidade produtiva do sistema como um todo.

O modelo de organização do trabalho toyotista possui uma coesão sistêmica entre diversos elementos, que ocorre na proporção direta de sua melhor aplicabilidade e funcionamento como um conjunto "harmônico":

\begin{abstract}
"Pensando na relação entre clientes e fornecedores (ou mais amplamente na relação entre produção e consumo aludida acima) e considerando-se um mercado consumidor instável, diversificado e altamente concorrencial; nessas condições, uma demanda sobre a produção será de uma capacidade de pronta entrega, qual seja, o regime just-in-time. Esse regime, por sua vez, exige não somente um fluxo perfeito de informações (kanban), mas também uma capacidade produtiva flexível, para a qual se faz necessário um controle de qualidade minucioso e uma distribuição de funções que permita a cada trabalhador abranger uma totalidade de metas em pouco tempo. Isso é satisfeito pela autonomação e pela polivalência. Finalmente, o que se espera de fato, é importante que se tenha baixos custos: estes são atingidos através do controle do "estoque mínimo", isto é, a gerência do mínimo de efetivos de trabalhadores e instalações físicas necessárias a determinada escala de produção, voltada a atender exatamente determinada quantidade de consumo, sem geração de capacidade produtiva ociosa. Dai a importância da celularização da produção" (PINTO, 70: 2010).
\end{abstract}

Neste sentido, o toyotismo como modelo de organização do trabalho se enquadra em um sistema mais complexo e não está restrito ao âmbito interno das fábricas. É necessário que as "partes da engrenagem" do sistema como um todo estejam afinadas e coordenadas globalmente, desde o trabalhador, vendas, gerência, fornecedores e etc., o que pode explicar a 
dificuldade de aplicação que algumas empresas fortemente enraizadas ao modelo taylorista/fordista têm para a adoção destes novos princípios produtivos.

Um dos fatores mais significativos da aplicação do modelo toyotista é que ele superou em produtividade os demais sistemas de organização flexível, sem buscar eliminar ou minimizar o confronto entre trabalhadores e patrões nos locais de trabalho. Pelo contrário, aproveitou-se dessa situação e por meio da manipulação da subjetividade dos trabalhadores, extrai o acúmulo de conhecimentos tácitos que os mesmos adquirem, em favor do aumento da produtividade capitalista.

Uma outra estratégia utilizada para aumentar a produtividade da empresa é o critério de avaliação que recai sobre a equipe da célula de produção, de maneira que a manifestação de qualquer desinteresse, fadiga ou revolta por parte de um dos seus membros pode ser constatada como ameaça ao restante do grupo, que passará (por medo da perda do emprego) a coagi-lo pessoalmente, em nome da empresa. Essa "autoexploração" dos trabalhadores, com uma grande "responsabilização" do trabalhador pelas suas tarefas, destrói um dos pilares da construção e da formação do grupo operário no período taylorista/fordista, qual seja a solidariedade de classe: os trabalhadores passam a agir cada vez mais movidos por seus interesses pessoais em detrimento dos interesses coletivos do grupo operário, como existia em maior ou menor grau no período taylorista/fordista. (Ver para mais detalhes: DUBAR, 2009; PEREIRA, 2009).

No modelo toyotista a pressão por produtividade abrange toda a organização empresarial, desde os mais altos cargos administrativos até os funcionários operacionais. Os trabalhadores foram responsabilizados pela manutenção dos equipamentos com que trabalham, a limpeza do local de trabalho, o controle de qualidade de seus produtos, bem como por se reunirem constantemente com a administração da empresa e proporem modificações que aumentem a produtividade desta. O sistema de reuniões periódicas em que os trabalhadores discutem acerca de melhorias e soluções para os problemas da empresa é designado como Kaisen. Aos trabalhadores é dada a oportunidade de contestarem as empresas, mas a finalidade das mesmas é minimizar os conflitos e buscar aproveitar as divergências como potencial criativo para o aumento da produtividade. (CORIAT, 1994).

Da mesma forma que ocorre a aplicação do Kaisen nas empresas, também existem os Círculos de Controle de Qualidade (CQCs, na sigla em inglês), constituídos por grupos de trabalhadores reunidos periodicamente para discutir a qualidade do seu trabalho. Esses grupos 
são instrumentalizados com métodos específicos para a análise dos problemas apresentados, ensinados pela gerência, que não participa da reunião, mas recolhe as propostas ao final da mesma, podendo transformá-las em projeto ${ }^{27}$. O maior êxito dos CQCs não está na redução de custos e no aumento da produtividade, mas sim em envolver e persuadir os trabalhadores com os "valores e princípios da empresa", fazendo com que interiorizem seus objetivos como se fossem seus próprios interesses, desempenhando assim um papel fundamental na construção e conformação do consentimento, criando em alguns casos situações de confronto entre os adeptos e os contrários aos ideais das empresas.

O modelo toyotista, adotado mundialmente a partir da década de 1970 em muitas empresas, é o principal modelo de organização do trabalho alternativo ao taylorismo/fordismo. Prescreve uma profunda reorganização do trabalho internamente às plantas produtivas, além de se sustentar numa rede de subcontratação entre grandes firmas, cujas relações são muito mais fortes e estruturadas, principalmente pela aplicação do sistema just-in-time. Tem como fundamento uma metodologia de produção e entrega mais rápida e precisa que os demais modelos alternativos de organização de trabalho que se apresentavam como possibilidades diante do enfraquecimento do taylorismo/fordismo, devido exatamente, em grande parte, à manutenção de uma empresa "enxuta" e "flexível”. (PINTO, 2010).

Obteve-se êxito com este modelo focalizando-se no produto principal e gerando desverticalização e subcontratação de empresas, que passavam a desenvolver e a fornecer produtos e atividades utilizando a mão de obra polivalente e atribuindo a cada trabalhador atividades de execução, manutenção, limpeza, controle de qualidade e operação de vários equipamentos ao mesmo tempo, dentre outras responsabilidades.

O modelo organizacional toyotista adequava-se perfeitamente aos objetivos dos capitalistas, que diante de uma conjuntura macroeconômica de desequilíbrios nas contas dos países, internacionalização de investimentos em capitais financeiros e de expansão e flexibilização das fronteiras nacionais a partir da década de 1980, vislumbraram no sistema toyotista a solução para a crise e a salvação do sistema do Capital. Com isso, o modelo difundiu-se relativamente rápido nas indústrias de bens duráveis nos principais países capitalistas avançados.

${ }^{27}$ (Ver para mais detalhes: FERRAZ, 2009; GUIMARÃES \& COMIN, 1998). 
Os desequilíbrios comerciais e cambiais das economias nacionais, a crescente "autonomização" do setor financeiro especulativo diante dos Estados e dos setores produtivos e o deslocamento do consumo de bens para o consumo de serviços nos países capitalistas avançados levaram as corporações transnacionais, na década de 1970, à necessidade de repensar suas estruturas organizacionais e as formas de circulação de suas mercadorias. A difusão internacional do modelo de organização do trabalho toyotista somente pôde ser viabilizada pelo amparo jurídico e institucional dado pelos Estados nacionais às relações entre as empresas e, particularmente, entre os trabalhadores e os empresários.

Nesse sentido, todo o processo de transformações econômicas que se instaura a partir da década de 1970, denominado como reestruturação produtiva, somente pôde ser efetivado a partir de um conjunto de políticas estatais (em maior ou menor grau, dependendo do país), que flexibilizaram as barreiras institucionais para a aplicação de suas medidas e políticas, especialmente diante das consequências prejudiciais que os trabalhadores sofreram com a aplicação do modelo toyotista em seus países, particularmente nas economias periféricas ${ }^{28}$.

As ações "flexibilizadoras" dos Estados tiveram como base ajustes estruturais nas contas nacionais, afetando desde o investimento estatal nos setores produtivos e financeiros até as políticas sociais, submetendo a alocação dos recursos e dos resultados econômicos ao movimento de livre mercado. Com a reestruturação produtiva, houve, ao mesmo tempo, alterações nas políticas econômicas e sociais dos Estados nacionais, como a desestruturação do mercado de trabalho, a desregulamentação das relações trabalhistas e a flexibilização das barreiras comerciais e das antigas conexões entre as iniciativas pública e privada, configurando políticas "neoliberais" que por suas próprias características praticamente se opõem às ações propostas como ideais pelo Estado de bem-estar social ${ }^{29}$.

Em relação aos trabalhadores, foram eliminadas pouco a pouco as regulamentações protetoras dos direitos básicos e passou a vincular a ideia de que eram justamente essas regulamentações do mercado de trabalho que impediam o pleno emprego. Alguns segmentos sociais, como os empresários, afirmavam que esse "excesso" de direitos elevava os custos da produção, diminuindo a competitividade empresarial (principalmente a competição com o mercado externo). Assim, quanto mais desregulado for o mercado de trabalho, maior será o

\footnotetext{
${ }^{28}$ (Ver para mais detalhes: GALVÃO, 2003; GITAHY \& BRESCIANI, 1997; CASTRO, 1997; BRESCIANI, 1996; ARAÚJO et al, 2001).

${ }^{29}$ (Ver para mais detalhes: BOITO Jr., 2002; FERREIRA, 1997; IANNI, 1996).
} 
crescimento do nível geral de emprego, a criação de novos postos de trabalho e o "pleno emprego" (este resultante, para os defensores desse postulado, do fortalecimento das forças de concorrência, da abertura comercial e da estabilidade monetária).

Nesse processo de reestruturação produtiva, houve privatizações de empresas públicas, direitos sociais foram derrubados e a renda dos trabalhadores por meio dos salários foi reduzida, gerando um quadro de recessão em que enormes contingentes de trabalhadores foram desempregados, minando as bases dos grandes sindicatos, os quais, atingidos por fragmentações na composição da classe trabalhadora e por sua constante realocação entre distintos setores econômicos, acabaram por serem levados num processo de crise que abalou um dos principais pilares de sustentação do modelo taylorista/fordista de regulação e organização do trabalho. (Ver para mais detalhes: ANTUNES, 1998; RIFKIN, 1995).

De acordo com Rodrigues (2002), durante o período de 1970 a 1988, a sindicalização caiu de $35 \%$ para $28 \%$ no conjunto de todos os países. O recurso à greve e seus efeitos como meio de reivindicação dos trabalhadores foi afetado, tendo sua eficácia reduzida pela fragmentação do grupo operário, altos índices de desemprego e aumento da heterogeneidade que atingiu toda a classe trabalhadora. Esse contexto dificultou ainda mais a formação de uma coesão que antes permitia a organização dos trabalhadores além de suas empresas, ramos e setores de trabalho (ANTUNES, 1998).

As novas formas de organização do trabalho, as novas tecnologias, a ascensão de "valores neoliberais" e a queda de regimes do socialismo real enfraqueceram a resistência dos sindicatos frente às ofensivas das políticas neoliberais. O poder e a garantia da "paz social" que os sindicatos representaram no modelo de organização e regulação do trabalho taylorista/fordista estava em decadência. A instabilidade política, a fragmentação do grupo operário, o aumento de trabalhadores sem a proteção dos direitos trabalhistas e o crescente desemprego provocam a descentralização das ações coletivas e das negociações dos sindicatos nesse novo momento histórico. (Ver para mais detalhes: SALLUM Jr.,2005; FREDERICO, 2004).

Com a fragmentação do grupo operário, os sindicatos encontram dificuldades para articular ações e reivindicações mais amplas que ultrapassem as divisões por ramos ou atividades profissionais. As pautas ficam cada vez mais próximas de interesses de uma categoria profissional específica, de funcionários de um grupo de empresas ou de uma empresa em particular em detrimento da classe como um todo. 
O sindicalismo mundial nesse novo momento histórico passa por uma crise que fica evidente a partir dessa fragmentação da classe operária e da adoção de um sindicalismo de participação, próximo de um sindicalismo de empresa, que promove o envolvimento dos trabalhadores com a empresa em troca de certas garantias. Essa estratégia utilizada pelos empresários tem impactos significativos sobre os valores partilhados pelos trabalhadores, gerando uma redução em grande escala do conflito de classe e debilitando o movimento sindical. (Ver para mais detalhes: COMIN \& OLIVEIRA, 1999; SALLUM Jr., 2005).

Outro fator fundamental para a crise foi à ascensão de governos conservadores nos Estados Unidos e na Inglaterra, que tinham como premissa enfraquecer ou até destruir o movimento sindical presente nestes países. Na Inglaterra, o governo de Margareth Thatcher rompeu com a política de troca entre sindicatos e o Estado e adotou uma série de medidas que contestavam os direitos sociais dos trabalhadores.

No Brasil, a reestruturação produtiva foi aplicada principalmente a partir da década de 1990, embora as inovações propostas pelo modelo toyotista tivessem início ainda na década de 1980, como uma forma de garantir o mercado de exportação. Diante das dificuldades econômicas que os países capitalistas avançados estavam sujeitos na crise econômica, estes pressionaram os países endividados a pagarem as suas dívidas externas. Porém, com a elevação da taxa de juros internacional e a dificuldade de conseguir novos empréstimos, estes países foram mergulhados em uma crise da divida externa em 1982. (Ver para mais detalhes: BEDÊ, 1996; ARBIX \& ZILBOVICIUS, 1997).

O governo brasileiro da época, em um contexto de dívida externa alta, adotou a cartilha de recomendações do Fundo Monetário Internacional (FMI) para obter acesso aos recursos financeiros internacionais. Essas recomendações prescrevem a realização de reformas estruturais no país, medidas macroeconômicas de estabilização monetária, adoção de políticas econômicas neoliberais, abertura comercial e financeira, privatização do setor público e redução do Estado (GALVÃO, 1996).

Esse conjunto de ações produziu uma contração do mercado consumidor interno, incentivando as exportações, o que acarretou em estímulos a uma maior competição pelos mercados internacionais por parte das empresas nacionais e a adoção de princípios toyotistas de organização do trabalho em muitas dessas empresas (ALVES, 1998).

A aplicação da reestruturação produtiva no país envolveu uma maior automação industrial (particularmente a incorporação da microeletrônica), alteração da estrutura interna 
das empresas com a redução dos níveis hierárquicos, novas formas de organização do trabalho inspiradas no modelo de organização toyotista (principalmente a aplicação do sistema just-intime e os programas de qualidade) e a terceirização.

Apesar da aplicação de muitas medidas relativas à reestruturação produtiva nas empresas brasileiras, estas não representaram automaticamente uma mudança no modelo de organização do trabalho, mas sim um reforço às práticas do modelo organizacional taylorista/fordista, já que a automação, por exemplo, foi utilizada em muitas empresas para intensificar o ritmo de trabalho ${ }^{30}$. Houve também uma resistência dos empresários em abandonar o controle da mão de obra como previsto no modelo toyotista; a separação entre concepção e execução do trabalho se manteve em diversas empresas, as taxas de rotatividade permaneceram altas e as empresas ainda conservavam complexas estruturas de cargos e salários, longe do receituário japonês (GALVÃO, 1996).

Os efeitos da adoção da reestruturação produtiva no Brasil foram: o aumento de desemprego; precarização da mão de obra (atividades realizadas pelos trabalhadores sem o registro legal na forma de direitos trabalhista); redução dos níveis salariais dos trabalhadores; manutenção da polarização entre trabalhadores qualificados e não-qualificados; aumento do risco à saúde mental dos trabalhadores devido à intensificação do ritmo de trabalho e da pressão por qualidade total; e por fim uma pequena melhoria nas condições físicas de trabalho (redução do nível de esforço físico dos trabalhadores e da insalubridade nas empresas) (SILVA, 2010).

Ainda no final da década de 1980, a falta de eficiência por parte do Estado brasileiro para superar a crise econômica possibilitou o surgimento de um discurso antiprotecionista que enxergava na liberalização comercial e redução do papel do Estado na economia a solução para os problemas brasileiros. Esse discurso foi a base da vitória de Fernando Collor de Melo à presidência do país em 1989.

No início da década de 1990, com a abertura comercial promovida pelo governo Collor, a fragilidade da indústria nacional foi constatada com a competição externa e diante de sua possível falência as medidas da reestruturação produtiva no país foram aprofundadas. Com isso desenvolveram-se novas formas de contratação (aumento substancial do contrato de trabalho por tempo determinado ou por tempo parcial) e novas formas de pagamentos (o

${ }^{30}$ (Ver para mais detalhes: DRUCK, 1999; CORREIA, 2003; FRANCA, 2004; MATTOSO \& OLIVEIRA, 1996). 
salário foi decomposto em diversas empresas entre salário fixo e variável, que dependia dos resultados ou lucros obtidos pelos trabalhadores). Essas consequências, aliadas ao crescente desemprego, ao aumento da instabilidade e uma constante insegurança dos trabalhadores, promoveram uma refração na atividade sindical no país. Sobre o sindicalismo brasileiro faz-se necessário uma análise mais precisa do seu crescimento na década de 1980 e da sua retração na década de 1990. (Ver para mais detalhes: BOITO Jr., 1991; CARDOSO,1998).

O movimento sindical brasileiro teve um "renascimento" e crescimento no final da década de 1970 devido a vários fatores: primeiro, o "novo sindicalismo" representou a resistência aos regimes autoritários, no qual as grandes greves realizadas em 1978 e 1979 explicitaram a força do movimento sindical e a existência de uma peça política de resistência fundamental contra esse regime; segundo, a estrutura corporativa herdada da década de 1930 mostrou-se bastante flexível, sendo utilizada pelo regime autoritário como um instrumento de repressão e controle dos sindicatos, ao mesmo tempo em que se permitiu ser base de sustentação da redemocratização devido sua rápida organização coletiva por todo o país; terceiro, os sindicatos possuíam demandas por justiça e dignidade no trabalho, que permitiram o combate mais efetivo de gestões autoritárias de trabalho e o uso predatório da força de trabalho; quarto, o ambiente macroeconômico mostrou-se bastante favorável ao sindicalismo, já que as taxas crescentes de inflação tornaram racionais as estratégias contenciosas baseadas em greves de massa demandando a indexação dos salários. Essas greves econômicas tornaram-se rapidamente protestos políticos diretos contra o governo. A taxa de desemprego mantinha-se baixa, aumentando a adesão dos trabalhadores e reduzindo o temor de uma participação sindical; quinto, a crise fiscal do Estado conteve o salário real dos servidores, o que contribuiu para capitular a organização coletiva dos mesmos; sexto, pouco antes da votação na Assembleia Nacional Constituinte sobre o direito de greve, uma pesquisa sobre este assunto mostrou que a maioria dos adultos em dez regiões metropolitanas era favorável ao direito de greve para todos os trabalhadores, inclusive para aqueles designados a serviços essenciais (hospitais, serviços de transporte, bancos e etc.) (CARDOSO, 2003).

A década de 1990, pelo contrário, apresentou alguns elementos específicos da retração do movimento sindical: primeiro, com a redemocratização, as práticas e discursos contestatórios tiveram reduzido efeito, já que com o engajamento de partidos de esquerda em eleições formais com o apoio do sindicalismo houve um questionamento da legitimidade das pautas revolucionárias de parte dos líderes da Central Única dos Trabalhadores (CUT). O 
movimento sindical tinha de mudar a sua estratégia para além da pura confrontação com o "sistema político ilegítimo"; segundo, a liberalização e a facilitação de criação de novos sindicatos, dispositivos instituídos pela nova constituição, fizeram com que aumentasse o número de sindicatos sem que o emprego formal acompanhasse proporcionalmente este aumento, ou seja, havia um aumento do número de instituições (sindicatos) sem representar aumento de mobilização coletiva ou até mesmo dificultando essa mobilização; terceiro, a aplicação dos círculos de controle de qualidade (CQCs) nas fábricas diminuiu a participação sindical, pois esses sistemas de qualidade possibilitaram que os problemas da produção fossem diretamente negociados entre o trabalhador e a gerência, sem a interferência sindical, com a introdução de novas formas de organização do trabalho ao invés de uma gerência despótica. O chão de fábrica caracterizava-se pela cooperação entre os agentes da produção e, além disso, as terceirizações impuseram um forte limite ao crescimento sindical; quarto, o ambiente macroeconômico com aumento significativo das taxas de desemprego, privatização de muitas empresas estatais, crescimento nos índices de trabalho informal e queda significativa das taxas de inflação reduziu demasiadamente a propensão dos trabalhadores à ação coletiva; quinto, o sucateamento das empresas estatais e a ampla e popular campanha da mídia contra os "marajás" do serviço público enfraqueceram ainda mais uma das bases mais fortes do sindicalismo da década de 1980; e por fim como Cardoso afirma:

"O fim da inflação, o apoio geral ao plano de ajuste econômico do governo Fernando Henrique Cardoso e a emergência de insegurança estrutural no emprego devida à reestruturação econômica, ao lado da reestruturação industrial com mecanismos de controle de qualidade, minaram as bases de estratégias do tipo soma zero. O compromisso de classe parece ser a regra do jogo nos novos ambientes de trabalho" (CARDOSO, 2003: 44).

As condições ficaram piores com o ataque direto que Fernando Henrique Cardoso (FHC) fez contra o movimento sindical, seu principal expoente - a CUT, e a esquerda em geral, em que o episódio da greve dos petroleiros de 1995 talvez tenha sido o mais alusivo ataque nessa direção. Neste episódio, a Petrobrás se comprometera a repassar por meio de um acordo coletivo as perdas que os salários sofressem com a inflação no patamar de 10\%, porém o governo não cumpriu o acordo e se recusava a adotar esse tipo de indexação para qualquer categoria profissional, uma vez que estava combatendo a indexação geral da economia. Depois de negociações frustradas, uma greve de trinta dias foi duramente reprimida com o exército ocupando refinarias, a demissão de 59 líderes sindicais no Brasil inteiro e nenhuma 
reivindicação atendida. Uma derrota significativa para a CUT, já que além das reivindicações não serem atendidas em um dos principais pólos combativos do movimento sindical, a opinião pública foi contrária aos grevistas, considerando a greve injusta e realizada por motivos políticos (CARDOSO, 2003).

A partir de 1995 o governo de FHC começou a realizar um amplo processo de privatização das empresas estatais, mesmo que a opinião da maioria da população fosse contrária a essa prática. Nesse contexto, o "novo sindicalismo" em que a CUT era a principal representante enxergava pouco a pouco o enfraquecimento das suas bases de combatividade nos setores públicos e não conseguiu canalizar para si a rejeição da população em relação às privatizações. Mais do que isso, na década de 1990 a Força Sindical apresentou-se como um competidor efetivo da adesão dos trabalhadores às centrais sindicais. A Força Sindical, ao contrário de uma estratégia de confronto com o governo e com o capital, que ainda era realizada pela CUT, prega a cooperação e a parceria em nome do "bem de todos". Essa central sindical apoiou as políticas neoliberais e ganhou bastante espaço e poder sindical na década de 1990 com a ação coletiva em nível de empresa, representando um poderoso adversário na política sindical da CUT. (Ver para mais detalhes: RODRIGUES, 2007).

Outro obstáculo ao movimento sindical na década de 1990 foi o financiamento dos sindicatos, que ficou escasso diante do crescimento do desemprego e do aumento do número de trabalhadores no setor informal. As derrotas, os desafios e a ineficácia da ação sindical diante do avanço das forças do capital, pareceram emitir simbolicamente um recado de que os sindicatos, e mais propriamente a CUT, são fracos perante o capital e o governo. A ação centralizada foi minada com as mudanças profundas no ambiente econômico, político e social. "O neoliberalismo parece ter vencido não apenas uma batalha, mas a guerra política e ideológica" (CARDOSO, 2003: 50).

Na década de 1980 o sucesso do movimento sindical assentava no constante fracasso dos pacotes econômicos que buscavam controlar a inflação no Brasil. A estratégia utilizada pelo movimento sindical era de crítica e ataque a cada novo pacote econômico que o governo apresentava em contraposição ao apoio popular à medida. Ao passo que o pacote econômico não surtia o efeito esperado pelo governo, o movimento sindical realizava greves sindicais contra o pacote econômico e conquistava vitórias em relação à reposição da inflação no salário dos trabalhadores. Essa estratégia sofreu um duro golpe com o sucesso do Plano Real, 
que acabou com uma das principais estratégias sob a qual a identidade da CUT foi forjada na década de 1980, a canalização da insatisfação popular.

Por mais que os sindicatos da CUT conseguissem vitórias contra as ameaças de fechamento de plantas produtivas na indústria automobilística, com barganhas por concessão com os empresários (barganhas coletivas), eles não foram capazes de impedir a destruição de cerca de dois milhões de empregos formais na indústria, sua base de sustentação política. Também não conseguiram impedir o sucateamento e a deterioração dos serviços públicos, outra base política fundamental. As privatizações não foram impedidas, nem conseguiram estatizar as antigas empresas públicas privatizadas. As vitórias no mercado de trabalho foram parciais e localizadas em sindicatos previamente poderosos, ou seja, a CUT foi se deslocando cada vez mais para fora da cena política brasileira. Os sindicatos e as centrais sindicais perderam uma parcela importante de sua capacidade de funcionar como promotores ou representantes de identidades coletivas de caráter político. (Ver para mais detalhes: PEREIRA, 2009; ARBIX, 1998).

A CUT optou desde o seu nascimento por realizar uma pressão de "fora do sistema", sempre se apresentando como oposição ao governo e não aceitando fazer parte de concertação política com os governos. Sua tática era organizar os trabalhadores para ganhar as eleições pelo Partido dos Trabalhadores (PT) e seus aliados de esquerda, e somente a partir daí tomar parte direta no processo político institucional. Na década de 1990 esse postulado foi modificado com a participação nas Câmaras Setoriais ${ }^{31}$ (arranjos tripartites entre Capital, Trabalho e Estado), neste momento eleitas como palco principal de sua ação representativa no governo de Itamar Franco, apesar dos profundos conflitos derivados dessa posição no interior da própria CUT. Com isso, e pela primeira vez, a CUT decidiu participar do processo político institucional, reconhecendo a democracia e seus procedimentos e adotando a posição de atuar em seu interior para formular regras e normas para o uso do trabalho e para a política social, uma mudança significativa na identidade que a central sempre cultivou.

A Força Sindical, ao contrário, adotou desde o seu nascimento uma postura pragmática em relação aos projetos de governo, tendo inclusive papel ativo na implementação de políticas neoliberais. Esse apoio às políticas neoliberais tinha um duplo objetivo por parte da central: que as lideranças políticas reconhecessem e recompensassem a lealdade da Força

\footnotetext{
${ }^{31}$ (Ver para mais detalhes: ARBIX, 1996).
} 
Sindical para com eles na aplicação das medidas neoliberais, e atacar as bases sociais da CUT. Por mais que a estratégia adotada possa parecer irresponsável, já que a privatização e a reforma do Estado atacam as suas próprias bases de representação, a Força Sindical utilizou as políticas neoliberais como um marcador de diferença em relação à CUT, mesmo que para isso deixasse de representar os interesses dos seus filiados. Esse apoio da Força Sindical às medidas governistas e às políticas neoliberais obteve recompensas em termos políticos, já que suas lideranças tornaram-se políticos com muita visibilidade dada pela mídia, transitando nos ambientes políticos ao lado do presidente da república, colhendo os frutos da aprovação popular no inicio do mandato de FHC e dos primeiros anos de neoliberalismo.

O apoio às Câmaras Setoriais por parte da CUT estava assentado em uma leitura política e econômica de que a intervenção macroeconômica teria que ser realizada pelos sindicatos, ou eles estariam condenados a reações cegas diante de forças cegas e incontroláveis do neoliberalismo. O sucesso de algumas dessas câmaras, em especial a do setor automobilístico, base do principal sindicato da CUT (Sindicato dos Metalúrgicos do $A B C)$, serviu para pacificar os conflitos internos dentro da central, ao passo que com a queda desse arranjo em 1995, as correntes mais à esquerda da central que eram contrárias à medida obtiveram mais poder. Entre 1995 e 1997 a CUT perdeu proeminência como principal força de oposição ao neoliberalismo. A partir de 1999 a CUT realizou uma série de protestos e greves que foram amparadas pela crescente desaprovação do governo pela população. No entanto, a central não conseguiu recapturar seu antigo posto de principal força de oposição ao governo, compartilhando-o com outros partidos e com o Movimento dos Trabalhadores SemTerra (MST). Com a incapacidade de oferecer alternativas claras às políticas neoliberais a CUT perdeu a distinção política que antes a fizera avançar.

$\mathrm{Na}$ década de 1990 as mudanças econômicas, políticas e sociais fizeram o movimento sindical perder o espaço de influência que detinha sobre a população e evidenciaram a crise do sindicalismo que já era verificada em outros países desde a década de 1970. As centrais sindicais brasileiras não conseguiram apresentar alternativas viáveis às políticas neoliberais, que por sua vez destruíram parte de suas bases de sustentação. Ao longo dessa década os sindicatos foram deslegitimados como atores políticos stricto sensu, a democracia representativa consolidada fez surgir atores políticos especializados, profissionais, com seus próprios espaços institucionais. As tarefas políticas nessa década passaram a ser consagradas como objetos dos partidos e não dos sindicatos. Neste novo ambiente neoliberal 
o discurso prevalecente é de uma despolitização da economia, ao mesmo tempo em que as forças do mercado são aclamadas como às que guiam a política. As demandas trabalhistas estritamente econômicas não possuem mais as consequências políticas que fomentaram o poder sindical na década de 1980 e o inimigo do movimento sindical não é mais tão claramente identificável.

\subsection{A desregulamentação da legislação trabalhista}

A desregulação da legislação trabalhista ganha relevância e se realiza concomitantemente com a reestruturação produtiva e a aplicação de políticas neoliberais nos países capitalistas avançados ${ }^{32}$. A partir da mudança para um regime de despotismo hegemônico, como afirma Burawoy, ou um regime de acumulação flexível, nas análises de Harvey, se estabelece uma modificação profunda na legislação sobre os direitos do trabalho. As conquistas dos trabalhadores que se efetivam em direitos trabalhistas, como dito anteriormente, sofreram transformações em que algumas medidas que garantiam a estabilidade do trabalhador deram lugar a uma legislação que foi flexibilizada em diversos países, com a intenção de possibilitar uma resposta mais rápida do mercado às mudanças econômicas e aos interesses dos empresários no crescimento da acumulação capitalista.

No Brasil, a desregulação das leis trabalhistas é fruto do desmonte do projeto nacional-desenvolvimentista fundado nos anos 30, aprofundado na década de 1950 e rompido nos anos 80. Este modelo tinha como interesse substituir uma economia agrário-exportadora por uma economia industrial urbana, o que em boa medida conseguiu fazer. O modelo nacional-desenvolvimentista era baseado no endividamento público do Estado brasileiro para o financiamento do desenvolvimento.

$\mathrm{Na}$ medida em que se elegeu o setor público como depositário dos custos do ajustamento externo da economia, criou-se uma situação em que o Estado foi perdendo o poder que tinha de condutor do desenvolvimento, levando o país à estagnação. $\mathrm{O}$ capital privado, movendo-se por estímulos de mercado, notadamente rentáveis no curto prazo, transferiu e concentrou grande parte de sua riqueza em ativos financeiros ao invés de produtivos. Também não foi capaz de ocupar o espaço do setor estatal com o objetivo de

${ }^{32}$ (Ver para mais detalhes: POCHMANN \& MORETTO, 2002; NORONHA, 1998; DIEESE, 2005). 
redirecionar o sentido do desenvolvimento, fundando um novo pacto político apto a dar conta da superação da crise e da inflação que assolava o país.

Os empresários criticavam esse projeto nacional-desenvolvimentista, pois consideravam excessiva a carga de contribuições associadas ao trabalho assalariado formal (que segundo alguns cálculos podia chegar a 100\% do salário-base) e pelo fato de existir uma excessiva proteção legal ao trabalhador que dificultava a demissão, caracterizando um estimulo à subcontratação e à contratos de trabalhos precários (sem a proteção legal). Os trabalhadores formais estavam "caros" e era mais favorável para o empregador contratar do mercado informal, já que era possível manter somente trabalhadores essenciais e buscar o restante nas margens do mercado formal. Os empresários afirmavam que a regulação menos rígida do trabalho poderia diminuir a distância entre os setores formal e informal.

Já os sindicatos reconheciam a diferença entre os mercados de trabalho formal e informal, constatando um crescimento preocupante deste último em relação ao primeiro. Porém, sua solução para acabar com essa diferença ou diminuí-la substancialmente era a aproximação das condições de trabalho dos trabalhadores formais para os trabalhadores informais, ou seja, levar o padrão do contrato de trabalho formal com direitos e benefícios adquiridos pelos trabalhadores formais para os trabalhadores informais, e não o contrário, como argumentavam os empresários.

Com o desmonte do projeto nacional-desenvolvimentista, que apresentava uma relativa estabilidade dos trabalhadores no local de trabalho, semelhante à conquistada pelos trabalhadores nos países avançados do capitalismo na época, houve também uma desestruturação do mercado de trabalho ${ }^{33}$ que se refletiu a partir de seis fenômenos interligados, como afirma Cardoso Junior:

"Primeiro, no perfil setorial das ocupações urbanas localizadas no terciário
(comércio e serviços). Segundo, no alargamento dos segmentos considerados
pouco estruturados do mercado de trabalho (trabalhadores sem carteira
assinada, pequenos empregadores, trabalhadores por conta própria e
trabalhadores não remunerados). Terceiro, na tendência à precarização ou
perda de qualidade dos postos de trabalho (desassalariamento formal, perda
de direitos sociais, trabalhistas e previdenciários, jornadas de trabalho mais
longas, remuneração oscilante no tempo, múltiplas fontes de rendimentos,
etc.). Quarto, na estagnação das remunerações provenientes do trabalho, em

33 (Ver para mais detalhes: POCHMANN, 1998; RAMALHO \& MARTINS, 1994; CAMARGO, 1996; BARROS, 1995; JATOBA \& ANDRADE, 1993; KREIN, 2007; COMIN, 2001). 
particular dos segmentos assalariados da estrutura ocupacional. Quinto, na piora distributiva funcional (repartição da renda entre rendimentos do capital e do trabalho) e pessoal (repartição dos rendimentos do trabalho entre os ocupados). Um sexto elemento desestruturador do mercado de trabalho - o aumento dos níveis de desocupação e desemprego aberto - viria se manifestar com maior intensidade somente nos anos 90, incorporando-se a partir daí no conjunto de fatores a caracterizar empiricamente o fenômeno da desestruturação do mercado de trabalho brasileiro" (CARDOSO JR., 2001: $33)$.

Dentre os seis fenômenos descritos acima, os cinco primeiros já vinham se manifestando como algo estrutural desde a década de 1980, ao mesmo tempo em que o desemprego se manifestou com mais intensidade na década de 1990. No entanto, o desemprego ao se tornar um problema estrutural alimentou e aprofundou a desregulação que ocorria em todo o mercado de trabalho. Em outras palavras, a construção de direitos trabalhistas e a regulação do mercado de trabalho no Brasil se dão basicamente entre as décadas de 1930 e 1980, a partir de quando tem início uma fase de reversão e perda coletiva de direitos, dentro da qual ultimamente situam-se os marcos da desregulação do trabalho no Brasil.

A desregulação do trabalho no Brasil foi realizada por distintos governos, de orientações políticas diferentes. O comportamento de ambos tem se pautado pela delegação aos "agentes" (Capital e Trabalho) da definição da nova legislação trabalhista, já que ambos admitiam que a Consolidação das Leis do Trabalho era anacrônica e deveria ser substituída ${ }^{34}$. O bipartidarismo era considerado fundamental para os empresários e para os trabalhadores, já que a interferência estatal é considerada prejudicial aos empresários e também para a CUT (Central Única dos Trabalhadores), principal central sindical do país, que considerava um obstáculo a interferência estatal e queria resguardar uma distância formal do governo para afastar a imagem do antigo sindicalismo corporativista, que se criou justamente pela sua ligação com o governo.

Por mais que as medidas da desregulação do trabalho no Brasil tenham sido feitas pelo poder executivo, elas têm uma ligação com a postura do "novo sindicalismo" que tinha como reivindicação histórica a autonomia dos sindicatos em relação ao Estado (oposição ao modelo corporativista) e uma negociação direta entre Capital e Trabalho. Contudo, o novo contexto econômico de reestruturação produtiva e proeminência do neoliberalismo no mundo

${ }^{34}$ (Ver para mais detalhes: CASTRO \& COMIN, 1998). 
se mostrou desfavorável aos trabalhadores. As medidas de reforma do trabalho realizadas a partir da década de 1990 vieram do poder executivo no sentido de forçar a negociação, enquanto que no passado, o executivo forçava a regulamentação.

Essa desregulação pode ser dividida em dois processos que são combinados: a desestruturação do mercado de trabalho e a desregulamentação das relações de trabalho. A primeira diz respeito à reversão da consolidação e do avanço das relações capitalistas de produção no Brasil, basicamente a difusão do assalariamento da força de trabalho e a sua aceitação pela sociedade. A segunda diz respeito ao retrocesso dos avanços da progressiva regulamentação do mercado de trabalho, que se estabelece a partir de uma interferência pública mediadora e disciplinadora das relações e condições de trabalho.

A estruturação do mercado de trabalho depende do modelo de desenvolvimento capitalista que uma sociedade específica adota. Já a regulamentação progressiva das relações de trabalho depende da variação do grau da organização social e política do país em questão e se apresenta como um conjunto de instituições públicas (estatais e civis) e normas legais que proporcionam os parâmetros mínimos de demarcação e funcionamento do mercado de trabalho, especialmente no que diz respeito ao uso da força de trabalho (regulamentação das condições de contratação, demissão e da jornada de trabalho), sua remuneração (regulamentação das políticas e reajustes salariais em geral, salário mínimo) e reprodução da força de trabalho com proteção ou assistência social aos ocupados e desempregados (regulamentação dos direitos sociais e trabalhistas, da política de previdência social, da qualificação e requalificação profissional, da ação sindical e da Justiça do Trabalho) (CARDOSO JR., 2001).

A desestruturação do mercado de trabalho que teve início na década de 1980 não se restringiu às transformações produtivas, mas foi fruto do desmonte desse projeto nacionaldesenvolvimentista, que tinha como base a concentração urbana e industrial. A desregulamentação das relações de trabalho atuou ao mesmo tempo em que a desestruturação do mercado de trabalho, principalmente por causa de governos neoliberais que assumiram o governo do país a partir da década de 1990 e flexibilizaram as relações trabalhistas. Ou seja, em paralelo à desestruturação do mercado de trabalho que se intensifica nos anos 90, é colocado em voga o processo de desregulamentação das relações de trabalho, que vem como parte complementar e indissociável de uma ampla agenda de reformas ditas estruturais por seus formuladores, das quais a reforma do Estado é uma das mais importantes. Os 
formuladores e apoiadores dessas reformas afirmavam que estas garantiriam ao país uma reconfiguração de suas relações trabalhistas, permitindo uma competição mais viável no mercado exterior.

O crescimento significativo de desempregados foi determinado por estas políticas neoliberais adotadas na década de 1990, dentre as quais estão à inserção do Brasil no circuito financeiro internacional, a liberalização comercial irrestrita, a privatização abrangente das empresas estatais, uma política monetária de estabilização econômica, uma reforma tributária fixada à disciplina fiscal, com redução e focalização dos gastos públicos, entre outras medidas.

A partir dessa política econômica seguida na década de 1990, o Brasil sofreu um processo de desindustrialização, desnacionalização e concentração da população. Este processo está associado direta ou indiretamente ao desemprego no Brasil e à estagnação econômica. O pagamento da divida externa e a política de estabilização econômica aplicadas no inicio desta década contribuíram para o crescimento do desemprego no país, já que o pagamento da dívida levou a cortes dos gastos públicos em setores sociais, de infraestrutura e produtivos e a estabilização econômica foi realizada por meio da valorização da moeda e do crescimento das taxas de juros. (Ver para mais detalhes: NAVES, 2002).

A partir do ponto de vista do mercado de trabalho, com o movimento de abertura externa e a recessão doméstica no início dos anos 1990, houve aumento dos setores ligados aos serviços prestados às empresas, comércio e transportes (serviços distributivos), serviços prestados às famílias (serviços pessoais) e serviços não mercantis (serviços diversos). Também cresceram as inserções ocupacionais dos trabalhadores sem carteira, trabalhadores autônomos e trabalhadores não remunerados. Nesta perspectiva, as novas inserções setoriais refletem a perda de dinamismo econômico da estrutura produtiva brasileira e uma nova estratégia dos trabalhadores para a sua sobrevivência diante do colapso do emprego formal com proteção social. Tanto a terceirização ${ }^{35}$ das ocupações quanto a informalização das relações de trabalho auxiliam na explicação sobre a deterioração da qualidade da maioria dos novos postos de trabalho abertos.

Na década de 1990 é possível constatar uma precarização das relações e condições de trabalho, sendo que é razoável afirmar que entre os assalariados sem carteira assinada, a

${ }^{35}$ (Ver para mais detalhes: MARCELINO, 2002; BALCÃO, 2000). 
ausência de mediação institucional do Estado torna-os mais frágeis, bem como promove a assimetria das relações entre capital e trabalho, favorecendo uma flexibilidade quantitativa (dispensa e contratação de mão-de-obra) muito elevada, que apenas serve para engendrar uma alta rotatividade de trabalhadores nestas ocupações. A ausência ou precariedade dos mecanismos de proteção social do Estado tende a transferir aos âmbitos familiar e individual a responsabilidade pela sobrevivência social, individualizando as relações de trabalho. O que acarreta em ausência de contribuição previdenciária dos trabalhadores com menos rendimentos e em os pequenos negócios não serem registrados nas administrações públicas. As altas taxas de desemprego agiram de forma estratégica na pressão para que os trabalhadores aceitassem as inovações técnicas e organizacionais e o ritmo mais intenso de trabalho promovido pelas empresas. O desemprego tem ligação direta com a precarização das relações e condições de trabalho já que atua como fator de cooptação e repressão junto aos trabalhadores.

A desregulamentação das relações de trabalho passou por dois momentos distintos no Brasil. O primeiro momento na década de 1980, com o processo de redemocratização do país e contando com a força de movimentos sindicais e sociais, quando o Brasil viveu um período de regulamentação das relações de trabalho, com a adoção de novos direitos sociais e trabalhistas, que teve o seu ápice na promulgação da Constituição Federal em 1988. Neste momento foi possível a participação da sociedade civil com ações políticas de seu interesse, que até aquele momento havia sido deixada de lado pelo regime autoritário que vigorava no país. Essas medidas de regulamentação serviram como contraponto de um contexto econômico de crise e desestruturação do mercado de trabalho.

O segundo momento, a partir da década de 1990, particularmente a partir de 1994, tem inicio no processo de desregulamentação das relações de trabalho, que tinha como objetivo principal a modificação gradual e pontual de itens importantes da legislação trabalhista e social consagrada na Consolidação das Leis do Trabalho e na Constituição de 1988. Esta modificação se estabeleceu por meio de medidas provisórias, emendas constitucionais, portarias e decretos, todos objetos de menor resistência política de movimentos sociais e sindicais. Constituiu uma estratégia deliberada do governo federal, que contou com a aliança de determinados grupos sociais de grande expressão (empresários e parte do sindicalismo de resultados), com ligação direta com as diretrizes mais gerais da reforma do Estado no Brasil. Na implementação de políticas neoliberais houve maior ou 
menor resistência por parte de setores dominantes da burguesia, o que não ocorreu com a desregulamentação das relações de trabalho, em que todos os setores dominantes estavam unidos para retirar os direitos dos trabalhadores. (Ver para mais detalhes: OLIVEIRA et al, 2010; BOITO Jr., 1999).

A desregulamentação das relações de trabalho no país foi realizada por meio de mudanças na legislação que regulamenta o uso e a remuneração da força de trabalho. Esta desregulamentação não avançou tanto quanto a desestruturação do mercado de trabalho, mas teve influência determinante na fragmentação da classe trabalhadora, na própria desestruturação do mercado de trabalho, na individualização das relações de trabalho e no crescimento da concorrência entre os próprios trabalhadores.

Para uma apreensão mais geral do que significou a aplicação da desregulamentação das leis do trabalho, faz-se necessário demonstrar quais foram as principais medidas legais que envolveram a sua aplicação empírica no país. Apresentam-se, desta maneira, as medidas que modificaram as condições do uso da força de trabalho, aquelas que modificaram as condições de remuneração da força de trabalho, as que modificaram as condições de proteção e assistência social aos trabalhadores e, por fim, as principais mudanças relativas à reforma sindical e trabalhista (CARDOSO JR., 2001).

Entre as medidas que modificaram as condições do uso da força de trabalho é possível elencar historicamente a sua aplicação a partir de 1994. As condições do uso da força de trabalho dizem respeito à contratação e demissão da força de trabalho e às condições que regulam a jornada oficial de trabalho no Brasil. A primeira medida foi editada em dezembro de 1994, a Lei $\mathrm{n}^{\circ}$ 8.949, conhecida como a lei das cooperativas. Esta lei afirmava a inexistência de vínculo empregatício entre as cooperativas e seus associados. Assim os trabalhadores não tinham acesso a direitos trabalhistas dos trabalhadores formais, como o $13^{\circ}$ salário, férias, previdência social e descanso mensal remunerado.

A Lei $\mathrm{n}^{\circ} 9.601$ de janeiro de 1998 abriu a possibilidade do contrato de trabalho por tempo determinado, permitindo sua existência desde que em acréscimo aos postos de trabalho já existentes, por um período de até 24 meses, obedecendo aos seguintes limites: $50 \%$ dos trabalhadores, para empresas com até 50 empregados; 35\% dos trabalhadores, para empresas entre 50 e 199 empregados, e $20 \%$ para empresas com mais de 200 empregados. Além disso, durante 18 meses, os contratos por tempo determinado teriam diminuídos em $50 \%$ as alíquotas das contribuições sociais destinadas ao sistema "S"(SESI, SENAI, SENAT, SESC e 
etc.), ao SEBRAE, INCRA, salário-educação e financiamento do seguro de acidentes de trabalho. Também se reduziria de $8 \%$ para $2 \%$ a contribuição patronal ao FGTS, além do não pagamento, pelo empregador, da multa de $40 \%$ sobre o saldo do FGTS do trabalhador no momento da rescisão do contrato de trabalho. Por fim, haveria uma redução no preço das horas extraordinárias realizadas sob a vigência de contratos de trabalho por tempo determinado (CARDOSO JR., 2001).

Por meio da Lei $\mathrm{n}^{\circ} 9.601$ e uma alteração no artigo $\mathrm{n}^{\circ} 59$ da CLT foi possível a criação do Banco de Horas, que estabelece a possibilidade de o trabalhador exceder as horas de trabalho sem o acréscimo no salário. Por força de acordo ou convenção coletiva de trabalho, o excesso de horas de um dia tem de ser compensado pela correspondente diminuição em outro dia, de maneira que não exceda, no período máximo de 120 dias, à soma das jornadas semanais de trabalho previstas, nem seja ultrapassado o limite máximo de dez horas diárias. O Banco de Horas, embora fosse um desejo sindical antigo, acaba por servir, como instrumento de ajuste das horas trabalhadas às condições de curto prazo do mercado e das empresas, na medida em que não vêm acompanhadas por um processo de redução da jornada de trabalho. É uma importante medida da desregulamentação das leis do trabalho, que a pesquisa analisará de modo mais detalhado no item seguinte.

A Medida Provisória 1.709 de agosto de 1998, além de ampliar o prazo para a compensação das horas extras de quatro meses para um ano, regulamentou o trabalho por tempo parcial, permitindo, assim, uma jornada de até 25 horas semanais. Essa mudança de regime de trabalho vale tanto para novas contratações, como para os atuais empregados, desde que eles optem por este novo regime. Se a pessoa trabalhar 25 horas por semana, seu salário será $60 \%$ do salário integral e suas férias podem ser reduzidas a oito dias por ano.

A Medida Provisória ${ }^{\circ} 1.522$ de dezembro de 1997, modificou a situação dos servidores públicos, pois autorizou sua demissão conforme critérios estabelecidos em regulamento, segundo o de interesse da administração federal. Os servidores exonerados devem receber indenização de um mês de remuneração por ano de efetivo exercício no serviço público federal e os cargos vagos em decorrência da exoneração ficam automaticamente extintos. Também no âmbito do serviço público, a Lei Complementar $n^{\circ} 96$ definiu os limites para as despesas com pessoal, conforme o artigo $n^{\circ} 169$ da Constituição, modificado pela Emenda Constitucional ${ }^{\circ} 19$ de junho de 1998. Para tanto, ela disciplina em seu artigo $1^{\circ}$ que as despesas com pessoal não podem ultrapassar 50\% da receita corrente 
líquida no caso da União, $60 \%$ da receita corrente líquida no caso dos estados e do Distrito Federal, e $60 \%$ da receita corrente líquida municipal. Estes limites foram reafirmados mais tarde na chamada Lei de Responsabilidade Fiscal, aprovada em 2000 por meio da Lei Complementar $\mathrm{n}^{\circ}$ 101. A Lei de Responsabilidade Fiscal estabelece, para os entes federados que não estiverem dentro destes limites, as condições em que se cortarão gastos, definindo também as sanções aos que ultrapassaram os limites colocados em lei. Obriga, ainda, o demonstrativo de execução orçamentária do mês e do acumulado dos 12 meses anteriores, com os valores e a forma de cálculo dos mesmos, das receitas correntes líquidas e das despesas totais com pessoal.

O artigo 169 da Constituição Federal com regulamentação por meio da Lei n ${ }^{\circ} 9.801$ de junho de 1999, possibilita a perda de cargo público por excesso de despesa, prevendo, assim, a exoneração de servidores estáveis e as condições para tal. A Lei n 9.962 de 2000 estabelece que os admitidos na categoria emprego público serão regidos pelas normas da Consolidação das Leis do Trabalho e a Medida Provisória n 1.970 regulamentada em 2000, institui o Programa de Desligamento Voluntário (PDV), a jornada de trabalho reduzida com remuneração proporcional e a licença sem remuneração com incentivo pecuniário. Essa Medida Provisória destina-se aos servidores submetidos ao RJU da União Federal, sendo que as duas últimas medidas representam novas modalidades de flexibilização da legislação trabalhista implementada no setor público, assim como também vem sendo aplicada para os trabalhadores do setor privado.

Com a eleição de governos que começaram a aplicar políticas neoliberais e a desvincular o Estado da negociação que existia entre Trabalho, Capital e Estado na definição da política salarial, em nome de uma negociação direta entre patrões e trabalhadores, surgiram as medidas que modificaram as condições de remuneração da força de trabalho, retratando as transformações que a remuneração dos trabalhadores sofreu desde 1989.

A primeira medida aplicada, e a mais importante nesta pesquisa, é a Participação nos Lucros e Resultados (PLR) das empresas por parte dos trabalhadores, sem ligação com a remuneração contratual do trabalhador com a empresa. Essa medida foi editada em 1994 pela Medida Provisória n ${ }^{\circ}$ 794. A PLR depende de uma negociação coletiva entre trabalhadores e empresa e sua periodicidade de negociação não pode ser inferior a 6 meses para não substituir a remuneração contratual mensal. A partir desta Medida Provisória o governo possibilitou deixar a transferência de recursos das empresas para os empregados mais barata e com menos 
encargos trabalhistas, já que o valor correspondente da PLR não entra no cálculo das contribuições e direitos trabalhistas a serem gastos pelas empresas. A PLR será analisada e discutida de maneira aprofundada no próximo item desta dissertação, já que esta medida modificou profundamente a relação entre os trabalhadores, principalmente por passar a atuar como uma forma de se obter o consentimento dos trabalhadores em muitas empresas do país.

A Medida Provisória $\mathrm{n}^{\circ} 1.053$ de junho de 1995 modificou as formas tradicionais de reajuste salarial. Mesmo que esta medida assegurasse a permanência da negociação coletiva para o reajuste salarial, ela retirou qualquer cláusula de reajuste ou correção salarial automática, promovendo uma desindexação salarial. Esta Medida Provisória também tornou possível a adoção imediata do efeito suspensivo dos acordos, o que permite a uma das partes recorrer da decisão de um tribunal de instância inferior.

Em 1997, a Medida Provisória $\mathrm{n}^{\circ} 1.906$ veio reforçar as modificações implementadas pela Medida Provisória $\mathrm{n}^{\circ}$ 1.503, já que anunciou o salário mínimo de $\mathrm{R} \$$ 120,00 e ao mesmo tempo também o desvinculou da possibilidade de correção automática por qualquer índice de reposição da inflação, estipulando uma tabela de reajustes para os benefícios previdenciários que utilizava uma referência sem qualquer relação com a reposição salarial ou do custo de vida. Assim, o salário mínimo passou a ser definido no mês de Maio de todo ano pelo Executivo do país. Em 2000, o projeto da Lei complementar $n^{\circ} 113$ definiu que a União delegaria aos Estados a responsabilidade pela fixação do piso salarial, que não poderia ser inferior ao salário mínimo nacional do ano em vigor.

Quanto às medidas que modificaram as condições de proteção e assistência social aos trabalhadores, estas legislam a respeito tanto dos trabalhadores ocupados quanto sobre os trabalhadores desempregados. Essas medidas não necessariamente legislam no sentido de melhorar as condições dos empregados, já que em 1995 por meio da Portaria ${ }^{\circ} 865$ houve um afrouxamento da fiscalização do trabalho, determinando aos fiscais do trabalho apenas comunicarem ao Ministério Público os casos de incompatibilidade entre as condições de trabalho compactuadas em convenção ou acordo coletivo e a legislação relacionada, ao invés de multarem a empresa, como mandava a prática precedente.

Com a Medida Provisória ${ }^{\circ} 1.726$ de 1998, obteve-se a possibilidade de suspensão temporária do contrato de trabalho para a qualificação do trabalhador. Essa suspensão pode ser de 2 a 5 meses, desde que esteja prevista em acordo ou convenção coletiva e tenha aceitação formal do trabalhador. Durante a suspensão, o trabalhador tem o dever de participar 
de cursos ou programas de qualificação profissional oferecidos pelos empregadores e receberá bolsa de qualificação profissional custeada pelo Fundo de Amparo ao Trabalhador (FAT).

A Medida Provisória $n^{\circ} 1.779$ de junho de 1999 prorroga por período indeterminado a suspensão do contrato de trabalho para qualificação profissional, desde que prevista em acordo ou convenção coletiva e com aceitação formal do trabalhador, e determina que o empregador terá de arcar com o ônus correspondente ao valor da bolsa de qualificação profissional. A partir deste novo procedimento, a não existência de obrigação do empregador perante os custos da requalificação de seus funcionários está garantida apenas pelo período de 2 a 5 meses, como fixado na Medida Provisória precedente.

Algumas medidas podem ser consideradas como positivas da perspectiva dos trabalhadores, como é o caso dos programas dirigidos à geração de emprego e renda, das medidas de combate à discriminação de gênero e da que estende os benefícios do FGTS aos trabalhadores domésticos. Em 1996 foi criado o Proemprego I pela Resolução $n^{\circ} 103$ do CODEFAT e mais tarde, em 1999, pela Resolução $n^{\circ} 207$ do CODEFAT foi criado o Proemprego II. Estes programas tinham como objetivo preservar e expandir as oportunidades de trabalho, aumentar a renda do trabalhador, proporcionar a melhoria da qualidade de vida da população, em especial das camadas mais pobres, e proporcionar a redução dos custos de produção no contexto internacional.

Em 1998 foi criado o programa Protrabalho pela Resolução n 171 do CODEFAT e, posteriormente, o Protrabalho II em 1999 pela Resolução n 210 do CODEFAT, que tinham como objetivo a promoção do desenvolvimento regional. A Lei $n^{\circ}$ 9.799, editada em 1999, estabelecia a proibição de publicar anúncio de emprego fazendo referência a cor, sexo, idade ou situação familiar, assim como recusar emprego ou promoção com base em alguns desses atributos, salvo quando a natureza da atividade seja incompatível. Ficou vedado também o uso de qualquer desses atributos como variáveis determinantes da remuneração, formação profissional ou para fins de ascensão profissional.

A Medida Provisória $n^{\circ} 1.986$, sancionada em 2000, que acrescentou dispositivos a lei $\mathrm{n}^{\circ}$ 5.859, possibilitou o acesso de empregados domésticos ao FGTS. Assim, o trabalhador doméstico que for dispensado sem justa causa terá direito ao benefício do seguro desemprego, no valor de um salário mínimo, por um período máximo de três meses, de forma ininterrupta ou alternada. O benefício será concedido ao empregado inscrito no FGTS que tiver trabalhado como doméstico por um período mínimo de 15 meses nos últimos 24 meses contados da 
dispensa sem justa causa e será pago com recursos do Fundo de Amparo ao Trabalhador (FAT).

Por fim, as principais mudanças relativas à reforma sindical e trabalhista têm início em 1996 com a Lei $n^{\circ}$ 1.802, que acrescentou dispositivos à Lei de Greve (Artigo $9^{\circ}$ da Constituição Federal, Lei n 7.783 de 1989), dentre os quais se destacam os que atribuem aos sindicatos a responsabilização total pelas greves, estabelecendo multas de 500 a 1.000 salários mínimos por dia àquele sindicato que desobedecer a decisão judicial de abusividade de greve. O valor da multa varia de acordo com a condição econômica do sindicato e esta pode ser revogada se não houver outra greve abusiva dentro de cinco anos. No Decreto $\mathrm{n}^{\circ} 2.066$ de 1996 o governo limita o número de licenças concedidas a servidores públicos para o cumprimento de mandato em cargo de direção ou representação em confederações, federações e associações. A primeira medida estabelece o cerceamento do direito de greve e a outra incentiva a não mobilização sindical dos servidores públicos.

A Lei n 3.003 de 1997 estabelecia a redução do número de contribuições sindicais com o fim da taxa assistencial, mas mantinha a mensalidade dos associados, criando a chamada contribuição negocial. Essa contribuição seria descontada na folha salarial, em até três vezes, de acordo com o valor estabelecido em assembleia geral. Ela não deixaria de ter caráter obrigatório, mas os trabalhadores poderiam optar pelo seu não recolhimento, desde que aprovado por uma assembleia de pelo menos $10 \%$ dos trabalhadores, sindicalizados ou não. Os trabalhadores não sindicalizados seriam obrigados a contribuir da mesma forma que os associados. O sindicato, por sua vez, cuidaria dos interesses de toda a categoria, incluindo sindicalizados e não sindicalizados.

A Proposta de Emenda Constitucional $n^{\circ} 623$ de 1998, teve como objetivo realizar uma mudança significativa na organização dos sindicatos brasileiros, dando nova redação aos $\operatorname{artigos} 8^{\circ}, 111^{\circ}$ e $114^{\circ}$ da Constituição Federal. A mudança principal elimina a representação sindical única (unicidade sindical) em uma área territorial, abrindo a possibilidade de que mais de um sindicato concorra pela representação de uma categoria ou grupo de trabalhadores num mesmo município. Por meio da nova proposta, os sindicatos deixam de ser representantes de uma categoria por sua natureza, e passam a representar somente os interesses de seus associados. Foi prevista também uma alteração na forma legal de institucionalização dos sindicatos. A proposta prevê o fim da necessidade de registro do sindicato em órgão competente do poder público (representação sindical), exigindo somente o 
registro como pessoa jurídica na forma da lei civil. Esta Proposta de Emenda Constitucional ainda prevê a criação do Conselho da Justiça do Trabalho, a funcionar junto ao Tribunal Superior do Trabalho (TST), e cuja incumbência é exercer a supervisão administrativa e orçamentária da Justiça do Trabalho, em primeiro e segundo graus.

Em 2000 a Lei ${ }^{\circ} 9.957$ acrescenta à Consolidação das Leis do Trabalho uma seção que prevê a implantação do procedimento sumaríssimo para dissídios individuais, cujo valor não ultrapasse 40 salários mínimos. Essa mudança tem como objetivo tornar rápida e ágil a solução para demandas processuais trabalhistas individuais de baixo valor. O processo sumaríssimo reduz procedimentos burocráticos, prazos legais e define que as demandas serão instruídas e julgadas em audiência única, visando sempre à conciliação e o acordo entre as partes em litígio. As demandas da administração pública foram excluídas da possibilidade de serem submetidas a este procedimento.

A lei $\mathrm{n}^{\circ} 9.958$ de 2000, também teve a finalidade de reduzir a quantidade de processos na Justiça do Trabalho, já que autoriza as empresas e os sindicatos a criarem Comissões de Conciliação Prévia com a finalidade de tentar conciliar os conflitos individuais de trabalho, evitando que conflitos passíveis de solução extrajudicial cheguem à Justiça do Trabalho. Toda comissão formada deve ter composição obrigatoriamente paritária, com representantes dos trabalhadores e dos empregadores, totalizando no mínimo dois e no máximo dez membros. A comissão pode ser constituída no âmbito de uma única empresa e seus empregados, ou por um grupo de empresas e ter caráter intersindical. Com a comissão, todas as demandas de natureza trabalhistas serão submetidas a ela.

Essas medidas tomadas no campo da reforma sindical e da Justiça do Trabalho têm como objetivo, sobretudo, estimular a negociação direta entre patrões e empregados, modificando a organização sindical e reduzindo os custos processuais e de intervenção da Justiça do Trabalho na resolução dos conflitos de natureza trabalhista. Com a adoção do neoliberalismo no Brasil na década de 1990, as centrais sindicais tornaram-se ainda mais dispensáveis na elaboração da política econômica do país, não havendo sua necessidade como garantidoras da "paz social”. A crise econômica, o desemprego, a crise industrial e a repressão às greves sindicais, como a dos petroleiros em 1995 se incumbiam desse papel. O Estado assumiu a definição da política econômica trabalhista e social destruindo a possibilidade de estabelecer-se a paz social, como aconteceu no período fordista dos países capitalistas avançados, em que havia a integração do Estado, Capital e Trabalho. 
A partir da proeminência do neoliberalismo nos países capitalistas avançados, o neocorporativismo (Estado, Capital e Trabalho) perdeu força, uma vez que era incompatível com a grande regulação do processo de trabalho, a flexibilidade do mercado de trabalho e o poder operário. No Brasil, não se tratava de destruir uma construção institucional tripartite, já que os sindicatos não tinham assento em um organismo tripartite; para os ideólogos do neoliberalismo o que se deveria evitar era a construção do neocorporativismo no país.

A Consolidação das Leis do Trabalho (CLT) atuou como um seguro aos trabalhadores diante da total dizimação de qualquer influência sindical na ajustamento das políticas sociais, garantindo-lhes alguns benefícios. A transição que a CUT desejava do corporativismo estatal para o corporativismo societal (neocorporativismo) não se realizou, principalmente por causa do neoliberalismo, onde qualquer organização coletiva era caracterizada como inimiga do bem público. Para os sindicatos, a noção dominante era "melhor ficar com alguma coisa (CLT) do que não ficar com nada", e, em termos práticos, a investida dos empresários era para retirar direitos dos operários.

Para a principal central sindical do país (CUT), a Consolidação das Leis do Trabalho (CLT) passou a ser vista como a mais protetora para o salário, o emprego e as condições de trabalho, o que foi designado pelos empresários como uma atitude retrógrada e conservadora que atuava no sentido de impedir a competição desejável nos mercados internacionais. $\mathrm{O}$ principal argumento dos empresários era que essa proteção, que era mantida como resquício da era de substituições das importações, escondia níveis de produtividade muito baixos nos principais setores. A acumulação capitalista, para os empresários, deveria passar do Estado para o mercado, e para isso era essencial a reorganização das empresas com novos padrões de qualidade dos produtos. (Ver para mais detalhes: ANTUNES, 1998; ALVES, 1998).

A desregulamentação das leis trabalhistas instituiu novas relações de trabalho no país, em beneficio dos pequenos empresários como também do grande capital. Permitiu uma maior facilidade de contratação, demissão e de aumento da jornada de trabalho, circunstância que desemboca no rebaixamento do custo da força de trabalho. A desregulamentação e o funcionamento da economia formaram as condições gerais da exploração e controle dos trabalhadores (fruto de uma mudança na correlação de forças entre as classes sociais nos anos de 1990), efetivadas nos locais de trabalho conforme a sua localização, a posição da empresa no mercado de trabalho e a tradição política dos trabalhadores e dos empresários. 
As medidas da desregulamentação das leis trabalhistas e a desestruturação do mercado de trabalho alteraram significativamente a condição operária, já que formam a base para o rompimento da já relativa estabilidade que os trabalhadores formais tinham no Brasil. A desregulamentação das leis trabalhistas modificou a condição operária, pois permitiu a fragmentação da classe trabalhadora, a individualização das relações de trabalho e o crescimento da concorrência entre os próprios trabalhadores. Algumas de suas medidas, como será visto adiante, tiveram ampla recusa do Sindicato dos Metalúrgicos de São José dos Campos e Região, enquanto outras, porém, foram aplicadas e o sindicato teve, em alguns casos, que se adaptar à presença dessas novas medidas nas empresas para preservar os interesses dos trabalhadores que representam.

\subsection{Participação nos Lucros e Resultados (PLR) e Banco de Horas}

A Participação nos Lucros e Resultados foi instituída no Brasil em 1994 com o intuito de substituir a política salarial do governo, que indexava o assalariado de eventuais perdas com a inflação. A política salarial possibilitava a reposição de parte das perdas dos trabalhadores anualmente devido a reajustes automáticos. Essa política salarial que existia permitia aos trabalhadores reivindicar legalmente, caso não fossem repostas, as perdas no salário decorrente da inflação.

Já com a livre negociação, a responsabilidade acabou sendo transferida para as partes sem a interferência do governo. Ela tinha pressupostos pluralistas de uma escolha individual, entre as partes, ao contrário de uma medida neocorporativa (Estado, Capital e Trabalho). Acabou existindo uma "coalizão de interesses" entre o setor mais organizado dos trabalhadores e os empresários que favoreceram os últimos, pois muitas categorias tinham sindicatos fracos ou até não estavam filiados a uma central sindical, tendo pouco poder de barganha para com os empresários. (Ver para mais detalhes: KREIN \& SANCHES, 2004; DIEESE, 2000).

A partir de 1994, o governo de Fernando Henrique Cardoso propõe a livre negociação, supostamente se apoiando na reivindicação do "novo sindicalismo" de liberdade sindical e negociação direta. A livre negociação e a negociação coletiva eram reivindicações históricas do novo sindicalismo e estavam assentadas no direito "coletivo" de escolha ao contrário de uma escolha individual com pressupostos pluralistas como foi aplicada. 
A Força Sindical, principal central sindical concorrente da CUT, afirmava que a livre negociação como desejada pela central beneficiaria somente aos sindicatos fortes e poderia prejudicar os sindicatos mais fracos, que não têm o poder de fazer frente ao patronato. Esse argumento também é adotado em larga medida pelo sindicalismo. Como a parcela de trabalhadores sindicalizados é sempre menor do que o total de trabalhadores de uma categoria, os sindicatos representam uma minoria dos trabalhadores, assim como as centrais sindicais, que representam menos ainda uma vez que muitos sindicatos, inclusive, não estão filiados a nenhuma central sindical. Diante disso, para os defensores desse argumento, um acordo consolidado entre os trabalhadores formais mais organizados e os patrões se constituirá, necessariamente, acima dos interesses e das possibilidades dos setores menos organizados, levantando a hipótese de uma coalizão de interesses entre os sindicatos fortes e os setores empresariais mais fortes.

A modernização proposta pelo governo FHC, entretanto, tinha um papel estratégico junto com as realizações do governo: inserção na economia de mercado, extensão do contrato como relação social dominante, privatizações, competitividade como selecionador de novos talentos, redução do papel social do Estado, entre outras medidas que estariam no bojo da desejada modernização do Brasil. No sentido dessas medidas, a livre negociação que foi imposta tinha um limite para evitar a inflação, isto é, tinham um teto e não poderiam caracterizar um aumento real do salário. A partir disto, a livre negociação entre as partes instituídas a partir de dispositivos do poder Executivo, com condições claras quanto aos patamares tolerados para a realização de acordos salariais, não pode ser considerada realmente livre.

Os efeitos da adoção dessa medida na organização do trabalho estabelecem-se de maneira indireta e direta. Indiretamente porque propõe uma flexibilidade que se desvincula da política salarial e diretamente porque permite associar o rendimento do trabalho com a produtividade obtida através de métodos de racionalização da produção. A livre negociação entre as partes promove uma instabilidade diante da relativa estabilidade da política salarial que os governos anteriores adotavam. Juntamente com a Participação nos Lucros e Resultados (PLR) e o Banco de Horas, entre outras medidas, reflete a instabilidade do novo cenário político e econômico do país, em que a flexibilidade e a inconstância começam a vigorar nas relações de trabalho. Essas medidas foram defendidas por cumprirem a função de aumentar a competitividade das empresas no cenário internacional. Como afirma Mello e Silva: 


\begin{abstract}
"O novo panorama, no entanto, muito mais pró-empresa porque dentro do espírito da reestruturação produtiva e da globalização, não foi alcançado por um desenvolvimento autônomo dos principais atores coletivos (Capital e Trabalho), mas induzido abertamente pelo Estado, com um novo conjunto regulatório das relações de trabalho que inclui além da PLR, o Banco de Horas, a obrigatoriedade das Comissões de Conciliação Prévia, a possibilidade de trabalho por tempo determinado etc. Trata-se de um conjunto de medidas que visam adequar o mercado de trabalho ao ambiente de flexibilidade" (OLIVEIRA, F. et al, 71: 2010).
\end{abstract}

Os sindicatos realizaram as negociações da PLR nos lugares em que a mesma podia ser negociada, como um experimento para tentar fazer valer a livre negociação tal como a concebiam antes. Apesar da resistência de alguns setores que acreditavam na conjuntura desfavorável aos trabalhadores, porém, existia uma maioria que acreditava que não havia saída possível para os sindicatos naquele momento. Houve duas consequências advindas da negociação da PLR pelos trabalhadores e as empresas: primeiro, a PLR se aproximou da remuneração variável como queriam os empresários; segundo, a PLR tornou-se uma negociação diferenciada, não mais uma negociação coletiva, mas uma negociação no âmbito da empresa, pois estas, como afirmavam os defensores da descentralização da negociação, possuem realidades diversas que levam a uma negociação diferenciada.

A PLR ganha espaço na base da fábrica, e assim alguns trabalhadores acabam deixando a negociação salarial coletiva em segundo plano. Como há um acréscimo na renda do trabalhador isso atrai o interesse do mesmo, um componente muito individualizante da classe. Essa medida faz parte da regulamentação interna das fábricas, influenciando a política de Recursos Humanos, que utiliza métodos de gestão que se baseiam em resultados e metas dos trabalhadores para a definição das suas respectivas remunerações. Com a PLR, muitos trabalhadores com as mesmas funções recebem uma remuneração diferenciada, pois estão em empresas diferentes.

Segundo a legislação, a PLR deveria contar com representantes sindicais, o que ajudaria o sindicato a ganhar importância na fábrica onde, em alguns casos, tem dificuldade de atuar, mas isso não necessariamente ocorre na prática. Na perspectiva da CUT, a negociação referente a resultados e metas poderia levar a um crescimento na importância do sindicato dentro das fábricas, já que as comissões de fábrica ou comissões sindicais, que são espaços institucionais que possibilitariam a presença dos sindicatos internamente nas empresas, são previstas na legislação, porém não é regra. 
Neste sentido, a possibilidade de acesso ao âmbito interno das fábricas, com mais democratização nas relações de trabalho e transparência nos dados apresentados pelas empresas, foi de fundamental importância para a aceitação por parte dos sindicatos da participação efetiva na negociação da PLR. O "novo sindicalismo" rendeu-se à possibilidade de participação nas decisões das empresas e na transparência que aquela medida poderia prover aos sindicatos. Eram pautas e reivindicações históricas que este "novo sindicalismo" apresentava desde sua formação.

A PLR acabou por substituir a campanha salarial, inclusive fazendo parte das reivindicações dos sindicatos. Os acordos salariais a partir de 1996, em sua maioria, não conseguem recompor as perdas decorrentes da inflação e a pressão da opinião pública, na época, era pelo sacrifício de alguns segmentos em prol da vitória contra a inflação. Desta forma, as campanhas a favor de recomposição das perdas decorrentes da inflação eram consideradas impopulares diante da luta que deveria ser executada contra a inflação. A partir disso, a PLR acaba surgindo como uma possibilidade real de recomposição das perdas decorrentes da inflação.

Em outro sentido, a PLR pode ser considerada como uma remuneração variável, um prêmio à produtividade, e o salário passa a ser percebido pelos trabalhadores como decomposto em duas partes: uma variável e uma fixa. A produtividade deixa de ser concebida como um prêmio coletivo para ser concebida como um prêmio individual, não sendo incorporada ao salário.

Os argumentos empresariais sugerem que a produtividade coletiva encobre os custos, por se tratar de uma média, e a produtividade individual ou de um grupo de trabalho é mais apropriada para uma medição mais verdadeira da produtividade da empresa. Passa-se a observar certa naturalização da relação salarial como mais individualizante, ligada a uma competência ou habilidade específica, o que fragmenta muito os trabalhadores.

A PLR não é incorporada ao salário base, isentando-se da carga fiscal, o que é um aspecto extremamente vantajoso para os empresários. Acabou instituindo a normalização da flexibilidade, cujos parâmetros a partir daquele momento são as metas da empresa. Assim, a PLR substitui a política salarial do governo, institui uma remuneração variável percebida como vinculada às diferenças pessoais e cria uma confusão nos sindicatos, que antes pleiteavam uma negociação direta com o empresariado. 
Anteriormente à legislação da PLR, muitas empresas já instituíam mecanismos de remuneração variável, não ligados necessariamente a metas e resultados dos trabalhadores na fábrica, como por exemplo abonos, décimo-quarto salário, acessibilidade ao local de trabalho, riscos à saúde, prêmios, etc.. A PLR institui a norma de flexibilidade: o que antes era uma complementação à renda do trabalhador com base no seu salário fixo, agora tem como base as metas e resultados alcançados pelo trabalhador no âmbito da produção interna da fábrica. Há um deslocamento pequeno, mas extremamente importante na vinculação dos rendimentos dos trabalhadores. $\mathrm{O}$ que antes era percebido como coletivo e fruto de uma política salarial, agora passa a ser considerado como fruto da realização particular de um trabalhador dentro da empresa, com suas diferenças específicas e uma remuneração variável dependendo do esforço despendido nas tarefas realizadas.

A aplicação da PLR pode ser feita de três formas diferentes: a primeira por meio de convenção coletiva da categoria, a segunda, no acordo coletivo da empresa, e por fim, de modo unilateral, com uma proposta fechada da empresa para os trabalhadores. Os dois primeiros casos são firmados nos acordos por meio de uma comissão que conta com a participação sindical. O terceiro, por ser unilateral, não envolve uma negociação e o sindicato permanece de fora. $\mathrm{Na}$ maior parte das convenções coletivas são elaboradas as metas referentes à atuação dos trabalhadores e não os valores a serem recebidos, que ficam dependendo dos resultados dos trabalhadores nestas metas e do desempenho da empresa.

Nesse contexto, ao depender do desempenho da empresa a PLR fica mais restrita a uma empresa em particular, com uma dificuldade de regulamentação mais generalizante, o que permite à empresa conectá-la com os Recursos Humanos, individualizando a produtividade. "Não é justo um grupo que produz mais ganhar o mesmo que outro produzindo menos", reza a cartilha empresarial. Este aspecto interfere na apropriação que os operários têm da produção da empresa, individualizando sua percepção destes processos e gerando uma concorrência em um âmbito que antes não existia.

Os trabalhadores acabam divididos em áreas com remuneração da PLR de forma diversa, onde os salários mais altos acabam recebendo uma PLR mais alta em diversas empresas. Muitas metas são montadas, em alguns casos, umas contra as outras para que não sejam atingidas, como por exemplo, a meta de redução de acidentes e segurança do trabalho versus o aumento de ritmo e intensificação do trabalho. Também, muitas destas metas são discutidas em reuniões periódicas dos trabalhadores e da empresa, o que gera uma cobrança 
mútua entre os operários para atingir a meta, que muitas vezes é impossível de ser atingida. A partir destas reuniões periódicas em muitas empresas o discurso de motivação e de responsabilidade do grupo operário pelas metas tornou-se algo comum, onde a cobrança pelo não-atingimento das metas do trabalhador por outro trabalhador companheiro de equipe se tornou cada vez mais frequente devido à correspondente remuneração menor que o nãoatingimento das metas provocava. A responsabilidade coletiva foi sendo incorporada como responsabilidade pessoal, mediada pela mudança na remuneração. É neste âmbito que surgem diversos conflitos entre os trabalhadores, assim como, diversos acidentes por excesso de trabalho com o intuito de ganhar "mais" (OLIVEIRA et al, 2010).

A substituição de uma regulação pública através da convenção coletiva possibilita, com a PLR, uma descentralização da negociação, que por sua vez é também uma bandeira do novo sindicalismo, onde há autonomia e liberdade de contratação, entre outras reivindicações que os trabalhadores procuravam afirmar perante a tutela autoritária do Estado. Isso acaba chocando com a irrupção da globalização neoliberal e o seu correspondente nas relações do trabalho: a reestruturação produtiva. A organização por local de trabalho é vista como um antídoto ao corporativismo forjado no país pelo projeto nacional-desenvolvimentista. Essa organização asseguraria a representação de fato dos trabalhadores, aproximando o sindicato das bases; o argumento, em alguns casos, é levantado como uma autonomia da ação em relação à instituição do sindicato (democracia no local de trabalho). Porém, como não há uma relação orgânica entre os dirigentes sindicais e os representados por estes, em muitos sindicatos a autonomia esta com a cúpula e não com a base, ocorrendo certa indiferença da base com os "de cima", para a satisfação dos patrões. A própria base se contenta com os benefícios assistencialistas oferecidos pelos sindicatos, como colônia de férias, atividades de lazer, serviço médico, odontológico, descontos em serviços do comércio para os sindicalizados, etc..

A CUT enxergava na livre negociação a medida ideal contra o sistema corporativo. A postura retrógrada das cúpulas sindicais remanescentes do corporativismo logo seria revelada para os trabalhadores da base sindical e a negociação da PLR seria a oportunidade ideal para impor um projeto original de democracia no local de trabalho, como a almejada pelo novo sindicalismo. Há neste sentido uma correspondência entre os ideais do novo sindicalismo (autonomia, democracia, liberdade de negociação e etc.) e os ideais da intelligentsia liberal brasileira (crítica a presença do Estado na vida social, auto-organização 
da sociedade e etc.), embora se trate para o novo sindicalismo de direitos coletivos que não foram assegurados e para os liberais de direitos individuais que prevalecem na sociedade. Para o novo sindicalismo tratava-se de unir o movimento operário e sindical num movimento social amparado na sociedade civil, diferente de seu período como membro do "corpo" do Estado.

Na negociação da PLR, o sindicato tenta influenciar a negociação com a empresa quando se trata de um acordo coletivo. Embora a legislação, que é fruto do peso considerável que o novo sindicalismo tinha na época da redemocratização, determine que deva haver representantes do sindicato em uma comissão eleita pelos trabalhadores, isso não se verifica na prática. (Ver para mais detalhes: KREIN \& SANCHES: 2004).

A ideia principal dos sindicatos, como dito anteriormente, era que a PLR pudesse servir como uma modalidade da organização por local de trabalho, envolvendo os trabalhadores da própria empresa na negociação. Para o novo sindicalismo era necessário ter a participação efetiva de um trabalhador da fábrica, ao invés de somente alocar um dirigente sindical na negociação, tendo como premissa o fato de que o trabalhador que está em contato direto com o processo de trabalho conhece os problemas específicos da empresa e é capaz de exercer, de modo adequado, o papel de representante dos trabalhadores na negociação. “Ao invés de de cima para baixo, de baixo para cima: essa era a máxima organizativa do sindicalismo" (OLIVEIRA, F. et al, 79: 2010).

A participação do sindicato, porém, é necessária, muito embora pareça tutela. Uma vez que eles conhecem algumas armadilhas empregadas pelos patrões na negociação, são necessários também para acompanhar o acordo, monitorá-lo, e devem possuir instrumentos de sanção quando necessário. Os sindicalistas são os mais preparados e organizados para isso. As informações sobre a saúde financeira são difíceis de serem adquiridas pelos trabalhadores, já que são consideradas confidenciais pela empresa, o que coloca um obstáculo para a obtenção das informações necessárias à composição das metas e resultados a serem atingidos pelos trabalhadores, dificultando os parâmetros necessários à negociação. Essas informações podem ser repassadas sem estarem completas ou logicamente inteligíveis e não se pode perder de vista a possibilidade proposital do envio errado das informações pelas empresas, de forma deliberada e com o intuito de obter um maior comprometimento dos trabalhadores, sem, no entanto, desembolsar o valor devido ao cumprimento das metas ou resultados. 
Um dos problemas enfrentados também, é que os membros da comissão da PLR não têm a necessária estabilidade, o que na prática leva a substituição por negociadores sindicais, afastando a comissão da organização por local de trabalho. Os acordos são feitos por composição de interesses entre trabalhadores e capital sem a intervenção do Estado. A organização por local de trabalho, segundo os dirigentes sindicais do novo sindicalismo, poderia fortalecer alguns trabalhadores que fariam o papel do sindicato nas fábricas. $\mathrm{O}$ fato de existirem trabalhadores da base na negociação favoreceria a educação política para as funções de liderança, permitindo-lhes ter uma consciência mais ativa da classe e menos conformada com sua posição social nas relações capitalistas.

Os membros da comissão da PLR ao eventualmente conquistarem ganhos maiores do que os propostos pelas empresas, conforme era almejado pelo novo sindicalismo, acabam adquirindo a legitimidade e confiança dos outros trabalhadores que podem se manifestar contra qualquer tentativa de inviabilização do trabalho desses membros e agir na defesa da presença dos mesmos nestas comissões. De qualquer forma, para os sindicalistas os membros das comissões passam a ter um conhecimento superior do local de trabalho, o que em alguns casos era inacessível para os sindicatos.

Contudo, a incorporação da PLR passa a ser considerada como uma parte do salário e é utilizada nas convenções coletivas como arma dos patrões, pois joga a negociação salarial para baixo, rebaixando o nível do inicio do processo e da negociação, em que as partes são desiguais. Ou seja, a campanha salarial vem em segundo plano, sendo que em algumas empresas considera-se somente a negociação da PLR. Nos setores mais organizados do sindicalismo, a discussão da PLR é desvinculada da campanha salarial, permitindo que o salário fixo seja assegurado em um patamar relevante, para depois buscar conquistas com a remuneração variável derivada da PLR.

Nas empresas pequenas ou medias, os empresários atuam de maneira diferente, procurando pressionar o sindicato patronal a aceitar acordos com menos benefícios para os trabalhadores, uma vez que um acordo que privilegie ou garanta muitas conquistas aos empregados pode gerar a falência de muita dessas empresas, que não teriam possibilidade de disputar o mercado com empresas maiores.

A definição das metas, aspecto fundamental da definição da PLR, funciona como item de ligação direta da PLR com as diversas formas de flexibilidade do trabalho. A PLR acaba condicionando a participação dos trabalhadores a certo comportamento disciplinar e 
racionalizado no processo de trabalho, como ausência de faltas, produtividade individual e etc., sendo considerada mais adequada para acordos coletivos (empresas) como afirmam os empresários, não impedindo-se tratar o setor inteiro como uma pauta historicamente atendida por alguns sindicatos fortes como os petroleiros, bancários e químicos ${ }^{36}$.

A parcela devida dos "resultados" da PLR é fruto do que foi acordado anteriormente pela empresa e os trabalhadores e estes recebem conforme o cumprimento das metas estipuladas, que se referem à produtividade, quantidade de produção, assiduidade, rentabilidade, empenho no trabalho, redução de custos, redução de acidentes de trabalho, comprometimento com a equipe, vendas, índice de qualidade, introdução e incorporação de técnicas de gestão, entre outras. Algumas destas metas são contraditórias entre si, como já dito anteriormente, e são de difícil mensuração objetiva, pois a quantificação de comportamentos que significam empenho e comprometimento pode variar muito.

Com o contrato referente às metas abre-se a brecha para a intensificação do trabalho, diferente do salário fordista que era definido para a categoria de forma coletiva. Seria necessário um poder muito grande dos sindicatos para acompanhar meta por meta e indicar os seus desvios ou falsificações, o que pode acarretar um controle e uma burocracia muito grande para o acompanhamento de algo que foi pensado para garantir rapidez nas relações entre trabalho e capital.

Com relação aos lucros a dificuldade está em medi-los, pois a informação formal é imprescindível. A possibilidade deriva, em alguns casos, do balanço operacional da empresa publicado em jornais ou revistas de economia, entretanto os trabalhadores que atuam no meio sindical têm noção do desempenho da empresa, pois para estes qualquer operário sabe se sua empresa vai bem ou mal pelo contato direto que tem com o processo de trabalho sem a necessidade de planilha ou balanço para comprovar. Em muitos casos a empresa não estipula o pagamento da PLR pelos lucros ou resultados, oferecendo um abono para os empregados, sem identificar um critério para o seu pagamento ou como foi constituído esse abono.

Como a PLR é paga de uma vez ou dividida em parcelas, chegando, em alguns casos, a até oito vezes o salário base, ela atrai a atenção de boa parte dos trabalhadores e dilui o interesse pelas campanhas salariais, no qual os ganhos são mais reduzidos. É necessário, porém, lembrar que a PLR esta atrelada à situação econômica das empresas em um contexto

${ }^{36}$ (Ver para mais detalhes: DIEESE, 2000). 
global, em que predominantemente houve uma expansão, mas também períodos de retração econômica, em que o interesse pela campanha salarial ganha novo fôlego e atrai os trabalhadores.

A PLR acaba sendo um complemento salarial, já que a campanha salarial não repõe as perdas com a inflação, e entra como um abono para cobrir o que faltou. Ela exclui de sua incidência "inativos" (aposentados e afastados por acidentes), estagiários, terceirizados e prestadores de serviços, podendo gerar alguns conflitos.

Os sindicatos tentam estipular regras de linearidade (todos ganham o mesmo) para o recebimento da PLR, sem a diferenciação por cargos na hierarquia da empresa, substituindo a proporcionalidade de remuneração, já que a distribuição diferenciada favorece a individualização nos rendimentos, associada à desempenho ou habilidade, instalando a competitividade entre os trabalhadores e contribuindo para o enfraquecimento da solidariedade entre si. $\mathrm{O}$ tema da produtividade acaba se deslocando de um problema coletivo para um problema da empresa, mais particularizado, sendo muito mais barato para a mesma a negociação via PLR, pois não incidem encargos.

Afirmar uma disputa em torno da PLR parece desprovido de sentido, já que a mesma é uma das medidas mais condizentes com a flexibilização das relações de trabalho, onde a lógica implementada é de valorização dos interesses privados em detrimento dos valores coletivos. A possibilidade de disputa pela PLR é algo prático e não abstrato, abarca certos hábitos, comportamentos, palavras, gestos, costumes, que revelam uma linhagem de classe, uma condição operária cultivada por meio de uma série de costumes derivados do período fordista. Os agentes da classe reconhecem os seus lugares de classe, os locais em que estão familiarizados, que se sentem bem, "à vontade" ou incômodos com o ambiente ao qual não se sente pertencente.

Há uma ofensiva em direção a uma mudança de posicionamento de classe, os trabalhadores são envolvidos nas empresas, se enxergam participando de um projeto comum com a mesma, que usa táticas de persuasão em grupos fechados em um ambiente estranho ao grupo operário, muitas vezes sem representantes sindicais. Com as metas da PLR as empresas estão aplicando os seus projetos de racionalização, que ficam evidentes com os conteúdos das metas, abarcando envolvimento, qualidade da produção, comprometimento, participação nos programas de gestão da empresa, produtividade, etc. ${ }^{37}$.

\footnotetext{
${ }^{37}$ (Ver para mais detalhes: LIMA, 1996; SILVA, 2007; CARDOSO, 2007).
} 
A tendência em substituir o salário fixo pelo variável tem mais duas consequências. Primeiro, ela desorganiza não só o salário de forma direta (salário fixo), mas também de forma indireta, com alguns benefícios atrelados ao salário base previsto na CLT e outros firmados em convenções coletivas, como o vale transporte, o vale refeição, a cesta básica proporcional ao salário base, convênios médicos e etc. além de escalas de classificação como Plano de Cargos e Salários. Algumas das formas de remuneração variável não são esgotadas pela PLR, muitas tinham vigência antes de sua existência; o que ocorre é que a PLR desorganiza estas formas, substituindo-as, incorporando-as, mantendo-as à margem da comissão da PLR, sem a influência sindical. E segundo, a PLR afeta indiretamente a política social do governo, pois é através da massa salarial arrecadada de maneira constante com base no salário fixo que são garantidos a execução de vários programas sociais (segurodesemprego, habitação, educação, seguridade social, etc.) e o principal fundo público, o FAT (Fundo de Amparo do Trabalhador). Com a PLR se estabelece uma luta contra os salários, em torno de uma fixação média da jornada de trabalho, que é uma luta social, não econômica, ou seja, que depende da tolerância com o que a sociedade considera como justo em relação ao mundo do trabalho.

Outra medida fundamental que faz parte da desregulamentação das leis do trabalho é o Banco de Horas. Vinculado à jornada de trabalho, o trabalhador pode ser dispensado do trabalho sem ter sua remuneração afetada e pode ser chamado quando a produção aumenta, numa legislação onde o contrato de trabalho é individual, mas no qual os sindicatos podem intervir com algumas medidas.

Com o banco de horas a remuneração não pode entrar como moeda de troca entre trabalhadores e empresários. Muitos trabalhadores que já estavam acostumados a ganhar um adicional com as horas-extras ficaram insatisfeitos com a medida, porém alguns sindicatos afirmam que zelam pela saúde do trabalhador e por isso têm uma posição favorável ao banco de horas, denunciando as horas-extras como uma negociação da saúde do trabalhador que não deve ser feita pelo mesmo. Havia um excesso de realizações de horas-extras, principalmente nos períodos de crescimento industrial. Segundo os sindicatos favoráveis ao banco de horas, a aplicação do mesmo afeta menos a saúde do trabalhador porque o impede de se exceder na produção. Com essa medida, há um limite para a variação de horas que os trabalhadores podem fazer na empresa, limite esse que pode ser firmado por acordos coletivos. 
O período em que o banco de horas foi aplicado no país foi de forte desemprego e crise na economia brasileira (1996-1999), com diversos acordos levados a cabo para tentar evitar as demissões dos trabalhadores. Entre os itens envolvidos nas negociações estão a jornada de trabalho, os salários e os benefícios. O banco de horas entrou como uma medida a ser aplicada nas empresas para evitar a demissão dos funcionários.

O banco de horas torna o tempo de trabalho mais apropriado para a sazonalidade da produção e a flutuação do mercado, o que implica em considerar as horas não trabalhadas como possíveis de serem debitadas, como para idas ao médico, "pontes" em feriados, ausências referentes a atrasos e etc., o que gera conflitos com relação ao que pode ser considerado como ausências justificadas ou injustificadas. Até pausas antes toleradas, como o tempo para o cafezinho e idas ao banheiro, passam a ser consideradas horas não trabalhadas efetivamente, o que vai gerar um pagamento posterior por parte do trabalhador.

A definição sobre quando o trabalhador poderia compensar ou ausentar-se da empresa devido ao acúmulo ou dívida de horas não pertence ao trabalhador na maior parte dos casos, o que acarreta em uma definição unilateral do empregador quanto à possibilidade de uma ausência do trabalhador quando este achar melhor. Ou seja, a definição do emprego das horas acumuladas de trabalho do funcionário não lhe pertence e, na prática, se ele quiser tirar folga em um dia propício para ele e sua família pode ser impedido pelo patrão, como também a patronal pode estipular um período ruim para o trabalhador compensar as horas adicionais que tenha acumulado, como o meio da semana. O que ocorre é um acordo do tipo liberal, onde há barganhas dos dois lados, sendo, é claro, que o mais prejudicado é o trabalhador.

O banco de horas não assegura a estabilidade do trabalhador, além de rebaixar cada vez mais os salários e não garantir a contratação de mais funcionários, pois a empresa, para aumentar a produção, não precisa contratar mais mão-de-obra, bastando somente sobrecarregar o funcionário já empregado. Em alguns casos, o trabalhador pode chegar a trabalhar cerca de 12 horas por dia, ficando a critério da empresa a limitação da jornada; se precisar, o funcionário é obrigado a trabalhar inclusive aos sábados, domingos e feriados.

A desregulamentação da legislação trabalhista institui a "acumulação flexível" nas relações trabalhistas, modificando parte significativa da sociabilidade do período fordista que envolvia o mundo do trabalho e os operários. A PLR e o Banco de Horas são algumas medidas da reforma na legislação trabalhista que modificam o salário, a jornada de trabalho e o uso da força de trabalho, desmantelando parte do aparato social do Estado. 
Estas medidas modificam a forma de negociação a que os trabalhadores estão acostumados, sua remuneração, seus benefícios, sua forma de luta, a pressão em que estão envolvidos. Fazem emergir novas relações no trabalho, auxiliam na conformação de um consentimento nas fábricas e contribuem para a configuração de uma nova condição operária, com uma sociabilidade interna e distinta às fábricas. Cabe agora compreender como o Sindicato dos Metalúrgicos de São José dos Campos e Região se posiciona e atua diante dessas transformações.

\subsection{O Sindicato dos Metalúrgicos de São José dos Campos e Região}

O Sindicato dos Metalúrgicos de São José dos Campos e Região foi criado em 1956, para representar os trabalhadores metalúrgicos da região do Vale Paraíba, no Estado de São Paulo, um dos pólos industriais e tecnológicos mais importantes do país. As cidades abrangidas pelo sindicato são: São José dos Campos, Caçapava, Jacareí, Santa Branca e Igaratá. O município de São José dos Campos é o maior da região e está entre as dez maiores cidades do país em termos de Produto Interno Bruto (PIB). O sindicato atua em uma região com mais de 40 mil trabalhadores, entre os quais 21 mil são sindicalizados; tem em seu cadastro 980 empresas metalúrgicas, sendo as principais: General Motors do Brasil (Montadora), Embraer (Aeronáutica), LG-Philips, Ericsson, Panasonic (Eletrônicas), Eaton, Bundy, Schereider (Autopeças). (Ver para mais detalhes: MOURA, 2011)

Durante mais de duas décadas o sindicato foi coordenado por dirigentes nomeados pelo Estado, até 1981. Havia, porém uma organização paralela e não formal dos trabalhadores, da qual nem o sindicato oficial e nem o governo faziam parte. Essa organização foi responsável pela realização e comando de greves, mobilizações e resistências dos metalúrgicos nesse período. Em 1981 houve a primeira eleição livre do sindicato, na qual participaram três chapas: a primeira ligada à antiga diretoria corporativa que dominava o sindicato; a segunda ligada a membros que formariam posteriormente a Articulação Sindical (AS), corrente vinculada até hoje ao Partido dos Trabalhadores (PT) e que era bem próxima aos militantes do Sindicato dos Metalúrgicos do ABC; e por fim a terceira, ligada aos trabalhadores que formariam posteriormente a Convergência Socialista (CS), corrente que saiu do Partido dos Trabalhadores em 1992 e deu origem a corrente sindical Movimento por 
uma Tendência Socialista, presente posteriormente no Partido Socialista dos Trabalhadores Unificado (PSTU).

A chapa vitoriosa foi a segunda, ligada à Articulação Sindical, com Ari Russo na presidência, que lá permaneceu durante toda a década de 1980. Essa chapa auxiliou na fundação da Central Única dos Trabalhadores (CUT). Durante esse período houve duas grandes greves, a da Embraer em 1984 e a da General Motors do Brasil em 1985, sendo que nos dois casos houve ocupação nas respectivas fábricas. No final da década, houve a consolidação de uma oposição à direção do sindicato que contava com militantes independentes e outros filiados à Convergência Socialista, que viria a ganhar a direção do sindicato em 1990. Já na eleição de 1993, o sindicato optou por mudar a forma de composição da sua diretoria, mudando do presidencialismo para a forma colegiada (já que esta prescreve uma representação proporcional de todos os grupos/chapas políticas de acordo com o número de votos que tiveram nas eleições). A partir daquele momento, o sindicato passou a ter uma direção que contava com diversas tendências, mas a maioria pertencia à Convergência Socialista, que contava com 21 dos 41 dirigentes sindicais ${ }^{38}$.

A partir do processo de privatização da Embraer, começou uma disputa acirrada pela maioria na composição da diretoria do sindicato entre a Articulação Sindical e o Movimento por uma Tendência Socialista (antiga Convergência Socialista), quando a Embraer passou a ser reduto principal de influência da Articulação Sindical e pólo de oposição ao Movimento por uma Tendência Socialista (MOURA, 2011). Nas eleições de 1995, a Articulação Sindical conquista a maioria da diretoria do sindicato com 21 diretores contra 20 do Movimento por uma Tendência Socialista. Durante esse período, foi marcante a atuação do sindicato como oposição ao governo federal, com um discurso efusivo contra as privatizações e as medidas de desregulamentação das leis do trabalho. Este discurso, porém, dividiu-se entre as duas correntes: uma parte da diretoria (Movimento por uma Tendência Socialista) era contrária a Proposta de Emenda Constitucional de Reforma da Previdência e articulou uma greve geral, enquanto que a outra corrente (Articulação Sindical) quis abrir uma discussão em torno das propostas sobre a reforma.

A diferença entre as duas correntes era clara quanto ao posicionamento do sindicato em relação ao governo. Embora ambas fossem contrárias às medidas apresentadas pelo

38 “Jornal do Metalúrgico", Disponível em: http://www.sindmetalsjc.org.br 
governo, a Articulação Sindical acreditava que o diálogo era possível e desejável para trazer a vitória aos trabalhadores, de modo que a luta deveria ocorrer nos espaços abertos pelo governo para negociação, atuando em caráter propositivo nas instâncias legais. Já o Movimento por uma Tendência Socialista era contrário ao diálogo proposto pela Articulação Sindical, já que enxergava esses espaços como viciados e inviáveis às soluções esperadas pela classe trabalhadora. A possibilidade real para esta corrente era a luta dos trabalhadores e o enfretamento com o governo federal, numa postura combativa que não negociava e não aceitava a redução de direitos dos trabalhadores (FIGUEIREDO, 2007). Em 1997 o sindicato voltou a ter como forma de representação o presidencialismo, devido às grandes divergências entre as tendências e a impossibilidade de juntas gerirem o sindicato.

Durante a década de 1990, o sindicato tinha como proposição a luta contra o neoliberalismo, realizando campanhas e mobilizações contra as reformas Sindical, Previdenciária e Trabalhista, assim como contra a flexibilização das relações de trabalho. Em 2000, Luiz Carlos Prates, o Mancha, venceu as eleições sindicais derrotando a Articulação Sindical e realizando grandes campanhas contra as medidas do governo. O sindicato foi responsável por auxiliar na organização do movimento Fora FHC, Fora FMI (Fundo Monetário Internacional), contra a ALCA (Aliança de Livre Comércio da América) e contra o neoliberalismo.

Na nova eleição que ocorreu em 2003 a Articulação Sindical perdeu ainda mais força no sindicato. Em agosto de 2004, ocorreu um fato de grande relevância para o sindicato: a desfiliação da Central Única dos Trabalhadores (CUT). Como os próprios dirigentes sindicais afirmam, “com a eleição de Lula, a CUT transformou-se numa 'chapa branca', que apoia as reformas que ameaçam os direitos dos trabalhadores, como as reformas Sindical e Trabalhista" 39 .

Desde 2004, o Sindicato dos Metalúrgicos de São José dos Campos e Região atuou na construção de uma nova central sindical, a Conlutas (Coordenação Nacional de Lutas), cujo papel seria coordenar lutas nacionais, e após fusões com outras correntes em 2010, fundou-se uma nova central sindical, a Central Sindical e Popular - Conlutas (CSPConlutas). A Conlutas foi criada como uma alternativa na luta dos trabalhadores diante do

\footnotetext{
${ }^{39}$ Disponível em: http://www.sindmetalsjc.org.br
} 
enfraquecimento da CUT, com o objetivo inicial de agregar os trabalhadores e organizar a luta contra as reformas neoliberais e o modelo econômico aplicado pelo governo Lula.

Atualmente (gestão 2012-2015) o sindicato conta com 41 dirigentes, sendo nove membros da executiva e os outros 32 diretores efetivos. É um sindicato que possui o regime de representação presidencialista, no qual os cargos mais importantes são o de presidente seguido pelo de vice-presidente e a maioria dos dirigentes é filiada ao PSTU. O sindicato se considera como um dos mais combativos do país, de perfil classista e de importância fundamental no cenário nacional na defesa dos direitos dos trabalhadores. $\mathrm{O}$ presidente do sindicato é Antônio Ferreira de Barros, o Macapá (General Motors do Brasil). O sindicato mantém-se na vanguarda da luta contra as medidas da desregulamentação das leis do trabalho e mobiliza os cipeiros (CIPA - Comissão Interna de Prevenção de Acidentes), delegados sindicais e ativistas para de dentro das fábricas organizarem a luta dos trabalhadores e assim se aproximarem da concepção de Organização por Local de Trabalho defendida pelo sindicato (MOURA, 2011).

O Sindicato dos Metalúrgicos de São José dos Campos e Região apresenta uma posição diferente quanto aos diversos temas conjunturais ou estruturais de interesse dos trabalhadores, como as reformas da previdência, sindical, trabalhista e tributária, a PLR, o Banco de Horas, entre outras medidas que denotam distinções significativas entre concepções de sindicato e atuação sindical, que são de fundamental importância para delimitar a posição e atuação política do sindicato em comparação com outros da mesma categoria em regiões diferentes. Para delimitar essa diferença de concepção e atuação dos sindicatos, faz-se necessário realizar uma comparação entre o Sindicato dos Metalúrgicos de São José dos Campos e Região, o Sindicato dos Metalúrgicos de São Paulo e o Sindicato dos Metalúrgicos de São Bernardo do Campo e Diadema (que nessa dissertação será denominado como Sindicato dos Metalúrgicos do $\mathrm{ABC}$ ), já que estes dois últimos sindicatos possuem representação sobre a mesma categoria/atividade profissional que o primeiro, mas com uma representação sindical (grupo político) e filiação a uma central sindical diferente. A comparação contará com o auxílio e contribuição proveniente do trabalho teórico de Marcela Medeiros Moura (2011) e sua análise dos três sindicatos.

A filiação do Sindicato dos Metalúrgicos de São José dos Campos e Região à CSPConlutas e sua atuação coerente com os princípios que norteiam essa organização possuem relevância na postura adotada pelo mesmo em relação à Reforma da Previdência. A proposta 
do Governo Lula para esta reforma e a relutância da CUT em se posicionar contrariamente (posicionaram-se a favor do diálogo) foram os principais motivos do crescimento das divergências entre o sindicato e a central sindical, culminando no seu posterior desligamento da CUT. A Reforma da Previdência estimulava a expansão da previdência privada. Os pontos mais polêmicos eram a taxação dos inativos, o fim da integralidade no pagamento da aposentaria dos servidores públicos, o aumento da idade mínima para a aposentadoria e o estabelecimento de um valor como teto para a aposentadoria dos servidores.

Para o sindicato as reivindicações deveriam ser: pela volta da aposentadoria especial para trabalho insalubre; por uma aposentadoria com salário integral para todos, por tempo de serviço; pela não utilização do dinheiro da previdência para o pagamento das dívidas externa e interna; pela cobrança da dívida do INSS (Instituto Nacional do Seguro Social) das empresas e prefeituras; pela punição rigorosa para os sonegadores e ladrões da previdência; e por uma previdência social solidária para que todos os trabalhadores tenham acesso à Saúde Pública, Assistência Social e Previdência. Para o sindicato, a Reforma da Previdência tinha o interesse de atender aos objetivos do Banco Mundial e do FMI de privatizar a previdência, repassando aos bancos a possibilidade do trabalhador ter acesso a uma aposentadoria maior. A atuação do sindicato não ficou restrita somente ao discurso, tendo havido uma marcha contra a Reforma da Previdência que agregou 50 mil pessoas e teve a participação de membros do sindicato (MOURA, 2011).

O Sindicato dos Metalúrgicos de São Paulo é filiado à Força Sindical, central sindical que praticava o "sindicalismo de resultados", em que o fim não é a organização política e autônoma dos trabalhadores, mas ao contrário, conseguir alianças entre Capital e Trabalho, já que se acreditava que essa forma possibilitava a conquista de maneira mais rápida de resultados e benefícios aos trabalhadores. Esse sindicato posicionou-se a favor da Reforma da Previdência, afirmando que havia um problema grave com a previdência no país, criticando os "privilégios" do setor público (aposentadoria integral) e propondo a extinção do regime específico do funcionalismo público como forma de estimular a complementação via previdência privada, o que confluía com os interesses e políticas neoliberais. Somente em algumas medidas eles se colocaram como contrários, como na alteração na idade mínima para a aquisição da aposentadoria e a recuperação das perdas dos aposentados em relação ao salário mínimo. 
O Sindicato dos Metalúrgicos do $\mathrm{ABC}$ é filiado à CUT, é um dos maiores sindicatos metalúrgicos do país e possui uma longa trajetória política de luta a favor dos trabalhadores, principalmente na década de 1970 e 1980, contando como figura renomada desta trajetória o presidente Lula. A imagem do sindicato possui uma associação grande com Lula e a gestão do sindicato (Articulação Sindical) é acusada por seus opositores de atuar em prol do governo e deixar as demandas históricas dos trabalhadores em segundo plano. A partir disto, cabe analisar o posicionamento que o sindicato adotou frente às modificações no mundo do trabalho e as propostas de reformas do governo.

Esse sindicato tinha uma posição favorável à Reforma da Previdência, mas também apresentava, em alguns momentos, uma posição ambígua em relação à mesma. Ele afirmava que a reforma não prejudicaria o trabalhador, que, pelo contrário, lhe era favorável. A ambiguidade aparece no fato de o sindicato falar em seu nome a favor da reforma, dos benefícios provenientes dela para os membros do sindicato e utilizar a CUT para indicar as desvantagens para os servidores públicos. O sindicato coloca-se a favor daquilo que a reforma traz de bom para a sua categoria, ao mesmo tempo, que se coloca a favor das críticas da CUT. Uma afirmação vaga e questionável diante da necessidade de um posicionamento mais claro, a favor ou contra a Reforma da Previdência.

As reformas Sindical e Trabalhista, postulam a modificação da legislação trabalhista e sindical. Em relação à Reforma Trabalhista, esta tinha o intuito de desregular as leis do trabalho, reduzindo os direitos dos trabalhadores. A Reforma Sindical postulava uma alteração da estrutura sindical em que os temas mais polêmicos eram o fim da unicidade sindical, a definição conceitual de categoria, o poder normativo da justiça do trabalho, os tributos compulsórios para o financiamento dos sindicatos, a extinção escalonada do imposto sindical no prazo de quatro anos e a atribuição às Centrais Sindicais de negociarem pelos trabalhadores e/ou indicarem o sindicato representativo pela negociação.

O Sindicato dos Metalúrgicos de São José dos Campos e Região posicionou-se contrário à Reforma Sindical, pois considerava que esta acabaria com o poder de decisão das assembleias dos trabalhadores, da base sindical, transferindo-os para as cúpulas sindicais, o que abriria brecha para a retirada de direitos dos trabalhadores. Essas mudanças levariam a uma centralização do poder nas mãos da direção sindical afinada com o governo, que tinha o interesse em flexibilizar os direitos trabalhistas. A reforma transfere o controle da estrutura sindical, antes nas mãos do Estado, para a Central Sindical, o que na proposição do sindicato 
esta distante das reivindicações históricas do novo sindicalismo como a liberdade e autonomia sindical do movimento.

Alguns dos direitos sindicais tinham propostas de mudança e para o sindicato era necessário resguardar a democracia presente na base sindical. A negociação coletiva, o controle da estrutura sindical, o financiamento sindical e o exercício do direito de greve são pontos previstos na reforma sindical que levariam mais poder a cúpula sindical em detrimento da base. Com isso, o Sindicato dos Metalúrgicos de São José dos Campos realizou uma ampla discussão sobre a Reforma Sindical, assim como, uma ampla mobilização de sua base com manifestações contrárias à esta reforma. O sindicato criticou abertamente a Força Sindical e a CUT, pois afirmava que com a aprovação da Reforma Sindical estas centrais veriam a sua arrecadação crescer e teriam maior poder sobre a base. Em relação à Reforma Trabalhista, o sindicato posicionou-se contrariamente, pois tais mudanças teriam um caráter de flexibilização das leis trabalhistas e serviriam como parte do processo de expansão de políticas neoliberais no país.

Em 1998, o Sindicato dos Metalúrgicos de São José dos Campos e Região rompeu com a Federação dos Sindicatos Metalúrgicos ligados à CUT. Os principais motivos do rompimento foram o fato de se recusar a flexibilizar a jornada de trabalho e a recusa da aplicação do banco de horas nas fábricas representadas. A Federação dos Sindicatos Metalúrgicos (FEM-CUT/SP) representa atualmente 12 sindicatos metalúrgicos filiados em todo o Estado e é a interlocutora dos trabalhadores nas negociações da campanha salarial com as bancadas patronais. Outros dois sindicatos que romperam com a FEM-CUT/SP foram o Sindicato dos Metalúrgicos de Campinas e o Sindicato dos Metalúrgicos de Limeira, que recusaram junto com o Sindicato dos Metalúrgicos de São José dos Campos a convenção coletiva firmada pela FEM-CUT/SP, que aceitava a instituição do banco de horas. Esses sindicatos faziam oposição às convenções coletivas firmadas pela Federação e conseguiram assinar uma convenção diferenciada, com a negociação de reajustes de salários e mantendo os direitos trabalhistas. O posicionamento em relação à Reforma Trabalhista pelo Sindicato dos Metalúrgicos de São José dos Campos e Região será mais detalhado nos próximos capítulos.

O Sindicato dos Metalúrgicos de São Paulo posicionou-se favoravelmente às medidas da Reforma Sindical, pois acreditava que esta poderia aprofundar a democracia sindical, fazer avançar a qualificação do trabalhador, acabar com a competência da justiça do trabalho para dissídio de greve, definir a representatividade sindical, melhorar o dirigente 
sindical, legalizar as centrais sindicais, garantir juridicamente e fortalecer a representação pelo sindicato da categoria nas negociações coletivas com os empregadores, acabar com o imposto sindical e substituí-lo pela contribuição negocial, fazer valer os direitos dos trabalhadores e fazer valer a estabilidade do dirigente sindical e do Cipeiro.

Em relação à Reforma Trabalhista, o discurso do sindicato se apoia na ideia de modernização, a mesma doutrina de modernização que vigorou na década de 1990 nas políticas neoliberais e que os empresários defendiam como necessária à competição do país no mercado internacional. Sem a reforma o país poderia aumentar o índice de desemprego de forma acelerada. O sindicato apoia a flexibilização da Consolidação das Leis Trabalhistas (CLT), que deve ser atualizada, mas sem diminuir direitos. Sendo a CLT uma garantia dos direitos dos trabalhadores e o sindicato não possuindo uma formulação clara do que é essa modernização ou flexibilização da CLT, na prática pode significar a perda de direitos dos trabalhadores.

Do mesmo modo, o sindicato defende o fim da "terceirização irregular", não postulando o que significa essa terceirização. Outros temas discutidos na reforma também apresentam declarações ambíguas do sindicato, como estabilidade (só aparece em suas campanhas estabilidade de delegados sindicais, acidentados ou enfermos decorrentes de doenças de trabalho, isto é, as que já estão previstas em lei), PLR (consideram-se os precursores da medida e colocam-na como algo extremamente positivo para o trabalhador) e banco de horas (MOURA, 2011).

Para o Sindicato dos Metalúrgicos do $\mathrm{ABC}$ a Reforma Sindical proposta pelo governo Lula trazia em seu conteúdo a ideia de liberdade sindical e de fortalecimento dos sindicatos e, como tal, deveria ser aprovada para o benefício dos trabalhadores. Os pontos principais desta para o sindicato são o reconhecimento das centrais sindicais; o fim do imposto sindical, posteriormente substituído pela contribuição negocial; a prevalência da liberdade sindical sobre a unicidade, com critérios de representatividade dos sindicatos; a regulamentação das ações coletivas pelos sindicatos; uma mudança do conceito categoria levando em conta a atividade econômica principal e não mais a profissão; uma nova dinâmica no processo de negociação coletiva; o fim do poder normativo da Justiça do Trabalho e a organização no local de trabalho. O sindicato se negou a estabelecer uma discussão sobre a flexibilização de direitos trabalhistas afirmando que naquele momento o mais importante era a 
discussão referente à reforma sindical, o fortalecimento da entidade sindical nas negociações para posteriormente discutir a reforma trabalhista. Como afirma Moura:

\begin{abstract}
"O sindicato optou por afastar o debate sobre um tema de total interesse dos trabalhadores, ou seja, os direitos trabalhistas. Essa postura inicial do sindicato indica uma estratégia política de apoio ao governo no primeiro bloco de reformas, concordando em abrir espaço para uma reforma sindical que favorece somente os grandes sindicatos e as centrais sindicais em detrimento da autonomia da base. Conquistada essa primeira reforma, o teor da reforma trabalhista, se aquela tivesse sido aprovada, teria sido assumida com o discurso da prevalência do negociado sobre o legislado, retirando direitos e garantias já conquistadas e positivadas no ordenamento jurídico como direitos mínimos a serem respeitados” (MOURA: 80, 2011).
\end{abstract}

Para o sindicato as críticas à Reforma Sindical eram intrigas da oposição, o que acabou impedindo uma ampla discussão sobre os pontos polêmicos que interessavam aos trabalhadores. O objetivo era que as reformas fossem aprovadas no primeiro mandato de Lula como forma de neutralizar as "forças de direita" do Brasil. Em relação à Reforma Trabalhista posicionavam-se a favor de uma regularização da terceirização, da mesma forma que a CUT, o que significa que exigiam que se regulamentasse algo ilícito e assim acabavam afirmando que esse ilícito não deve ser combatido, mas sim incorporado ao ordenamento jurídico. Assim, a postura de aceitar que haja terceirização é ao mesmo tempo dificultar a sua erradicação. O sindicato se coloca como favorável ao Programa de Desligamento Voluntário (PDV) entendendo que o mesmo evitaria as demissões, demonstra-se favorável a PLR, sem apresentar críticas às suas medidas, depositando confiança no acordo e na força do sindicato para conquistas superiores dos trabalhadores, como no caso da PLR com um bom índice de remuneração e sem metas muito altas.

Além dessas reformas é possível verificar a diferença no posicionamento político dos sindicatos e sua atuação coerente em relação a esta posição a partir da análise das campanhas salariais e dos acordos coletivos. Os principais temas abordados nos acordos coletivos são: reajustes salariais, jornada de trabalho, com suas durações previstas e o banco de horas; o contrato de trabalho, sua possibilidade de flexibilização e terceirização (ou tipos de contratos precários); e a vinculação da PLR. 
De acordo com o estudo de Marcela Medeiros Moura ${ }^{40}$, as campanhas salariais obtiveram um reajuste salarial de $8 \%$ para todos os sindicatos nos anos de 2000 a 2002, exceto o reajuste obtido por alguns grupos do Sindicato dos Metalúrgicos de São José dos Campos e Região, que receberam um percentual superior aos outros dois sindicatos. Entre o período de 2005 a 2007, os metalúrgicos de São José dos Campos alcançam um reajuste inferior ao dos metalúrgicos de São Paulo e do $\mathrm{ABC}$, que apresentam índices semelhantes. Já no período de 2008 a 2010, há um reajuste maior de alguns grupos representados pelo Sindicato dos Metalúrgicos de São José dos Campos em comparação com o reajuste obtido pelos outros dois sindicatos.

É possível encontrar uma relação profunda entre a política governamental, os sindicatos e as centrais sindicais que os representam e o índice alcançado nestes períodos, já que os metalúrgicos de São Paulo e do ABC apresentam índices semelhantes, com índices de crescimento principalmente depois do apoio dos sindicatos ao governo Lula. Porém o Sindicato dos Metalúrgicos de São José dos Campos e Região apresenta um declínio nos percentuais de reajustes salariais no ano de 2005, devido ao fato de estarem fragilizados politicamente, com o rompimento com o governo e a CUT e iniciado a fundação da CSPConlutas, instrumento importante de crítica sindical ao governo, porém ainda minoritária.

Em relação aos acordos coletivos não é possível apontar diferenças substanciais, como foi o caso de temas conjunturais como as reformas da Previdência, Sindical e Trabalhista. A partir disto, poderia se apresentar como contradição entre a posição defendida pelo Sindicato dos Metalúrgicos de São José dos Campos e Região e os resultados dos acordos coletivos firmados nas empresas representadas pelo mesmo. Neste caso, há diversos fatores que podem explicar essa contradição, como a conjuntura política e econômica, que influencia a estratégia do sindicato; a força de pressão que o sindicato pode exercer em contraposição a força apresentada pelos empresários; a organização do sindicato e a relação com os interesses e pautas da base, que podem apresentar resoluções mais imediatas que os interesses do sindicato.

Segundo o estudo realizado por Moura, "Há sim uma co-relação de influência entre sindicatos e central e esta relação é perfeitamente coerente com a historia política de cada um desses sindicatos e dessas centrais" (MOURA: 138, 2011). Neste sentido, é possível afirmar

\footnotetext{
${ }^{40}$ Para mais detalhes: (MOURA, 2011).
} 
que estes sindicatos representam possibilidades e aspirações políticas diversas no cenário político brasileiro e assim a comparação entre as reivindicações e as atuações dos sindicatos oferece instrumentos fundamentais para a dimensão política que estes representam.

O Sindicato dos Metalúrgicos de São José dos Campos e Região, a partir da comparação com o Sindicato dos Metalúrgicos de São Paulo e com o Sindicato dos Metalúrgicos do $\mathrm{ABC}$, apresenta uma relação de questionamento e vigilância das medidas apresentadas pelo governo Lula, em que faz duras críticas às políticas neoliberais adotadas pelo governo, assim como foram também adotadas pelo governo anterior (Fernando Henrique Cardoso). O sindicato denuncia a submissão da CUT ao governo e seu distanciamento na luta pelos direitos e interesses dos trabalhadores, em favor de pequenas adesões à flexibilização dos direitos trabalhistas em proveito da manutenção do governo Lula, descrito como de esquerda pelos mesmos.

A posição do Sindicato dos Metalúrgicos de São José dos Campos e Região, quando comparada à dos outros sindicatos, é uma posição que pode ser designada como combativa, classista e politicamente de esquerda, já que há uma luta constante em defesa dos direitos dos trabalhadores, com uma atuação coerente com estes preceitos e sem se submeter aos interesses do governo. Neste sentido, o Sindicato dos Metalúrgicos de São José dos Campos e Região apresenta uma resistência efetiva à aplicação de medidas neoliberais, com uma direção política atuante em defesa dos direitos dos trabalhadores, que possui o respaldo e adesão da maioria dos trabalhadores da categoria, já que as gestões sindicais possuem uma coerência e continuidade em relação ao grupo político que está no poder do sindicato.

A partir desse histórico sobre o sindicato e a resistência e luta que o mesmo exerce em favor dos trabalhadores, cabe verificar no próximo capítulo quais são as estratégias que as empresas procuram colocar em voga para conquistar o consentimento interno às fábricas, junto aos trabalhadores, e qual é o papel do sindicato em relação a essas ofensivas patronais. 


\section{Capítulo III - Consentimento e resistência no Sindicato dos Metalúrgicos de São José dos Campos e Região}

\subsection{Desregulamentação das leis trabalhistas e o consentimento operário}

As medidas da desregulamentação das leis trabalhistas e a desestruturação do mercado de trabalho modificaram a condição operária, pois foram uma das bases para a queda da relativa estabilidade que os trabalhadores formais tinham no Brasil. Possui uma relação direta com a construção e conformação do consentimento nas fábricas, uma vez que permitiu a fragmentação da classe trabalhadora, a individualização das relações de trabalho e o crescimento da concorrência entre os próprios trabalhadores, favorecendo a perspectiva de que não há mais classes sociais na produção e sim indivíduos, que produzem de forma diferenciada, com suas particularidades específicas. A quebra da relativa estabilidade que existia beneficiou a flexibilidade que os empresários almejavam implementar e auxiliou na persuasão para os trabalhadores aderirem a essa "nova postura".

O discurso do governo na década de 1990 era de que a livre negociação sem a interferência do Estado seria adequada às reivindicações de liberdade sindical e à negociação direta do movimento operário mais progressista do país, o novo sindicalismo. Este discurso encobria uma possibilidade real na conjuntura brasileira de os empresários aplicarem medidas que modificassem as relações produtivas, já que uma negociação direta acabou privilegiando os capitalistas em detrimento da maioria dos trabalhadores, principalmente aqueles do setor menos organizado, que se concentra nas pequenas e médias empresas. A livre negociação proposta não era realmente "livre", pois estabelecia condições claras quanto aos patamares tolerados para a realização de acordos salariais. Ela, como outras medidas da desregulamentação das leis do trabalho, reflete a instabilidade do novo cenário político e econômico do país, em que a flexibilidade, a instabilidade e a inconstância começam a vigorar nas relações de trabalho, auxiliando na conformação de uma nova configuração da condição operária.

A PLR é uma das medidas da desregulamentação das leis do trabalho que tornou flexível a mão de obra e transformou a forma tradicional de negociação que os sindicatos realizavam com os empresários, instaurando uma instabilidade na remuneração dos trabalhadores em comparação com a já precária estabilidade que estes possuíam no país. Os 
sindicatos, quando realizaram a negociação da PLR como um experimento de livre negociação e organização por local de trabalho para os trabalhadores da base, acabaram por aceitar participar do jogo, como o próprio dirigente do Sindicato de São José dos Campos e Região afirma. De acordo com os padrões éticos de pesquisa optou-se por não divulgar o nome real dos entrevistados, visando preservar suas identidades ${ }^{41}$.

"À medida que nós trabalhadores aceitamos uma meta de trabalho, nós estamos aceitando que aumentem a doença ocupacional, o índice de acidentes, o número de trabalhadores enfermos. É isso que significa meta, numa empresa. Então nós damos toda a explicação, mas o pano de fundo nas empresas, pra eles, é a meta. Então os trabalhadores colocaram a meta, na qual eles têm o controle. Nós começamos a estudar a produção possível de tirar dos trabalhadores. E nessa produção nós colocamos os valores. Valores por quantidade de motor, de carro. Fazemos um apanhado do valor de cada item, nas metas, para que nós possamos tirar uma participação de resultados boa e que não force os trabalhadores no futuro. Mas mesmo assim, o plano de essência entra. Porque na verdade, quando eu começo a discutir a PLR eu já entrei no jogo". (Roberto, entrevista de pesquisa, setembro de 2011).

A própria representação da gestão do sindicato reconhece que, ao aceitarem negociar a PLR com os empresários, os trabalhadores estão acatando as mudanças e colaborando com as empresas, já que não se pode jogar um jogo e ao mesmo tempo questionar as regras. A atividade de jogar um jogo gera consentimento com relação às suas regras. $\mathrm{O}$ sistema de recompensa na remuneração para os trabalhadores é baseado no esforço individual e não coletivo na maior parte das empresas e com isso os trabalhadores individuais encaram um ao outro, em conflito ou competição.

Há um rompimento com a condição operária do período fordista, que garantia certa estabilidade aos trabalhadores. Atualmente, estes trabalhadores não possuem essa estabilidade e nem uma definição clara da clássica divisão entre Capital e Trabalho, a começar pelo próprio processo produtivo que mudou de configuração, o que segundo os dirigentes do sindicato foi calculadamente planejado:

\footnotetext{
${ }^{41}$ A pesquisa colheu um número relevante de dados e optou por sintetizar as entrevistas em alguns dirigentes sindicais que não atuavam diretamente na produção e, em alguns casos, eram responsáveis por regiões distintas em que o sindicato atuava, como no caso de Roberto (General Motors do Brasil), Domingos (Chácaras Reunidas), Vitor e Adriano (Embraer), além de Geraldo que não estava vinculado a uma região especifica. Embora a dissertação apresente aparentemente poucas entrevistas, estas contemplam os objetivos delimitados pela pesquisa.
} 
"E mais do que tudo ideologicamente construída. Há uma mudança profunda nas fábricas hoje. Não tem mais a chefia que existia, os chefes hoje não são chefes. Eles são mantenedores, são lideres, são conselheiros, e o trabalhador ele num vê o cara como ele via antigamente, como eu vi, quando entrei lá no velho $\mathrm{ABC}$, que o cara era de capacete branco, de capacete amarelo, a massa de capacete azul. Antes, pelo capacete você reconhecia o chefe e o grau dele. Cada capacete era uma divisa. Cada uniforme um chefe, uma divisa. Hoje não existe mais. Hoje, o cara está com o seu uniforme, está do seu lado. Vai na sua casa fazer churrasco com você, conhecer sua família, e num é ele que oferece, é você que tem que convidar. Porque na prática soma pontos". (Domingos, entrevista de pesquisa, outubro de 2011).

A distinção entre Capital e Trabalho favorecia o movimento operário no período anterior à nova configuração da condição operária, pois permitia um sentimento de pertencimento à classe operária. Em diversos casos, contava muito mais a solidariedade de classe e a cooperação entre seus membros do que a competição entre o grupo operário, como ocorre atualmente em muitas empresas, particularmente fomentado por estas com a intenção de obter uma maior produtividade dos trabalhadores.

A PLR torna-se uma negociação diferenciada e não mais coletiva, que ocorre no âmbito da empresa e transforma-se em uma remuneração variável para o trabalhador, de modo que alguns acabam deixando a negociação salarial coletiva em segundo plano. Ela se aproxima do jogo de "making out" definido por Burawoy, no qual os trabalhadores se empenham para atingir as metas colocadas pelas empresas ou negociadas junto com os trabalhadores.

Ao se empenharem e participarem dessa transformação na fábrica, os trabalhadores acabam "entrando no jogo" e assim é possível, para os empresários, reduzirem os conflitos advindos de vários prejuízos que os trabalhadores sofreram, como por exemplo a perda real do seu poder aquisitivo nos últimos anos, com base no salário fixo. As regras para o cumprimento da PLR são avaliadas em termos dos resultados definidos na disputa, em atingir ou não atingir as metas. Os resultados vão além do lucro para os capitalistas e têm como consequência a reprodução e obscurecimento das relações capitalistas no processo de produção.

Esta medida enfraquece a luta dos trabalhadores, pois é aplicada na maior parte das fábricas para uma mensuração individual do funcionário, na qual este recebe valores distintos dependendo de seu "comprometimento" e "rendimento" nas empresas, ao contrário do período anterior em que havia certa simetria nos valores dos assalariados da mesma categoria ou atuação profissional. Esta medida passa a ser compreendida como um prêmio à 
produtividade e o salário passa a ser percebido pelos trabalhadores como decomposto em duas partes: uma variável e uma fixa. A produtividade deixa de ser concebida como um prêmio coletivo para ser arquitetada como um prêmio individual, não sendo incorporada ao salário.

Esta mudança altera a perspectiva e o foco de luta de muitos trabalhadores, de uma luta em prol da classe e dos "companheiros" para uma luta em beneficio da empresa e contra os "companheiros" de trabalho. O trabalhador acredita participar de um projeto comum com a empresa, como um "colaborador" nos interesses da mesma, no qual o seu rendimento e sua produtividade refletem o rendimento e a produtividade da empresa, mesmo que isso represente denunciar, prejudicar ou caluniar outros trabalhadores da mesma empresa.

Os "valores" e a "moral" defendidos agora são outros e estão ligados à uma competência ou habilidade específica, que individualiza e fragmenta muito os trabalhadores. Há uma "nova ideologia" que contempla um novo "modo de vida", que tem como principio norteador algumas características do neoliberalismo. Os "valores" são relacionados à competição, flexibilidade, rapidez e outros, figurando muito mais nas cartilhas empresariais do que no cotidiano operário.

A remuneração da PLR conquistada pelos trabalhadores é uma medida que favoreceu a persuasão e o consentimento dos operários. Adotada nas fábricas do país, tem como objetivo envolver e comprometer os operários em um novo modo de organização do trabalho e em um novo "modo de vida", em proveito dos capitalistas. Quando os capitalistas não visualizarem mais os benefícios da adoção dessa medida, eles não pensarão duas vezes em retirá-las e adotarem outras que possam ter a mesma efetividade, utilizando até, em alguns casos, aparelhos coercitivos de modo mais constante.

A responsabilidade por alcançar as metas foi colocada para os trabalhadores, que se tornaram "responsáveis" pelo processo produtivo da empresa. Se não houver, por exemplo, a conclusão de uma meta a culpa é do grupo ou de um trabalhador em particular, o que gera e ocasiona muitas cobranças internas, principalmente por parte de outros trabalhadores que fazem o papel de chefia, ainda que sem o pedido ou obrigação pelo chefe. A responsabilidade do trabalhador passa a ser semelhante à de um chefe, porém sem o rendimento ou remuneração que um chefe ou patrão recebe. "O trabalhador é gerente de si mesmo" é o lema das empresas que buscam apresentá-los como "parceiros", "colaboradores", "operadores" de algo partilhado por todos, onde seu "sucesso" representa o "sucesso" de todos. Assim, a 
jornada de trabalho não necessita ser respeitada em prol desse sucesso almejado, tendo o “colaborador” que aplicar o máximo de esforço e dedicação em suas funções.

A PLR condiciona os trabalhadores a certo comportamento disciplinar e racionalizado no processo de trabalho. Com ela é possível exercer maior controle sobre os trabalhadores, para além daqueles anteriormente utilizados como multas por falta, descontos no salário, advertências e etc.. Neste novo momento, o trabalhador depende, na maior parte dos casos, de uma colaboração com a empresa (envolve, por exemplo, não ter uma atuação sindical combativa), e de uma performance quase perfeita (as metas são muito difíceis de serem atingidas) para conseguir uma remuneração semelhante à que tinha no início da aplicação da PLR, devido sua perda no poder aquisitivo durante as ultimas décadas.

O Banco de Horas, como já definido anteriormente, implica em considerar as horas não trabalhadas como possíveis de serem debitadas como, por exemplo, para idas ao médico, em "pontes" em feriados, em ausências referentes a atrasos e etc.; até o tempo para o cafezinho e idas ao banheiro passam a serem consideradas horas não trabalhadas efetivamente, gerando pagamento posterior por parte do trabalhador. A resolução de conflitos quanto ao que pode ser considerado como ausência justificada ou injustificada depende muito da força do sindicato na negociação com a patronal, ou da "cooperação" dos trabalhadores com a empresa. O Banco de Horas faz parte das estratégias empresariais para enfrentar a sazonalidade e flutuação do mercado, também colocando o trabalhador à mercê deste mercado. Sendo vinculado às flutuações do mercado, o trabalhador é considerado variável, vulnerável e dispensável, não mais possuindo as proteções que antes lhe eram garantidas pelo Estado e cooperando cada vez mais com a empresa para manter-se no emprego:

"Cada vez mais o trabalhador fica à mercê do mercado. E a exploração do trabalho no mercado vem aumentando ostensivamente. O cara entra mais cedo, não pra ganhar hora extra, mas pra atingir a meta de venda". (Roberto, entrevista de pesquisa, setembro de 2011).

As metas, entre outras exigências, prescrevem em muitas empresas o "empenho no trabalho", o "comprometimento com a equipe", coisas que não têm mensuração visível ou razoável para a maior parte dos trabalhadores. Acabam condicionando e determinando, em diversos casos, a não participação do trabalhador em nenhum movimento contrário ou contestatório à empresa. $\mathrm{O}$ trabalhador fica refém da empresa, do chefe, do grupo ou equipe de trabalho, sofrendo uma espécie de "lavagem cerebral" da empresa, como afirmam os 
dirigentes do Sindicato dos Metalúrgicos de São José dos Campos em relação ao Projeto Boa Ideia que existia na Embraer:

\begin{abstract}
"Essas metas da PLR que é também os do Programa de Metas Setorial (PMS), antigamente até tinha o projeto boa ideia, você tinha uma ideia e ganhava um 'premiozinho', agora eles atrelaram ao PMS, se você num atingir um tanto de metas no PMS, você também perde no PLR. O cara chega pra você e fala 'Pô, você tem aí cinco anos de empresa, e não deu nenhuma ideia, tem que dar aí pelo menos uma, cara.' E força ele a dar ideia. Aí ele dá uma ideia, aí que traz cinco mil, 20 mil, 500 mil de lucro pra empresa, e a empresa dá um relógio, um forno elétrico, dá essas coisas pro cara. (...) Ah, praticamente 90 a 95\% (incorporou o projeto). O cara dá ideia. Eles faziam uma premiação que as melhores ideias, o cara ganhava uma viagem pra São Paulo, ir no teatro com a família e tal. Aí o cara fica disputando essas coisas bobas. E coloca a família no meio pra ela ver e incentivar o cara a não perder esse emprego. "A empresa é muito boa e tal.", (Vitor e Adriano, entrevista de pesquisa, novembro de 2011).
\end{abstract}

O comprometimento com a produção ou o "jogo" já está incorporado pelos trabalhadores, já virou parte do seu cotidiano interno na empresa. Porém para o sindicato isso está ligado ao medo das demissões que os trabalhadores sofreriam caso não fossem considerados colaboradores que "vestem a camisa":

"Todo dia eu tento entender isso, porque o trabalhador se dedica tanto, nós falamos pra ele, que aquela ferramenta, está demitindo. Está reduzindo custos, e reduzir custos é mandar o trabalhador embora. Todo dia a gente fala isso pra eles. E eles chegam lá e se empenham, mas porque isso já se tornou parte da rotina. Se eles não se empenharem, serão considerados maus funcionários, e aí, infelizmente o que acontece? O trabalhador não deu sugestão, não está empenhado naquilo. Mas aí, o novo modelo operacional passou ali, e como ele passou e enxugou o setor, sobrou uma ou duas pessoas, chega pra eles e manda eles embora, 'eles não estavam vestindo a camisa', mas não é por causa disso, é porque estava sobrando de fato na sessão. E aí o cara fica com medo da demissão, aquela rotina passa a ser constante." (Vitor e Adriano, entrevista de pesquisa, novembro de 2011).

Os bônus, prêmios e ganhos adicionais que o trabalhador recebe são referentes à sua participação vitoriosa no "jogo" estabelecido pela empresa, sinalizando o seu "comprometimento" e "empenho" com a mesma, embora para o sindicato estes se tornem descartáveis quando a empresa não enxerga mais importância no seu trabalho:

"Você dá as sugestões, e num tem importância nenhuma pra empresa enquanto pessoa. E você é obrigado a dar as sugestões pelo PMS. Por que se você não dá sugestão você é um funcionário que já não está mais preocupado 
com a empresa, você já não é mais necessário pra empresa.” (Vitor e Adriano, entrevista de pesquisa, novembro de 2011).

Algumas empresas possuem até cartilhas de valores que são distribuídas para os trabalhadores com a intenção de obter o comprometimento e dedicação dos funcionários em relação às suas tarefas na empresa, processo de moralização semelhante ao que Ford levava a cabo com os operários de sua fábrica no período taylorista/fordista. Na Embraer, essa cartilha de valores, como não poderia ser diferente, enfatiza os empresários ou "acionistas":

"Ali é o seguinte, uma das primeiras coisas é o acionista. "existimos para servir nossos clientes", nós temos que trabalhar para os acionistas. Eu num tenho todas assim de cabeça, mas é cada uma que chega a dar nojo." (Vitor e Adriano, entrevista de pesquisa, novembro de 2011).

A Embraer, segundo os dirigentes do sindicato, utilizava palestras, cursos e encontros com a intenção de persuadir os operários da importância de seus "valores" e da inevitabilidade da atitude da empresa em relação a alguns trabalhadores "não produtivos", afirmando que não há saída no novo momento econômico, apresentando assim seus valores "neoliberais" da mesma maneira que Gramsci descreve a construção da hegemonia imersa em valores supostamente universais:

"Só que eles colocaram uma equipe que veio dar o curso, o cara veio com uma calça camuflada do exército. Ele tinha um bigodão e parecia um general. O cara chamava Geraldo, e ele dava a palestra, mostrava entrevistas com as pessoas, com mendigos, na beira de estrada e tal. Que a vida depende de você pra fazer mudança, e que temos que eliminar aquilo que sobra, 'alguém quer trazer a carteira aí que está no bolso, pra gente ver o quanto que a gente carrega que não utiliza'. E foi tirando as coisas da carteira do cara, e descartando. E foi falando, 'olha como a gente carrega coisas inúteis no nosso dia-dia. $E$ isso aqui é o que a gente faz na empresa, esse programa da Embraer não vai só servir pra Empresa, mas pra nós pra vida toda'. E o que os caras pensavam que quem for vagabundo está fora da fábrica. E lá trabalhavam 12 caras na direita (do avião) e 12 na esquerda. Estava 'bombando' né. Aí eles resolveram mudar, com essa implantação do novo modelo operacional, desligaram 12 pessoas, e aí o primeiro turno trabalhava na direita e o segundo na esquerda. Então a cada turno um lado ficava parado. Eles foram eliminando vários métodos onde perdia-se o tempo. E depois ainda quiseram dar mais uma 'arroxadinha', aí demitiram mais 6 do primeiro turno, aí ficou os 6 do primeiro turno na direita, e os 12 na esquerda, aí mandaram mais 6 do segundo turno embora, e ficou seis em cada turno. Aí no final mandaram mais 6 funcionários, e então a mesclada ficou um turno só hoje." (Vitor e Adriano, entrevista de pesquisa, novembro de 2011). 
Esse processo mescla um novo modelo de regulamentação do trabalho com a utilização de princípios do taylorismo. A construção do consentimento na fábrica convive com a coerção na construção e consolidação da hegemonia de uma classe sobre as demais dentro da sociedade e dentro da fábrica. O consentimento prevalece sobre a coerção na consolidação de um domínio social e, sendo assim, a perspectiva de construção do poder por meio do consentimento é mais efetiva do que somente a utilização da coerção.

O sindicato descreve a aplicação de um programa de "excelência empresarial" na Embraer, no qual a pressão em cima dos trabalhadores é muito grande e o medo das demissões assombra os trabalhadores:

\begin{abstract}
"O Programa Embraer de Excelência Empresarial, que pra nós é Programa de Exploração de Empregados da Embraer. É complicado. Chega o supervisor, o técnico de segurança, o agente de melhoria contínua e pega um monitor. Então ficam cinco pessoas. E eu estou aqui cravando o rebite, aí o cara pega um cronômetro. Então, eu já tenho uma pressão natural por ter cinco chefes me olhando. Eu tenho que fazer com perfeição. Aí o cara chega e fala que vai cronometrar. Então, somos quatro trabalhando aqui na operação, nessa peça. E eles estão lá cronometrando. Aí a gente acaba essa peça e o cara (supervisor) fala tira um, e faz vocês três agora, cronometra. Tira mais um. Aí o cara num olha pro lado, num fala com o companheiro do lado, num vai no banheiro, ele está ali focado pra num errar e tentando ser o melhor possível. Acabou aquela medição, eles falam assim olha, vocês com quatro, (que conversavam, iam ao banheiro, fumar um cigarro e etc.) então, se falta um, eles param o cronometro. Se você passa a mão na testa eles questionam. Coçou a batata da perna, eles te questionam. Por quê eles tinham o antes 'aqui vocês fabricam 10 peças, em 4 pessoas'. Cronometrou, e em 2 estava fazendo a mesma operação, porém estava produzindo 20 peças. Mas por que eles estavam agarrados ao trabalho. Aí, o chefe já num ia muito com a cara de um, e fala 'vocês dois, vão trabalhar ali naquela sessão ali'. Então lá tinha 6, agora deixa os quatro lá trabalhando. Só que a partir de agora vocês vão ter que fazer 20 peças em duas pessoas. Aí a pressão é enorme em cima do cara, porque só tem dois e eles têm que cumprir as 20 peças exigidas. E aí começou as demissões." (Vitor e Adriano, entrevista de pesquisa, novembro de 2011).
\end{abstract}

As comissões para a negociação da PLR, na verdade, não representam os trabalhadores e são consideradas pelos dirigentes do sindicato como "fantoches" da empresa, para apresentá-la como democrática e aberta ao diálogo:

“A última vez que nos reunimos na comissão, a empresa falou que ia discutir apenas alguns itens, mas a empresa tem que discutir tudo. Do quanto vai ser 
dividido e da forma que vai ser dividido. Aí eu falei 'mas então nós viemos fazer o que aqui então?! Se vocês chamam isso de comissão, e ela num tem autonomia pra nada, é uma maneira de vocês fazerem dela um fantoche justamente pra homologar e não ter problema.' (...) E a comissão falou que queria mudança, e a empresa falou que tudo bem, eles iriam discutir com o conselho, eles disseram, 'vocês não tem autonomia pra discutir isso.' Foi aí que eu falei, 'então pra quê essa comissão?' foi aí que nós começamos a falar com o trabalhador 'a empresa está aí, está na mão dela, ela não aceita, não quer discutir e manipulam tudo" (Vitor e Adriano, entrevista de pesquisa, novembro de 2011).

O processo de construção do consentimento interno à fábrica conta com a responsabilização e imputação da culpa no trabalhador no que diz respeito ao seu desempenho no processo de trabalho, a ponto de até mesmo culpar o próprio trabalhador pelos acidentes na empresa:

\begin{abstract}
"O cara se machuca. Aí vem um time, resolve o problema, tira foto, e entre eles resolvem o problema, da maneira que eles acham certo. E falam olha, foi culpa dele, por que se ele tivesse feito da forma correta, num teria acontecido esse acidente. Aí eles fazem um DSS - Diálogo Semanal de Segurança. E lá colocam todos os funcionários da seção numa sala e colocam lá a foto da máquina, que o cara colocou o dedo no lugar errado, faz de tudo pra enfiar na cabeça dos trabalhadores o que foi feito errado, e o que deve-se fazer pra não se acidentar mais. Aí o técnico de segurança vem com uma lista, todo mundo assina, então estão todos cientes que aquilo não se faz mais. A CIPA nem sequer fica sabendo, porque também, o número de cipeiros não é suficiente." (Vitor e Adriano, entrevista de pesquisa, novembro de 2011).
\end{abstract}

Assim como culpa e responsabiliza o trabalhador, a empresa procura esconder acidentes de trabalho para que não sejam registrados nos órgãos responsáveis e ela não "perca pontos" nos seus programas de excelência empresarial (programas que são fundamentais na apresentação do balanço da empresa para a negociação de ações no mercado financeiro), além de permitir a cobrança de índices questionáveis de atuação dos trabalhadores:

"A empresa não reconhece os acidentes de trabalho. Se o trabalhador quebrar o braço ela pede para o cara ficar lá carregando papel, pra não dispensar, não ir para o INPS, pra não emitir a CAT dele. Aí depois se tiver uma sequela, não documentou, não fez nada, rua. O 5S (Programa de excelência empresarial) também faz parte do programa. Tem um grupo que faz auditoria do $5 \mathrm{~s}$, se eles acharem, por exemplo, um copo de plástico dentro do lixo do banheiro, ou se tem um papel caído no chão do banheiro, eles tiram fotos, aí tem umas 'carinhas', verde, vermelha e amarela, a vermelha você está ruim. A verde é um sorriso. O próprio trabalhador, que 
fica há uns 200 metros de distância do banheiro, vai lá, tira a foto, aí eles têm umas contas lá, que eles perdem pontos, e esses pontos diminuem o PMS, que diminui a PLR, e o trabalhador sai na seção em grupo anotando o que está errado, e isso diminui a PLR deles." (Vitor e Adriano, entrevista de pesquisa, novembro de 2011).

Até "senhas" para os trabalhadores foram usadas pelas empresas em conjunto com alguns grupos políticos para que os trabalhadores aceitassem sem conflito as demissões que viriam naquela conjuntura:

"E naquela época o engodo da Articulação (grupo político) era dizer que na GM sairia um numero ' $x$ ' de pessoas e entraria um ' $x$ ' de indicados, por exemplo, sairia um tanto de aposentados, e eles receberiam uma senha que poderia indicar uma pessoa para o lugar deles, isso é um absurdo. Principalmente dentro do sistema do Capital. Mas eles conseguiram embutir isso na cabeça dos trabalhadores. O tempo passou e os trabalhadores viram que nada aconteceu." (Roberto, entrevista de pesquisa, setembro de 2011).

Um dos gerentes dos Recursos Humanos da Embraer revelou a um dirigente do sindicato a estratégia que a empresa adotaria logo depois da sua privatização e de uma pequena paralisação dos trabalhadores. Esta estratégia tinha a intenção de provocar o refluxo nos movimentos contestatórios presentes na empresa e com isso ter a possibilidade de impor sobre os trabalhadores as suas condições:

\footnotetext{
"Pouco depois houve uma greve em que 430 trabalhadores do segundo turno sentaram lá pra conversar. A empresa deu 430 advertências, porque eles pararam pra discutir. Acho que já era a parte da discussão do abono. A empresa pagou o abono e deu todas as advertências. Nós fomos questionar depois, o cara do Rh virou e falou assim 'o importante é abrir a ferida, a cicatrização, ela é demorada. E o trabalhador nunca vai esquecer.' Nós sabíamos que não podíamos, mas a ferida ficou aberta. A empresa não negocia, não senta e conversa, ela impõe as condições.(...) E um detalhe, é que depois de ela ter feito isso com os trabalhadores, nós cogitamos outra paralisação, e os trabalhadores ficaram receosos. Eles conseguiram dar uma freada na galera. E naquela mesma semana mandaram uns 10 embora, pra mostrar pra fábrica. Aquilo repercutia na fábrica, e criou aquele clima tenso, de medo. A empresa não respeita o trabalhador de maneira nenhuma." (Vitor e Adriano, entrevista de pesquisa, novembro de 2011).
}

Dessa maneira, a empresa articula táticas para obter o consentimento dos trabalhadores, com a utilização da coerção e da repressão quando visualizam que a conjuntura política e econômica é favorável. De todo modo, essas estratégias de construção e 
conformação de um consentimento fabril também encontram a resistência de um grupo de trabalhadores que procura apresentar uma perspectiva política oposta, que não aceita como inevitáveis as mudanças implementadas e procura apresentar novas possibilidades aos trabalhadores, ou ao menos procura resistir na aplicação dessas "medidas neoliberais".

Como Gramsci afirma, a perspectiva de construção da hegemonia a partir do consentimento pela classe dominada é importante, particularmente na disputa em torno de valores e ideias a respeito de como a sociedade funciona e deve funcionar. A construção do consentimento, ainda que apresente desvantagens devido ao fato de ser uma luta desigual, oferece possibilidades para os trabalhadores na disputa dos valores envolvidos na sociedade e na fábrica, assim como combate o discurso ideológico-hegemônico dos empresários. Sua resistência pode proporcionar benefícios políticos significativos para os trabalhadores nessa luta. Cabe agora descrever de forma detalhada como se estabeleceram essa resistência e a luta do sindicato em relação às medidas que alteram a legislação trabalhista, partindo, principalmente, da representação que os dirigentes sindicais fazem da atuação do sindicato frente essas medidas.

\subsection{Resistências no Sindicato dos Metalúrgicos de São José dos Campos e Região}

O Sindicato dos Metalúrgicos de São José dos Campos e Região tem um histórico de luta pelos direitos dos trabalhadores e resistência contra as ofensivas empresariais que buscam desregular os direitos e aplicar novas formas de produção nas fábricas da região. A desfiliação do sindicato em relação à Central Única dos Trabalhadores (CUT), por esta não representar suas principais reivindicações e estar atrelada ao governo federal, como afirmam os dirigentes, coloca a perspectiva de um horizonte pouco explorado pela academia, de um sindicato que atua, ou pelo menos se posiciona, como um sindicato desatrelado dos interesses tanto de empresários como do governo federal.

Embora o sindicato esteja atrelado a uma central sindical ainda incipiente no cenário sindical e sua gestão represente um grupo minoritário diante de outras tendências existentes no movimento sindical, ele possui grande importância por se colocar contrário às medidas de desregulamentação da legislação trabalhista e possuir uma ação efetiva nesta direção. $O$ sindicato exerce uma luta efetiva que gera grande influência nos sindicatos mais contestatórios e combativos do país. Diante disso, cabe entender a representação, 
posicionamento e ação efetiva que o sindicato desempenha em relação às medidas da desregulamentação das leis trabalhistas.

\subsubsection{Reestruturação produtiva, sistema capitalista e resistência}

Os dirigentes do sindicato afirmam-se contrários ao sistema capitalista e questionam a reestruturação produtiva que modificou o mundo do trabalho nas últimas décadas, colocando os direitos dos trabalhadores em risco:

"Então essa reengenharia, a reestruturação produtiva, que aconteceu no início da década de 1990 é o caos em que estão hoje os trabalhadores - nós temos hoje salário rebaixado, se nós formos comparar com a década de 60 e 70, menos direitos do que tínhamos no passado. Hoje eles estão fazendo todas as reestruturações para saber se eles acabam, por exemplo, com a CLT. A CLT hoje que eles falam que é antiquado, não é antiquado a CLT, é que eles estão tentando retirar direitos que têm os trabalhadores, não só aqui, mas no mundo" (Roberto, entrevista de pesquisa, setembro de 2011).

Nas regiões abrangidas pelo sindicato, a reestruturação produtiva atua em "sistema de troncos", em que há diversas pequenas e médias empresas que fornecem os materiais necessários às grandes empresas. Como exemplos, podem ser citados, entre outros, o tronco automobilístico, utilizado principalmente pela GM, e tronco do setor de aviação, que tem a Embraer como principal empresa utilizadora. Como uma dessas regiões, a Chácaras Reunidas possui uma lógica própria ligada à reestruturação produtiva, como descreve um dos dirigentes responsáveis pelo atendimento aos trabalhadores na região:

"Isso faz parte do modelo produtivo, desse modelo que nós estamos vivendo do séc. XXI, que vem dessa nova mudança no processo produtivo, que tem a reestruturação produtiva, os novos métodos de gerenciamento, envolvendo o trabalhador diretamente. A organização territorial do sistema produtivo. Você pega o sistema tronco aqui... as fornecedoras próximas, pra evitar custo de transportes... Então tem toda uma lógica, pensada, construída, para que haja a Chácaras Reunidas, que é a Zona Sul. Entendeu?! Existe uma lógica. Existe uma lógica mesmo, e de extrair e combinar as duas 'mais-valia'. Nas grandes a 'mais-valia' é absoluta e relativa, e aqui é absoluta mesmo. É arrancar o sangue dos trabalhadores, das mulheres, das meninas novas, aqui é um 'frigorifico', tira o coro - vivo dos meninos mesmo. E só num está tirando mais porque a gente num deixa. É guerra todo dia, toda noite, é guerra toda hora. Então o sindicato tem resistido muito. $\mathrm{O}$ sindicato vem enfrentando graves problemas, porque existe aqui o braço armado da polícia, todo dia, toda greve a gente vai preso, prisão toda hora. Empresas aqui 
recorrem, então você chega aqui na fábrica de manhã, têm 6,8 viaturas. Estão usando a polícia mesmo. O pessoal almoça dentro da fábrica, janta, está levando cesta básica, cesta de natal, peru no final do ano. E ninguém faz nada, e a gente tem que enfrentar tudo isso. Mas é igual eu te digo, aqui todo dia a gente tem que matar 1 ou 2 "leão"... então é o time nosso que faz isso, entende?!" (Domingos, entrevista de pesquisa, outubro de 2011).

A desregulamentação das leis trabalhistas está ligada, para os dirigentes do sindicato, à reestruturação produtiva e há um interesse dos empresários em aplicar novas medidas que retiram os direitos dos trabalhadores:

"Existe diariamente uma política da patronal de flexibilizar tudo. Desregulamentar tudo aquilo que está regulamentado. Isso é a essência da reforma sindical e trabalhista que está no congresso nacional. Enquanto o congresso num avança, na prática, os patrões fazem. Essa safadeza de precarização, de descumprimento das obrigações trabalhistas, elas tiram a previdência, o fundo de garantia, a convenção coletiva, a CLT, tudo aquilo que está regulamentado, que patrão num respeita, tem por trás essa orientação política que é preciso flexibilizar. Certo?! Acabar com tudo que é regulamentado" (Roberto, entrevista de pesquisa, setembro de 2011).

A resistência ao sistema capitalista é expressa no trabalho de base que o sindicato realiza com os trabalhadores e na sua atuação diante das ofensivas empresariais:

"Ou nós revolucionamos nosso trabalho em base, construímos dois mil ou três mil ativistas, conscientes, preparados, que onde estiver reproduza essa resistência consciente, priorizada, que separa o que tem que ser feito hoje, amanha e depois, ou a gente vai correr atrás da luta e do Tom e Jerry, corre todo dia. O patrão tirando e a gente tentando repor, nós temos que combinar três coisas aqui: a Resistência, no sentido de repor e recuperar o que eles roubam dos trabalhadores, mas criar novos instrumentos pra que os trabalhadores possam se defender, e aí entra uma serie de coisas reduzindo a jornada, construindo a organização do local de trabalho, pra combater o problema onde ele nasce, no coração da máfia, no coração da fábrica, e ao mesmo tempo, apresentar um projeto político, ou antagônico ou o que tem aí. Contra o Capitalismo dizendo: onde há o Capitalismo, há miséria e fome, há desgraça e pobreza, há exploração, há precarização. O Capitalismo mata as pessoas. Por isso, Morte ao Capitalismo. Nós temos que falar isso. Então, nossa responsabilidade nas assembleias não pode ser uma responsabilidade apenas econômica, sindicalista, ela tem que cobrir essas três esferas do debate e da luta" (Domingos, entrevista de pesquisa, outubro de 2011).

\section{$\underline{\text { 3.2.2 Sindicato e a estrutura sindical }}$}


O Sindicato dos Metalúrgicos de São José dos Campos e Região afirma-se contrário à maior parte dos sindicatos e teve como posição abolir o salário do sindicalista, que é pago pelo sindicato ao dirigente sindical, medida que tem por fundamento, segundo um dos dirigentes do sindicato, permanecer nas mesmas condições que os trabalhadores:

\begin{abstract}
"Se amanhã tivesse uma rebelião, e eles dissessem: 'olha, hoje nós vamos fechar todos os sindicatos'. Perfeito. Nós estaríamos em perfeito acordo. Vamos se organizar! Porque a massa organizada por si só, ela tem muito mais força de luta do que através do sindicato. Por que o sindicato hoje é uma mola protetora das empresas, a grande maioria dos sindicatos por aí num presta. Grandes salários. Os dirigentes recebem salário a mais por aí. Quando nós entramos em 1990 já cortamos salário. Já abolimos salário de sindicalista. Por que a categoria te dá o carro pra andar, se você gastar almoço essas coisas a categoria te paga. Você ganha o salário da empresa, porque você está afastado, então o que você tem além de custo, ou algum salário a mais? Mesmo porque, se o trabalhador chega pra conversar com você, 'escuta a minha situação está assim...', se a sua estiver a mesma, vocês vão conversar de igual pra igual, se eu pagar um salário a mais pra você, você vai dizer 'a situação num está tão ruim assim né?!'”(Roberto, entrevista de pesquisa, setembro de 2011).
\end{abstract}

Para o sindicato, a base é fundamental para as conquistas e a luta:

"Porque o problema é de base. Se o núcleo operário for arrebentado, em qualquer partido operário ele explode. É impossível, porque você passa a falar por você. Não é mais representante, aquilo que eu estou falando, num sou eu, é a representação, é quem eu represento que está falando". (Roberto, entrevista de pesquisa, setembro de 2011).

Um dos problemas que o sindicato enfrenta diretamente é o da burocratização que assolou vários outros sindicatos e impede a luta dos trabalhadores, principalmente por causa do distanciamento em relação à base e o crescimento da vaidade de diversos sindicalistas:

"O assedio do sistema capital é muito grande, num pensa que é fácil segurar ele. Eu sei o que nós passamos aqui. Um sindicato pequeno como esse aqui, o sistema de burocratização é muito grande, já me atingiu... cada vez que nós damos uma batida no sistema de burocratização, dentro de uma maquininha como essa aqui, é carro, passe de ônibus, celular... parece tão banal. Porque qual o problema de quando você passa a ser dirigente, é que toda vez que você passa a ser dirigente, principalmente quando você passa a ser reconhecido, pelo nome e tal, você passa a olhar pra frente, outro dirigente, você num olha mais pra trás, num se compara mais com a base. Então você vai se distanciando. E é coisa pequenininha, num é coisa grande não". (Roberto, entrevista de pesquisa, setembro de 2011). 
A estratégia do sindicato, apesar de se afirmar como classista e combativo na defesa dos trabalhadores, não é pela utilização de greve como um instrumento de resistência e negociação em todos os casos, embora diante do sistema capitalista essa talvez seja uma das medidas efetivas para os trabalhadores obterem o que almejam:

"Num tem saída, essa é a saída. Num existe operário que queira greve. Todo mundo quer levantar cedo, na paz, ir pro seu trabalho. Você olhar no jornal e ver que te deram $15 \%$ de aumento, todo mundo queria uma vida assim, mas no sistema do capital isso não existe". (Roberto, entrevista de pesquisa, setembro de 2011).

Para o sindicato, a CIPA (Comissão Interna de Prevenção de Acidentes) tem que fazer o papel do sindicato dentro da fábrica:

"É o cara ser Cipeiro, e ter hoje o papel de cipeiro na fábrica, e dentro desse papel de cipeiro ter um papel reivindicatório, saindo da segurança, e entrando na parte reivindicatória de condições de trabalho, eu sei que condições de trabalho refletem diretamente na segurança. Mas a gente usa os Cipeiros pra poder fazer o trabalho de conscientização do movimento como um todo e não somente da CIPA como quer os patrões. Os patrões só suportam cipeiros de luta porque tem estabilidade". (Roberto, entrevista de pesquisa, setembro de 2011).

Outra proposta defendida pelo sindicato é a presença do delegado sindical nas fábricas, pelo menos um delegado a cada cem trabalhadores:

"Por que as empresas, na sua esmagadora maioria, pelo menos não as da nossa base, não aceitam os delegados sindicais. Que inclusive, está na nossa convenção coletiva, a proposta de que passou de 100, tem que ter 1 delegado sindical. Mas as empresas não cumprem. E uma das prioridades da nossa campanha salarial foi ter na pauta o delegado sindical, na maioria das fábricas. Conseguimos em várias fábricas. Ele vai fazer o papel do sindicato no interior da empresa. Fazendo as pós-reivindicações, aquelas que são internas. Porque tem um monte de irregularidades que acontece no dia a dia das empresas que num são passadas pra nós, nós não colocamos em pauta ás vezes, por que é uma coisa que por ser do dia a dia, quem deveria resolver esse problema seria o delegado sindical. Ficaria a segurança do trabalho com os Cipeiros, e os problemas internos ficariam com o delegado sindical." (Roberto, entrevista de pesquisa, setembro de 2011). 
As comissões de fábrica seriam um importante instrumento de luta do sindicato internamente às fábricas, fazendo o papel do sindicato:

"Nós tínhamos uma comissão de fábrica, comissão é essa que usa a estrutura dos delegados sindicais, cipeiros. Essa comissão de fábrica trabalhava diretamente nas reivindicações, então pras reivindicações internas, do dia dia, não precisa estar o sindicato, se as comissões foram representativas e combativas, elas podem dirigir uma fábrica tranqüilamente. $\mathrm{O}$ sindicato ficaria com o papel de simplesmente de homologar". (Roberto, entrevista de pesquisa, setembro de 2011).

\subsubsection{Participação nos Lucros e Resultados (PLR)}

A PLR apresenta-se como uma das principais medidas da desregulamentação das leis trabalhistas e sua finalidade não é contribuir com os trabalhadores provendo financeiramente os lucros ou resultados obtidos pela empresa, mas sim prover um salário variável que é usado em interesse dos empresários e do governo:

"Então a PLR é uma parte desse processo que nós chamamos, que é mudança do salário, para o salário variável, você ter um salário menor, pra você pagar menos impostos, e uma PLR pra você otimizar o processo, envolver os trabalhadores na qualidade do produto, ter o tempo menor pra produzir, ter o trabalhador envolvido na entrega, na satisfação do cliente. Então a PLR é uma baita saída inteligente dos caras, transformando o trabalhador no próprio gerente dele mesmo. Ele vai fiscalizar, vai conter os gastos, vai fiscalizar o outro, isso é um problema serio" (Domingos, entrevista de pesquisa, outubro de 2011).

De acordo com os diretores do sindicato, a PLR está relacionada com a Reforma

Trabalhista, na intenção de se acabar com a jornada de trabalho:

“A PLR é a porta de entrada da Reforma Trabalhista. É transformar o salário do trabalhador em salário variável. É fazer o que existe hoje no comércio, é trabalhar por produção. E aí acaba com a jornada, e tudo que é regulamentado vai começar a cair por terra" (Domingos, entrevista de pesquisa, outubro de 2011).

Para os trabalhadores ligados ao sindicato, a PLR deriva do abono que era requisitado no final do ano pelos trabalhadores em diversas empresas da região: 
"A Participação de Lucro dos Resultados, começou na década de 80. Nós começamos a fazer um trabalho, e os trabalhadores começaram a parar no final da década de 80. Pra reivindicar o abono de final de ano, cada um dava um apelido, por exemplo, lá na Phillips era o porquinho, na GM o pessoal pedia o frango, tudo que tinha na ceia de natal. E isso começou a proliferar por aí, pelas fábricas todas, aí a Patronal muito esperta como sempre foi, ela viu que tinha um sentimento da base e começou a fazer as suas adaptações. Então eles disseram assim: 'esse porquinho, que vocês queriam no final do ano, ele não tinha vínculo nenhum, nada com nada'. Mas queria porque queria. E parava a fábrica no final de ano. E como isso se proliferou muito entre as fábricas, o que os patrões fizeram, foram regularizar os abonos, e deu-se o nome de PLR, Participação de Lucros de Resultados" (Roberto, entrevista de pesquisa, setembro de 2011).

De acordo com o sindicato a patronal adaptou o abono existente no final do ano, estabelecendo regras e metas para alcançar o valor que os trabalhadores estipulavam, instituindo com isso a concorrência entre os trabalhadores:

"E a Patronal muito esperta colocou as regras e ela fez um trabalho de tentar fazer com que a PLR fosse uma adaptação dos trabalhadores ao sistema, só que uma adaptação muito mais rígida. E tentam abrir uma luta dos trabalhadores contra eles mesmos" (Roberto, entrevista de pesquisa, setembro de 2011).

Houve algumas tentativas iniciais de aplicar a PLR nas fábricas com valores diferenciais, por setores ou equipes, condicionando os afastamentos legais dos quais os funcionários têm direito dentro da empresa, que foram questionadas pelo sindicato:

"Então foi de diversas formas que ela tentou colocar a PLR, a primeira foi que a PLR era um salário de cada um. Um salário a mais pra cada um. Nós fomos contrários, por que dividia a fábrica. Depois tentaram fazer o seguinte: Disseram que era por setor da empresa. Nós fomos contra. Conseguimos quebrar. E disseram, PLR pra todos. Só que tem uma regra importante dentro da PLR que nós temos que quebrar que é a regra das metas. Por que eu coloco as metas, e tento enquadrar o trabalhador de acordo com a minha produção. Então as metas que são discutidas por aí, era que, não podia ter faltas, atestados médicos, e qualquer tipo de falta. Eles tentaram colocar de todo jeito. E nós cortamos, doenças, férias, casamento. Tiramos das metas todos esses pontos. Tirando todos esses pontos você dá uma trégua pro trabalhador de não sofrer pressão do próprio companheiro" (Roberto, entrevista de pesquisa, setembro de 2011).

A linha do sindicato foi realizar a denúncia da PLR, principalmente em relação ao aumento de doenças que poderiam trazer aos trabalhadores, mas o questionamento enfrentou 
grandes dificuldades devido ao valor financeiro pago aos trabalhadores e a necessidade do dinheiro pelos mesmos para o pagamento de dívidas, em muitos casos:

\begin{abstract}
"As empresas então vieram com a PLR para incentivar os trabalhadores a manter a produtividade. Aqui a linha foi denunciar a PLR para forçar a negociação sem metas e sem condições. Isso só se consegue em partes, pois existem metas que são colocadas e, nesse ponto, o que o sindicato tem feito é denunciar a PLR, como um gerador de aumento das doenças do trabalho. Mas a negociação da PLR, é mais difícil, pois já faz parte do ganho do trabalhador. Essa questão é mais difícil por isso, você tem que fazer o acordo e denunciar a cada momento esses mesmos acordos. Essa é uma daquelas flexibilizações que não foi possível barrar. Mas ainda temos essa posição classista, de dizer que os trabalhadores merecem aumento real sempre, mas há o problema de os trabalhadores gastarem esse valor por antecedência e dependerem de recebê-lo no final" (Geraldo, entrevista de pesquisa, setembro de 2011).
\end{abstract}

Ainda de acordo com os dirigentes do sindicato, a PLR possui uma estratégia na forma com ela é paga aos trabalhadores, com um impacto preciso na campanha salarial:

“A PLR é um engodo do salário. Ela é um salário variável. Essa é a função hoje da PLR. Eu te pago PLR. Quais os meses que eu te pago? A primeira parcela vem em junho ou julho. A segunda parcela é dezembro ou janeiro. E porque eles fazem isso? Quando chega a junho ou julho, pelo acumulo da inflação, o trabalhador já está até o pescoço. Em junho ou julho ele recebe a primeira parcela, o que acontece com ele, paga suas contas. E quando chega no meio de setembro ele amortece a campanha salarial. Então eu não vou fazer grandes lutas pelo salário, por que a minha vida, o meu cotidiano foi amortecido aqui. Então quando chegar, eu num preciso de uma briga grande por que eu já a amortizei lá atrás" (Roberto, entrevista de pesquisa, setembro de 2011).

Essa forma de pagamento garante um aumento salarial menor do que o necessitado pelos trabalhadores em boa parte das empresas, libera o gasto fixo das empresas, enfraquece a campanha salarial, aumenta a produtividade e garante uma menor quantia no pagamento dos impostos:

"E a Patronal como num vai dar um aumento muito grande por aqui, por ter passado batido ali atrás, não tem um grande aumento de salário. Não tendo o seu aumento grande de salario ela fica com o sua folga de caixa, uma grande folga. Ela num fica com o gasto fixo, e fica com um gasto grande variável, que não tem impostos, e fica com o gasto fixo muito pequeno. Então essa é a visão da PLR, ela fez com que os trabalhadores trabalhassem mais e ganhassem menos. Essa é a grande jogada da PLR. Quem fez isso foi gênio, 
ele pensou em como ia amortizar a briga dos operários, pegou uma coisa imediatista, jogou no salário, por que se você diluir a PLR no ano, por exemplo, dá quase mais um salário para o cara" (Roberto, entrevista de pesquisa, setembro de 2011).

O impacto do valor da PLR age diretamente na aceitação do trabalhador, que pouco questiona sobre os condicionantes ligados ao pagamento e o impacto dessa medida em seu futuro. Há um interesse atrelado no pagamento da PLR entre os empresários e o governo, principalmente no impacto dessa medida na Previdência Social:

"Você pega a GM dá quase $\mathrm{R} \$ 13.000$. O cara ganha $\mathrm{R} \$ 2.000$ dá quase $50 \%$ mensal do salário do cara. Esse camarada vai sair de lá com um salário baixo. E por que o governo incentiva como eu não tenho aumento aqui, o governo incentiva as empresas a dar PLR, por isso não cobra impostos. Por que lá na frente, quando eu aposentar, eu aposento com o salário baixo. É casado. Os mesmos que são patrões são governo" (Roberto, entrevista de pesquisa, setembro de 2011).

O fato da negociação da PLR ser por uma empresa possui uma ambivalência para os trabalhadores, já que isso possibilita um avanço do movimento coletivo, ao mesmo tempo em que o rendimento é individualizado:

"É por empresa. Já enfraquece. Mas ela é uma faca de dois gumes. Por exemplo, diante de uma campanha salarial ela enfraquece, por que os caras querem ver o dinheiro no bolso de imediato, mas ela alavanca, por outro lado, uma outra luta, o que os trabalhadores mais querem. Por que a PLR nada mais é do que salário variável, então mesmo ela sendo por fábrica, ela acaba aferindo na coletividade, por que você tem que ir lutando, fábrica por fábrica. Mas é uma luta ruim por que ela tira da coletividade. E tudo que tira da coletividade é ruim, por que alguns vão ter mais do que outros. $\mathrm{Na}$ individualidade dá nisso. Na GM por exemplo, o cara tem muito mais vantagens do que o cara que trabalha na Chácaras Reunidas" (Roberto, entrevista de pesquisa, setembro de 2011).

Para os dirigentes do sindicato há um problema de geração no movimento operário, já que os trabalhadores mais jovens acabam aceitando mais facilmente a PLR, devido principalmente ao fato de esta possibilitar ganhos financeiros imediatos:

"Os mais jovens são piores, porque já entram de cabeça no sistema, com o salário variável. O que eles vão tentar fazer no futuro é cada vez mais colocar o trabalhador como variável também. Com três meses de contrato, seis meses, tem contrato até de dois anos. Que é sazonal. O trabalhador vai 
ser sazonal. Então além de aposentar com um valor menor, vai levar mais tempo pra se aposentar. Então os trabalhadores que num prestam atenção hoje, a situação dele vai ser muito ruim amanhã" (Roberto, entrevista de pesquisa, setembro de 2011).

As metas ligadas ao cumprimento da PLR em muitas empresas estão causando uma série de doenças nos trabalhadores, principalmente doenças psíquicas, relacionadas à pressão e à cobrança que os funcionários enfrentam para atingi-las:

\begin{abstract}
"Então quando eles ligaram essas metas eles conseguiram dar esse salto. Foi um salto de qualidade pra eles. Em contrapartida onde não está presente a organização sindical, a epidemia da doença ocupacional é também uma coisa bem visível. Por que o que acontecia, as máquinas, no passado mutilavam os trabalhadores externamente. Perdiam-se dedos, braços e etc. hoje é pior a espécie de mutilação, porque estoura o cara internamente. Tem gente que num consegue segurar um copo d'água. Pessoas novas. (...) A LER, que é a Lesão por Esforço Repetitivo, essa se tornou epidemia hoje, se assim podemos chamar. As doenças psíquicas, dentro da fábrica são muito comuns, pela pressão que o individuo sofre. Já existia, mas dentro de uma certa normalidade. Mas hoje, com a pressão da fábrica, do trabalho, do mundo de hoje faz com que a doença psíquica se alastre entre os trabalhadores, como depressão, estresse, síndrome do pânico, e eu posso dizer pra você que até loucura completa do operário. Nós temos muitos casos hoje. Então nós temos que começar a reivindicar pra que nos ambulatórios médicos das fábricas ter obrigatoriedade de ter um psicólogo, um psicanalista, essa necessidade já começa a surgir já. São coisas que você num via no passado" (Roberto, entrevista de pesquisa, setembro de 2011).
\end{abstract}

$\mathrm{O}$ aumento do consumo de drogas pelos trabalhadores, inclusive com o consumo daquelas mais pesadas, está diretamente relacionado às metas no processo de produção:

\footnotetext{
"Então, eu estava falando que o uso hoje é mais acentuado do que no passado. No passado ocorria mais o uso da Maconha. Por que a maconha é tranquilizante, então havia maior quantidade de consumo pra que o trabalhador aguentasse o ritmo de trabalho. Pra cabeça ficar mais tranquila, pra poder trabalhar. Hoje as drogas são mais pesadas, e o consumo de álcool entre os trabalhadores é alto" (Roberto, entrevista de pesquisa, setembro de 2011).
}

Porém, não é possível elucidar se esse aumento do consumo está relacionado ao acesso mais fácil a essas drogas mais pesadas ou deriva diretamente do fato de os trabalhadores terem que utilizá-las para garantir o cumprimento das metas no processo produtivo. 
Nas empresas em que a PLR foi aplicada com metas por setor ou equipe, a cobrança, a concorrência interna entre os trabalhadores e o assédio moral que os funcionários sofrem é desfavorável ao coletivo de trabalhadores:

\begin{abstract}
"Quando eles tentaram implantar esse tipo de participação de resultado. E nós conseguimos quebrar. Que é colocar por setor, o que é pior porque um setor ia brigar com o outro. A meta do setor. Se eles fizessem isso um trabalhador ia tirar sarro do outro, "pô, eu estou tranquilo, meu setor tá tranquilo, tiramos mil reais na PLR, agora no seu setor ninguém quer trabalhar, tiraram 200 contos." E os trabalhadores que trabalham no setor, se você, ou chega atrasado, os próprios colegas do setor dão uma vaia em você. $\mathrm{Na}$ Brahma (fábrica que não possui representação do sindicato) é assim" (Roberto, entrevista de pesquisa, setembro de 2011).
\end{abstract}

$\mathrm{Na}$ Embraer em que a mobilização dos trabalhadores é menor e historicamente possui grande concentração de membros da Articulação Sindical, a PLR não é igualitária, nem a comissão é paritária:

"É o seguinte eles não discutem com o sindicato a Participação de Lucros de Resultado. E eles criaram uma comissão. Ela num é paritária. Então ela pega várias áreas, pega um de cada área, dependendo da área. E da produção ela pega duas. Por exemplo: Tinha cinco mil trabalhadores, e só tinha direito a duas vagas na comissão. O departamento jurídico, onde tinha quatro advogados, tinha direito a uma pessoa na comissão. O setor de defesa tem sei lá, trezentas pessoas, tinha direito também a uma pessoa. E essas pessoas que eles tiravam, eram eles que escolhiam a dedo. (Gerentes, supervisor, diretores)" (Vitor e Adriano, entrevista de pesquisa, novembro de 2011).

A distribuição da PLR na Embraer também possui uma diferença em relação às outras fábricas em que a medida é negociada pelo sindicato - valor único, sem divisões por níveis salariais:

"Então, aí, essa é a primeira regra, $25 \%$ de toda a retirada dos acionistas. Segunda regra: $70 \%$ variável, de acordo com o salário e $30 \%$ fixo. Então, exemplo: Era distribuído R $\$ 1,000$ fixo e $100 \%$ do salário. O fixo, eu ganho 1.000 e você 10.000. Eu pego mil reais fixo, e mais um salário. Ou seja, eu pegaria dois salários de PLR. E você pegaria mil fixo e mais um salário que era dez mil reais, ou seja, dava onze mil reais. Então a divisão era assim, por salário. Pois eles falavam que tinham que contemplar os engenheiros, que tinham cerca de 3600 a 4000 engenheiros, e que eles é que de fato construíam o avião. E nós falávamos que sem a produção também não teria avião. Então, nada mais justo de que o bolo seja dividido em partes iguais. E a empresa falou não" (Vitor e Adriano, entrevista de pesquisa, novembro de 2011). 
A Embraer é a única empresa da região que não negocia a PLR com sindicato. $\mathrm{Na}$ empresa, a PLR gera uma divisão entre engenheiros e as metas são setoriais e inatingíveis:

\begin{abstract}
"Então ela sempre falava pra produção que eles estudaram, e eles eram os "superiores" e que por isso eles tinham que ganhar mais. Então era assim a divisão. E depois a terceira coisa era a PMS - Plano de Metas Setorial Você tinha sua meta, mas o supervisor falava 'nós temos que atingir isso'. Eles criavam metas, e você tinha que atingir $100 \%$ pra você poder pegar $100 \%$ daquilo que a empresa está te dando. E quem tem o controle das metas é a empresa. E você nunca conseguia atingir as metas, e se você atingisse menos de $75 \%$ você num tinha direito à PLR. Só teria direito se atingisse no mínimo $75 \%$ das suas metas, que por sinal eram impossíveis de serem batidas. E se passasse também não teria diferença" (Vitor e Adriano, entrevista de pesquisa, novembro de 2011).
\end{abstract}

Outra diferença é que a PLR é baixa e os trabalhadores não lutam tanto pela medida em comparação com outras empresas pela repressão que há no local de trabalho:

\begin{abstract}
"A briga por PLR é assim: sempre que ia chegando a época de retirada dos acionistas ficava aquele 'alvoroço', 'será que eles vão tirar muito dinheiro, ou pouco? Quanto será?' o interesse do trabalhador era muito grande na PLR. Ainda é. Porque a Embraer começou a 'precarizar' também o salário na questão de Data-base, então hoje ele está apanhando tanto na Data-base como na PLR. A PLR da Embraer hoje chega a dar vergonha. Se você falar de uma empresa, que é de produzir avião, mas quando chega na hora de pegar a PLR, dá uma quantia de $\mathrm{R} \$ 600,00$. Chega a dar vergonha. Você pega uma fábrica do lado, que e bem menor e paga R $\$ 3.000,00$ de PLR, você pega uma GM que chega a uma PLR de 10 mil reais. Então hoje o trabalhador enfrenta a situação de que ele precisa trabalhar. Mas se você falar que ele anseie pela PLR, não cria esperança mais nisso não. E agora também não se movimenta muito pra brigar por ela não. Por que a repressão é muito forte na empresa" (Vitor e Adriano, entrevista de pesquisa, novembro de 2011)..
\end{abstract}

A resistência à PLR, ou a tentativa de alcançar índices financeiros superiores aos trabalhadores sem metas, depende muito da mobilização dos trabalhadores de uma empresa, do sindicato, da situação econômica do país, do índice de desemprego, ou seja, há inúmeros fatores que favorecem ou desfavorecem a luta e a resistência dos trabalhadores em relação à PLR:

"Eles colocam essa meta de absenteísmo por produtividade, em alguns lugares a gente consegue implantar um sistema sem metas - que é a nossa 
proposta - e em outros lugares não há negociação, pois não há mobilização dos trabalhadores. A empresa sobe um pouco o valor e todos aceitam. As empresas jogam nessa miserabilidade que elas geram... então existe acordo desse tipo, o sindicato tem alguns acordos de PLR que foram fechados. Nós sabemos que não são bons acordos, mas naquele momento o trabalhador está interessado em ter aquele valor em mãos. Tem empresas que são piores, pois os trabalhadores não sabem nem se estarão empregados até o final do ano, então aceitam aquele valor mesmo. Porque é interessante pra empresa manter os trabalhadores sob pressão. Em determinado momento, quando há crescimento econômico, fica mais fácil segurar esse tipo de coisa. Mas em momentos de crise, com muitas demissões, pode ser que a empresa se aproveite disso para passar mais alguma coisa de PLR" (Geraldo, entrevista de pesquisa, setembro de 2011).

\subsubsection{Campanha contra o Banco de Horas}

O Sindicato dos Metalúrgicos de São José dos Campos e Região realizou um grande embate contra a aplicação do Banco de Horas em suas fábricas, que se iniciou em 1998 com a sua desfiliação na FEM-CUT/SP (Federação dos Sindicatos Metalúrgicos ligados à Central Única dos Trabalhadores), juntamente com os sindicatos dos metalúrgicos de Campinas e Limeira. Como a própria diretoria do sindicato descreve:

"O Banco de Horas surgiu, junto à patronal, dizendo que o Banco de Horas evitaria as demissões. Então ao invés de demitir eu coloco os trabalhadores de Banco de Horas, vejo qual a quantidade de banco que os trabalhadores têm trabalhado a mais, que têm de horas a mais, ao invés de mandá-los para a rua e demiti-los, eu colocaria esses trabalhadores no banco e o banco pagaria esse período extra, que acumulou no banco, para que não os demitisse" (Roberto, entrevista de pesquisa, setembro de 2011).

Assim, o principal argumento vinculado à implementação do banco de horas na fábrica era o de ele evitar as demissões dos funcionários. Havia uma "necessidade" para os empresários de que os trabalhadores o aceitassem, senão haveria demissões em massa. Dito isso, pode-se concluir que a medida, desde sua primeira apresentação aos funcionários, não foi colocada como um benefício, mas sim como uma solução desagradável que deveria ser aceita pelos trabalhadores sob a pena de um mal maior, o desemprego. A CUT, como relatam os representantes sindicais, abarcou a ideia:

“A própria CUT, no começo da década de 90, passa assumir outra postura a de parceria, de sindicato de colaboração com o empresariado - e durante toda essa década houve um acirramento das posições do setor mais 
combativo, do setor mais à esquerda dentro da CUT, da direção da CUT e o banco de horas acabou sendo um divisor de águas dentro dessa organização. Ele foi proposto pelo sindicato dos metalúrgicos em 96 e em 1998, na hora da negociação da campanha salarial, quando a CUT negociava junto, esse acordo entrou na lista de acordos sindicais que eles assinariam para todos os filiados. Foi aí que houve o rompimento. Sindicatos como o de São José dos Campos, de Campinas e o de Limeira romperam com o acordo e ficaram durante aquele ano sem nenhum acordo coletivo, pois assiná-lo significaria aceitar o banco de horas. O processo de diferenças políticas levou ao rompimento da CUT, levando à formação da Intersindical de Campinas e a Conlutas" (Geraldo, entrevista de pesquisa, setembro de 2011).

Para o Sindicato dos Metalúrgicos de São José dos Campos o banco de horas não representa uma medida aceitável para os trabalhadores, particularmente pelo fato dos trabalhadores não terem a possibilidade de organizar autonomamente o seu tempo livre:

\begin{abstract}
"Porque banco de horas nada mais é do que fazer hora extra sem pagar. Só isso. Não precisa falar mais nada. Não tem uma explicação clara pro banco de horas, por que na prática é assim: 'você faz hora extra aí pra mim e não vai receber. E o dia que eu achar que deve você tira sua folga'. Por que o banco de horas não é assim, você tem banco... Você não pode chegar pro seu patrão e dizer assim, 'olha, eu tenho banco de horas, amanhã não vou trabalhar, não. Eu já tenho no meu banco, tantos dias pra eu descansar, então amanhã eu não volto'. Não é assim. É colocar o peão de acordo com a produção. Então se a minha produção está baixa, 'agora você está no banco de horas'. 'Ah, mas eu num preciso desses dias'. 'Não interessa. Eu preciso. Então tchau pra você'. É assim que eles fazem. Tá certo?! Então num é eu que estou programando a minha vida. São eles programando a produção deles, de acordo com a minha vida, mas do jeito que eles querem. Então num tem nada de bom para os trabalhadores" (Roberto, entrevista de pesquisa, setembro de 2011).
\end{abstract}

A partir dessa resistência efetiva do sindicato, começou anos depois em dezembro de 2007 uma pressão para a adesão ao banco de horas na General Motors do Brasil (GM). Essa pressão era feita por amplos setores interessados na aplicação desta medida - a montadora (GM), o prefeito, vereadores, empresários, e alguns setores da imprensa. A empresa usou o discurso de reestruturação e competitividade e fez a proposta de contratação de 600 vagas de emprego temporárias com redução do piso salarial e a aplicação do banco de horas. O sindicato estava praticamente isolado em sua resistência, era encurralado pela empresa, em uma disputa desigual em que a pressão vinha de todos os lados, além de existirem outras fábricas de cidades próximas como a Ford e a Volkswagen de Taubaté que tinham o banco de horas: 
“A empresa (General Motors do Brasil- GM), há um tempo atrás, fez uma campanha com a prefeitura contra o sindicato, dizendo que isso significaria um prejuízo na quantidade de empregos. Foi uma batalha muito grande. $\mathrm{O}$ sindicato teve que enfrentar tudo e, inclusive setores dentro da empresa, dentro da CUT, trabalharam para ver se aprovavam o banco de horas, mas foram derrotados, por enquanto, já que a questão continua presente, pois ainda há uma postura firme contra o banco de horas" (Roberto, entrevista de pesquisa, setembro de 2011).

Houve uma ampla campanha na cidade de São José dos Campos desses setores da burguesia contra o sindicato dos metalúrgicos:

"Foi uma campanha que pegava os vários setores da burguesia da cidade e os sindicatos patronais, a câmara de vereadores, a prefeitura e até a igreja. Fizeram um documento que dizia que São José dos Campos deveria garantir empregos, dizendo que, caso fosse aceito, a cidade poderia oferecer mais vagas. Ou seja, diziam 'isso vai gerar mil empregos'. O sindicato dizia que não, ou seja, o sindicato é contra o emprego. E foi uma campanha com debate de mesas, com a imprensa por todos os lados" (Geraldo, entrevista de pesquisa, setembro de 2011).

A disputa em torno do banco de horas gerou uma campanha do Sindicato dos Metalúrgicos de São José dos Campos contra a medida a partir de janeiro de 2008, com várias assembleias de trabalhadores da GM, contando com a adesão da base dos trabalhadores do sindicato:

\begin{abstract}
"Na época, esse $\mathrm{DVD}^{42}$ foi entregue para cada trabalhador da GM e, depois, para as demais fábricas. Porque isso aqui foi uma campanha... A GM fazia boletins e entregava para os trabalhadores e foi um debate super difícil e é claro que havia pressão. A Câmara Municipal deu o título de cidadão Joseense para o vice presidente da GM. Era uma pressão constante de campanhas" (Geraldo, entrevista de pesquisa, setembro de 2011).
\end{abstract}

As assembleias contaram com grupos incumbidos pela empresa de convencerem os trabalhadores a aceitarem a aplicação do banco de horas e a redução de direitos. Apesar dessa forte pressão os trabalhadores rejeitaram a proposta da montadora. Esta última, porém, não respeitou a vontade dos trabalhadores em assembleia e manteve o projeto de implementação

\footnotetext{
42 "No caminho das lutas", DVD fornecido pelo sindicato aos trabalhadores na campanha contra o banco de horas. Disponível também em: http://www.sindmetalsjc.org.br
} 
do banco de horas, exercendo uma pressão maior em cima dos trabalhadores, tentando isolar o sindicato de todas as formas, com afirmações de que a GM iria construir outra fábrica se não tivesse acordo com São José dos Campos e que a aplicação do banco de horas traria a criação de mais de dez mil vagas de emprego.

Havia uma tentativa clara de estes setores vencerem os trabalhadores pelo medo, com afirmações de que o sindicato era uma "frente exterminadora de emprego" e que a fábrica iria fechar se não houvesse acordo. A CUT aliou-se a este grupo que se posicionou a favor da redução dos direitos e tentou dividir o movimento dos trabalhadores.

O sindicato realizou uma série de reuniões; fez diversos boletins, jornais panfletos, adesivos, cartazes; vinculou diversas propagandas em radio e televisão; produziu um DVD "Trabalhadores da GM em defesa de seus direitos", que discutia sobre o tema da redução de direitos; criou uma página na internet contra o ofensiva da empresa e o banco de horas; convocou o debate por meio dos meios de comunicação de massa, organizou algumas assembleias, ou seja, realizou uma série de atos no intuito de mobilizar e conscientizar a categoria contra o avanço poderoso destes setores empresariais.

Em junho de 2008, a GM apresentou uma nova proposta na Câmara Municipal e não aos trabalhadores, que era a mesma anteriormente rejeitada no começo do ano pelos trabalhadores. A GM realizou uma paralisação na fábrica, o chamado "locaute", já que fora convocada por chefes de setores; uma paralisação patronal com apoio de dirigentes sindicais da CUT, que romperam com a direção do sindicato com a finalidade de pressionar os trabalhadores para aderirem à nova proposta. Esses dirigentes ligados a CUT propuseram a aceitação do banco de horas em troca da redução da passagem de ônibus, redução no convênio médico, redução no valor das refeições e de abonos aos trabalhadores, que foi rejeitado pela diretoria do sindicato. Em 19 de junho de 2008 houve uma assembleia histórica que rejeitou por ampla maioria a aplicação do banco de horas na GM e a criação de uma nova grade salarial dentro da empresa. Essa vitória transformou o sindicato em um pólo de resistência a perda de direitos trabalhistas:

"Mas foi uma vitória dos trabalhadores nesse último período, pois os tornou pólo de resistência a essa flexibilização que está aí, já que se isso passasse aqui, não restaria um lugar sequer que não tivesse banco de horas. Então essa é a importância da luta dos metalúrgicos. Uma luta que não acaba nunca, pois o tempo todo vem gente fazendo pressão novamente. Aí a GM diz que só trará um novo produto pra cá se aceitarem o banco de horas, senão a fábrica vai acabar fechando... e o pessoal responde que não vai aceitar de 
jeito nenhum. Vamos ver como será a continuidade desse processo. Nós esperamos que os trabalhadores de outros lugares se levantem descontentes com essa questão do banco de horas e nos ajudem a ficar mais tranquilos" (Geraldo, entrevista de pesquisa, setembro de 2011).

Os dirigentes do sindicato admitem que um dia o banco de horas possa ser colocado dentro da fábrica, mas não com a adesão desta direção sindical:

"Se amanhã ou depois ela vier impor aqui em São José dos Campos o banco de horas, pra nós não vai ter problema, porque eu sei que isso aqui vai ter retomada no futuro, se a massa aceitar o banco de horas, e convencer a massa de que aquilo é bom, aí sim eu vejo uma catástrofe total. Porque quando você impõe, alguém vai se rebelar contra. Tudo aquilo de autoritarismo, num sei quanto tempo, pode ser 10,15 ou $20 \ldots$ mas que vai vir à tona, isso vai com certeza. Dizer pra nós que o banco de horas, é a melhor saída que tem pro trabalhador, esqueça! Nós não vamos fazer isso nunca. Tanto é que nunca foi aprovado o banco de horas aqui. Mas eu sei que essa discussão vai voltar" (Roberto, entrevista de pesquisa, setembro de 2011).

Na Embraer, uma das maiores empresas representadas pelo sindicato, que era estatal e foi privatizada em 1997, também houve uma ampla campanha para a adesão dos trabalhadores metalúrgicos à aplicação do banco de horas na fábrica, inclusive com apoio de setores da CUT:

"A proposta que a empresa fez era a seguinte: Se mandaria 930 trabalhadores do setor produtivo embora e teria que implementar esse banco de horas, mesmo assim. E se não tivesse o banco de horas a demissão seria muito maior. Foi feito uma assembleia com os trabalhadores, explicando sobre o ataque da empresa, que ela ia demitir o pessoal do setor e ainda queria colocar o banco de horas e reduzir o salário em 10\%. Foi feita uma grande assembleia onde o setor administrativo não seria atingido" (Vitor e Adriano, entrevista de pesquisa, novembro de 2011).

Da mesma forma que houve uma ofensiva poderosa da GM em relação ao sindicato, com ameaças de demissão e contando com o apoio de dirigentes da CUT, houve também uma disputa na Embraer:

"E o que a empresa fez? Ela colocou numa grande assembleia, tirou todo mundo da fábrica e mandou pra assembleia. Nessa assembleia, a maioria, mesmo sabendo que ia ter demissão em massa e tal, se posicionou contrários ao banco de horas e à redução de salário. Só que na hora da votação estavam em cima do sindicato os dois dirigentes que comandavam o sindicato que 
eram o Toninho e o Toquinho. O Toquinho era da Embraer (CUT) e o Toninho na época trabalhava na GM. O que eles fizeram? O Toninho defendeu contra, e o Toquinho quando ele viu, reparou que ia perder a assembleia, por que os trabalhadores se dividiram assim, a parte do estacionamento era quem era contra, e aí tinha uma rua que ela dividia. E do outro lado tinha umas arvores, e quem era a favor do banco de horas ia pro outro lado. Quando ele viu, ele tremeu. Ele foi muito esperto, ele desceu do caminhão e tremia de nervoso. Aí ele perguntou pra um cinegrafista da globo que estava por ali filmando: 'Você que trabalha com multidões, isso aqui está ou não está um empate técnico?' Aí o cara falou 'Realmente, isso aqui está um empate'. Ele não ia se posicionar, o deixou numa 'sinuca de bico'. Aí eles deram como empate essa assembleia" (Vitor e Adriano, entrevista de pesquisa, novembro de 2011).

Logo após a manobra realizada pelo dirigente da CUT o sindicato afirma que ouve uma nova pressão da Embraer para a realização da votação:

"Depois eles resolveram fazer um plebiscito, e houve muita pressão por parte da empresa que se não votassem a favor do banco de horas, muito mais trabalhadores seriam demitidos, mais de 2.000 trabalhadores. Houve também uma pressão por parte da chefia. E o próprio sindicato, daquela articulação, fazia o seu papel de 'olha, isso é bom, não vai sair muita gente..' e aí no plebiscito, dirigido e organizado por eles, acabou passando o banco de horas" (Vitor e Adriano, entrevista de pesquisa, novembro de 2011).

Os dirigentes sindicais suspeitam que houve um acordo entre os dirigentes do sindicato ligado á CUT (nessa época o sindicato ainda era regido pela forma colegiada) e a empresa:

\begin{abstract}
“Então se suspeita que houve um belo de um 'acordão' com esses caras pra poder passar e enfiar goela abaixo do trabalhador. Então o trabalhador num teve muita escolha, ele apanhou demais lá dentro, foi uma opressão muito difícil. O banco de horas só entrou devido ao trabalhador acuado, pressão da empresa, medo de demissão" (Vitor e Adriano, entrevista de pesquisa, novembro de 2011).
\end{abstract}

Após a aplicação do banco de horas, houve uma eleição sindical e esses dirigentes ligados á CUT não estavam mais presentes na direção do sindicato. A nova direção sindical que tomou posse conseguiu evitar uma nova aplicação do banco de horas na Embraer, já que o processo que levou à aplicação deste na empresa era restrito a um período de dois anos. 
3.2.5 Programa de Desligamento Voluntário (PDV), Contrato de Trabalho por Tempo

Determinado, Câmaras Setoriais, Terceirização e crítica á CUT

O Programa de Desligamento Voluntário (PDV) é outra das medidas da desregulamentação das leis do trabalho que possibilita a demissão de um grande número de trabalhadores sem um conflito significativo com estes:

"PDV é uma outra forma dos trabalhadores perderem o emprego com um impacto imediato menor. Então, eles falam o seguinte, você vai ser demitido, mas você pode ser contratado novamente, você fica tranquilo. E eu estou te dando 3 salários e mais 3 meses de convenio pra você ir embora. Fora os seus direitos. E o trabalhador vai dizer, "pô que cara legal, eu num fui demitido, e tal." Então você minimiza o impacto. Deu impacto, claro. Mas você minimiza ele. Fica tranquilo, num fala nada". (Roberto, entrevista de pesquisa, setembro de 2011).

O sindicato se posiciona como contrário ao PDV:

"Combatemos. Somos contra. Certo?! Mas existe. Na GM, nas pequenas e médias empresas nós num fazemos não, nós vamos pro enfrentamento. Mas na GM às vezes acontece, na Embraer nem tanto também. A Embraer veio com tudo, teve as 4270 demissões na crise... Nem chance de PDV teve. Foi (Tum.) porrada mesmo. Já arrebentou $50 \%$ da parte produtiva da fabrica... Que são aquelas 4200 demissões. Agora a GM é mais estática, esperta, ela usa, joga a opinião publica...". (Domingos, entrevista de pesquisa, setembro de 2011).

O Contrato de Trabalho por Tempo Determinado acaba condicionando o trabalhador na produção e não garante os direitos dos trabalhadores:

"Eles falam, você vai entrar aqui, hoje como temporário, mas lá no futuro você pode vir a ser efetivado. Então, depende só de você. Num depende mais de nada. Então o cara aceita tudo que puserem pra ele, a fim de ser um funcionário exemplar por que o cara quer é ser efetivado. Mais do que isso, não tem $40 \%$ (multa); são $2 \%$ do salário pro fundo de garantia. E se você se machucar, num tem problema pra empresa. Você num é temporário num é efetivo. Essa é a lei. Que nós tentamos derrubar no governo Lula, mas nem isso ele fez." (Roberto, entrevista de pesquisa, setembro de 2011).

De acordo com o sindicato há uma política das empresas e do governo para a aplicação do Contrato de Trabalho por Tempo Determinado: 
"O contrato por tempo determinado nós combatemos. Inclusive, tinha na GM e nós tiramos isso, quebramos! Tinha uma política, que eles exigiam que tivesse um modo de ter uma parte de $20,30 \%$ da fábrica, que seja variável, que trabalha de acordo com o mercado, tem muita produção contrata. Não tem, manda embora. E não paga os encargos. E o governo ajuda, por que num tem FGTS, num tem as multas, num tem nada, e as empresas reclamam. E nesse sentido eles chamam a gente de retrógrado, diz que nós somos ultrapassados, que não somos modernos, que várias centrais sindicais como a CUT, a Força Sindical, já evoluíram, já cresceram, já entenderam. E nós continuamos, com a cabeça reduzida, sem cérebro." (Domingos, entrevista de pesquisa, setembro de 2011).

As Câmaras Setoriais são questionadas pelo sindicato e enfrentam a resistência dos mesmos, pois eles consideram que há uma relação injusta em que une os empresários e os governos contra os trabalhadores:

\begin{abstract}
"Porque em 95 teve um grande embate das chamadas 'Câmaras Setoriais', quando a CUT começou com a 'Tripartite', O governo, os Trabalhadores e o Patrão. Se o governo e os patrões são quase a mesma coisa, os trabalhadores já estavam na desvantagem. Aí eles diziam: Grande idéia! Então todos participando na câmara do Tripartite, onde todos ganham, os trabalhadores, o patrão e o governo. Aqui num tem cabimento. Só ganha um. Se eles ganharem, nós vamos perder, não tem jeito. Então nós já começamos por ali." (Roberto, entrevista de pesquisa, setembro de 2011).
\end{abstract}

A terceirização é combatida pelo sindicato, mas ocorre de forma crescente na Chácaras Reunidas, pelo interesse dos empresários:

"Em 94, Fernando Henrique terceiriza três setores. E abre a porta pros demais. E deixa livre a correlação de força, que foi um momento muito difícil pra nós, que foi Limpeza, Portaria e Refeitório. Mas a partir daí entrou outros setores, entrou: Manuseio, Área de transporte, escritórios... Entrou uma série de questões que os patrões aproveitaram a correlação de força, classe e mais a CUT, a Força Sindical que ao invés de combater e enfrentar tudo isso de uma forma de mobilização, tentou levar isso pro Congresso, e deu no que deu. Aqui, eu diria que é um 'esquartejamento', é uma 'quarteirização'. Você tira a unidade de dentro, pega o gerente, transforma em pequenos empresários, incentiva esses caras, e tem camarada que só falta dar tiro na cabeça. Por que esses pequenos empresários, eles precarizam. (tem que ter uma explicação, de por que o cara é desse jeito, porque que ele arranca tudo que pode do trabalhador.) Por que cada dia, por exemplo, a EMBRAER, ela joga um concorrente contra o outro. Por exemplo: o Concorrente faz uma peça hoje por 'x', aí ela ( a EMBRAER) alimenta um outro Gerente, que vira um pequeno empresário pra fazer aquela peça por ' $\mathrm{x}$ 2 '. Depois ela pega aquele $\mathrm{x}-2$ e joga um contra o outro. Então ela cria uma concorrência, certo?! Decadente. Uma concorrência pra baixo. Certo?! E joga um contra o outro. E vai espremendo, e quem paga a conta é a 
molecada, são os trabalhadores". (Domingos, entrevista de pesquisa, setembro de 2011).

De acordo com o sindicato a terceirização precariza a mão de obra e fragmenta o grupo operário:

\begin{abstract}
"Essa é pior ainda. Precariza a mão de obra. Eu sou fabricante de ventiladores, só que aquela empresa embala. Então eu terceirizo. A empresa que fazer mais barato fica. Você pode fazer o movimento da terceira, se o sindicato chegar lá e tal, mas você pode ser demitido também. Então você subdivide a classe operária". (Roberto, entrevista de pesquisa, setembro de 2011).
\end{abstract}

Os dirigentes do sindicato criticam a forma como é exercida a política sindical de outras centrais sindicais, como a CUT e a Força Sindical, e denunciam um oportunismo da CUT em relação ao sindicato de São José dos Campos:

"Assim que é hoje, tanto CUT como Força Sindical também. E eles já fizeram aqui, o sindicato da CUT aqui de Taubaté, um acordo de dois anos na fábrica e colocou no acordo, 'o que SJC conquistar, vocês repassa pra nós'. Porque eles ficam livres, sabem que nós não vamos aceitar que os patrões fiquem com choradeira, sabemos que nossos economistas vão fazer os números, vão saber qual é o faturamento, o que o mercado cresceu, produtividade, a gente precisa disso pra lutar. E eles simplesmente falaram 'querem dez, então está bom, repassa dez aqui pra gente que está bom"”. (Vitor e Adriano, entrevista de pesquisa, setembro de 2011)

Para os dirigentes do sindicato, a CUT e o PT representam um retrocesso ao movimento operário e eles estão procurando construir uma nova ferramenta para os trabalhadores:

\begin{abstract}
"Então, nós estamos sofrendo um retrocesso no eixo sindical por causa da CUT, do PT, muito grande. Eles estão barrando a luta do trabalhador. Num pensa que o que está acontecendo lá fora, que o Brasil hoje, se tivesse mais direções, se tivesse uma direção igual tem a Conlutas, voltada pra classe trabalhadora, se tivesse outras centrais em apoio, pode ter certeza que esses escândalos aí já teriam explodido com o povo na rua. Só que as direções que estão aí seguram tudo isso". (Vitor e Adriano, entrevista de pesquisa, setembro de 2011).
\end{abstract}

O Sindicato dos Metalúrgicos de São José dos Campos e Região define-se como um dos mais atuantes na defesa dos trabalhadores contra os empresários, o governo federal e as 
centrais sindicais "vendidas" ao sistema. O seu posicionamento mostra-se coerente com essa definição, já que sua atuação prescreve medidas distintas das tomadas por outros sindicatos. Possui uma resistência às "medidas neoliberais", com uma mobilização significativa, que se de algum modo não as impediu todas, acatou-as de um modo que, segundo seus dirigentes, não prejudique tanto a situação do trabalhador. Uma possibilidade de estudo que esta pesquisa não pôde realizar foi verificar de modo detalhado se a representação do sindicato se converte em conquistas efetivas para os trabalhadores da base e como estes enxergam a gestão do sindicato em comparação com outros sindicatos vinculados à CUT e a Força Sindical. 


\section{CONSIDERAÇÕES FINAIS}

Do final do século XX para os tempos atuais, a aplicação de políticas neoliberais nas empresas provocou mudanças na condição operária, que dificultaram a resistência de setores mais combativos do movimento sindical contra essas medidas, uma vez que estas últimas eram introduzidas a partir da construção e conformação de um consentimento fabril, com interesses empresariais no aumento da produtividade. Os "valores neoliberais" são definidos pelos empresários como inevitáveis e universais. Não possuindo alternativas às mudanças, o trabalhador deve aderir a estes "novos valores" e ao seu novo "modo de vida" correspondente, mais flexível e instável do que no passado, ou estará "fora do jogo".

A condição operária apresentada na época em que Marx e Engels analisavam o movimento operário, quando a situação de vida era incerta para as famílias, o trabalho precário, sem direitos trabalhistas, a força de trabalho era vendida em troca de um salário que mal possibilitava a sobrevivência do trabalhador, apresenta afinidades com uma nova configuração da condição operária, uma vez que os trabalhadores do passado e de agora se assemelham na instabilidade, inconstância e imediatismo, bem como na perda de direitos trabalhistas, guardadas as devidas proporções de uma comparação histórica desse porte. Mesmo preservando uma série de direitos trabalhistas, o fato é que a nova configuração condição operária não apresenta as mesmas relativas segurança e estabilidade para os trabalhadores que figuravam no período fordista. A união dos trabalhadores também foi prejudicada e a correlação de forças neste momento histórico parece muito mais pró-capital do que anteriormente às medidas neoliberais.

A coerção largamente utilizada desde Marx até o período antecedente à nova configuração da condição operária, é empregada com menos frequência, uma vez que a própria união dos trabalhadores, sua possibilidade de ascensão e de futuro enquanto classe, se exibem com menores relevância e significância para a maior parte dos trabalhadores. Há, talvez, um trabalho muito mais amplo de construção de uma hegemonia da classe dominante, com novas estratégias para a sua conformação, em que conta mais a persuasão e conquista da classe dominada aos seus interesses e valores, do que a utilização da força e da coerção, mesmo que esses mecanismos ainda sejam utilizados nos casos considerados mais necessários. 
A PLR, o Banco de Horas e outras medidas da desregulamentação da legislação do trabalho não só auxiliaram a perda da relativa estabilidade que os trabalhadores possuíam, como também favoreceram uma mudança de perspectiva quanto ao papel desses trabalhadores dentro das empresas, uma vez que ao vincular, em maior grau, seus salários com seu rendimento e comprometimento para com as tarefas a serem executadas nas empresas, os colocou como responsáveis por sua trajetória no processo produtivo. Transmite-se, desta maneira, a imagem de que o salário depende de sua aplicação neste processo, individualizando ainda mais as relações trabalhistas e provocando a concorrência com outros trabalhadores, já que a conquista de uma remuneração superior depende das disputas estipuladas pelas empresas e a "vitória" não beneficia a todos, o que fragmenta de modo mais efetivo o grupo operário.

Como verificado nesta pesquisa, o consentimento resultante das mudanças na legislação do trabalho e de fatores mais amplos de construção e manutenção de uma hegemonia na sociedade, através da utilização de alguns instrumentos (como meios de comunicação de massa, instituições educacionais, instituições religiosas e outras que não compete aqui descrever devido à limitação desta pesquisa) tem melhor efeito sobre a organização operária quando comparado à utilização elevada da coerção. Esta configuração reflete uma mudança desfavorável na correlação de forças entre Capital e Trabalho, já que este último aparece sobrepujado por diversos fatores nas últimas décadas (situação que se inicia com as plataformas neoliberais eleitas em países centrais do capitalismo avançado e segue com seus desdobramentos, que não são aqui descritos também devido à limitação desta pesquisa). Nessa conjuntura, diversos sindicatos buscam cumprir uma agenda política que se baseia mais na barganha com os empresários do que no avanço de demandas políticas de interesse da base operária.

A construção do consentimento sobre a classe dominada pode ser favorecida por uma adaptação dessa classe às novas organizações da produção, da situação política e da conjuntura econômica, entre outros fatores relacionados, que poderiam esclarecer e explicar a baixa resistência e luta de setores do sindicalismo que historicamente exerceram uma batalha política em prol dos trabalhadores e em busca de novas conquistas, mas que atualmente pouco resistem às perdas de direitos trabalhistas. Em diversos casos não se apuram a resistência e a luta em alguns sindicatos e centrais sindicais, como ocorre no Sindicato dos Metalúrgicos de São Paulo e na Força Sindical em relação às reformas Sindical e Trabalhista. 
Com exceção de alguns sindicatos mais combativos e daqueles enormes que contam com um bom aparato sindical, a maior parte dos sindicatos parece exercer um papel "passivo" de atuação política, que varia segundo a conjuntura específica do momento e se distancia de uma atuação "ativa" e propositiva de outros sindicatos que constroem uma plataforma política e sindical que vai além do imediatismo e das tentativas de reparar as perdas dos trabalhadores.

O Sindicato dos Metalúrgicos de São José dos Campos e Região defrontou-se com essa nova conjuntura de uma maneira diferenciada em relação aos outros sindicatos filiados à CUT e à Força Sindical, atrelados ao governo federal. Os metalúrgicos de São José dos Campos procuraram fazer frente às políticas neoliberais com ações efetivas e contrárias às aplicações das medidas de desregulamentação das leis do trabalho nas empresas, com um discurso combativo ao sistema capitalista e com uma postura propositiva em relação às possibilidades de um modelo alternativo social, político e econômico.

A posição do sindicato é combativa porque promove uma luta constante em defesa dos direitos dos trabalhadores, obtendo vitórias significativas, como a que evitou a aplicação do Banco de Horas nas fábricas por ele representadas. Classista, com uma atuação coerente com os princípios de luta da classe operária contra o capitalismo e politicamente de esquerda, o sindicato luta a favor de um regime socialista e contra as medidas neoliberais, sem se submeter aos interesses do governo.

Sua estrutura sindical é inferior à de outros sindicatos (por exemplo, o Sindicato dos Metalúrgicos do ABC), o número de filiados é menor (a Apeoesp - Sindicato dos Professores do Ensino Oficial do Estado de São Paulo possui 180 mil filiados ${ }^{43}$ ), a central sindical que estão construindo (CSP-Conlutas) ainda é incipiente perto da estrutura de centrais sindicais como a CUT ou a Força Sindical e ele não possui coligações políticas com o governo federal e grupos de empresários (como fazem, respectivamente, alguns grupos da CUT e da Força Sindical).

Ainda assim, mesmo com essa "desvantagem" e com a falta de instrumentos que poderiam favorecer uma luta contra as mudanças no mundo do trabalho, ou justamente por esse motivo, de não possuir aparatos sindicais enormes e burocratizados, o sindicato enfrentou e continua enfrentando as muitas tentativas de construção do consentimento nas fábricas por eles representadas, estabelecendo uma agenda política de conscientização dos trabalhadores

\footnotetext{
${ }^{43}$ Disponível em: http://www.apeoesp.org.br/ [Acessado em junho de 2011].
} 
quanto aos avanços da patronal e propondo formas alternativas de desenvolvimento social e econômico, alcançando desta maneira significativas vitórias e vários dos objetivos políticos dos trabalhadores.

A construção do consentimento nas fábricas representadas pelo sindicato enfrentou uma oposição por parte dos seus membros em menor ou maior grau dependendo da empresa, do histórico de atuação e da militância dos operários na luta em defesa dos direitos dos trabalhadores ou por conquistas efetivas que o sindicato tenha alcançado para os mesmos.

Há uma maior dificuldade de atuação sindical em algumas empresas, como é o caso da Embraer. Seu processo de privatização, em que houve muitas demissões, a predominância de filiados à Articulação Sindical, que segundo os dirigentes do sindicato não se colocam como contrários às várias medidas da desregulamentação das leis trabalhistas, e a divisão entre engenheiros e metalúrgicos que está enraizada na estrutura da fábrica dificultam a conciliação desses setores em direção a uma luta mais efetiva contra a persuasão que a empresa exerce sobre o processo produtivo.

A chamada Chácaras Reunidas é composta por pequenas e médias empresas, fornecedoras das grandes empresas, que também apresentam condições desfavoráveis para a atuação sindical em prol dos trabalhadores, principalmente devido a grande repressão, coerção e desrespeito com que os empresários tratam seus empregados, uma vez que muitos os fazem trabalhar além da sua jornada sem receber todo o salário e sem equipamentos adequados para a sua segurança, entre outros abusos cometidos. Os dirigentes do sindicato procuram coibir estas práticas com uma atuação que obtém, em alguns casos, até a expulsão da empresa da região.

Mesmo com uma atuação firme do sindicato para conseguir o respeito para os trabalhadores por parte dos pequenos empregadores e com uma prática sindical com conquistas efetivas para a categoria, outra dificuldade enfrentada na região é a presença de muitos jovens em uma mesma empresa ${ }^{44}$ e a grande rotatividade da mão-de-obra, que dificulta a perpetuação e constituição de um repertório cultural e político próprio dos trabalhadores contra a construção do consentimento e as irregularidades cometidas pelos empresários.

\footnotetext{
${ }^{44}$ A questão não é que os jovens não possam ser militantes atuantes, mas é que essa divisão não permite a junção da experiência dos mais velhos para contribuir com o desconhecimento dos mais jovens, principalmente um desconhecimento na atuação política e referente aos seus direitos. (Ver para mais detalhes: MARTINS, 2001).
} 
A General Motors do Brasil situa-se no oposto do que foi descrito sobre a Embraer e a Chácaras Reunidas, já que o próprio sindicato designa a empresa como um bom local para a atuação sindical devido ao histórico de militância que possuem os seus trabalhadores, militantes e ativistas atuantes em praticamente todos os setores da fábrica, com conquistas do sindicato efetivadas durante décadas, o que gera uma grande confiança da base sindical em relação ao trabalho realizado pelo sindicato, assim como o apoio em confrontos decisivos para os trabalhadores, como ocorreu na campanha contra a aplicação do Banco de Horas.

Talvez seja significativo que os três principais redutos de representação do sindicato analisados pela pesquisa apresentem distinções no modo de gerenciamento das empresas e no seu tratamento aos trabalhadores, oferecendo a possibilidade de uma inferência em relação aos modelos de organização e regulação do trabalho dos últimos séculos.

A região da Chácaras Reunidas, com suas pequenas e médias empresas, exceto pelo tamanho das empresas e pela sua quantidade de funcionários, assemelha-se em alguns aspectos com a descrição que Marx e Engels esboçaram sobre a condição operária do século XIX, em que os trabalhadores sofriam significativa repressão no processo produtivo, a mão de obra possuía uma grande rotatividade e os direitos trabalhistas, por mais que fossem resguardados pelo sindicato e os operários, eram alvos constantes de desrespeito. Aqui, a disputa entre Capital e Trabalho se estabelece de forma direta, o trabalhador encontra-se frente a frente com o seu empregador e as disputas no processo produtivo se oferecem de forma praticamente imediata e sem grandes mediações.

$\mathrm{Na}$ General Motors do Brasil o empreendimento parece típico da condição operária do século XX, no qual há o predomínio do fordismo como modelo de organização social. A fábrica é gigantesca, os direitos são defendidos pelo sindicato, os trabalhadores possuem certa estabilidade, união, benefícios definidos por acordo coletivo e lutam de uma maneira mais equivalente com a patronal por melhores salários e condições de trabalho. O consentimento, embora exista e apresente influência para muitos trabalhadores, não aparenta ser a principal estratégia patronal para o aumento da produtividade e não revela uma adesão aos "valores neoliberais" pelos trabalhadores, conservando ainda uma solidariedade de classe que foi capaz de vencer a disputa com a empresa e vários setores da burguesia, como por exemplo no caso da campanha realizada contra o Banco de Horas.

Já na Embraer, o empreendimento aparenta ser um modelo da nova empresa do século XXI, de organização toyotista de trabalho, no qual, depois do processo de privatização 
e das demissões que o acompanharam, há uma grande divisão de trabalhadores, a individualização das relações trabalhistas, um aumento da concorrência interna entre os trabalhadores e a fragmentação do coletivo, tudo fomentado pela empresa. O processo de construção do consentimento com a adesão aos "valores da empresa" é mais significativo do que nas demais empresas representadas pelo sindicato, mesmo que essa construção seja amparada pela repressão e o medo advindo das demissões e punições que podem ser praticadas pela empresa.

A Embraer assemelha-se a um modelo ideal para os empresários de como deve ser a empresa do século XXI, em que a receita conta com um processo constante de construção e conformação dos "valores neoliberais" (como a flexibilidade, rapidez, mobilidade da força de trabalho, do capital e outros valores). A adesão a esses valores pelos "colaboradores" alia-se a medidas tayloristas no processo produtivo, bem como a repressão e a opressão sobre os trabalhadores é notada quando a adesão não estiver dando conta de aumentar a produtividade dos trabalhadores.

O Sindicato dos Metalúrgicos de São José dos Campos e Região convive e desdobrase para atender as reivindicações dos trabalhadores em três "modelos" distintos de empresas, em uma mesma região. Mesmo assim, sua atuação afirma-se como em prol da base do sindicato, através de um processo de conscientização dos trabalhadores quanto a sua situação e as possibilidades de futuro em outra forma de organização social, adotando medidas diferenciadas em comparação com outros sindicatos, como o fim do salário do dirigente sindical pago pela categoria, com o intuito de evitar a acomodação dos dirigentes e a burocratização derivada.

Em relação à PLR, o sindicato reconhece que ao aceitar a discussão sobre as metas para a remuneração dos trabalhadores, automaticamente está participando do "jogo" com a empresa, mesmo com o estabelecimento do pagamento sem divisões por setor/equipes da fábrica ou por cargos da empresa e, portanto, sem divisões no valor a ser pago pela PLR. Atuam postulando a inexistência de metas para a concretização da PLR, ou em alguns casos de uma meta única para toda a empresa, embora enfrentem algumas dificuldades dependendo da empresa e da sua forma de negociação com os trabalhadores. O sindicato trava uma luta por um valor alto de PLR sem perder de vista a campanha salarial da categoria, afirmando que o objetivo mais importante é o aumento de salário fixo. Deste modo, o sindicato postula uma 
adesão crítica a essa medida, porém sofre com a base dos trabalhadores que tem muito interesse pela medida, particularmente por seu alto valor pago em uma ou duas vezes no ano.

O sindicato manteve-se contrário ao Banco de Horas mesmo com uma ampla campanha de diversos setores interessados na aplicação desta medida: a General Motors do Brasil, prefeito, vereadores, empresários, e alguns setores da imprensa. Realizou uma série de atos no intuito de mobilizar e conscientizar a categoria contra o avanço destes setores empresariais, obtendo uma vitória significativa para os trabalhadores tendo em vista os oponentes que o sindicato enfrentou. Em relação às outras "medidas neoliberais" (Contrato de Trabalho por Tempo Determinado, Programa de Desligamento Voluntário, Terceirização e etc.), o sindicato desempenha uma resistência efetiva com uma mobilização significativa, procurando barrá-las todas ou, caso não seja possível, tentando adaptá-las de uma forma que não prejudique tanto a situação do trabalhador.

O Sindicato dos Metalúrgicos de São José dos Campos e Região representa uma contra-hegemonia no sentido gramsciano, já que sua atuação é contrária ao horizonte ideológico dessa época, que prescreve uma nova configuração da condição operária correlata com o domínio do neoliberalismo nas relações econômicas e políticas, flexibilidade e instabilidade nas relações de trabalho.

Se essa resistência está ligada a uma circunstância específica ou conjuntura política passageira, que logo após um período poderá desaparecer e o sindicato terá que aderir às políticas neoliberais, não há como inferir considerações significativas. $O$ fato de grande relevância é que pelos dados coletados junto à representação do sindicato para essa pesquisa, entende-se que essa resistência é possível e é realizada pelo sindicato. Ainda que obviamente pequeno quando comparado ao aparato e à consolidação mundial de seu oponente, o sindicato constitui uma contra-hegemonia fundamental para o combate ao avanço de políticas neoliberais e representa um pólo de resistência para outros sindicatos que pretendam atingir os mesmos objetivos. 


\section{REFERÊNCIAS}

AGLIETTA, Michel. A Theory of capitalist Regulation: The US Experience. Londres: NLB, 1979.

ANTUNES, Ricardo. Adeus ao Trabalho?: Ensaio sobre as Metamorfoses e a Centralidade do Mundo do Trabalho. São Paulo: Cortez/Unicamp, 1995.

Os Sentidos do trabalho: ensaio sobre a afirmação e a negação do trabalho. São Paulo: Boitempo, 1999.

Neoliberalismo, Trabalho e Sindicatos: Reestruturação Produtiva no Brasil e na Inglaterra. 2. ed., São Paulo: Boitempo, 1998.

ALVES, Giovanni. Reestruturação Produtiva e a Crise do Sindicalismo no Brasil. Tese de Doutorado, Campinas: IFCH/UNICAMP, 1998.

ARAÚJO, Ângela M. Carneiro; CARTONI, Daniela M.; JUSTO, Carolina R. D. Mello. Reestruturação Produtiva e negociação coletiva nos anos 90. Revista Brasileira de Ciências Sociais. [S.1.] Associação Nacional de Pós-graduação em Ciências Sociais (ANPOCS), v. 16, n. 45, p. 85-112, fev. 2001.

ARBIX, Glauco. Falsos Passaportes Para a Modernidade: o Governo e as Relações Trabalhistas. Pesquisas, São Paulo, n. 10, p. 21-37, 1998.

Uma Aposta no Futuro. Os Primeiros Anos da Câmara Setorial da

Indústria Automobilística. 1. ed. São Paulo: Scritta, 1996.

ARBIX, Glauco e ZILBOVICIUS, Mauro (org.). De JK a FHC, a reinvenção dos carros. São Paulo: Scritta, 1997.

BALCÃO, N. F.. Terceirização: a desmontagem do contrato de trabalho. São Paulo: Dissertação (Mestrado em Sociologia). Faculdade de Filosofia, Letras e Ciências Humanas, Universidade de São Paulo, 2000.

BARROS, Cássio Mesquita. Flexibilização do Direito do Trabalho. Revista LTR. vol. 59, n.8, agosto, 1995. p. 1034-1045.

BEAUD, S. \& PIALOUX, M. "Etnografia operária e sociologia: A composição de uma equipe”. In: ENCREVÉ, P. \& LAGRAVE R. -M. Trabalhar com Bourdieu. São Paulo: Bertand Brasil, 2005.

Retorno à condição operária: Investigações em fábricas da Peugeot na

França. São Paulo: Boitempo, 2009. 
BEDÊ, Marco Aurélio. A Indústria Automobilística no Brasil nos anos 90. Tese de doutorado apresentada à Faculdade de Economia, Administração e Contabilidade da Universidade de São Paulo, 1996.

BIANCHI, A. ; BRAGA, R.. 1968 e depois: os estudantes e a condição operária. Outubro (São Paulo), v. 10, p. 15-40, 2008.

BOITO JR., Armando. "Neoliberalismo e corporativismo de Estado no Brasil". In: ARAÚJO, Ângela M. Do corporativismo ao neoliberalismo: Estado e trabalhadores no Brasil e na Inglaterra. São Paulo: Boitempo, 2002.

. O sindicalismo de Estado no Brasil: uma análise crítica da estrutura sindical. São Paulo: Hucitec, 1991.

. Política Neoliberal e o sindicalismo no Brasil. São Paulo: Xamã, 1999.

BOURDIEU, Pierre. A Miséria do mundo. Rio de Janeiro: Vozes, 1987.

BRAGA, Ruy. A nostalgia do fordismo. São Paulo: Xamã, 2003.

. Mediações institucionais e inovações metodológicas: A teoria da regulação e a formalização da dinâmica econômica histórica. Sociedade e Estado, Brasília, v. XVII, n. 2, 2004.

. Uma sociologia da condição proletária contemporânea. Tempo Social. Revista de Sociologia da USP, São Paulo, v. 18, n. 1, p. 133-152, 2006.

BRAVERMAN, Harry. Trabalho e Capital Monopolista: a degradação do trabalho no século XX. Tradução de Nathanael C. Caxeiro, Rio de Janeiro: Zahar, 1977.

BRESCIANI, Luís Paulo. Flexibilidade e reestruturação: o trabalho na encruzilhada. Apresentado ao XX Encontro Nacional da ANPOCS, Caxambu, 1996.

BURAWOY, Michael. A transformação dos regimes fabris no capitalismo avançado. Revista Brasileira de Ciências Sociais. São Paulo: v. 5, n.. 13, 1990.

Manufacturing consent. Changes in the labor process under monopoly capitalism. Chicago: University of Chicago Press, 1982.

CAMARGO, José Márcio de (org.). Flexibilidade do Mercado de Trabalho no Brasil. Rio de Janeiro: Fundação Getúlio Vargas Editora, 1996.

CARDOSO, Adalberto Moreira. A construção da sociedade do trabalho no Brasil: Uma investigação sobre a persistência secular das desigualdades. Rio de Janeiro: Editora FGV, 2010. 
. A década neoliberal e a crise dos sindicatos no Brasil. São Paulo: Boitempo, 2003

CARDOSO, Ana Cláudia M. Emprego: estratégias e ação sindical nos anos 90, o caso dos metalúrgicos de São Paulo. Dissertação (Mestrado em Sociologia) - Universidade de São Paulo, São Paulo, 1998. Tempo de Trabalho, Tempo de Não Trabalho: vivências cotidianas de trabalhadores. Dissertação (Doutorado em Sociologia) - Universidade de São Paulo, São Paulo, 2007.

CARDOSO JR., José Celso. Crise e desregulação do trabalho no Brasil. Tempo Social, Revista de Sociologia da USP. São Paulo: 31-59, novembro de 2001.

CASTEL, Robert. As Metamorfoses da Questão Salarial. Rio de Janeiro: Vozes, 1998.

CASTELLS, Manuel. Fim do Milênio. São Paulo: Paz e Terra, vol. III, 1999.

CASTILLO, Juan J. Sociologia del trabajo. Madri: CIS, 1996.

CASTRO, Nadya A. (org.). A Máquina e o Equilibrista: Inovações na indústria automobilística Brasileira. São Paulo: Paz e Terra, 1995. . Modernização e trabalho no complexo automotivo brasileiro: reestruturação industrial ou japonização de ocasião?. Novos Estudos. CEBRAP, São Paulo, v. 37, p. 155-173, 1993. . "Reestruturação produtiva, novas institucionalidades e negociação da flexibilidade”. São Paulo em Perspectiva, São Paulo: vol. 11, n. 1, 1997, p. 3-8.

CASTRO, Nadya A. \& COMIN, Álvaro A.. “As Novas Esferas de Regulação do Trabalho e o dilema sindical”. São Paulo em perspectiva, São Paulo, v. 12, n. 1, 1998. p. 45-52.

CASTRO, Nadya A. \& GUIMARÃES, Antônio S. A.. "Além de Braverman, depois de Burawoy: vertentes analíticas na sociologia do trabalho." Revista Brasileira de Ciências Sociais, São Paulo, n. 17, 1991.

CHESNAIS, François. A Mundialização do Capital. São Paulo: Xamã, 1996.

CHESNAIS, François. (org.). A Mundialização financeira: gênese, custos e riscos. São Paulo: Xamã, 1999.

COMIN, A. A.. Desregulação do mercado de trabalho e sindicato. In: D’INCAO, Maria Angela. (Org.). O Brasil não é mais aquele... Mudanças sociais após a redemocratização. São Paulo: Cortez, 2001, p. 247-272. 
COMIN, A. A. (org.); OLIVEIRA, F. (org.). Os cavaleiros do anti-apocalipse: Reestruturação Produtiva e Novos Padrões nas Relações Capital-Trabalho na Indústria Automobilística. São Paulo: Entrelinhas, 1999.

CORIAT, Benjamin. Pensar pelo avesso: o modelo japonês de trabalho e organização. Rio de Janeiro: Revan/UFRJ, 1994.

CORREIA, Expedito de Carvalho. Experiências de reestruturação produtiva na indústria automobilística e aeronáutica no Vale do Paraíba (SP). São Paulo: Dissertação (Doutorado em História econômica). Faculdade de Filosofia, Letras e Ciências Humanas, Universidade de São Paulo, 2003.

COUTROT, T. Organização do trabalho e financeirização das empresas: a experiência européia. Revista Outubro, São Paulo, n. 12, p. 33-43, 2005.

DIEESE (org.). Trabalho e abordagem pluridisciplinar: estudos Brasil, França e Argentina. São Paulo: DIEESE; Campinas: CESIT/IE/UNICAMP, 2005. p. 7-33. Um balanço da participação dos trabalhadores nos lucros e resultados das empresas. São Paulo: DIESSE, 2000.

DRUCK, Maria da Graça. Terceirização: (des) fordizando a fábrica: um estudo do complexo petroquímico. São Paulo, EDUFBA/ Boitempo, 1999.

DUBAR, Claude. A crise das identidades: A interpretação de uma mutação. São Paulo: EDUSP, 2009.

DUMÉNIL, G.; LÉVY, D. Capital Resurgent. The roots of the neoliberal revolution. Havard: Havard University, 2004.

ENGELS, Friedrich. A situação da classe trabalhadora na Inglaterra. São Paulo: Global, 1985.

FERRAZ, Ana Lúcia Marques Camargo. Dramaturgias da autonomia. São Paulo: Perspectiva, 2009.

FERREIRA, Cândido Guerra. O fordismo, sua crise e o caso brasileiro. Campinas: IE/UNICAMP, 1993. (Cadernos do CESIT, texto n. 13).

FERREIRA, Leila da Costa. (org.). A Sociologia no Horizonte do Século XXI. São Paulo: Boitempo, 1997.

FIGUEIREDO, Mariana Leite. Uma alternativa sindical? A negação do "propositismo" no sindicalismo metalúrgico paulista. Campinas: Dissertação de mestrado, IFCH/UNICAMP, 2007. 
FRANCA, G. C.. O espaço de trabalho a partir das transformações na fábrica. São Paulo: Dissertação (Mestrado em Geografia Humana). Faculdade de Filosofia, Letras e Ciências Humanas, Universidade de São Paulo, 2004.

FREDERICO, Celso. Crise do socialismo e movimento operário. São Paulo: Cortez, 1994.

GALVÃO, Andréa. Neoliberalismo e reforma trabalhista no Brasil. Campinas: Dissertação de Doutorado, IFCH/UNICAMP, 2003.

Participação e Fragmentação: A Prática Sindical dos Metalúrgicos do ABC. Campinas: Dissertação de Mestrado, IFCH/UNICAMP, 1996.

GITAHY, Leda; BRESCIANI, Luís Paulo. Reestruturação produtiva e trabalho na indústria automobilística brasileira. Campinas: DPCT/IG/UNICAMP, jul. 1997. Mimeografado.

GORENDER, Jacob. Globalização, Tecnologia e Relações de Trabalho. São Paulo: Estudos Avançados, IEA-USP, 1997.

GORZ, A. O imaterial. São Paulo: Annablume, 2005.

GOUNET, Thomas. Fordismo e toyotismo na civilização do automóvel. São Paulo: Boitempo, 1999

GRAMSCI, Antonio. Americanismo e fordismo. In: GRAMSCI, Antonio. Maquiavel, a política e o Estado moderno. 8. ed. Tradução de Luiz Mário Gazzaneo. Rio de Janeiro: Civilização Brasileira, 1990.

GUIMARÃES, N. A.; COMIN, A. A.. A alquimia organizacional: qualificação e construção do consentimento. Tempo Social. Revista de Sociologia da USP, São Paulo, v. 10, n. 2, p. 113-144, 1998.

HARVEY, David. A condição pós-moderna. São Paulo: Loyola, 1992.

HIRATA, Helena Sumiko (org.). Sobre o "modelo" japonês: automatização, novas formas de organização e de relações de trabalho. São Paulo: EDUSP, 1993.

IANNI, Octávio. A Era do Globalismo. Rio de Janeiro: Civilização Brasileira, 1996.

JATOBA, Jorge e ANDRADE, Everaldo G. Lopes. A Desregulamentação do Mercado e das Relações de Trabalho no Brasil: potencial e limitações. Brasília: IPEA, 1993.

KREIN, J. D. Tendências recentes nas relações de emprego no Brasil. Campinas: Dissertação de Doutorado, IFCH/UNICAMP, 2007. 
KREIN, J. D.; SANCHES, A. T. PLR: um balanço das experiências cutistas. Debates \& Reflexões 12. São Paulo: Escola Sindical São Paulo- Friedrich Ebert Stiftung- CUT Brasil. 2004.

LAZARRATO, M. \& NEGRI, A. Trabalho Imaterial. Rio de Janeiro: DP\&A, 2001.

LESSA, Sérgio. Mundo dos homens: trabalho e ser social. São Paulo: Editempo Editorial, 2002.

LIMA, Eurenice. A construção da obediência. Campinas: Dissertação de Mestrado, IFCH/UNICAMP, 1996.

LINHART, Daniele. A desmedida do capital. São Paulo: Boitempo, 2007.

LIPIETZ, A. Miragens e Milagres. Problemas da Industrialização do Terceiro Mundo. São Paulo, Nobel, 1988.

LOJKINE, Jean. A revolução informacional. São Paulo: Cortez, 1995.

LOPES, Juarez Brandão. Crise do Brasil arcaico. São Paulo: Difel, 1967.

LÖWY, Michael. A teoria da revolução no jovem Marx. Petrópolis: Vozes, 2002.

MANDEL, Ernest. O capitalismo tardio. São Paulo: Abril Cultural, 1982.

MARCELINO, Paula Regina Perreira. A logística da precarização: terceirização do trabalho na Honda do Brasil. Campinas: Dissertação (mestrado) - Instituto de Filosofia e Ciências Humanas da Universidade Estadual de Campinas, 2002.

MARTINS, Heloísa H. T. de S. O processo de reestruturação produtiva e o jovem trabalhador: conhecimento e participação. Tempo Social. Revista de Sociologia da USP. São Paulo, vol. 13, n. 2, nov. 2001. p. 61-87.

MATtoso, J. E. L. e OLIVEIRA, Carlos A. B. (org.). Crise e trabalho no Brasil: modernidade ou volta ao passado? 2 ed. São Paulo: Scritta, 1996.

MÉSZÁROS, István. O desafio e o fardo do tempo histórico. São Paulo: Boitempo, 2007.

MELLO E SILVA, Leonardo. A organização sindical face aos novos paradigmas de organização do trabalho. Ariús (UFPB), v. 13, p. 34-40, 2007a.

. Trabalho em grupo e sociabilidade privada. São Paulo: Ed. 34, 2004.

Trabalho e sociabilidade privada: a exclusão do outro. Um olhar a partir das células de produção. Revista Brasileira de Ciências Sociais, São Paulo/Bauru, v. 21, n. 61, p. 147-161, 2006. 
MOURA, Marcela Medeiros. Discurso e prática dos metalúrgicos do Estado de São Paulo. Campinas: Dissertação (Mestrado em Sociologia). Universidade Estadual de Campinas, 2011.

NASCIMENTO, B. H.. Formação da Indústria Automobilística Brasileira.. 1ª ed. USP SAO PAULO: IGEOG-USP, 1976.

NAVES, Rosinei A.. A General Motors no Mercosul na década de 90: transformações produtivas em um bloco comercial periférico. São Paulo: Dissertação (Integração da América Latina) Prolam, USP, 2002.

NORONHA, Eduardo gorenti. O Modelo legislado de relações de trabalho e seus espaços normativos. São Paulo: Tese de Doutorado, Depto. De Ciência Política, USP, 1998.

OLIVEIRA, Carlos Alonso de (org.). O mundo do trabalho: crise e mudança no final do século. São Paulo: Ed. Página Aberta; Scritta, 1994. (Projeto Mercado de Trabalho, Sindicatos e Contrato Coletivo, MTb/PNUD, CESIT/IE/UNICAMP, FECAMP).

OLIVEIRA, F.; BRAGA, Ruy.; RIZEK, C. S.. (Org.) Hegemonia ás avessas. São Paulo: Boitempo, 2010

OLIVEIRA, F.; RIZEK, Cibele S.. (Org.). A Era da Indeterminação. 1 ed. São Paulo: Boitempo, 2007.

PEREIRA, G. R.. Transformação da identidade operária. Redd -Revista Espaço de dialogo e desconexão, v. v2, p.05, 2009.

PINTO, Geraldo Augusto. A organização do trabalho no século 20: Taylorismo, fordismo e toyotismo. São Paulo: Expressão Popular, 2010.

- Reestruturação produtiva e organização do trabalho na indústria de autopeças no Brasil. Campinas: Dissertação (mestrado) - Instituto de Filosofia e Ciências Humanas da Universidade Estadual de Campinas, 2003.

PIRES, Álvaro P. Sobre algumas questões epistemológicas de uma metodologia geral para as ciências sociais. In: VVAA. A pesquisa qualitativa: enfoques epistemológicos e metodológicos. Petrópolis: Vozes, 2008.

POCHMANN, M. A desestruturação do mercado de trabalho nos anos 90. Campinas: CESIT/IE/UNICAMP, 1998.

POCHMANN, M. ; MORETTO, Amilton . Reforma Trabalhista: A Experiência Internacional e o Caso Brasileiro. Cadernos ADENAUER (São Paulo), São Paulo, v. III, n. 02, p. 69-90, 2002. 
RAMALHO, José Ricardo e MARTINS, Heloísa (org.). Terceirização: diversidade e negociação no mundo do trabalho. São Paulo: Hucitec/Nets-Cedi, 1994.

RIFKIN, Jeremy. O Fim dos Empregos. São Paulo: Makron Books, 1995.

RODRIGUES, Iram J.. O novo sindicalismo - vinte anos depois. Rio de Janeiro: Vozes, 1999.

.Reestruturação produtiva e ação sindical: dilemas do sindicalismo brasileiro nos anos 90. Caxambu: $19^{\circ}$ Encontro da ANPOCS [Trabalho apresentado], 1995.

. Trabalhadores em empresas automobilísticas: um estudo de caso. Revista de Direito do Trabalho (São Paulo), v. 125, p. 98-114, 2007.

RODRIGUES, Leôncio Martins. Destino do Sindicalismo. São Paulo: EDUSP, FAPESP, 2002.

Partidos e Sindicatos: ensaios de sociologia política. São Paulo: Ática, 1990.

SALlUM Jr., Brasilio. Classes, cultura e ação coletiva. Lua Nova. Revista de Cultura e Política, São Paulo, v. 65, p. 11-42, 2005. - Metamorfoses do Estado no final do século XX. Revista Brasileira de Ciências Sociais, São Paulo, v. 18, n. 52, p. 35-55, 2003.

SENNETT, Richard. A corrosão do caráter. São Paulo: Editora Record, 1999.

SILVA, Cristiane A. Fernandes da. A gestão de si na reinvenção das normas: práticas e subjetividades no trabalho. São Paulo: Dissertação (Doutorado em Sociologia). Faculdade de Filosofia, Letras e Ciências Humanas, Universidade de São Paulo, 2007.

SILVA, Elisabeth Bortolaia. Refazendo a fábrica fordista. Contrastes da indústria automobilística no Brasil e na Grã-Bretanha. São Paulo: HUCITEC-FAPESP, 1991.

SILVA, Fabio P. M.. Trabalho e emprego no setor de telemarketing. São Paulo: Dissertação (Mestrado em Sociologia) Faculdade de Filosofia, Letras e Ciências Humanas, Universidade de São Paulo, 2010.

TELlES, Vera S.. (org.). Sociologia da Condição Operária. Tempo Social, Revista de Sociologia da USP. São Paulo: 2006.

THIOLLENT, Michel. Crítica metodológica, investigação sociológica e enquête operária. 3.ed. São Paulo: Polis, 1982.

THOMPSON, E.. Formação da Classe Operária Inglesa. São Paulo: Paz e Terra, 1987. 
WEIL, Simone. A condição operária e outros estudos sobre opressão. Tradução de Therezinha G. G. Langlada, seleção e apresentação de Ecléa Bosi. Rio de Janeiro: Paz e Terra, 1979. (Coleção O Mundo, hoje; v. 32).

WOOD, Stephen. O modelo japonês em debate: Pós-fordismo ou japonização do fordismo. Revista Brasileira de Ciências Sociais, ano 6, outubro de 1991.

\section{Sites:}

APEOESP. Sindicato dos Professores do Ensino Oficial do Estado de São Paulo. Disponível em: http://www.apeoesp.org.br/ [Acessado em junho de 2011].

SINDMETALSJC. Sindicato dos metalúrgicos de São José dos Campos. Disponível em: http://www.sindmetalsjc.org.br [Acessado em junho de 2011]. 


\section{Apêndice - Roteiro Básico das Entrevistas}

1. Qual a opinião do sindicato sobre as medidas aplicadas na década de 1990 que modificaram as condições de vida dos trabalhadores?

2. Qual a posição do sindicato quanto à participação nos lucros e resultados (PLR)?

3. O sindicato participa das decisões envolvendo as metas para o cumprimento da PLR?

4. O sindicato participa das decisões nas fábricas?

5. O que o sindicato considera mais importante a PLR ou a campanha salarial da categoria? Por quê?

6. Como funcionava antes da aplicação da PLR?

7. Qual a posição do sindicato em relação ao banco de horas?

8. Como funcionava antes da aplicação do banco de horas em algumas fábricas?

9. Você, enquanto representante do sindicato, acredita que houve uma mudança na fábrica com a PLR e o banco de horas?

10. O que o sindicato acha das metas a serem atingidas para ganhar a PLR?

11. O sindicato tem participação efetiva na definição destas metas?

12. Acredita que o sindicato é importante para a conquista da PLR?

13. O que recebe mais atenção dos trabalhadores a PLR ou a campanha salarial?

14. O que acha do banco de horas? Prefere o pagamento de horas-extras ou o banco de horas?

15. Na opinião do sindicato, as metas pela PLR intensificaram a concorrência entre os próprios trabalhadores?

16. Os trabalhadores sofrem muitas cobranças no ambiente de trabalho? De que forma isso se estabelece?

17. As fábricas organizaram os trabalhadores em equipes de trabalho? Essas equipes competem entre si?

18. As metas modificaram as relações entre os trabalhadores?

19. Essa nova organização do trabalho afetou a militância/atuação dos trabalhadores junto ao sindicato?

20. As empresas e a gerência procuram afastar os trabalhadores do sindicato? Em que medida?

21. Quais as estratégias/táticas que a patronal utiliza para afastar os trabalhadores do sindicato? 
22. Quais as estratégias/táticas que as empresas utilizam para aumentar a produtividade dos operários?

23. Como o sindicato se posiciona diante dos ataques da gerência?

24. Os trabalhadores aderem/aderiram às mudanças nas organizações das empresas?

25. Houve conflitos/resistências especificas dos trabalhadores, sem a participação do sindicato?

26. Se houve, como o sindicato procurou canalizar as insatisfações dos trabalhadores?

27. Como o sindicato enxerga a sua atuação junto aos trabalhadores que representa?

28. A base sindical é mobilizada/atuante?

29. Na opinião do sindicato a base aprova as pautas/reivindicações da diretoria do sindicato?

30. Como funciona a estrutura sindical desse sindicato?

31. Como a diretoria enxerga as correntes políticas que disputam as gestões no sindicato?

32. Qual a opinião do sindicato sobre a CUT? E a Força Sindical?

33. Qual o papel do sindicato na construção da CSP- Conlutas?

34. Como o sindicato enxerga a atuação da CSP- Conlutas? O que o sindicato enxerga de possibilidades futuras para a CSP- Conlutas?

35. Para finalizar, na opinião do sindicato dos Metalúrgicos de São José dos Campos, qual deve ser o papel de um sindicato e uma central sindical no cotidiano dos trabalhadores? 